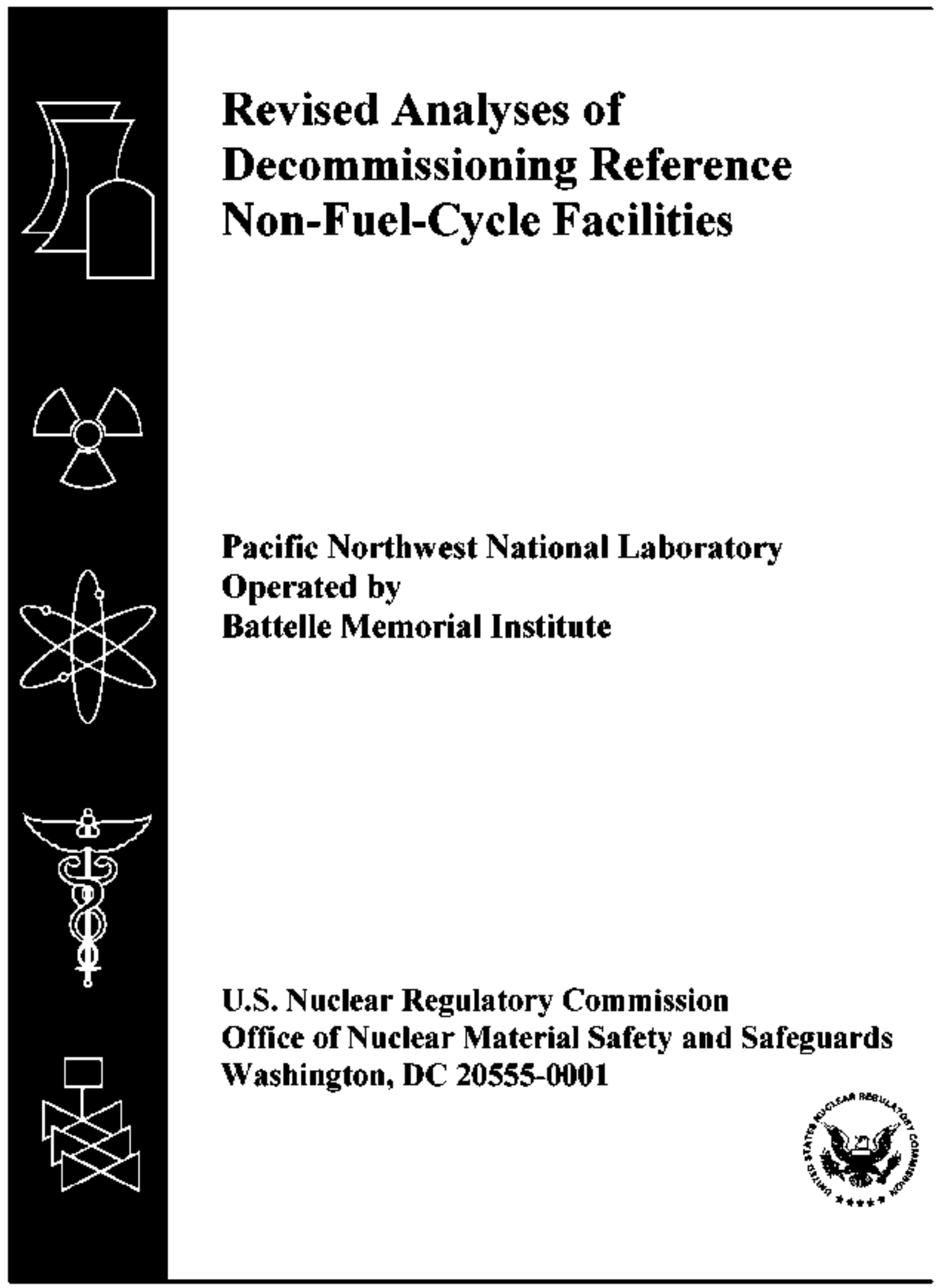




\section{AVAILABILITY OF REFERENCE MATERIALS}

IN NRC PUBLICATIONS

MRC Reforence Materal

As of November 1999, you may electron|cally access NUREG-series publications and clher NRC records at NRC's Public Electronic Reatipg Room al hno thumw nrc govireading-m himl. Publicly released records includte, to name a few, NUREG-series pulbteations; Foderal Register notices; applicant, licensee, and vendor documents and correspondencer; NRC correspondenics and tintem memoranda; bulketins and information notices; inspection and investigalive reports; licensee event reports; and Comuntssion papers and thent attachments.

NRC pubEcations in the NUREO series, NRC regulations, and Title 10, Energy, in the Code of Foderal Regutattons may also be purchased from one of thesse two sources.

1. The Supenintendert of Docturients

U.8. Govemrient Printing Otfics

Mail Stop SSOP

Washington, DC 20402-0001

Internel: bookslore.gpo.gow

Tolephone: 202-512-1800

Fax: 202-512.2250

2. The National Techrical Information Serwice Springfietd, VA 22161-0002

vantintis oor

1-600-553-6847 or, locally, 703-605-6000

A single copy ol each NRC dralt report for comment is avatable free, to the extent of supply, upon wolten requenst as follows:

Address: Office of the Chief thformation Oflicer. Reproduction and Oistribution Services Section

U.S. Nuclear Regulalony Commission Washungton, DC 20555-0001

E-mal: DISTRIBUTIONanre gow

Facsimine: 301-415-22a9

Some publicalions in the NUREG series that are posled at NRC's Web ste address htip /iwnw nic govireading-rmidoc-collectionsfnuregs are updated perodically and may dofter from the last printed version. Athough refergnces to malerlal found on a Web stle bear the date the material was accersed, the material avalable on the date elted may subsequently be renoved fram the ste.
Non-Nic Reforence Materlal

Oocuments grailable trom oublic and special technical abrarles trclude all open hterature items, such as books, joumal articl bs, and transactions, Fenderal Aegistar notices, Federal and State legislation, and congressionat reports. Such documents as theses, dissertations, foreign reports and translations, and non-NRC comference proceedings may be purchased from their sponsoring organization.

Copies of industry codes and slandards used in a substanitwe manner In the NRG regulatory process are mainialned at-

The NRC Tectnical Library

Two While Flutt North

19545 Rockwlla Pike

Rockvile, MO 20B82-2738

These slandards are eyzilable In the threry for reference use by the public. Codes and standards are usually copyrighted and may be purctiased from the onginating organization or, if they are American National Standards, from-

American Nalional Standards Inshlute 1) West 42"st Street

New York, NY 10,0136-B002

wim.ansiorg

$212-642-4900$

Legally bindring regulatory requitements are stated only in laws; NRC regtulations; ficenses, inctuding techniral spetifications; or onders, not in NUREG-series publtcations. The viows expressed In contractor-prepared pub-licabons in this series are not necessarily those of the NRC.

The NUREG series comprises (1) technical and administratlve reports and books prepared by the stafi (NURE $3-X \times X X)$ or agentry contractors (NUREGICR-XXCX), (2) proceedings of conferences (NUREG/CP- $\times X \times X)$ ), (3) reports rosuliting from inlemational agreements (NUREGNA-XXXX), (4) brochures (NUREGBR-XXXX), and (5) compibalions of legal dedsiens and orders of the Commlssion and Atomic and Safoty Licensing Boards and of Directors' declsions under Section 2,206 of NRC's regulations (NUREG-0750).

DISCLAMER; This report was prepared as an accotint of work sponsored by an agency of the U.S. Govemment. Nerther the U.S. Govenment nor ary agency thereot, nor any employee, makes any waranty, expressed or inpled, or assumes any legal liability or responsibility for any third party's use, or the results of such use, of any informalion, apparatus, product, or process disclosed in this publcation, or represents that its use by such thtrd party would not iniringe privately owned rights. 
NUREG/CR-6477

PNNL-11209

\section{Revised Analyses of \\ Decommissioning Reference Non-Fuel-Cycle Facilities}

Manuscript Completed: October 1997

Date Published: December 2002

Prepared by

M. C. Bierschbach, D. R. Haffner,

K. J. Schneider, S. M. Short

Pacific Northwest National Laboratory

Richland, WA 99352

C. W. Prichard, NRC Project Manager

Prepared for

Division of Industrial and Medical Nuclear Safety

Office of Nuclear Material Safety and Safeguards

U.S. Nuclear Regulatory Commission

Washington, DC 20555-0001

NRC Job Code L2025

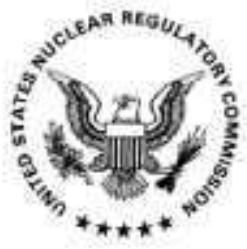




\begin{abstract}
the same as in the original study and include:
- a labcratory for the manufacture of 'H-Jabeled compounds

- a laborntory for the marnifacture of ${ }^{\text {tht }}$ C-labeled comporuxds

- a laboratory for the manufaciure of try-labeled compotrids

- a laboratory for the manufacture of ${ }^{\mathrm{m}} \mathrm{Cs}$ sealod sources

- a laboratory for the minufacture of ${ }^{241}$ Am gealed saurces

- an instilutional oser lakporatory.
\end{abstract}

Abstract

Cost information is developed for the conceptual decornnissioning of non-fuel-cycle nuclear factlities that represent a significant decomprissioning lask in terms of decontamination and disposal activities. This study is a re-evaluation of the original study (NUREG/CR-1754 and NUREG/CR-1754, Addendum 1). The reference facilities examined in this sudy are

In addition to the laboratories, three reference siles that require some decommissioning effort were also exarnined. These sites are:

- a site with a contaminated drain Jine and hold+up tank

- a site with a contaninated grourd surface

+ a trilings pile containing wanium and thariusn residues.

Decommissioning of these reference facilities and sites can be accornplished using teckniques and equipment that are in common industrial use. Essertially the same technology assumed in the original study is used in this sudy.

For the reference laboratory-type farilities, the sludy approsch is to first evaluate the deconmmissioning of individual pompopents (e.e. fume hoods, glove boxes, and building rurfaces) that are common to many laboxatory factlitits. The information oblained from analyzing the individual components of each facility are then used 10 determine the cost, manpower requirements and dose information for the decommissioning of the entite facility. DECON, the objective of the 1988 Rutenaking for materials facilities, is the decomrnissioning allemative evaluated for the reference labortories because it results in the release of the facilicy for restrietued ar unrestricted use as soon as possible. For a facility. DECON requires that contartinated components either be: 1) decontaminated to restricted or unrestricted release levels or 2) packaged and shipped to an authorized disposal site. This study considers unrestricted release only. The new deconcrissioning criteria of July 1997 are too rcoent for unis study to include a cost analysis of the restricted release option, which is now allowed under these new criteria.

The costs of decommissioning tacility components are genteally estimited to be in the range of $\$ 140 \mathrm{w} \$ 27,000$, depending on the type of component, the type and amaunt of radidactive contamination, the remediation options chosen, and the quantity of radiaxctive waste generated from decommissionting operations. Estimated costs for decommissioning the example laboratories range from $\$ 130,000$ to $\$ 205,000$, stsuning aggressive low-level waste (L.LW) volume reduction. If only aúnimal LLW volume reduction is employed, decommissioning costs range from $\$ 150,000$ to $\$ 270,000$ for these laboratories. On the basis of estimated decommissioning costs for facility components, the costs of decommissioning typical 
Jon-fuel-cycle laboranory facilities are estimated to range from about \$25,000 for the decommissioning of a \$mall noors containing one or twa fume hoods 10 more than $\mathbf{\$} !$ million for the decomunissioning of an industrial planl containing several laboratories it which radiochemicals and sealed radionctive saurces are prepared.

For the reftrence sites of this study, the besic decommissioning altematives are: (J) site stabilization follewed by long-term care and (2) removal of the waste or contaminated soil to an authorized disposat site. Cost estimates made for decommisstoning three reference sites range from about $\$ \mathbf{\$ 3 0 , 0 0 0}$ for the removal of a contaminated drain line and bold-up tank to more than $\mathbf{\$ 2 3}$ million for the renoval of a tailings pile that contains radioactive residue from ore-processing operations in which tin slag is prosessed for the recovery of rare metals.

Total occupational radiation doses generally range from 0.00067 person-rem to 13 person-rem for decominissioning the laboratory facilities of this study.

The results of this study are: (I) decorrnissioning cosis have contigued to increase since publication of the original study, due primarily to raptdly escalating costs for disposal of tadioactive wastes at the available LLW burial sites; (2) these swifly increasing $U W$ dispossl costs provide a signisticant incemive for NRC lisenstes to effectively manage LLW generation, treatrem, and disposal from decomrsissioning activities; and (3) decommissioning costs have increased on the order of 34\% to $66 \%$ since the Final Decommissioning Rule was issued in 1988, due in targe part to the 3.5-fold increase in burial costs. 


\section{Contents}

Abstract $\ldots \ldots \ldots \ldots \ldots \ldots \ldots \ldots \ldots \ldots+\ldots+\ldots \ldots \ldots \ldots+\ldots+\ldots \ldots+\ldots \ldots \ldots \ldots \ldots \ldots \ldots \ldots+\ldots \ldots+\ldots \ldots$ iji

Ackrowledgments $\ldots \ldots \ldots \ldots+\ldots+\ldots+\ldots+\ldots+\ldots+\ldots \ldots \ldots+\ldots \ldots \ldots \ldots \ldots+\ldots \ldots \ldots \ldots+\ldots \ldots \quad x i$

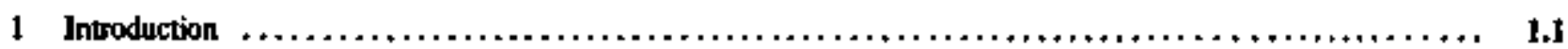

$\$ .1$ References $\ldots \ldots \ldots \ldots \ldots \ldots \ldots \ldots \ldots \ldots \ldots \ldots \ldots \ldots \ldots \ldots \ldots \ldots \ldots \ldots \ldots \ldots \ldots \ldots \ldots \ldots \ldots \ldots \ldots, 1.2$

2 Stumary $\ldots \ldots \ldots \ldots, \ldots \ldots \ldots \ldots \ldots, \ldots \ldots \ldots \ldots \ldots \ldots \ldots, \ldots \ldots \ldots \ldots \ldots \ldots \ldots \ldots, 2.1$

2.1 Decommissioning Allemstives $\ldots, \ldots, \ldots \ldots \ldots, \ldots, \ldots \ldots \ldots+\ldots, \ldots, \ldots \ldots \ldots+\ldots, \ldots, \quad 2.1$

2.2 Review of Decommissioning Experience $\ldots \ldots+\ldots \ldots \ldots \ldots \ldots \ldots \ldots+\ldots \ldots \ldots \ldots \ldots+\ldots+\ldots+\ldots \ldots+2,1$

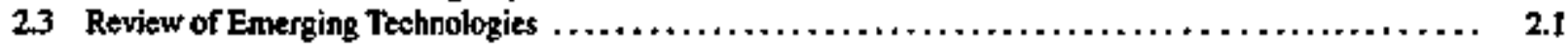

2.4 Characterization of Reference Factlitits and Sites $\ldots \ldots, \ldots, \ldots, \ldots, \ldots, \ldots, \ldots, \ldots, \ldots, \ldots, \ldots, 2.2$

2.5 Decommissioning of Facility Components $\ldots \ldots \ldots+\ldots+\ldots \ldots \ldots+\ldots+\ldots \ldots \ldots \ldots \ldots \ldots+\ldots \ldots+\cdots, 2.2$

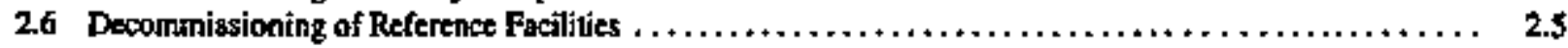

2.7 Decommissioning of Reftertnce Siles $\ldots \ldots \ldots \ldots \ldots \ldots \ldots \ldots \ldots \ldots \ldots \ldots \ldots \ldots \ldots \ldots \ldots, \quad \mathbf{2 . 7}$

2.8 Stody Conclusions $, \ldots, \ldots, \ldots, \ldots \ldots \ldots \ldots \ldots \ldots, \ldots \ldots, \ldots, \ldots \ldots \ldots, \ldots, \ldots, \ldots, 2.8$

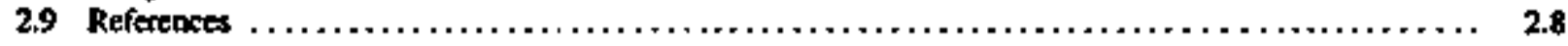

3 Review of Decommissioning Experience $\ldots \ldots \ldots \ldots \ldots \ldots \ldots \ldots \ldots, \ldots, \ldots \ldots \ldots \ldots \ldots \ldots, \quad 3.1$

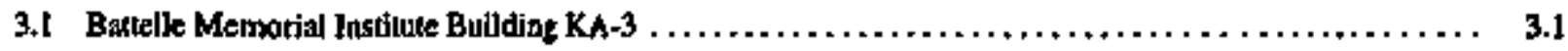

3.1.1 Description of Building KA+3 $\ldots \ldots \ldots \ldots \ldots \ldots \ldots \ldots+\ldots \ldots \ldots \ldots \ldots \ldots \ldots \ldots \ldots, 3.1$

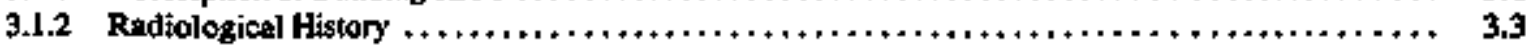

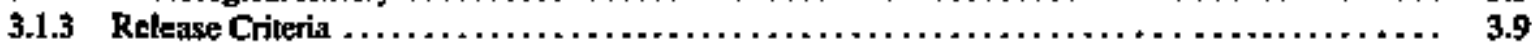

3.1.4 Surmmary of Bvilding KA-3 Decontamination Activities $\ldots \ldots, \ldots, \ldots \ldots \ldots \ldots \ldots \ldots \ldots, \quad 3.9$

3.2 Haffman-la Robe, Inc. Medi-physics Cyclotron Facility $\ldots \ldots \ldots \ldots \ldots \ldots \ldots \ldots \ldots \ldots \ldots \ldots \ldots \ldots \ldots$

3.2.I Description of the Fxcility $, \ldots \ldots \ldots, \ldots, \ldots, \ldots \ldots \ldots, \ldots, \ldots \ldots \ldots \ldots \ldots \ldots \ldots, \quad 3.13$

3.2.2 Radiological History $, \ldots \ldots+\ldots, \ldots \ldots \ldots, \ldots, \ldots \ldots \ldots, \ldots, \ldots \ldots \ldots \ldots \ldots \ldots \ldots, \quad 3.14$

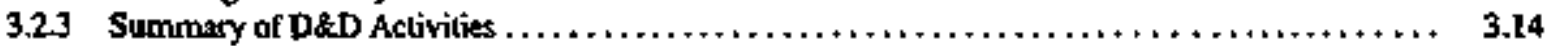

3.2.4 LLW Generation $\ldots \ldots \ldots \ldots \ldots \ldots \ldots \ldots \ldots+\ldots+\ldots+\ldots \ldots \ldots \ldots \ldots \ldots \ldots \ldots \ldots \ldots \ldots \ldots, 3.15$

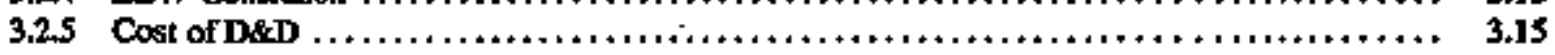

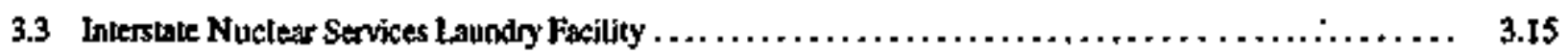

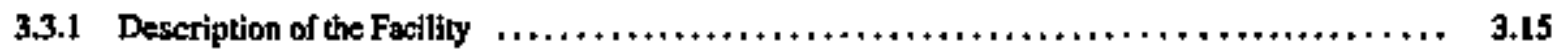




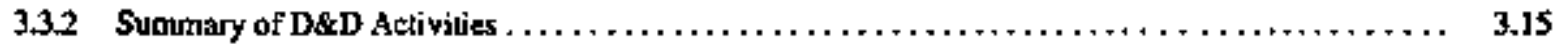

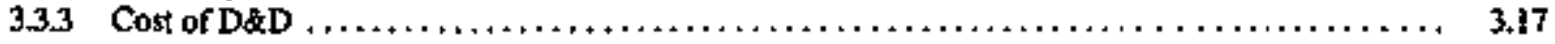

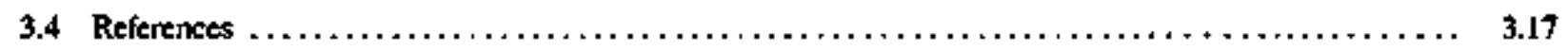

4 Review of Emerging Decontanination Technologies $\ldots \ldots \ldots \ldots \ldots \ldots \ldots \ldots \ldots \ldots \ldots \ldots \ldots \ldots \ldots, 4.1$

$4.1 \mathrm{Ca}_{2}$ Pellet Decontamination Technology $\ldots \ldots \ldots \ldots \ldots \ldots \ldots \ldots+\ldots+\ldots+\ldots+\ldots \ldots \ldots \ldots \ldots \ldots \ldots \ldots+4,1$

4.2 Molten Metal Technology $\ldots \ldots \ldots \ldots \ldots \ldots \ldots+\ldots, \ldots, \ldots, \ldots \ldots \ldots+\ldots \ldots \ldots \ldots \ldots \ldots \ldots, \ldots, \quad 4,2$

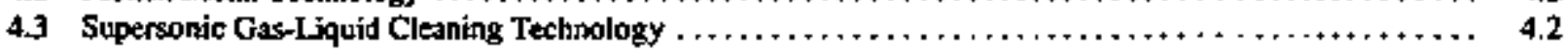

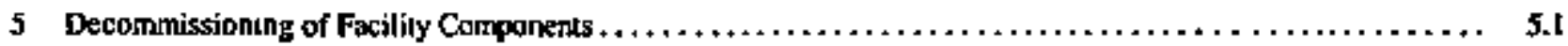

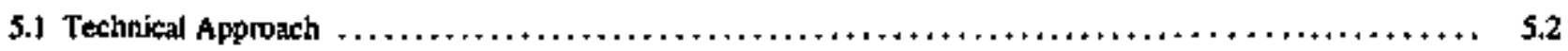

5.1 .1 Cost Estimates $\ldots+\ldots \ldots \ldots \ldots \ldots \ldots+\ldots \ldots \ldots+\ldots+\ldots+\ldots \ldots+\ldots \ldots \ldots \ldots \ldots \ldots+\quad 5.2$

$5.1+2$ Occupational Radiation Dose Eslimates $\ldots \ldots \ldots \ldots \ldots \ldots \ldots \ldots \ldots \ldots \ldots \ldots \ldots \ldots \ldots \ldots, \quad 5.2$

5.2 Decommitssioning Analyses $\ldots \ldots \ldots \ldots \ldots \ldots \ldots \ldots \ldots \ldots \ldots \ldots \ldots \ldots \ldots \ldots \ldots \ldots \ldots \ldots \ldots, \quad 5.2$

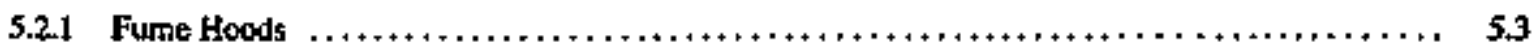

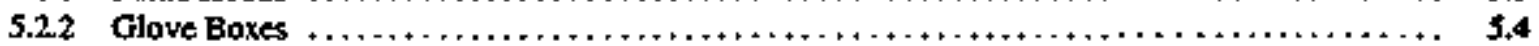

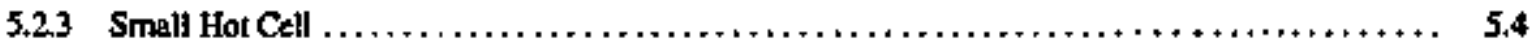

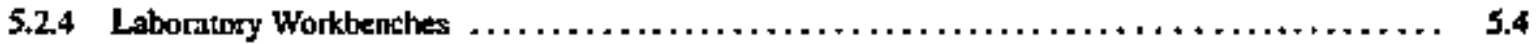

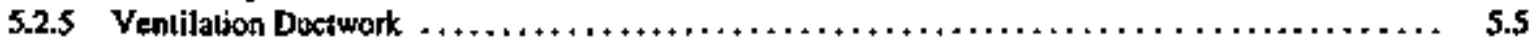

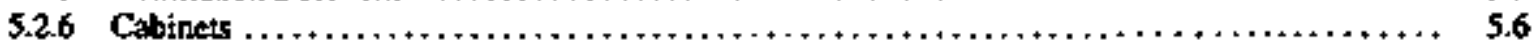

5.2.7 Freezers and Refrigerators $+\ldots \ldots+\ldots \ldots \ldots+\ldots, \ldots \ldots \ldots+\ldots, \ldots \ldots \ldots \ldots \ldots \ldots \ldots \ldots, \quad 5.6$

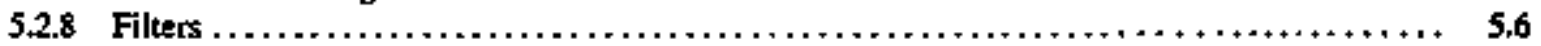

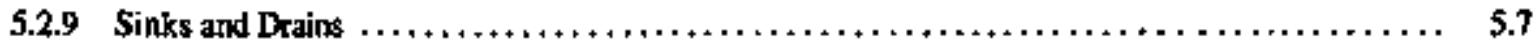

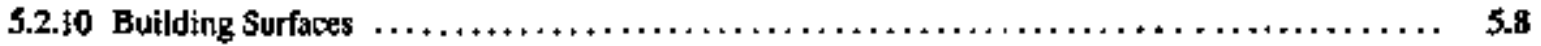

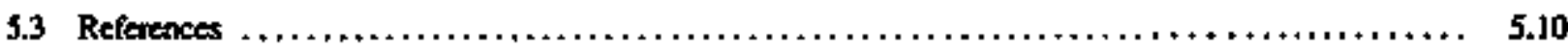

6 Decommissioning of Reference Facilities $\ldots \ldots \ldots \ldots \ldots+\ldots \ldots \ldots+\ldots \ldots \ldots \ldots \ldots \ldots \ldots \ldots \ldots, 6.1$

6.1 Technical Approach $\ldots \ldots \ldots \ldots \ldots \ldots \ldots \ldots \ldots, \ldots \ldots+\ldots \ldots \ldots \ldots+\ldots \ldots \ldots \ldots \ldots \ldots, 6.1$

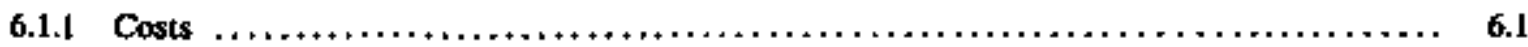

$6.1+2$ Occupational Radiation Dose Estimates $\ldots \ldots \ldots \ldots+\ldots \ldots \ldots \ldots \ldots \ldots \ldots \ldots \ldots \ldots \ldots \ldots \ldots, \quad 6.2$

6.2 Deconumissioning Analyses $\ldots \ldots, \ldots \ldots \ldots \ldots \ldots \ldots \ldots \ldots \ldots \ldots \ldots \ldots \ldots \ldots \ldots \ldots \ldots \ldots \ldots, 6.2$

6.21 Laboratory for the Manufacture of ${ }^{3} \mathrm{H}$-Labeled Compounds $\ldots \ldots \ldots \ldots \ldots \ldots \ldots \ldots \ldots, 6.2$

6.2.2 Laboratery for the Mamufachere of ${ }^{24} \mathrm{C}$-tabeled Compounds $\ldots \ldots++\ldots+\ldots \ldots \ldots \ldots \ldots \ldots, 6.2$

6.2 .3 Laboratory for the Mamufacture of ${ }^{125}$ I-Labeled Compounds $\ldots \ldots \ldots \ldots \ldots \ldots \ldots \ldots \ldots \ldots \ldots, 6.5$

6.2.4 Laboratory for the Mamufacture of ${ }^{1 s} \mathrm{C}_{8}$ Sealed Sourctes $\ldots \ldots \ldots \ldots \ldots \ldots \ldots \ldots \ldots \ldots \ldots \ldots .6 .5$ 
6.2 .5 Loboratory for the Manufacture of ${ }^{2+1}$ Am Sealed Sources $\ldots \ldots \ldots \ldots \ldots+\ldots \ldots \ldots+\ldots \ldots++\quad 6.5$

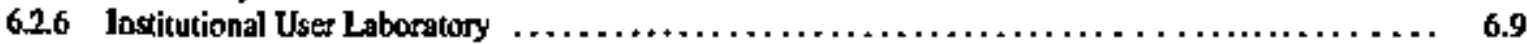

6.3 Analyses and Conclusions $\ldots, \ldots, \ldots, \ldots, \ldots, \ldots, \ldots, \ldots+\ldots, \ldots \ldots+\ldots, \ldots+\ldots, \ldots \ldots, \ldots, \quad 6.9$

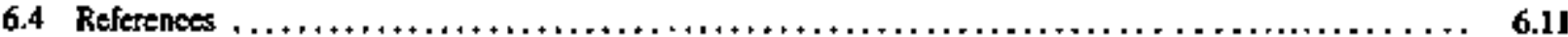

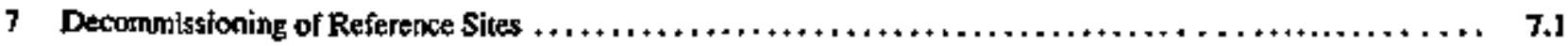

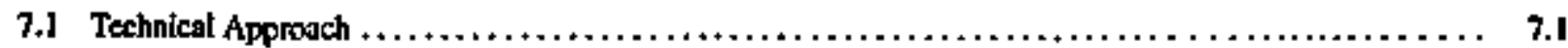

$7,1.1$ Cost Estimates $\ldots \ldots, \ldots, \ldots, \ldots, \ldots, \ldots, \ldots, \ldots, \ldots \ldots \ldots, \ldots \ldots \ldots, \ldots \ldots \ldots, \ldots, 7.1$

7.2 Decormmissioning Analysis $\ldots \ldots \ldots \ldots \ldots \ldots \ldots \ldots \ldots \ldots \ldots \ldots \ldots \ldots \ldots \ldots \ldots \ldots \ldots, \quad 7.2$

7.2.] Contaminated Undergound Drain Line $\ldots, \ldots \ldots \ldots \ldots \ldots+\ldots \ldots \ldots \ldots \ldots \ldots \ldots+\ldots \ldots \ldots \ldots, \quad 7,2$

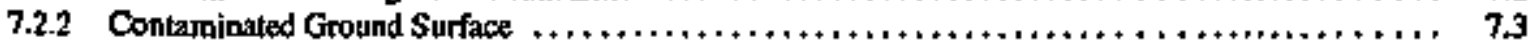

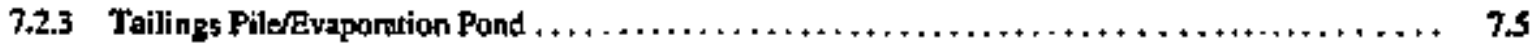

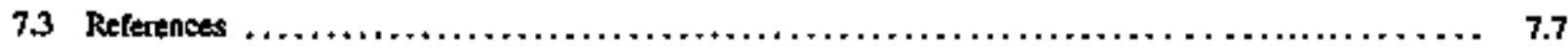

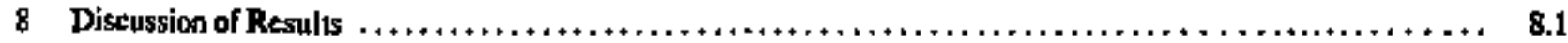

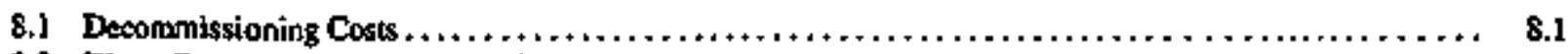

8.2 Waste Generation, Treatment, and Disposal Management $\ldots \ldots \ldots \ldots \ldots \ldots \ldots \ldots \ldots \ldots \ldots \ldots \ldots, \quad 8,1$

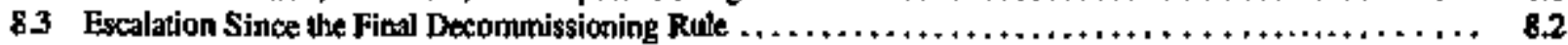

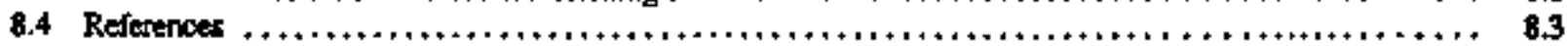

Appendix A - Cost Estimaling Bases $\ldots \ldots \ldots \ldots \ldots \ldots, \ldots \ldots \ldots, \ldots, \ldots, \ldots \ldots \ldots \ldots \ldots, \ldots \ldots, \quad$ A.1

Appendix $\mathbf{B}$ - Process Times Estimating Melhodology $\ldots \ldots \ldots \ldots \ldots \ldots \ldots \ldots \ldots \ldots \ldots \ldots \ldots \ldots \ldots \ldots \ldots \ldots, \quad$ B.1

Appendix C - Detsils of Decommlssioning Facilhy Components $\ldots \ldots \ldots \ldots \ldots \ldots \ldots \ldots \ldots \ldots \ldots \ldots \ldots \ldots, c, 1$

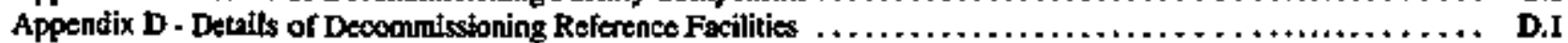

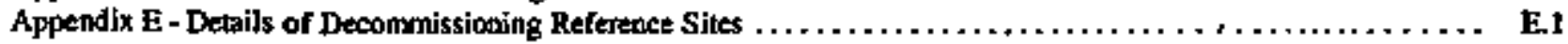


Contents

\section{Figures}

3.1 Floor plan of the second floor of Building KA-3 $\ldots \ldots \ldots \ldots \ldots \ldots \ldots \ldots \ldots \ldots \ldots \ldots \ldots \ldots, \quad 3.2$

3.2 Floor plan of the first floar of Building KA-3 $\ldots \ldots \ldots \ldots \ldots \ldots \ldots, \ldots \ldots \ldots \ldots \ldots \ldots \ldots \ldots, \quad 3.4$

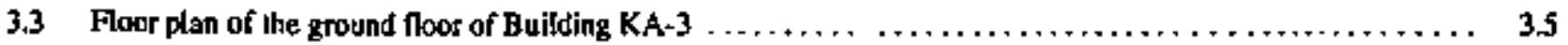

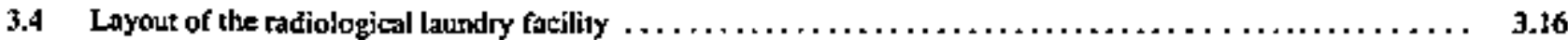




\section{Tables}

2.t Summary of estimated costs for decomunissioning facilny componenls $\ldots \ldots \ldots \ldots \ldots \ldots \ldots \ldots \ldots \ldots \ldots, 2.3$

2.2 Summiry of eslimsled occupational radialion doses for decommissioning facility components $\ldots \ldots \ldots \ldots \ldots \quad 2.4$

2.3 Summary of estimated requitements and costs for DECON of six reference laboratories that process

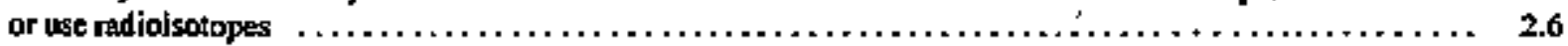

24 Summary of estimated labor requirements, costs, and radiation doses for decommissioning three

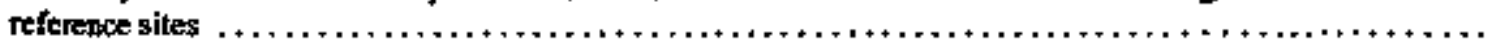

5.1 Contaminated facility components common to the referexce processing and use laboratories

5.2 Summary of estimated marpower requirements, occupational radiation dose, and total costs for DECON of a fume hood

5.3 Sunnary of estimated manpower requirernents, octopational radiation dose, and total costs for DECON of a glove box $, \ldots \ldots \ldots, \ldots \ldots+\ldots, \ldots, \ldots, \ldots, \ldots, \ldots, \ldots+\ldots \ldots \ldots+\ldots \ldots \ldots++,+$

5.4 Summary of estimated manpower requitements, occupational radiation dose, and total costs for DECON of a workbench

5.5 Summary of estimaled manpower requirements, occupational radiation dose, and total costs for DECON of vextilation ducts

5.6 Summary of estimated manpower requirements, occupastional radiation dose, and total costs

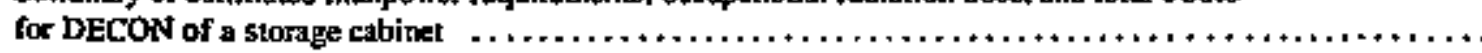

5.7 Summary of estimated manpower requirements, actupational radiation dose, md lotal costs for DECON of a freezer or refrigerator

5.8 Summary of estimated manposier requitements, occupational radiation dose, and total costs far DECON of a HEPA or toughing filter

5.9 Summary of estimated manpower requirements, dxxupational radiation dose, and tolar costs for DECON of a sink and drain

5.10 Summary of estimated manpower requirements, occupational radiation dose, and total costs for DECON of one square meter of ceiling area

S.11 Summary of estimated manpower requirements, occupstionsl radiation dost, and total costs for DECON of one square meter of wall area 
5.12 Summary of esumated manpower requirements, cocupational radiation dse, and total costs for DECON of one square meter of fkor area $\ldots \ldots \ldots \ldots \ldots \ldots \ldots \ldots \ldots \ldots \ldots \ldots \ldots \ldots \ldots \ldots \ldots$

6.I Summary of estımated values of manpower requizements, occupational radiation doses, and costs for decommissioning the reference Iaboratory for the manufaclure of 'H-labeled cornpounts

6.2 Summary of estimated values of manpowet requirtments, oceupational radiation doses, and costs for decommissioning the reference laboratory for the manufacture of ${ }^{14} \mathrm{C}$-labeled compounds $\ldots \ldots \ldots \ldots \ldots$

6.3 Sunmary of estimated values of manpower requirements, ocepational cadiation dosts, and costs

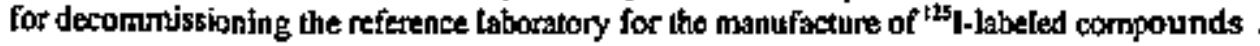

6.4 Summary of estimaled values of manpower requirements, occupational radiztion doses, and costs for decommissioning the reference laboratory for the manufacture of ${ }^{\text {th }}$ Cs sealed sources $\ldots \ldots \ldots \ldots \ldots$

6.5 Summary of eslimated values of manpower requirements, occupational radialion doscs, and costs for decommissioning the reference laboratory for the manufacture of ${ }^{241}$ Am sealed sources $\ldots \ldots \ldots+\ldots \ldots \ldots$

6.6 Sumusary of estimalod values of mampower requirements, oceupstional rediation doses. and costs for decomuissioning the reference institulional user laboratory $\ldots \ldots \ldots \ldots \ldots \ldots \ldots \ldots \ldots$

6.7 Couparison of decommissioning cosıs for Battetle and INS tacilities $\ldots \ldots \ldots \ldots \ldots \ldots \ldots \ldots \ldots \ldots \ldots \ldots$

7.1 Decommissioning options for reference sites $\ldots \ldots \ldots \ldots+\ldots+\ldots \ldots \ldots+\ldots \ldots \ldots \ldots+\ldots \ldots+\ldots+\ldots+\ldots \ldots$

7.2 Summary of estimated labor requirements, costs, and occupational radiation doses for the removal of a contaminated drain line and hold-up tank $\ldots \ldots \ldots, \ldots \ldots+\ldots \ldots+\ldots \ldots+\ldots \ldots \ldots \ldots \ldots \ldots \ldots \ldots+\ldots \ldots \ldots$

7.3 Summary of estimated labor requirements, costs, and oecupational tadiation doses for the removal of contamtnated soil fiom a refertence site.

7.4 Some characteristics of the reference tuilings pile/evaporation pond

7.5 Summary of estimated Jabor requirements, costs, and occupaliongt radiation doses for the stabifization of a reference tatilings pilefevaporation pond

7.6 Summary of estimated labor requiremens, costs, and occupational radiation doses for removal of a reference tailings pile/evaporation pond

8.1 Comparison of decommissionng costs 


\section{Acknowledgments}

The authors gratefully acknowledge the assistance provided by individuals at the Pacjicic North west National Laboratory during the course of this study and preparation of the report. Administraltive atssistante was provided by $H$. A. Nelson.

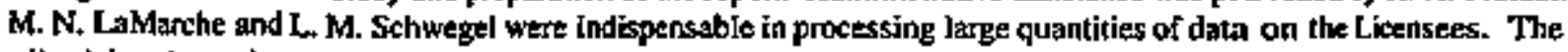
edilorial review prior 10 pulilication was contributed by D. R. Payson.

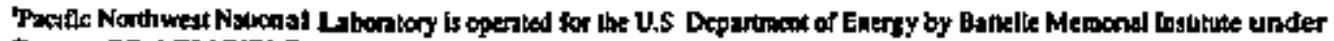
Contrad DE-ACO6-76RLO 1830. 


\section{Intraduction}

This repon cantains the resuls of a study sponsored by the Nuclear Regulatory Commission (NRC) to concepItally decornmission non-fucl-cycle nuelear fucilities. The information provided in this report is a re-analysis of the decommissioning of the facilities and sites considered in NUREOKCR-1754 and its Addendum. (12) This inforanation will be used by the NRC to develop financial assurance sulemakings for by-product, source, and special nuclear materials licensees. The mottrial in this report may also be useftsl to the ficensees in planning for the decommissianing of their facitities. This report covers two broad cakgories: facilitites and sites. As used bercin, a facility is a building whose internal contents (wasks, floors, ceilings, and equipment) are to be decomnissioned. Sik, as defined in this report, is an external area or volume (nol a building) whith contains elements that require decommissioning, such as a hold-up tank, a contarninated ground furface, ox a tailings pile/evaporation pond. Decommissioning a site means deconumissioning one $\alpha$ more of these site elements.

The example facilitles decommissioned in this study are the same as those used in Reference I and ace considered representative of actual facilities. The reference laboratory facilities include Individual laboratories for (1) the manufacture of radiochemicals and sealed sources and (2) institutional leboratories where radioisctopes are used. The study approach used for these facilities is to describe the decomnissioning of components, such as fume hoods, glove boxes, building surfaces, and exhaust system ductwork, that are cornmon to many facilities. Exurniple laboratories are then analyzed using data for indtvidual components (the unit-component approach) to provide representative information about the costs of decombmissinning entire facilities. This sludy analyzes the decommisstoning of example taboratories to unrestricted release levels by the immediate semoval of contaninated components and material and disposal of waste at authorized steres. Facilities may also be decomitaninated to restricted retease levels; however, the new radiological criteria permitying this ${ }^{\text {to }}$ are so recent that it was nol passible to incorporate cost estimate for the restricted velease tose into this study.
The refertente sites are actually site elements for which some effort would be required to remove the radionctive contarnination. The site elements analyzed include a contaminated underground drain line and hold-up tank, a contaminated ground surface, and a tallings pilef evaporation pond containing the radioactive residue from ore processing optrations in which rare metals are recovered from ores comaining licensable quantities of thorium and uranium. Anslysis of the decomnissioning require. ments for these sife elerrents is intended to provide examples to assist in estimating the requirtements and corts of decommissioning siles with similar radioactive contamination. The decommissioniog alternatives analyzed for these sites are (1) site stabilization followed by long-term care and (2) removal of the waste or contaminated soit to an authorized disposal site.

Estirutes are made of manpower requiremnents, work schuduks, materia and equipment ateds, waste maragerrent requirements, and occupational radiation doses for decommissioning facility components, exarngle laboratory facibities, and site elemests by the decommissioning alternative described previously. Decommissioning techniques are chosen that represent current, weilestablished teckrology and that conform to the principle of keeping public and occupational radation doses as low as reasonably achievable (ALARA). Since the publicalion of the base suxdy. (I:3) promisiog new technologites are beginning to be applied (Chapter 4) to the decommissioning of nuclesar facilities. However, because these technokgies we nol yet widely availatle, and because data concerming thetr cost and effectiveness are sparse. none of these new technologies is used in decomrnissioning facilities in this stady.

Foltowing this introductory chapter, a summary of the importan information and results of this study are presented in Chapter 2. Chapter 3 continits a review of deconumissioning experience at three non-fuel-cycle nuckear facilities. Advanced techoologies are covered in Chapter 4. Chapiess 5, 6, and 7 prestent the results of the antalyses for decormunissioning factlity components, reference faoilities, and reference sites, respectively. The 
Introduction

study tesults are discussed in Chapter 8. Cost estumating bases and algorithms are presented in Apperdices $A$ and B. Appendices $C$ through $E$ provide the delanls of the decommussioning analyses sel forth in the main report.

\subsection{References}

1. E. S. Murphy. 198]. Technology, Safeny and Costs of Decommissioning Reference Non-Fuel-Cycle Nuctear Facilities. NUREGCR 1754. U.S. Nuclear Regulatory Commission Report by Pacific Nonthwes1 Laboratory, Richland, Washington.
2. S. M. Short. 1989. Technology, Safery and Costs of Decommissioning Reference Non-Suel-Cycle Nuclear Facilities. NUREG/CR-1754, Addendum ]. U.S. Nuclear Regulatory Comraission Report by Pacific Northwest Laboratory, Rkchland, Washington.

3. U.S. Nuclear Regulatory Commussion. Radiological Criteria for Lcense Terminatuas: Final Ruit.

Federal Regisler, Vol. 2, No. 139, pp. 39057-39092, July 21, 1997. 


\section{Summary}

The objective of this study is to provide relevant information on the tectnology and costs for decommissioning non-fuel-cycle nuclear facilicies. The information in this report updates the information abready provided in the otiginal document and tis addendum on the same subject. (12] This study provides infinmetion far use by NRC slaff in the development of financial assurance nutemakings for by-product mraterials, source materiats, and special nuclear materials licensees. This chaplet provides a brief discussion of the results of the study. A more detailed presertation of results follows in later chapters.

\subsection{Decommissioning Alternatives}

DECON is the decomrissioning altermative analyzed in this study. DECON requires that, shortly afier a facility ceases operalton, alt of its conianinated components eithe- be (1) deconkaminated to restricted or unrestricted release levels or (2) packaged and shipped bo an enthoxtzed disposal site. Although facilities may be decentaminated to restricted release levels, the new radiological critteria permitting this" (3) were promulgated so recently it was not possible to incorporate cost estimates for restricted release into this study. The approsech used to analyze taborattuy decommissioning is to first describe the decommissioning of representalive componterts $(\mathrm{eg}$. fume hoods, glove boxes, building surfaces, exhanst system ductwork) that are common to many laboratories. Example laboratories are then analyzed using data for individual components (the unit-component approach) to provide information aboul the costs of deconturissioning entire facilities.

For the neference sites of this study, the basic decondunissioning alcernatives are (J) site stabilization followed by long term care and (2) removal of the waste or comtaminated soil to sn authorized disposal sile (DECON), For a site that conteins a tailings pile/evaporntion pond, a combination of these altertatives is also possible in which the tailings piletevaporation pond is stabilized and used as a temporary waste storage site.

\subsection{Review of Decommissioning Experience}

A number of non-fuel-cycle facilities have been decommissioned over the last several yetrs. Three of these facilities of particular relevance to this study are discassed in Chapter 3: a facility for conducting US. Government noclear materials research, a faciliay for the manufacture of radiopharmaceuticats, and a radiologicat laundry facility used to decontaminate ctothing and other articles that have been radiologically contarminated at nuclear facilities. These facilities wert selectod for inclusion in this study because they represent the broad range of types of facilities classified as non-fuel-cycle facilities and she resulping broad range in decommissioning requirements.

The intent of Chapter 3 is to provide information on the types of non-fuef-cycle facilttites thal have been decommissioned over the last several years and to provide some perspective of the complexity and level-of-effort required to decomurnission different types of tacilitites.

\subsection{Review of Emerging Technologies}

The rapidly escalatiog cost for disposing of radicactive waste at the avajlable shallow-land disposal sites has provided the impetus to develop technologies that reduce the volume of waste that must be shipped for disposal. Thre such technokgies, including 1 wo surfaco decontamination methods and a molten malal process, are discussed in Chapter 4. Although they are not used ta the development of the cost methodology discussed in this study, these tectinologies are evaluated al some knglh because of the potential impact they may have on the overal] cost of decomatissioning in the foture. 


\subsection{Characterization of Reference Facilities and Sites}

The reference facilities and sites analyzed in ihis study are the stame as those in NUREG/CR-1754." The reference laboratories include;

- a laboratory for the manufacture of ${ }^{3} \mathbf{H}$-labeled compounds

- a laboratory for the manufacture of 'A-Jabeled compounds

- a laboratory for the manufacture of tat Isbeled cotmpounds

- a laboratory for the manufacture of ${ }^{1} \mathrm{C}$ s sealed sources

- a laboralory for the manufaclure of ${ }^{211}$ Am sealed sources

- a reference institutional user laboratory.

These facilities ae described in detail in Section 7 of NURECKCR-1754.(1) Several facility coutuonents are common to the reference Jaboratones. These conmponents include fume hoods, glove boxes, hot cells, laboratory workbenches, stocage cabinets, fitters, smill appliances, sinks, draios, ventilation ductwork, fitters, and building surfaces (floors, walls, and ceilings). Some of these components become signifocanty contarinated during the operational phase of the laboratory, Release of a laboratory for unrestricted use and termination of the radiosctive maleritl license require that $\{1\}$ a contantarted component be decontaminnied to unestricted rilease levels, with wastes packaged and shipped to a waste disposal site or (2) the entire component be packaged and shipped to an authorized dusposal site.

The seference siles include:

- a site with a cocttaminated drain line and hold-up tank

- a site with a contaniziated gound suf face

- a tailings pile containing uranium and thocium residues.
As with reference facilities, unrestricted release of Jeference sties would require that the contamination be renksved and disposed of at an authenzed dispostal facility before the license could be terminald. Some situations Tway exist, such as at the site of a tallings pile, where the cost of remadiation necessary to redice contamination levels to allow turestricted release may be prohibitively expersive. Decommissioning of such sites could be completed with restricled relense of the sile, provided arrangemenis were established to assure that further use of the site would be limited to certan activities. Surveillance of the remaining contamnation may be required of the original licensee or another qualified alternate until residual radioacti vity decays to levels allowing unrestricted relepase.

Two decommissioning oplions for the sile with a contaminated toilings pile ve analyzet in this study: (1) remaral of all contarrinated thisenal to atlow unrestricted release, and (z) site stabilization followed by periotic surveillance to alfow restrated release.

\subsection{Decommissioning of Facility Components}

Facility components may be decomatssioned by deconcamintión to restricted release levels, unfestricted release levels, or by shipanent to a low-level wasle (LLW) facility. Previous studies ${ }^{(1, t)}$ analyzed several options for remowable components: (l) decontanimation to unrestrícted release levels, (2) packaging and disposal withour volume reduction, (3) packaging and disposal with super. compaction, and (4) packaging and disposal with incineration. The labou cost of decontaninating componems to unrestricted levels is porentially wery high, usually higher than the salvage value of the decontamannaled component. Such intensive decontamunation effonts also generate significant amounts of secondary waste that must be disposed of. For these reasons, option 1 was not corsideres in this study. Sirre disposal charges $\left(\$ / \mathbf{m}^{3}\right)$ at the LLW disposal sties have increased dramatically since the original study, option 2 is mo longer considered wable. Based on these considerations, only options 3 and 4 are andyzed for the removalale companens in this scody: building surfaces are decontaminaled to unrestricted release levels. A summtary of estfristed costs for decommissioning tacility components is gives in Table 2.t. A 
Table 2.1 Summary of estimated costs (\$ thousands) for decommlssioning facllity compoents

\begin{tabular}{|c|c|c|c|c|c|c|}
\hline $\begin{array}{l}\text { Component } \\
\text { \& option }\end{array}$ & $\begin{array}{c}\text { 'H } \\
\text { lahoratory }\end{array}$ & $\begin{array}{c}\text { 14C } \\
\text { Ehoratory }\end{array}$ & $\begin{array}{c}1231 \\
\text { lahoralory }\end{array}$ & $\begin{array}{c}{ }^{197} \mathrm{Cs} \\
\text { bhorgtory }\end{array}$ & $\begin{array}{c}21 \mathrm{Am} \\
\text { Laboralory }\end{array}$ & $\begin{array}{c}\text { User } \\
\text { laborzicy }\end{array}$ \\
\hline $\begin{array}{l}\text { Fune hood } \\
\text { Option I } \\
\text { Option } 2\end{array}$ & $\begin{array}{l}7.5 \\
7.9\end{array}$ & $\begin{array}{l}8.0 \\
8.3\end{array}$ & $\begin{array}{l}7.5 \\
7.7\end{array}$ & $\begin{array}{l}9.1 \\
9.4\end{array}$ & $\begin{array}{l}8.0 \\
8.4\end{array}$ & $\begin{array}{l}7.6 \\
7.5\end{array}$ \\
\hline $\begin{array}{l}\text { Glove box } \\
\text { Option } 1 \\
\text { Option } 2\end{array}$ & $\begin{array}{l}3.3 \\
3.5\end{array}$ & $\begin{array}{l}3.5 \\
3.6\end{array}$ & $\begin{array}{l}4.0 \\
4.0\end{array}$ & $\ddot{-}$ & $\begin{array}{l}6.7 \\
7.0\end{array}$ & $\begin{array}{l}3.5 \\
3.7\end{array}$ \\
\hline $\begin{array}{l}\text { Hol cell } \\
\text { Option ] } \\
\text { Option } 2\end{array}$ & + & $\overline{-}$ & $=$ & $\begin{array}{l}265 \\
26.8\end{array}$ & $\ddot{-}$ & \pm \\
\hline $\begin{array}{l}\text { Wotkbench }{ }^{\text {or }} \\
\text { Optiont 1 } \\
\text { Option } 2\end{array}$ & $\begin{array}{l}2.6 \\
2.7\end{array}$ & $\begin{array}{r}9.9 \\
12.4\end{array}$ & $\begin{array}{l}8.7 \\
9.0\end{array}$ & $\begin{array}{l}11.8 \\
14.4\end{array}$ & $\begin{array}{l}10.6 \\
10.8\end{array}$ & $\begin{array}{r}9.3 \\
11.9\end{array}$ \\
\hline $\begin{array}{l}\text { Dutetwork" } \\
\text { Optien } 1 \\
\text { Option } 2\end{array}$ & $\begin{array}{l}13.1 \\
13.5\end{array}$ & $\begin{array}{l}13.6 \\
14.0\end{array}$ & $\begin{array}{l}15.9 \\
16.3\end{array}$ & $\begin{array}{l}17.2 \\
17.6\end{array}$ & $\begin{array}{l}15.1 \\
15.5\end{array}$ & $\begin{array}{l}14.2 \\
14.6\end{array}$ \\
\hline $\begin{array}{l}\text { Cotbinet } \\
\text { Option ] } \\
\text { Option } 2\end{array}$ & $\begin{array}{l}2.4 \\
3.0\end{array}$ & $\begin{array}{l}2.4 \\
3.0\end{array}$ & $\begin{array}{l}23 \\
23\end{array}$ & $\overline{-}$ & $\begin{array}{l}2.4 \\
2.9\end{array}$ & $\bar{z}$ \\
\hline 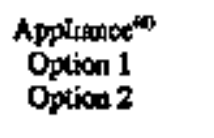 & $\begin{array}{l}5.9 \\
6.2\end{array}$ & $\begin{array}{l}60 \\
6.3\end{array}$ & $\begin{array}{l}6.3 \\
6.7\end{array}$ & 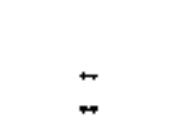 & $\ddot{-}$ & $\begin{array}{l}5.9 \\
6.2\end{array}$ \\
\hline $\begin{array}{l}\text { Filut } \\
\text { Option 1 } \\
\text { Oplion } 2\end{array}$ & $\begin{array}{l}0.2 \\
0.2\end{array}$ & $\begin{array}{l}0.2 \\
0.2\end{array}$ & $\begin{array}{l}0.2 \\
0.3\end{array}$ & $\begin{array}{l}0.2 \\
0.3\end{array}$ & $\begin{array}{l}0.2 \\
0.2\end{array}$ & $\begin{array}{l}0.2 \\
0.2\end{array}$ \\
\hline $\begin{array}{l}\text { Sink \& drin } \\
\text { Option I } \\
\text { Option } 2\end{array}$ & - & $\begin{array}{l}23 \\
23\end{array}$ & $\begin{array}{l}2.4 \\
2.4\end{array}$ & $\begin{array}{l}2.5 \\
2.5\end{array}$ & $\overline{-}$ & $\begin{array}{l}2.2 \\
2.2\end{array}$ \\
\hline $\begin{array}{l}\text { Ceiling't } \\
\text { Optivm I } \\
\text { Option } 2\end{array}$ & $\begin{array}{l}11.8 \\
15.6\end{array}$ & $\begin{array}{l}\mathbf{1 2 . 0} \\
\mathbf{1 5 . 8}\end{array}$ & $\begin{array}{l}\mathbf{1 5 . 1} \\
\mathbf{1 7 . 6}\end{array}$ & $\begin{array}{l}24.0 \\
32.1\end{array}$ & $\begin{array}{l}12.8 \\
14.9\end{array}$ & $\begin{array}{l}17.6 \\
25.1\end{array}$ \\
\hline $\begin{array}{l}\text { Waltion } \\
\text { Option } 1 \\
\text { Option } 2\end{array}$ & $\begin{array}{l}\mathbf{1 0 . 0} \\
11.9\end{array}$ & $\begin{array}{l}10.6 \\
12.5\end{array}$ & $\begin{array}{l}14.8 \\
16.6\end{array}$ & $\begin{array}{l}15,3 \\
17,1\end{array}$ & $\begin{array}{l}11.5 \\
13.0\end{array}$ & $\begin{array}{l}15.6 \\
17.9\end{array}$ \\
\hline $\begin{array}{l}\text { Flook } \\
\text { Option } 1 \\
\text { Option } 2\end{array}$ & $\begin{array}{l}10.1 \\
10.1\end{array}$ & $\begin{array}{l}\mathrm{dt} .1 \\
\mathrm{~d} .4\end{array}$ & $\begin{array}{l}12.5 \\
{[2.8}\end{array}$ & $\begin{array}{l}13.6 \\
14.0\end{array}$ & $\begin{array}{l}13.4 \\
15.4\end{array}$ & 11.5 \\
\hline
\end{tabular}

(a) Option 1 is supercompaction. Option 2 is supercompaction with incinaration.

(b) Cost for a "typical" wark bench. 4,6 m long.

(c) Cost for $40 \mathrm{~m}$ of yentilsijur dectwork.

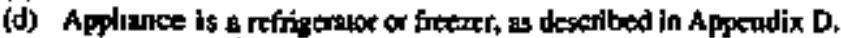

(e) Cost for $60 \mathrm{~m}^{2}$ of suriact ares 
summary of estimated occupational radiation doses for decommissioning facittly components is given in Table 2.2

Contamination levels on facility components before decontamination are grvet in NUREGKCR-1754. ${ }^{\text {(1) }}$ Decontarmuation procedures ase descnbed in Appencix B of that document. Decontarination is assumed to reduce removable surface decontamination to the unrestricted release levels specified in the NRC guidelites of Reference 1.

Disposal Is possulated to be by shallow-land dísposal at a tite localed $800 \mathrm{~km}$ from boh the laboratory being decommissioned and from the centrally located supercompaction faclity. The supercompaclion and incineration facility is postulaled to be locned $350 \mathrm{~km}$ from the laboratory. Wastes are packaged in 20B-liter steel drums and are shipped by truck either to the disposat sile or to the supercompaction and incineration facifily. Both the contaminated components and the decomunissioning wasles, with the exception of contaninaled [iquids, are disposed of in this manner. Conksmmated liquids are solidified on-site and always shipped dyectiy to the disposal síle.

Decommissioning costs include the costs of staff labor, equipment and supplies, and wasle management (the packstsing, volume reduction, transportation, and disposal of wasles). All costs are expressed in January 1998 dollars. Total costs include a $25 \%$ contingency.

Decommissioning of facility components is assumed to be performed by employes of the ownerfoperalor of the facility. Staff jabor costs are determaned by multiplying the crew-hours required lo decomarsston a component by athe costs per crew-hour. To determune the total time Jequred to decommission a component, an estimate is made of the time required for efficient perforrsnnce of the work by a postulated work crew. This time estimate is then increased by $50 \%$ to allow for preparalion and set-up time and rest periods.

Table 2.2 Summary of estinasted ocupaltional radiation doses (person-rem) tor decommissioniag Tactlity components

\begin{tabular}{|c|c|c|c|c|c|c|}
\hline $\begin{array}{l}\text { Component } \\
\text { \& eption (t) }\end{array}$ & $\begin{array}{c}\text { JH } \\
\text { laborratory }\end{array}$ & ${ }^{17} \mathrm{C}$ & $\begin{array}{c}\text { म'I } \\
\text { Gahoratory }\end{array}$ & $\begin{array}{c}\text { W/Cs } \\
\text { laboralory }\end{array}$ & $\begin{array}{c}{ }^{11} \mathrm{Am} \\
\text { laboratory }\end{array}$ & $\begin{array}{c}\text { User } \\
\text { laborator }\end{array}$ \\
\hline Fume hood & $8 \times 10^{3}$ & $8 \times 10^{6}$ & $3 \times 10^{5}$ & $I \times 10^{1}$ & $5 \times 10^{-2}$ & $8 \times 10^{-3}$ \\
\hline Glove box & $7 \times 10^{4}$ & $2 \times 10^{2}$ & $4 \times 10^{3}$ & - & $2 \times 10^{\circ}$ & $7 \times 10^{4}$ \\
\hline Hot cetl & - & - & - & $2 \times 10^{9}$ & -- & - \\
\hline Workbeach'os & $2 \times 10^{7}$ & $6 \times 10^{2}$ & $1 \times 10^{3}$ & $3 \times 10^{3}$ & $4 \times 10^{3}$ & $6 \times 10^{\circ}$ \\
\hline Ductwork ${ }^{(0)}$ & $2 \times 10^{4}$ & $2 \times 10^{3}$ & $6 \times 50^{5}$ & $3 \times 10^{3}$ & $1 \times 10^{2}$ & $2 \times 10^{-6}$ \\
\hline Cabinex & $2 \times 10^{4}$ & $7 \times 10^{2}$ & $2 \times 10^{5}$ & - & $3 \times 10^{-3}$ & - \\
\hline Applianceste & $2 \times 10^{4}$ & $1 \times 10^{4}$ & $2 \times 10^{5}$ & - & - & $2 \times 30^{6}$ \\
\hline Filter & $1 \times 10^{2}$ & $5 \times 10^{4}$ & $1 \times 10^{6}$ & $2 \times 10^{6}$ & $2 \times 10^{-1}$ & $1 \times 10^{7}$ \\
\hline Sink \& drain & - & $9 \times 10^{*}$ & $1 \times 10^{-6}$ & $1 \times 10^{5}$ & - & $9 \times 10^{-4}$ \\
\hline Ceilugg(a) & $7 \times 10^{6}$ & $3 \times 10^{4}$ & $9 \times 10^{5}$ & $1 \times 10^{-4}$ & $2 \times 10^{-2}$ & $8 \times 10^{6}$ \\
\hline$W_{a^{\prime}} !^{(\infty)}$ & $6 \times 10^{\circ}$ & $3 \times 10^{4}$ & $9 \times 10^{5}$ & $1 \times 10^{-4}$ & $2 \times 10^{2}$ & $1 \times\left[0^{5}\right.$ \\
\hline Floor & $1 \times 10^{6}$ & $4 \times 10^{4}$ & $5 \times 10^{4}$ & $2 \times 10^{4}$ & $4 \times 10^{-2}$ & $3 \times 10^{-6}$ \\
\hline
\end{tabular}

(a) Dose from a "typical" workbench, $4.6 \mathrm{~m}$ long.

(b) Dose from 40 m of ventilation duct.

(c) Appliance is a refrigeralnt or freener, as described in Appendix D.

(d) Dose from $60 \mathrm{~m}^{2}$ of surface area. 
The base-case scentrio for deterrining the reguirements and costs of disposal of facitity components assumes that current decommissioning practice is followed and that components are cut up into pieces tost will efficienily fill a 208-liter drum. The drums are then compacted on-site and sent to a facility for supercompaction, after which they are sent to a shallow-land disposal site as LLWW. To provide a basis for cost comparisons, an altemative option is andyzed which is identical to the base case except that butrible waste is incinerateo and the remainder is supercompacied. Cosis of these two pptions are summarized in Chapler 5.

An estirnate of occupational dose is made for the decommissioning of each facility component. The occupational dose is evaluated by trulliplying the estimated worker dose rate for a component by the person-hours required to deconarission the component. The estirnated worker dose rates that form the bases of occupational dose calcylation are given in Section 8.1 of NUREGCCR-1754 ${ }^{13}$ and inciude conlributions from bath direct expesure and inhalation. The worker dose rates used in thir stady are in reaconsble agreement with the experience at typical radioactive materials laboratories.

\subsection{Decommissioning of Reference Facilities}

Estimates are made of time and manpower requirements, ocerepational radiation doses, and toutal costs for DECON of the six reference laboratories listed in Section 2.4. The decomrrissioning analyses for these laboratories use cost data for the decommdssioning of facility components summarized in Section 2.5. Costs of planning and preparation and of a final radiation survey of the decomruissioned facility are added to the basic decontamination costs of the individual components.

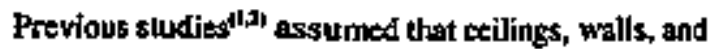
floors of the futilaties were to be decentaminated to unrestrioked release levels and that some of the facility components were to be decontaminated to unsestricted release kevels. while others wero to be sectioned and packaged for disposal. The original study (1) discussed the relative nerits of compacting compotintes befoce disposal. But in the analyses of complete factities. novolume reduction of components was assumed. The follow-on stud $y^{(2)}$ considered options of cernpaction and supercompaction. The present study differs from the previous two studies in that only surfaces (walls, ceilings, floors) are deconlaminated to unresiricted telease levels; no facility componenls art decontaminated. Instead, all components are to be supercompacted or incinerated before they are dispostd of. Decommissioning requirements and cosis for the six reterence laboralories are summarized in Table 2.3.

Deconmissioping is preceded by a period of planning and preparation that includes activities to chsure that decorturissioning is performed in a safe and costeffective manner in accortance with all applicable Federal, State, and local regulations. Planning and preparation activities include the prepartion of documentation for regulatory agencies, an initial rediation survey to determine the radiological condition of the laboratory, and the development of detaited work plans.

DECON aptions postulated for the components of the reference laboratories represent reasonable approaches to the decommissioning of particutar components. Al] components (furne haods, glove boxes, filters, dueting. workbenehes, cabinels, refrigerators, sinks and drains, and ocher similar jtems) are sectioned to the extent possi. ble, compacted, and then packaged for disposal. The only surface dexontarnination performed on these items is the mipispurt amount needed bo prevent the spread of contamimation during the sectioning and packaging operations. Bnilding surfaces are generally tssumed to be decomiaminated to unrestricted use levets.

The decommissioning activities evalmat in this report to nat include consideration of sigsificantly off-notrmal conditions, such as spread of contamioation within the struetural walls or bereath the primary covering of the noors of the facility. Because of the vaigue characteristics of such situations, they cannot be evalusted in the same generic manner as is done for the abmal conditions. If these cypes of conditions exist in a facility, specific analyses by the owner will be necessary to estimate the cosis of these additional cieanup operalions, which would then be added to the estimates developed using the methodalogy and unit coss factors presented in this report. 
Table 2.3 Sumulary of estimated requirements and costs for DECON of six reference baboratories that process er use radloisotopes

\begin{tabular}{|c|c|c|c|c|c|c|}
\hline \multirow[b]{2}{*}{ Parameter } & \multicolumn{6}{|c|}{ Eequirement arcost tor veferemce laboratory } \\
\hline & $\begin{array}{c}\text { 'H } \\
\text { Laboratory }\end{array}$ & $\begin{array}{c}{ }^{14} \mathbf{C} \\
\text { bearstort }\end{array}$ & $\begin{array}{c}{ }^{12} I \\
\text { laboratory }\end{array}$ & $\begin{array}{c}\text { 13y } \mathrm{Cs} \\
\text { laboratory }\end{array}$ & $\begin{array}{c}241 \mathrm{Am} \\
\text { labegrafory }\end{array}$ & $\begin{array}{c}\text { User } \\
\text { Lghoralory }\end{array}$ \\
\hline \multicolumn{7}{|l|}{ Supercompaction option } \\
\hline Time (diys) & 61 & 57 & 50 & 48 & 58 & 68 \\
\hline Marpower (person-days) & 194 & 178 & 149 & 143 & 179 & 220 \\
\hline Dose (persan-rem) & 0.04 & $\$ 001$ & 0.02 & 4 & 13 & 0.04 \\
\hline \multicolumn{7}{|l|}{ Costs (\$ thousands) } \\
\hline Stuff labor & 85.1 & 77.9 & 65.0 & 62.4 & 780 & 96.5 \\
\hline Equipment \& supplies & 30.0 & 29.4 & 28.5 & 28.4 & 29.4 & 30.5 \\
\hline Waste management & 590 & 586 & 35.4 & 648 & 394 & 772 \\
\hline Totals & 174.1 & 165.9 & 128.8 & 155.4 & 1468 & 204.8 \\
\hline \multicolumn{7}{|l|}{$\begin{array}{l}\text { Supercotnpaction with } \\
\text { incineration }\end{array}$} \\
\hline Time (days) & 61 & 57 & 50 & 48 & 58 & 68 \\
\hline Manpower (person-days) & 194 & 178 & 149 & 143 & 179 & 220 \\
\hline Dose (person-rem) & 0.04 & $<0.00]$ & 0.02 & 4 & 13 & 004 \\
\hline \multicolumn{7}{|l|}{ Cosis (\$ thousands) } \\
\hline Staff Labor & 85.1 & 7.9 & 65.0 & 62.4 & 78.0 & 96.5 \\
\hline Equipment \& supplies & 30.0 & 29.4 & 28.5 & 28.4 & 29.4 & 30.5 \\
\hline Waste managerment & 77.3 & 80.9 & 43.3 & 78.8 & 52.3 & $\log 5$ \\
\hline Totals & 192.3 & 188.1 & 136.7 & 169.4 & 159.7 & 236.5 \\
\hline
\end{tabular}

The final decomnissioning activity is a comprehensive radiological survoy to document levels of radiouclivity remainting in the facility after DECON is completed and to certify that these ievels are less than those specified for unrestricted reterase.

Decommissioning is assumed to be pefformed by employees of the owners or operatiors of the laboratories.
The basic decorrunissioning work crew includes a foreman and thee techniciarts, assisted by a bealth physicist. Craftsmen (electricians, pipefitters, etc.) are added to this crew on a part-time basis to perform specific tasks. Staff labor costs are postulated to include the salary of a supervisor on a half-time basis. 
Costs for desortynissioning the reference laberalorites include the cosis of $s$ taff labor, equipment and supplies, and waste managemert. Cosis are estirnated for planming and preparation, for the actuat decommissionting, and for the termination survey. Total costs, listed in Tabte 23. are the sum of all of these costs. All costs are expressed in January 1998 dollers and include a $25 \%$ conlingency.

Estimates of occupational rodistion dase are made by multiplyiog worker dose rales given in Section 8.1 of NUREGKCR-1754 $4^{(1)}$ by the estimaled person-days required to decommission a facility.

A note reganding the ${ }^{21}$ Am laboratory is in order. As discussed in Appendix D, the walls and ceiling in this facility are coperette and sealed with acrylic paint. As a resulh, the poslulzted cleanup of these surfaces invelved only wet-wiping and the application of strippable paint. Thus, decontamination to release levels was easily achieved. However, bad the surfaces not been sealed, the decontamination to release kevels of surfaces impregnated by ${ }^{211}$ Am could have required extensive surface washing and scabbling of concrete to depths of at least $0.6 \mathrm{~cm}$ Assuming, as a worst case, that all $60 \mathrm{~m}^{2}$ of ceiling and foor area and alt $168 \mathrm{~m}^{2}$ of wall artea required washing ind scabbling, using procedures tike those discussed in References 3 and 4 , the cost of decommisstoning this factity would have increased about \$67,000. This amounts to a $46 \%$ increase in decomrtissianing costs for the supercompaction option and a $42 \%$ increase for the superconflaction with incineration optom.

\subsection{Decommissioning of Reference Sites}

Estinates are made of tirpe and manpower requitements, oceupational radiation doses, and lotal costs for decommissioning the three reference sites listed in Section 2,4. For the site with a contaminated ondrgrand drain line and haid-up cank and for the site with a contaminated ground surface. estimotes are made of the requirements and costs for removing the radioactively contaminated material. For the sile with a tailings pile containing utanium and thoxitrm residtes, estimstes are made of requirements and costs for both the sile slabilization and the remoyal options. Decommissioning requirements. occupational doses, and costs for the lluee reference sites are surrantizized in Table 2.4.

Because concentrations of radioactivity are assumed to be low and inhalation of re-suspended particulates is not a serious consideration, removal of the waste and contaminated soil is accomplished with standani earthmoving equipmenl. Rsdioactive material is packaged in 208. liter drums or B-25 metal contaisters far stipment to a shallow-land dispossal site.

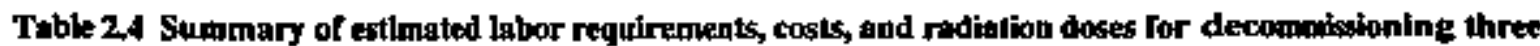
reference altes

\begin{tabular}{|c|c|c|c|c|}
\hline \multirow[b]{2}{*}{ Site } & \multicolumn{4}{|c|}{ Requirement or cost } \\
\hline & $\begin{array}{l}\text { Thone } \\
\text { (days) }\end{array}$ & $\underset{\text { (person-days) }}{\text { Lobor }}$ & $\begin{array}{c}\text { Costs } \\
\text { (s) thoussingds) }\end{array}$ & $\begin{array}{l}\text { Ocupotional } \\
\text { redkation } \\
\text { dose (ntron-rem) }\end{array}$ \\
\hline Underground drain line \& hold-up unt & 17 & 72.5 & 126 & 0.052 \\
\hline Contaminated ground surface & 42 & 209 & 1,396 & 0.149 \\
\hline Tailings prle & & & & \\
\hline Stabilization option & 32 & 174 & 237 & 0.139 \\
\hline Long-terus care & 10 & 27 & 17 & 0.022 \\
\hline Removal option & 139 & 1,657 & 22,790 & 1.311 \\
\hline
\end{tabular}

(a) Cost are in bavery 1998 dollas and include $125 \%$ contiograncy 
Sumnary

For the sile with a contaminated tailings pile, site stabilyzation is assumed to include the following procedures.

The pile is covered with a 50 -mm-thick layer of asphale. This asphalt layer is then covered with 1 m of soll. The soil is mounded slightly at the center of the pile to allow water to dirin from the soil cover and to prevert the accumulation of runoff from ranfall or snow melt. After compaction and contouring of the soil cover, the aren is seeded with grass.

Decomnissioning activities inctude a radiological survey to assess the condition of the sice before site stablization or removal operations begin and restoration of the sito by backfilling and planting vegetaltion atter waste removat is completed. A final radiation strwey to verify that the radioactivity rempining on the sute is less than release limits is performed before releasing the site for unrestricted use. Dexammissioning is assurmed to to performed by a contractor hired by the owner or operator of the site.

Decomonissioning costs include the costs of taff lalkor. equipment, supplies, soil sample antylyses, waste management, and a contractor's fee. Total costs shown in Table 2.4 are the sum of plamning and preparation, actual decomrrissioning, and termination survey costs. At costs are expressed in early 1998 dollars and include a $25 \%$ contingency. Approximately 77\% of the cost of decommissiouing a site with contaminated gound sarface, and approximately 91\% of the cost of the removal option for decmurssioning a tailings pik, is related to waste management (i.e., the packaging. Iransportation, and disposal of soil and waste exhumed for the sic $\varepsilon$.

Cocupational radialion doses are estimated on the basis of an assumed average dose rise of 0.1 inrembr to decors missipning workers. This exposure level was estımated on the basis of experience at teilings sites and L.LW disposal sites and chosen conservatively.

\subsection{Study Conclusions}

The trajor conclusions of this study are:

- Deconmissioning of materiats factities can be accomplished using techniques and equipment that are in common industrial use.
- Decomúissioning costs vary ortr a whde range, from thousands to millions of dollars, depending on the type and size of the facility, the nature and extent of the radioactive contamination, and the operating history of the facility.

- Materials facilities can be decommissioned with a minirmum of radiation exposure ta decommissioning workers and with no significant impact on the safely of the general public.

- Facility design and construction and operating practices car have a sigm ficant effect on the time and cost of decommissioning malerials facilities.

- Whale new, commercially avalable radianctive waste vohume-reduction 1echnology can sienificantly reduce the costs of waste disposal, the repidly escalating dispostrl charges al the LLW sites, coupled with the inevitable fncreases in labor and materials, have resulted in an overall increase tn decormmissioning costs. Thete cost increases are on the order of $34 \%$ to $66^{\%}$, since issuance of the Final Decommissibning Rtule in 1988.

- The decommissioning cost methodology presented in this report is in fairly good agreement with decommissioning cost estimates provided by licenses to the NRC.

\subsection{References}

1. E. S. Murphy. 1981. Technology, Safery and Costs of Decommisstoning Reference Nan-Fuel-Cyeite Naclear Pacilities. NUREG/CR-1754. U.S. Nuclear Regulatory Comrnission Report by Pacific Northwest Laboratory, Richland, Washington.

2. S. M. Short 1989. Technology, Sofety and Casts of Decommissioning Reference Nor-Fuel-Cycle Naclear Faclinies. NUREG/CR-1754, Addendum 1. U.S. Nuclear Regulatory Commussion Report by Pacific Northwest Laboratory, Rúbland. Washington.

3. U.S. Nuclear Regutatory Comnussion Radiological Criteria for License Termination final Rule. Federal Register, Vol. 2, No. [39, pp. 39057-39092, July 21, 1997. 


\section{Review of Decommissioning Experience}

Since publication of the Addendum to NUREG CR-1754, (1) several commercial and Depastrient of Energy (DOE) non+fuel-cycle facilities have been decommissioned. Three of these facilities relevant to this study are discussed in this chapter. These examples were chosen to illustrate the variety of facililies that have been decomrnissioned in the past few years. The nature, size, and complexily of these example facilities vary, bot the same bissic decorrsitssioning methods apply to each of thent. These methods were used in late aralyses of the reference labocatory tacilities and refereuce sikes in Chapters 5, 6, and 7.

\subsection{Batteile Memorial Instjtute Building KA-3 $3^{(2)}$}

Historically, Baijding KA-3, referted to as the Materials Butlding, was used for variops types of nuclear miterials research prograns for the U.S. Governurient, primarily DOE and tis predecessor agencies. Operations in Bullding KA-3, which is localed in Columbus, Ohio, included a powder metallurgy facility, \& melifcast facility. a rodioactive metallurgy fucility, a ceramics research facjlity, and a sturarium processing facility. While characterization for D\&D of this butlding bezan as carly as 19B6, major Dod $\mathrm{D}$ activities actually began in March 1989 and were completed in February 1995. The beilding has been released for unrestrieted use. The lotal cost of D\&D was approximately \$25 million, not including costs associaled with law-level waste (LLW) disposal.

\subsubsection{Description of Bullding KA-3}

Building KA-3, which was built in 1946, is a two-slory (three floors), rectangular steel frame brick and block structure with a poured concrete ground foox footing and foundation. The grownd floor censibsts of a reinforced concrete slib floor below grade. The elevated Hoors cousist of teinforeed concrete slab floors supported by the structural framework and the foundation walls. The building is divided into six segments by nosth/sonth and easthest hallways with stairwelks on each fiovr. The interior room pertitions are nesimly non-load bearing conktete block walls.
Butlding KA-3 was completed In I947. It was buflt to serve as a nuclear malerals resensh laboratory for the melting. processing, and resesarch of enciched and depleted uranium and tharium isotopes. The building consisted of 191 rooms, over 73,000 square feet, and contained a wide range of equipment.

\section{Genersal Description of Second Foor Rooms}

The second floor of Building KA.3 had approximalely 20 offices; an eightr- room, 2000-sgnase-fool berylinum laboratory; a hot isostatic press developarent labotatory: an arc melt facility iacluding power soppties; and a plasmat spray coating facility. Many of the rooms on the second floor had false ceilings and others had space heaters located in the overhead. A five-ton monorail crane traversed the kngih of the cooms in the middle of the building tom the overtuead door to the inside north wall. Although the crane and some services in the overhead were contaninaled, the area above $\mathbf{2} \mathrm{m}$ on the second floor was generally clean. A floor plan of the second floor of Butlding KA-3 as it was at the beginning of remediation is presented in Figure 3.1.

\section{General Deseriptlon of First Floor Rooms}

The first floor of Boilding KA-3 had approxtmately 15 offices, a ucanium fluoridation laboratory, chemical testing laboratorits, and several targe areas dedicated to the shipping, receiving, and storrage of nuclear muterials. There was also a bod raetalography and polishing thoora. tory that established new cladding properties through the melting and casting of radioactive materials. The traffic and storage areas on the first floor were widely contam:nated within the structure of the building both above and below $2 \mathrm{~m}$ in height. The first floor had a $12 \mathrm{ft}$ by $16 \mathrm{ft}$ rol1-up garage door on the south side of the building that led onto Fifth Avenue ko Jeceive and thip bulk radioactlve material from the vault in Room 25, located near the middle of the building, An $8 \mathrm{ft}$ by $8 \mathrm{ft}$ jarage doar located on the eas side of the building lined up with an 8-ft excridor jpito Building KA-2. This door wis wed for small equipment deliveries and office supplies for Building KA-3. 
Review of Decommitrioning Experience

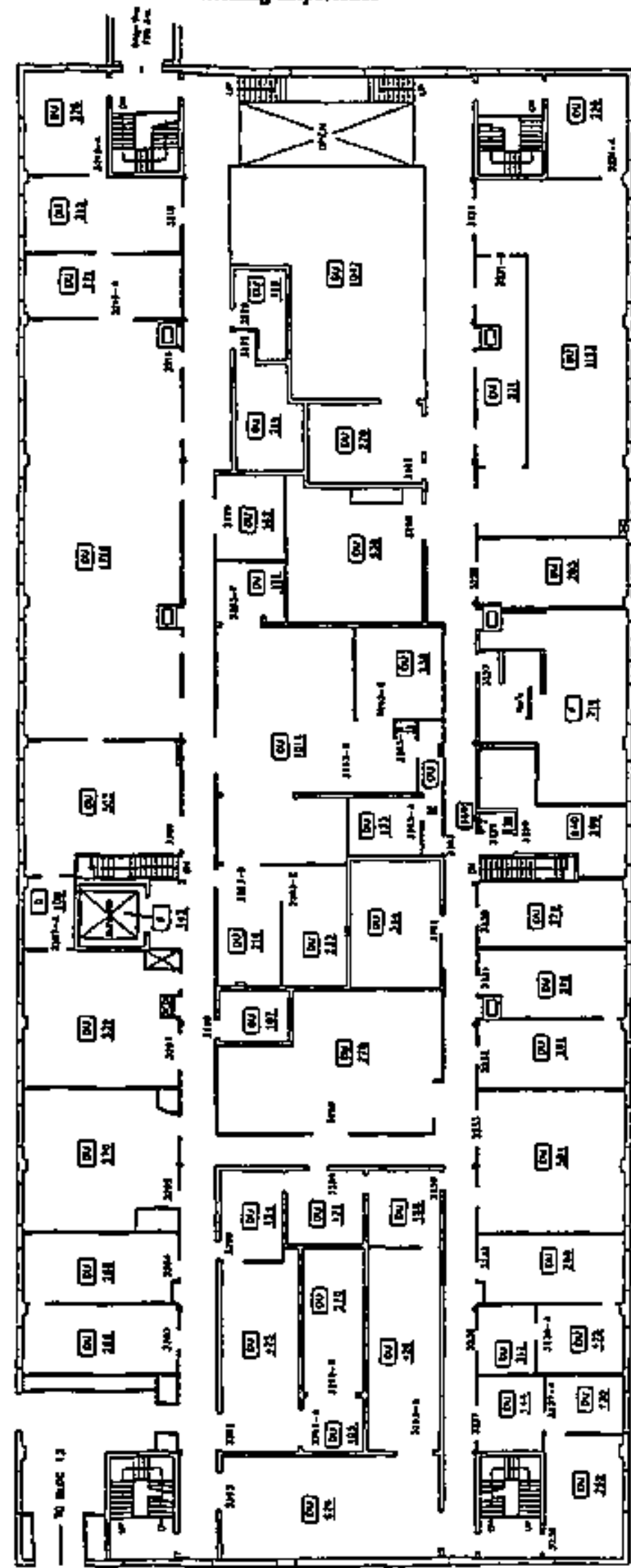

NUREG/CR-6477

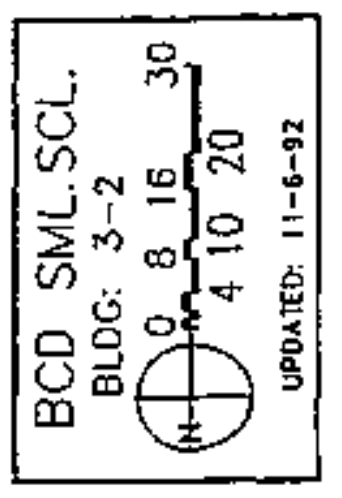

鄫

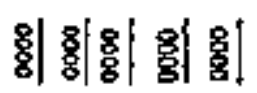

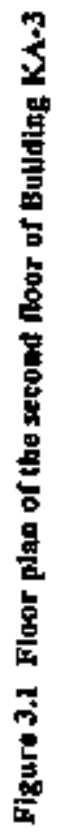

أl

4

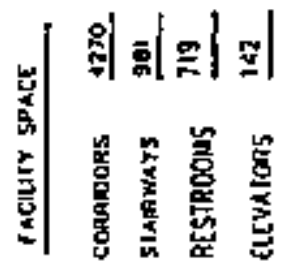


The $12 \mathrm{ft}$ by $16 \mathrm{ft}$ north side garage door was used by Bartelle personnel for Internal shipments. A floor plan of the first floor of Building KA-3 as it was constucted prior to remediation is preserted in Figure 3.2.

\section{General Description of Ground Floor Rooms}

The ground floor of Building KA.3 consisted of approximalely 10 offices, a ceramict laboratory fox sintering uranium dtoxides, a powder metsillergy laboratory, several ${ }^{21} \mathrm{U}$ processing areas, a process drain collection sunnp, a substation, and most of the service headers for the building. This area had a fairly large anount of piping wrepped with asbestos instlation. The northwest side of the ground floor was devoted to wet chemistry work in support of ofher laboratories within Butlding KA-3 and contained fume hoods and conventional laboratory benches. On the north sjue of the goound floor in what was room $3002,{ }^{2 \times} \mathrm{U}$ processing occirred, which necessitued the removal of the entive concrete toor slab. Equipinent ineluded vacuutn furnaces, tsostatic presses, glove boxes, and nachining equipment. Other areas of the ground foor became satellite stordige areas for processing.

From a services standpoirt, the groud floor became the collection poin for the rediosctive drains, water, debris and waste from the other processes. In the latter part of the renediniton wocess, Building KA-3 was found to have a fairly shollow footer system with only s minimal atowint of reinforcement. This condition required modificatians to the building strueture prior to the remediation of the undergound process drain system A foor plan of the ground floor of Bullding $\mathrm{KA}+3$ as it was constructed prior to remediation is presented in Figare 3.3.

\section{General Description of the Contaminated Rooms}

The rooms determined to be contaminaled consisted of painted concrele block walls, cast contrete hoors, and painted concrete ceilings. The flooss were sealted but some of the sealant had wom away. Other areas were biled with asbestos-laden tile. There were drains in the flooxs. Fixed equipment in the rooms included laboratory benches, sinks, furnaces, ovens, presses, lathes, and a variety of other equlpment. Ventilating eir supply ducts were present in eact room Room lighting consisted of several haorescent light fixtures suspended from the ceiling. Electrical condujl, which passed through the roons, was mounted on the walls and supplied pawer to surface-mosunied batlets and the suspended fluorescent lights. In addition, there were severd surface-mounted switch boxes which supplied power vo vartious equipment.

Several I- and 2-inch water tines were suspended near the ceiling. The 2 -inch lines passed through the rooms, and the smaller lines extended into the rooms to supply the laboratory sinks. Some of the 2-inch lines were wrapped with asbestos insulation. Doors, mostly wooden, accompanied each of the 191 roorrs.

\subsubsection{Radiological History}

Direct-reading radiological surveys of lacility surfaces were performed using radliation detection instrumenus. Indirecl radioloticsl surveys (smear sarveys) wete also performed in designated grids showing direct readings above established decision level value (DLV).

\section{Fhoor Drains}

A comprehensive survey was performed on the floor drains in Building KA-3. As a result of drain contamination, the majority of the process drains were removed during the femediation phase of the project. The following is a summary of the contamination detected in the Building KA-3 drains.

Ground Foer (3000 Area). Twenty-five drain samples were collected and found to be contaminated in the 3000 North area. Alpha contamination levels ranged from $13 \mathrm{pC} / \mathrm{g}$ in Room 3065 to $5,990 \mathrm{pCl} / \mathrm{g}$ in Drain 11 , Room 3002B. Btta contamination levels ranged from 18 $\mathrm{pCi} / \mathrm{g}$ in Room 3065 to 4,710 pCi/g in Room 3002. Mercury was also detected in Drain th, Room 3002B.

A 10ed of 66 drain stanples were collected and found to be contaminated in the 3000 South area. Alpha contamioation levels ranged from 12 pCug in Room 3023 to $1,470 \mathrm{pC} / \mathrm{g}$ in the solth drain of Roon 3054. No samples were taken in the shower drains in Rooms 3083 and $3083 \mathrm{~B}$ since these dratins were nol accessible, or in the shower drain in Room 3075 sinet it had been removed. Low levels of mercury were found in drain sarmiles from Rosm 3014. 

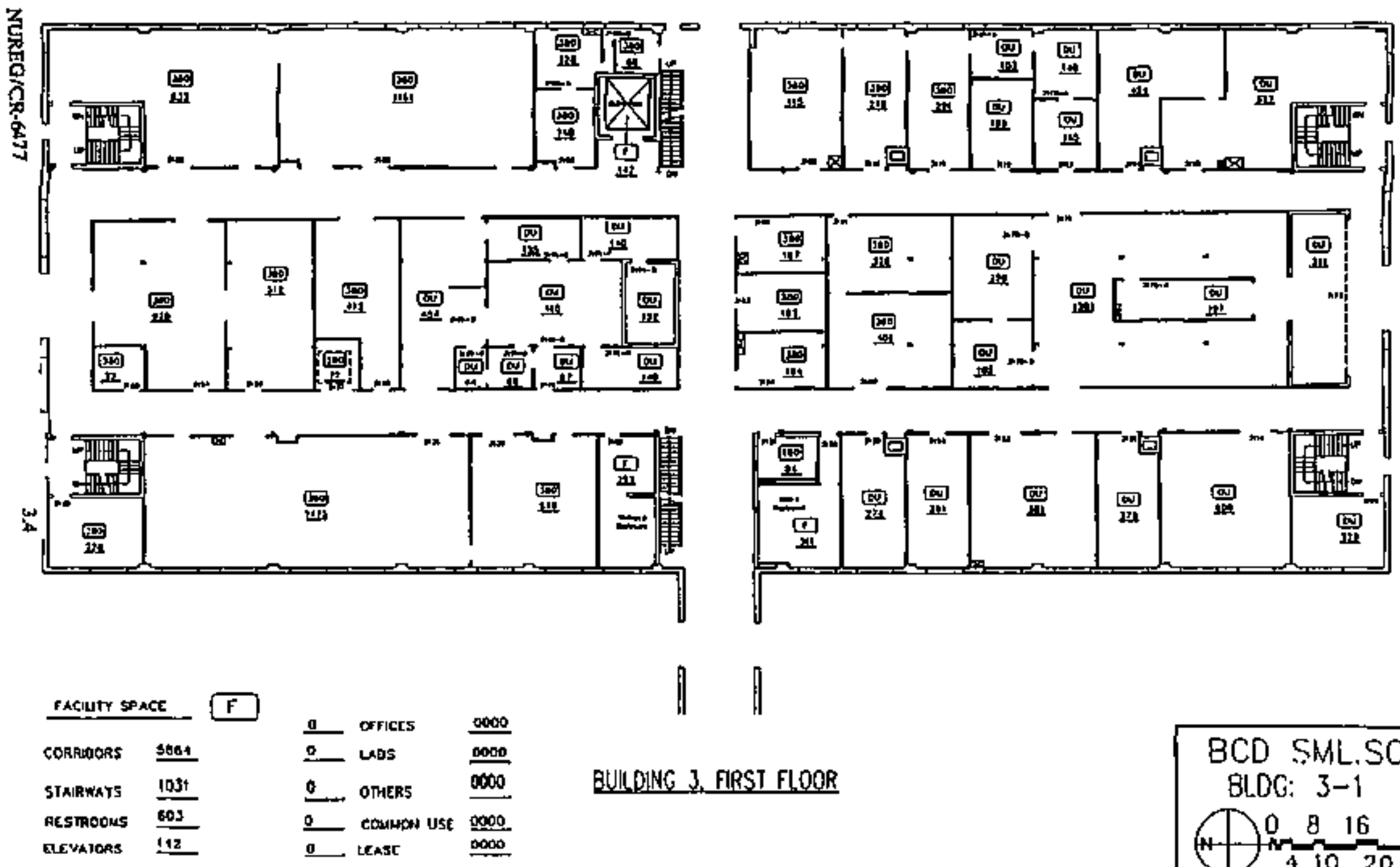

Flgure 3.2 Floor plan or the first floor of Building KA-3

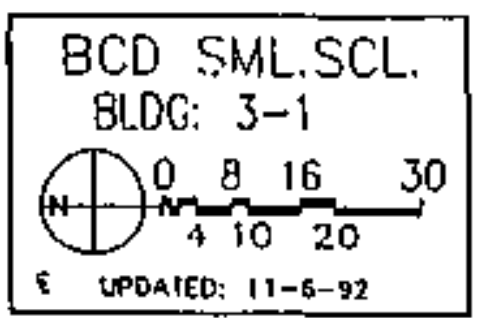

(a) 


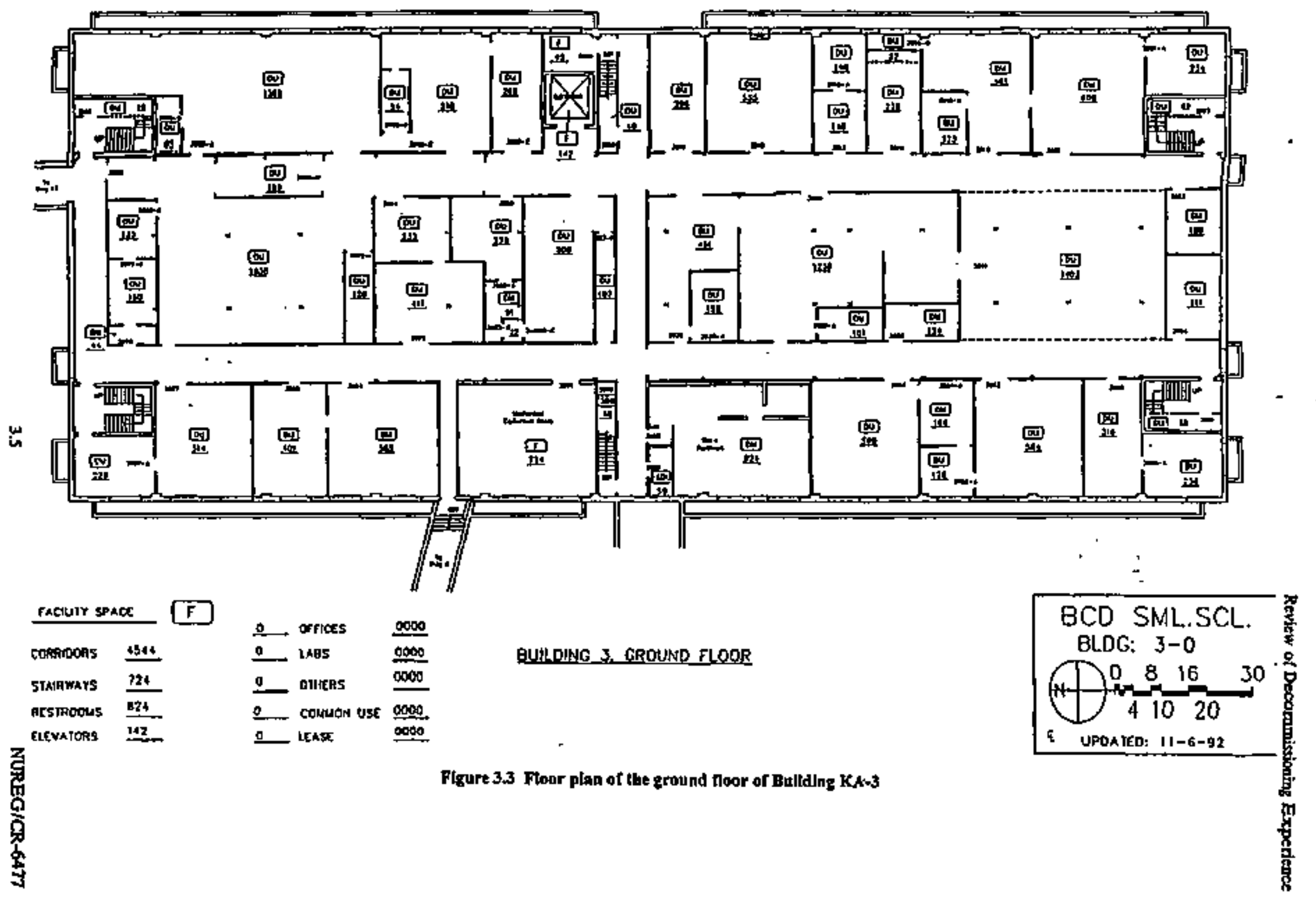


First Flonr (3100 Area). Twenty-five drain samples were collected and found w be contaminated in the 3100 North area. Alpha contamuration levels ranged from 21 pCltg in Drain \#5, Room 3132, to [9,700 pCug in Drain \#I, Room 316L. Beta contamination levels ranged from $7 \mathrm{pCi} / \mathrm{g}$ in the shower drain of Room 3161 to $3,250 \mathrm{pCi} / \mathrm{g}$ in Drain \# I, Room 3161. Mercury was also detected in the northesst drain of Room 3154.

Twenty-eight drain samples were collecied and found to be contaminated in the 3100 South area. Alpha contamination levels ranged from $28 \mathrm{pC} / \mathrm{g}$ in Roorn 3114 to 21,500 pCig is Room 31698. Bets contaminalton levels ranged from $24 \mathrm{pCi} / \mathrm{g}$ in Room 3114 to $21.300 \mathrm{pCi} / \mathrm{g}$ in the center west drain of Room 3169. No rontallological hazarous contaminants were detected in dran samples collected in this area.

Second Floor (3200 Area). Eight draln sitmples were coliected in the 3200 North arei. Alpha contamination levels ranged from $9 \mathrm{pC} / \mathrm{g}$ in Room 3208A to $1,290 \mathrm{pCi} / \mathrm{g}$ in Room 3232. Beta contaniniation levels ranged from $9 \mathrm{pCV} / g$ in Room 3208 $\mathrm{A}$ to $548 \mathrm{pCi} / \mathrm{g}$ is Room 3232. No nonradiological hnzardous contaminants were detected in drain samples coltected in this area.

Thirty drain samples were collecled in the 3100 South area. Atpha contamination levels ranged from $22 \mathrm{pCi} / \mathrm{g}$ in Drain *4. Room 3216, 10 6,490 pCV in the southeast end of the Bay area Beta contamination levels ranged from $19 \mathrm{pCi} / \mathrm{g}$ in Room 3266 10 $15,600 \mathrm{pC} / \mathrm{g}$ in the southeast end of the Bay area. No nontradiological hazardous contarninants were detected in drain samples collected in this area

\section{Collection Pits}

Surveys were performed of the collection piss in Building KA-3. As a sesult, the pits were clearnd and the ditentifled sinks removed. The following is a summary of the contamination found in the collection pits of Bulding KA-3.

Sludge sannples were collecied from five well-iype pits in the 3000 Nonth area and from the main sump for the building. All six samples were found to be contaminated. Net alpha contamination kevels ranged from $154 \mathrm{pCi} / \mathrm{g}$ in Room 3067A to 6,470 pCi/g in Room 30t0. Net beta contamination levels ranged from $82 \mathrm{pCi} / \mathrm{g}$ in Room 3002 to 2,660 pCug in the well in Room 3010. No nonradrofogtcal hazardots contaminanls were detected in drain samples collected in this area.

Thrreen sludge samples were collected from twelve welltype pits in the 3100 Soulh area. Tweive of the thintern sludge samples were found to be contaminated. Nel ajpha conlaminalion levels ranged from $5 \mathrm{pCi} / \mathrm{g}$ to $56,600 \mathrm{pCi} / \mathrm{g}$ in Rooms 3319 and 3114 Nonth, respectively. Net beta contarnination levels ranged from l to JI2,000 pCig, in Rooms 3119 and 3114 North, respatuvely. Mercury was atso found in the sitkk trap of a hood in Room $3 i$ Ig.

\section{HoodsDuctwork/Coavectors/Attached Equipment}

Ventiation hoods and air conditionngheating convector units were surveyed as part of the characlerization efforts. Hoods and wentilation units that were radioactively contarrinated were removed and disposed of as radicactive waste, Hoods in Rooms 3065, $3158,3263 \mathrm{~B}, 3263 \mathrm{C}$, $3263 \mathrm{E}$, and $3263 \mathrm{~F}$ were not surveyed since they were inaecessible. The interior of inactve ventiflation hoods and equipment ductwork was surveyed by direct and indirect mont1oring methods, most often at disconnecled hook-lp functions. Soldd material samples were collected front ductwork interiors, when possibte.

Six single hoods, three double hoods and associated ductwork, and ductwork on three equipnent items in the 3200 North area were tound to be combaninated. The maximum net alpha direct reading was $7,370 \mathrm{dpm}$ $100 \mathrm{~cm}^{2}$ on top of the hood in Roorn 3232. The maximom net beta direct reading was $69,800 \mathrm{dpm} / 100 \mathrm{~cm}^{2}$ inside the hood in Roon 3293. All heating/air conditioning convector units were contaminated with net beta activity levels ranging from $1,370 \mathrm{dpm} / 100 \mathrm{~cm}^{2}$ to $12,700 \mathrm{dpm} 100 \mathrm{~cm}^{2}$. Several pieces of large equipmemt such as dry boxes, hydraulic presses, metal cabintes, and miscellaneous items were identified tuher by direct measurements or by posted informaton as being contaminated.

Five hoods and 31 ductwork sections in the 3200 Soulh area were delected to be contarninalod. The maximun net alpha direce reading was $], 320 \mathrm{dpm} 1100 \mathrm{~cm}^{2}$ in the ductwork in Room 3218. The maximalm net beta direct 
reading was $49,500 \mathrm{dpm} / 100 \mathrm{~cm}^{2}$ in the center vemt of the hood in Room 3054. Maximum removable contamination levels were $329 \mathrm{dpt \pi} / 100 \mathrm{~cm}^{2}$ net alphas and $235 \mathrm{dpm}$ $100 \mathrm{~cm}^{2}$ net bets. These were defecled in Rooms 3054 and 3112 North, robpectively. Several pieces of large equipment such as diy boxes, hydraulic piesses, metal cabinets, and miscellaneous itens were identified eilher by direct measurements or by posted information as being contaminated.

\section{Roor}

Roof-1op gravel samples were coltected from 29 locations on the north roof. Thuee samples bealed on the northesst and soubwest comers of the north cemier roof exceeded the background levels of $49 \mathrm{pCi} / \mathrm{g}$ alphz activity and $50 \mathrm{pCi} / \mathrm{g}$ beta activity. The net alpha extuvities of these samples were 47,43 , and $45 \mathrm{pCi} / \mathrm{g}$, respectively. During rernediation, all contaminated surfaces were cleaned by removing the comaminated malerial. The ductwork interior from four laboratory bouds was also determined to be conteminated. These four duclwork locstions were on the noof over Room 3204, Room 3205, Room 3206, and Room 3293. Net alpha activily levels fanged from $94 \mathrm{dprz} / 100 \mathrm{~cm}^{3}$ (Roorn 3204) to $756 \mathrm{dpm} / 100 \mathrm{~cm}^{2}$ (Roosu 3206). Net beta getivity levets ranged from $2,139 \mathrm{dpm} / 100 \mathrm{~cm}^{2}$ (Rooms 3204 and 3205) to 19,219 dpril100 $\mathrm{cm}^{2}$ (Room 3206).

Direct beta measurements were taken inside and outside of seven tisers, 60 hood/hood vents, and three chimneys on the south roof. Of these 140 measurements, only three exceeded ate derived limit vatue (DLV). These three Jreasurements were located inside the bood in Room 3010, inside the cap of the hood in Room 3178, and inside the cap of the hood in Room 3t19. Net beta ssurface contamination levels ranged from 1,5to dpm/ $100 \mathrm{~cm}^{2}$ to 9,200 dpnV/100 $\mathrm{cm}^{2}$. No alpha activity associated with these measurements was detectable above background levels. Sinearable contarnination associated with these metsurements ranged from minimum delectable actlvity (MDA) $109 \mathrm{dpm} / 100 \mathrm{cer}^{2}$ for thet alpha activity and from MDA to $13 \mathrm{dpm} / 100 \mathrm{~cm}^{2}$ for net beta activity.

\section{Surfaces}

The coataminated surfaces of Building KA.3 were als remediated in accondance with the release criterin established for the building. In conjontion with the finat survey of Building KA-3, the exterior suffaces of the building were also gridded and verified to have contamination levels below MDA.

Ground Floor (3000 Ares). By ertablishing a total of 594 floor grids, characterization of the 3000 area (ground floor) foors of Building KA-3 decermined that 54 rooms were contam'nated. The highest drest survey readings were 7,650 dpurllo0 $\mathrm{em}^{2}$ net alpha activily and $166,000 \mathrm{dpm} / 100 \mathrm{~cm}^{2}$ pet beta activily. Maximum removable contarnination levels were $6.54 \mathrm{dpm} / 100 \mathrm{~cm}^{2}$ net alpha activity and $803 \mathrm{dpm} / 100 \mathrm{~cm}^{\prime}$ net beta activity. A total of $594 \mathrm{~m}^{2}$ of floor area was determined to be contanizated.

Characterization of the Building KA-3 3000 area watls below $2 \mathrm{~m}$ in hejght determined thal a total of $75 \mathrm{wal}$ grids in 28 rooms were contaminated. Highest direet survey readings were $1,900 \mathrm{dpm} / 100 \mathrm{~mm}$ net alpha activity and $73,800 \mathrm{dpm} / 100 \mathrm{~cm}^{3}$ nes beta sctivity. Maximum jemovable levels of cantaninalion were $269 \mathrm{dpm} / 100 \mathrm{~cm}^{2}$ net alpha activity and $39 \mathrm{dpm} / 100 \mathrm{~cm}^{2}$ net bets activity. A toeal of $75 \mathrm{~m}^{2}$ of will surface area was determined to be conlaminated

Charmcterization of the harizontal surfaces above $2 \mathrm{~m}$ deternined that a total of 77 wall gids in 20 rooms were contsminated. Highest direct survey readings were

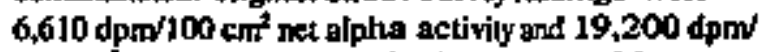
$100 \mathrm{~cm}^{2}$ pet beta activity. Maximum removable contannination levtls were $139 \mathrm{dpm} / 100 \mathrm{crt}^{2}$ net alpha activity and $232 \mathrm{dpm} / 100 \mathrm{~cm}^{2}$ net beta $77 \mathrm{~m}^{2}$ of horizontal surface area above $2 \mathrm{~m}$ was determined to be contaminated.

First Foor (3100 Area) Floors. Characterization of the 3160 area of Building KA-3 delermided that a total of 549 floor grids in 52 rocons were comiminated, Highest direct survey readings were $33,200 \mathrm{dpm} / 100 \mathrm{~cm}^{2}$ net alpha activity and $191,000 \mathrm{dpm} / 100 \mathrm{~cm}^{2}$ net beta ectivity. Maximum renovable contamination levels were 1,300 oppr'100 cmin' ret alpha activily and $138 \mathrm{dput}$ $100 \mathrm{~cm}^{2}$ net bela attivity. A total of $594 \mathrm{~m}^{2}$ of floor area was deterntined to be contaminated.

Characterization of the 3100 anea wals below $2 \mathrm{~m}$ of Buitding KA-3 determined that $a$ total of 161 wall grids is 28 rooms were contaninated. Highest direct survey 
readings were $13,500 \mathrm{dpm} / 100 \mathrm{~cm}^{2}$ net alpha axtivity and $32,260 \mathrm{dpm} / 100 \mathrm{~cm}^{2}$ net bets activily. Maxirnum remov. able contanunation levels were $763 \mathrm{dptw} / 100 \mathrm{~mm}^{2}$ net alphs activity and $534 \mathrm{dpm} / 100 \mathrm{~cm}^{2}$ net bets activity. A lotal of $161 \mathrm{~m}^{2}$ of wall surface area was delermuned to be contamunated.

Characterization of the horizontal surfaces above $2 \mathrm{~m}$ determinned that a total of 92 wali grids in 19 tooms were contaminated. Highest direct survey readings were $46,500 \mathrm{dpnv} 100 \mathrm{~cm}^{2}$ net alpha activity and $63,300 \mathrm{dpm} /$ $100 \mathrm{~cm}^{2}$ nex beta activity. Maximum removable contaminstion levels were 2,350 $\mathrm{dpm} / 100 \mathrm{~cm}^{2}$ net alphn activity and $277 \mathrm{dpm} / 100 \mathrm{~cm}^{2}$ net beta aclivity. A 104al of $92 \mathrm{~m}^{2}$ of horizontal surface area above $2 \mathrm{~m}$ was determined to be contaminated.

Second Fhoor (3200 A rea) Floors. Characterization of the 3200 aren of Bujidting KA-3 determined thas $a$ total of 421 foor grids in 49 rooms were contaminaled. Highest direct survey readings were $7,380 \mathrm{dpm} 100 \mathrm{~cm}^{2}$ net alpha activity and 73,800 dpm/100 $\mathrm{cm}^{2}$ net beth activity. Maximum removable contumination levels were $90 \mathrm{dpm} /$ $100 \mathrm{~cm}^{2}$ net alpha acivity and $58 \mathrm{dpm} / 100 \mathrm{~cm}^{2}$ net beta activity. A lotal of $421 \mathrm{~m}^{2}$ of floor ares was delemined to be contaminaled.

Characterization of the 3200 area walks below $2 \mathrm{~m}$ of Building KA-3 determined that a totol of 57 wall grids in 18 rooms were contarninaled. Highest direen survey

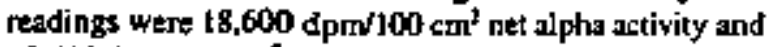
$17,500 \mathrm{dpm} / 100 \mathrm{~cm}^{3}$ net beta activity. Maxímm nemovable contamination levels were $492 \mathrm{dpm} / 100 \mathrm{~cm}^{2}$ net alpha activity and $78 \mathrm{dpm} / 100 \mathrm{~cm}^{2}$ net beta sctivily. A tolal of $57 \mathrm{~m}^{2}$ of wall surface area was deiemuned to be contaminated.

Characterization of the horizontas surfaces above $2 \mathrm{~m}$ determined than a total of 39 wall grids in 20 roonss were contariminated. Highest direct survey readings were $1,840 \mathrm{dpm} / 100 \mathrm{~cm}^{2}$ net alphe activity and $17,700 \mathrm{dpm} /$ $100 \mathrm{~cm}^{2}$ net beta activity. Maximum removable contamination levels were $112 \mathrm{dpm} / 100 \mathrm{~cm}^{7}$ net alpha activity and $15 \mathrm{dpm} / 100 \mathrm{~cm}^{2}$ net beta activity. A total of $39 \mathrm{~m}^{2}$ of horizontal surface area above $2 \mathrm{~m}$ was determined to be contianunated.
Soll

Forty-six samples were collected from 10 locations beneth the ground floor of Bullding KA-3. Holes were cul in the concrete floor of the ground floor ievel, and holes of varying depths were cored in the soil beneath the floor. Samples ranged in depulh fon the surface (directly under the floor) to 85 inches below the floor level. The samples were analyzed for gross alphas and gross beta aclivity. Two of the sample locations were approximately 30 feet from the dratn lines, and the radiosnalytical results were used to represent the soit background. Background samples were calculated to be $23 \mathrm{pCi} / \mathrm{g}$ alpha and $22 \mathrm{pCV} g$ beta activity.

The results of the garmma spectroscepy show that net alpha activity greater than backgraund concentrations oocurred in 22 of 45 samples, and the bela activily greater than background concentrations occurred in 19 of 45 samples. Uranium-235 concentrationts ranged from MDA to $5 \mathrm{pCl} / \mathrm{g}$. Activity levels in the vicınity of the bell fitlings connecting the drain sections were generally higher than those aiong the length of the pipe. Gross alpha activities ranged from $11 \mathrm{pCi} / \mathrm{g}$ to $184 \mathrm{pCV} / \mathrm{g}$ at the betl connectors in the ground floor and Room 3002B (north), respectively. Gross beta activilues ranged from $15 \mathrm{pCig}$ to $83 \mathrm{pCi} / \mathrm{g}$ at the bel! conaectors in the ground floor and Room 3016, respectively. Analysis of the dati indicated that radioactive contamination in the sol likely restilted from the release of radioactive materials Irom the drain lines, probably at the bell filluggs.

Since conlamination was found in the soil inside the footprint of Building $\mathrm{KA}-\mathbf{3}$, representative soil samples were taken on the exterior of the building. All results from these samples were below MDA.

A sample of soil from Room 3016 was analyzed for Toxic Compound Leaching Process (TCIP) Extractable Metals and showed concentrations of Ba st $0.32 \mathrm{mg} / \mathrm{titer}$, Cd at $0017 \mathrm{mg} / \mathrm{liter}$, and $\mathrm{Cr}$ at 0.012 mgliter, $\mathrm{As}, \mathrm{Pb}, \mathrm{Hg}, \mathrm{Se}$, and $\mathrm{Ag}$ were not detected. When the soil and drains were removed during the remediation process, however, nine of the 309 cubic yards of soil were determined to be contaninated with uranium and thonum. A considerable quantity of $\mathrm{Hg}$ (mercury) was found outside the drain 
conrections in the sumounding soil. The mercury was remedialed by aspindion and removal in-situ. The soil was verifít cleath.

\subsubsection{Release Criteria}

The radiological ralease criteria established for this building were approved by both the DOE and the NRC. These criteria are based upon the accerptable residual surface conlaminntion levels for wrestrictod release defined in DOE Order S400.5, "Radiation Protection of the Putlic and the Environment," and NRC Regulalory Guide 1.\&6, "Ternination of Operating Licenses for Nixclear Reactors." As discussed in Section 3.1.2, most of the rooms in Bulldhing KA-3 had measured contarrinstion kevelg above these guideline relcase linits: therefore, a resonable amount of decontamination effort was requined before neleasing the building for use without radiologicai restrictionș.

\subsubsection{Summary of Building KA-3 Decontamination Activities}

The overall decomntissioning aclivities for Building KA-3 were guided by general requituments docutnented in a Quality Assurance (QA) Plan, a Decommtstoning Work Ptan, and specific operexing procedures. The contamiration was pot widespread and radiation levels were low. Thus, the chief concem was not the radiation level but wather the control of the spread of the contanination and the danger from inhalation of ariome particulates duriog the deconiamingtion effort.

The overall segance of D\&D activities was carried out as follows:

(1) Enginecting and Preparation.

(2) Removal of Laboratory Chenticals, Strvices, and Equipunert.

(3) Decontamination of Surfaces, Services, and Equipment

(4) Final Radiaion Surveys.

(5) Independent Verification Survey.
(6) Restoration of the Facility.

(7) Radioactive Waste Management.

Engineering and Preparation

The Engineering and Preparation efforts for the D\&D activities were conducted as follows:

(1) Trainizig of D\&D workers.

(2) Installation of a staging area for handling and interim packaging of contaminated waste for transfer to the central staging area in Butlding KA-2.

(3) Selection of D\&D equipment.

(4) Installation of control barriess.

Traibling Dad Workers. Training included targeted training in the specific procedures to be employed and refseshur training in radiological and occupational sofety. Each worker assigned to perform a specific activity was fully trained and qualitied to perform the assigned D\&D activity.

Installation of the Stanging $A$ itu, The fanction of the staging ares was to conirol the spread of contamination from the D\&D rowms, to poovide facilities for personnel to change clothes when entering and lesving the D\&D area, and to provide areas for local waste packaging operations. In Building KA-3, there were several staging areas within the building at any given tine so that multiple crews of workers could perform work simultomeously.

The staging area isolated the D\&D area from the rest of Butlding KA-3. Within the staging ares, "clean" and "contaminated" change areas were established for use as personnel entered and left the work areas undergolng deconamination. Facilities were provided at this location for mainlagical surveys of personiel leaving the area. The staging arva also included an tititial packaging area so that waste could be properly packajed for transfer to the waste handling area in a separate brikling. The most feasible location for the staging area was determined to be in the main corridos atong the actess bartiens of the building and ot the acoess areas berwero the floors. 
Selectlon of D\&D Equipnent. This axtivity identified the types of equipment that were specifically required for use int the remediation process. The lisi of D\&D equipment used included vacuum blasters, scabblers, containment enclosures, strippable paints and solvents, chenry pickers, manlifts, concrete cutters, core dnlls, rock dalls, grout pumps, backhoes, on-site radiological stipport, culling torekes, and hand lools. Support equipment included air monilors, radiological survey meters, waste containers, prolective clothing, air purifying respirators, bubble suits, radration scanners, and personal dosimelers.

\section{Installation of Control Barrier}

Access cottrol barriers were instalted to isolste the D\&D areas. Physical barriers such as cemporary walls, plywood batiers, doors, locks, and alarms were used. Proninent signs designaled locations as a D\&D operation areas. Afier access control barriers were installed, the contaminalion control bamers and staging areas were established so that they feil within the confines of the access control barriers.

During installatron of contamenation control batreers, air in the D\&D area was contizuously monitored. The air was not recirculated in onder to eliminate the potential for introducing arborme conlamination from other paris of the bujlding ines the clear areas. Instead, the air was exhausted on the first floor by two large HEPA units. The contanination control barriers were either erected at normal room openings or were erected to the main corritors, fividing the floors inlo six sections.

\section{Removal of Chemikals, Services, and Equipment}

The sequence for removing labocatory chemicals, servicts, and equapment for D\&D actinties was as follows:

(i) removal of laboratory chenicals

(2) removal of services

(3) renoval of equipinent.

Removal of Leboratory Chemicals. The removal of laboratory cheritcats from tho bulding first played a key role in the overall D\&D effort. Since the butilding tad many laboratories and the research was quite varied, there were many different kinds of chemicals present. By ulilizing the remanning operations and waste management personnel trained in hazardous wasle the dedicated D\&D personnel did not have to be trained for or be exposed to the latge variety of chemesals. Penodically, monitoring for chemicals was conducted in the event that there could be significant residual chemicals presem. However, problems did not arse in Building KA-3. The major chenucals encounlered in the D\&D process were lead in the paint at limes and mercury in the drain lines.

Removal of Services During the D\&D process, the removal of laboratory stervices such is water, gas, and air was necessary in onder to access the wall, ceiling, and tloor surfaces. Some services were tracressible without first removing equiptnent. Electrical power to each noom and area being decontaminaled was lefic connected as long as possible to faciltate the use of powered D\&D equipment. Likewise, the common servees in the building were left intact to accommodate heat, fire service, and electrical distribution systems. As the D\&D activites progressed and these services were affected, the services for the roons and areas were ejther disconnected of rerouled to accommodate the D\&D process.

Remioval of Equipment. The process of removing equipment was slightty more involved than initialty anticipated. During the D\&D process, the removal of equipment was necessary in order to axcess the walt, ceiling, and floor surfaces. However, during the removat. determinations had to be made as to the equipment's disposition. If the unit was radioacuvely contaminated, it was determined to be Low Specific Activity (LSA) Wasle, Mired Waste, or TRU Waste. If the unit was not radionctively contaminated. it was deternined to be reusable, sellable, hazardous waste, or trashed. Since these delerminations had a beanng on how the unit would be removed, systematic planning for the D\&D and removal of equipment was mide.

\section{Decontamlantion or Surfaces, Services, and Equipment}

The sequence for decontamination of surfaces, services, and equipment was carrled out as follows:

(I) survey of the exposed surfaces

(2) removal of the attached equipment and services

(3) decontamination of the stairways and comtmon areas 
(4) decontarminatios of the foor drains

(S) decontanination of the floors, ceilinges, and walls.

Survey of the Exposed Surtoces. The first activity implertented in this seguence was surveying the expased surfaces so that the extent of decontaminalion efforts could be assessed. In Building KA-3, it was determined that the walls up to a height of $2 \mathrm{~m}$ needed to be decontaminated and that the cetting was virtually clean. Minor comarsination was detected on the horizontal beans of the ceiling and on services along the ceiling but these surfaces were easily cleaned. There was, however, one laboratory that had served as a beryllium research area that had to be completely remediated.

Remaval of the Attached Equipment and Services. The removal of the attached equiprnent and services was an important step since most of the equipnent was contaminated and the walk and floors behind the equipotenk were inaccessible. The eguipsment. which included hoods, sinks, benches, atc., was monitored and removed to the Waste Management Area for packaging. The major service conterns involved the ductwork that tan between the ftoors of the building through openirgs called penetricions. After surveying, the contarninated dustwork was capped on the botton floor, removed through the peactration and the penteration deconlarinated. Although some af the bujlding ventilation was contaninated on the autside within the flowrs of the buidinge, the building vemilation system was nod requined to be removed. The common services in the bujlding were remained contrected to accommodale heat, fire service, and electrical distribution systems.

Decontaminalion of the Stairways and Combond Artas. The surfaces of stairways and common areas were decontarnizited by scrubbing, washing, andor gris blasting with a HFPA filiered vacuutum Afier all contarnination was removed, barriess were installed to limit access to the clean areas and provide contamination control between the floors of the building.

Decontaminathos of the Floor Drales. Rernoving floor drains was a \$lightly more involved process than initially monicipated. Mencury was discowered in prany of the drains; therefore, the drains had to be carefully disassenbied joix by joint and wrapped for processine. They were thes transported to a controlled area where they were honed, packaged, and disposed of property.
Furthermore, drain lines beneath the ground floor had keaked, causing redioactive and menesry contaminstion in the soil. This soil was removed for disposal, whtch first required removal of large sections of the basement foor. Because the basement floor also served as foundation suppor for the building. the foundation soil required strenglhening in order to support the building. This sinengthering was achieved via in-situ grouting of the soil.

Deeontanlnation of the Floors, Cellings, and Wills. The results of characterization surveys showed that the concrete floors and lower walls were contarninated. A dry process mechanical grit btaster with a HEPA vacuum was used to remove surface layers from the concrete floors and walls up to $2 \mathrm{~m}$ high. Several passes were required in some areas afler which the intermediate radiation surveys showed that the residiag contamination had been removed and that the floors and walls were at or below background levets.

In some instances, the contamination had seeped deeply into the concrete through cracks. In these cases, the contamination was removed by chipping out the contaminated concrete using a pneumatically operaled chisel or maul point.

\section{Flaal Radlation Survegs}

The effectiveness of the decontarination operations was determined by ractiation surveys. "Interim" surveys were used during deconiamination activales vo determine whether further actions were requirad. The term "interim" was used to distinguish them from the pre-D\&D surveys (characlerization) and from the post-D\&D surveys (finsl status surveys) that provided the data that indicated decontamination was conplete. The final surveys were conducted in concurnence with plans and procedures and were the tinal step taken to assure a saltsfactory level of remediation was performed on Building KA-3. The building was then sealed and controlled pending the independest verification survey.

\section{Indeperdent Verifieation Survey}

After oll contaninated ereas were cleaned and monitored, the Independent Verification Contractor (IVC) conducted a servey to verify the edequate removil of residual contantination from Building KA-3. Results of this 
survey indicated that contamination levels on floors, walls, and ceilings were well below acceptable timots for relense of the building for use withous radological restrictions.

\section{Restoration of Huilding KA-3}

Restoralion was initiated after all contamination had been removed and the independent verification survey found no remaining areas where adjilional decontamination would be required based on the ALARA guidelines. This restoration sequence is expected to be typical of the refurtishment efforts of any older facility and no unique sequencing problems were anticipated.

\section{Radionctive Wasto Mrragement}

Throughout the decontamination optration, beginning With the removal of the laboratory chemucals and ending with the removal of the last traces of contamination, low level waste was generated. All contarinaled materials were bagged in plastic and placed in transfer contanners. The containers were transported to anoher bulding for characterization and final packaging of the waste for shipment to appropriate disposal sites.

These operations were performed in accordance with the applscable waste management procedures, which fulfill the requitements of the low-level waste certification plan and the waste management QA plan.

Waste Management Goidelines. Most of the radipactive waste generaled during $D \& D$ of Building KA3 was sent to the Hanford site for disposal or storige. Wastes were segregated by radioactive material content, physical form and chemical conient:

- Radioactive Malerial Content - low-level wastes (LLW).

- Physical Forma - Wastes were further segregated by physical state as follows: (I) solid malemals, (2) liquids, (3) absorbed liquids, (4) organic luquids. (5) biotogical waste (6) gas (7) high-efficiency particulate filters, (B) resins, (9) sludges, and (10) lead waste from lead shielding.

- Chemical Content - Wastes were segregaled by DOT hazand class \{c.g., oxidizer, flammable liquid. flammable solıd, acid, caustic, poison) and tracked by the following (I) U.S. Nuclenr Regulatory Commssion's (NRC) shaliow-land burial classes (i.e., A, B, C. and C+) and (2) specific wasle categories as they becarne defined.

These requirements were imposed on every activity in the waste management program. Some metals and compactable wastes were shipped to Scientific Ecotogy Group, Inc. (SEG) for processing. If the melals qualified, SEG melied them for overnl] size reduction. [ikewise, the compactable wasles were either incincrated or supercompacted depending on waste cost factors. Bulk waste and somx mixed waste was disposed of at the Envinocare disposal faciliry in Utah.

Waste Transfer atd Interim Storage. The D\&D Work Plan for Butlding KA-3 envisioned ore central waste staging area to handle all waste from Building KA-3. The location was in a separate bulding where a sujtable enclosed shipping area aiready existed.

In lerms of waste management, the central staging area was where atl the required certificalion measuremems for toarsport were taken. It is also the place where waste fiom Building KA-3 was stored in the interim until sufficient waste had been accumulated lo make up a waste shipment. Bectause of the segregation requirements imposed for waste acceptarxe at the disposal facility, any sorting and repackaging was perforned at this staging area.

Waste Characterdzation. Upon arrival in the staging area, the transfer contanners were opened and the contained waste was monitored is detail. The material was inventoried and surface readings were reconded. This became part of the shipping documentation characterizing the package. Gamma-ray isotopic aralysis of samples from the waste showed that the proncipal isotopes were ${ }^{23} \mathrm{U}$ and ${ }^{2} \mathrm{U} U$ with same thorium. Fron this cata and the 10tal volume of waste, the total actinty of the packaged waste from Building KA-3 was determined.

Waste Volumes and Volume Reductlon. The waste recervad from Building KA-3 was reduced in volume maisly by decontanunating the draist and manually corshing the wasle, particularly the suspect plastics. Most 
of the waske could not be decontaminaled and was packaged as LLW, The onter miscellanoous conpactible wasues such as paper suits, gloves, and othes iterns were compacied. A total estimated waste vohume from D\&D activities is not avaitable because LLW generaled was included with LWW generated from the D\&DD of other butldings on the Battelle-owned site.

However, more than 8,000 $\mathrm{tt}^{\prime}$ of condarinated sub-floor sotl was excavaled to remove more than 3,000 linear feet of contaminated drain lines.

Waste Packate Certification. In order to moet the package requirements for acceptance of the D\&D wasle th the dxsposali site at Hanford, the D\&D wasle from KA-3 had to be classified and the package certifted for shipanent. The waste package datio included the principal radiouctive elements in the package, Jisted by isotope; the activity level, in curies, of each isotope; the physical form of the saaterial; and the specific activity of the quiterials in the shipmenl in mikcocurjes/gran for solids. The waste package wis certified acceptable to meet the requirtments of the disposal sile in accordance with the proposed LLWW certification ptan for safe interim storge of the waste at Hantord.

\subsection{Hoffmann-la Roche, Inc. Medi-physies Cyclotron Facility ${ }^{(3,4)}$}

Thìs Iatility, kacated tn Nutley. New Jersey, conkined a 22-MeV cyclotron used in the mantaftche of tadiophartraceuticals from about 1968 through 1984. In 1984, the cyckotron was shut down and decommissioned. Il was sold in 1985. A vendor was coniracted to remove radioactive concrete from the inater serface of the concrele vaple used to houste the cychotron and provide a madtation stiteld. The imtent was to remove suffictent contrete to allow the remainder of the valt to be disposed of as nonredioactive industrial waste. For a variecy of rezsons, fins D\&D of the faclity was not iniliated until March 199!; the radianctive materials license was teminated in Jone 1991.

\subsubsection{Description of the Facility}

The cyclotron vealt was localed within a warkonse which, in twrs, whs located within a building oceupied by other companies. Altached to the exterios of the concrete vault were six rooms made of contrete block walls. After removal of the cycktron, the vauli wis used as a storerowm that had en accumulation of ofd tumiture, lumber. production supplies, wood and metsl chinets and shelves, small electrical parts, empty nodroactive waste containers, and concrete-fiped steel drums.

A predeconumissioning inspection of the warehouse revealed a factlity that apparently bad been vacated in haste. Discovered during this inspection wert:

- office furniture in an extreme slate of ill-repair and disarmay

- Laboratoxies full of glassware, chemócals, electronic equipmetil, sefrigterators, and lead shieldinis of various sorts

- a car in the wanthouse section with a fat tire, broken window, and lhick coating of crud

- a wide variely of hazadous waste including partialy used batties of propanol, acetont (and other solvents), brake fluid, oil, terpentine, acids, used crankcase oil, transmisston flotd, elc.

- old unwanted periodicals, joursals, books. and stationery

- unsecured gas cylinders of various sizes and contents (HCL nonrsdiosctive xenor, actylene, nitrogen, etc.)

- asbestos floor liles and laborany benches

- fluorescent light fixlures containíng PCBs

- B large steel safe used for storage of computer records

- wood and metal cabinets and shelves

- concrete-dined steel drums

- telephones connected through a service board somehow tiod also to the facility next door

- many stoxage containers and waste cans brightly 
labeled with redioacuve material waming labels.

\subsubsection{Radiological History}

A radiatıon survey was performed in the cyclotron vault in Oclober 1986. In addition, concrete cone samples laken in July 1985 were sectioned and scanned to obtain the radicisotopic composition as a functron of depth in the concrete. The results of these analyses were as foilows:

- exposure levels in the vastl fanged from 130 to $425 \mu \mathrm{Rhr}$

- background levels outside the vault were about 10 sh hir

- Lhe hotest areas in the vault were the floor and ceiling near the center of the room

- the radioisotopes measured in the concrete were ${ }^{6 n} \mathrm{Co}$, ${ }^{152} \mathrm{Eu},{ }^{15 *} \mathrm{Eu},{ }^{134} \mathrm{Cs}$, and ${ }^{40} \mathrm{~K}$

- ${ }^{60} \mathrm{Co}$ and ${ }^{15} \mathrm{Eu}$ made up about $92 \%$ of the total activity in the concrete

- ${ }^{60}$ Co activity was about $10 \%$ higher than that of ${ }^{157} \mathrm{Eu}$ in the concrete

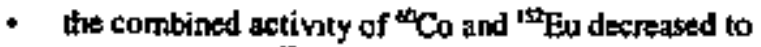
the background ${ }^{* 0} \mathrm{~K}$ activity in the concrete at a depth of 13 inches

- the back grourd ${ }^{40} \mathrm{~K}$ activity was fairly constant at $12.4 \mathrm{pCi} / \mathrm{g}$ average

- $90 \%$ of the induced activity in ube concrete was in the firse 12 inches

- the specific activity in the rebar in the conerete was about three to four umes that of the concrete in the samin ares.

\subsubsection{Summary of D\&D Activities}

The first step is decommissioning the cyclotron facility was to remove alt of the resioulual debris described previously. Al af the gas cylinders were retrieved by an
Industrial gas firm A contractor was hired to classify, segregate, package, and ship all hazardous material for proper disposal. Clean laboratory glassware was packaged and donated to a high school for reuse. Other debris in the warehouse and wault were reurieved, surveyed for radioactivity, and frec-released for disposal. Idenlified radioactive waste was packaged and disposed at the Barnwell LLW disposal site.

Based on the radiological survey of the facility described previously, the following D\&D plan was developed:

(1) Perfomm on-site baseline radiological surveys.

(2) Remove aboul 12 inches of radractive concrele from the inner surface of the walls and floor, package the rubble in steel boxes, and ship to the Bamwell LLW sile.

(3) Radiologically survey the vault at a 1 m distance and achieve a $56 \mu \mathrm{R} / \mathrm{hr}$ level; oblan regulatory approval 10 fres release the remainder of the vault.

(4) Demolish the remainder of the vault from the oulsłde.

(5) Radıologically survey each bstch of concrele as a QA step before it is shipped to an industriat landfill.

(6) Perform final radtological surveys of the facitity after the vault has been removed.

(7) Pour a new concrete floor in the hote created by Itrmoving the vault floor.

(8) Teminate the radiosctive material license.

The 12 inches of radioactively contaminated concrete were removed from the floor and walls using a remotecontrolled hydrolic hammer. Rebar in the floor was cut using torches. The vautt was then painted into a grid pattern with I m squares, and a complete radiation level survey was conpleted using throe hand-held instruments. All three instruments were within $10 \%$ and reading an awerage of $\mathrm{SO} \mu \mathrm{R} / \mathrm{hr}$. The concrete was subsequently fretreleasod.

Demolition of the concrete vault commenced folkwing free-release. Ratiation measurements above the bole un the concrete floor indicated a level of about 20 
$\mu R / w r$, which was aboul four times above backeround. Howeves, the shielding effect of pauring an 8-inch-thick cencrete floor back fito the hole reduced the radiation level by a factor of eight, bringing the final radiation level below background.

The last radiological issue for this facility was the radioactively contaminated lead contalners. Since these containers were classified as a mixed waste, dispossal was nol an alternative for disposition; therefore, the containers were transfersed to a properly licensed facility for use as radiation shietding. Alout 2,000 pounds of lead were dispositioned in thls manner.

A thorough walk-over radiological survey with two handheld radiation delectors was performed ofter completion of all D\&D activities. The result was background radiation kevels of $5 \mu \mathrm{R} / \mathrm{hr}$, with no location being more than $1 \mu \mathrm{R} / \mathrm{u}$ above this level. The state regutatory agency subsequently terninated the license for this facility in Jure 1991.

\subsubsection{LLW Generation}

Ten trailer truckkasds containing 400 000 pounds (approximately 3,400 ft) of radioactive concrete were sent to the Barnwell LLW sile for disposal. In addition. 15,000 lt $^{3}$ of conerete was shipped to an industrial landfill for disposal. This "clean" concrete was surveyed in $90 \mathrm{ft}^{3}$ batches as part of the QA progran. Only one batch was rejected for repackaging. This batch contained a steel plate used to hold the vault doar roller, which contained ${ }^{\circ} \mathrm{Co}$, and was shielded during the fre release survey. The $15,000 \mathrm{ft}^{3}$ of concrete was calculated to contsin 1 total madionctivity of $15 \mathrm{mCC}$.

\subsubsection{Cost of D\&D}

The total effort of D\&D the cyclotron facility and restore it for reuse reguired approximately 5,100 personthours and $\$ 1.2$ million. Of this total, approxinately $\$ 390,000$ was for transportstion and disposit of radibactive waste.

\subsection{Interstate Nuclear Services Laundry Facility ${ }^{\prime}$}

This facility, located in Charleston, South Carolina, is a radiological laundry used to decontaminale clothing and other articles that have been radiologically contaninated at nuclear facilities. The facility was shut down in 1993 and deconnaminated and decommissioned during June to September of that year. This facility was slated for decorbutissioning because its primary client was ceasing operations and because upgrading of the water processing system was deemed unecanomical.

\subsubsection{Description of the Facllty}

A layout of this facility is provided in Figure 3.4. Key equipment in the facility includes lage comenercial wasthers and dryers 10 clean the clothing. Assoctaved with these systems are a water treatment system, filtration systems, steitling tanks, pumps, scretis, etc., to ensure that radiasctivity remaved from the clothing is contained and not released to the environmeal.

After cleaning, the clothing and associaned items are monitored on atlorntled special equipment with insinmentation designed to alarm if the levels of acceptable fixed contamination as established by the client are not met. After confirmation that the residual radioactivily criteria have been met, the clothing is sorled, folded, packaged, and shipped back to the clien! according to their specifications. These activities are conducied in the Production Room

\subsubsection{Summary of D\&D Actlities}

Because of the nature of activities performed in this facillity, low levels of radioactive contamination were sptead throughout the facility, including the mishinery and equipment, tanks, pits, filter housings, exterior wastier parts, pipes, overhead ceilings, salls, and so on.

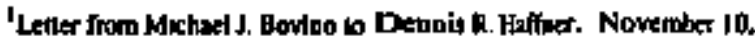
1994 hikrstace Nuckar Services, Springtield, Musachusens
} 
Figure 3.4 Layout af the radiotopteal laundry tacility

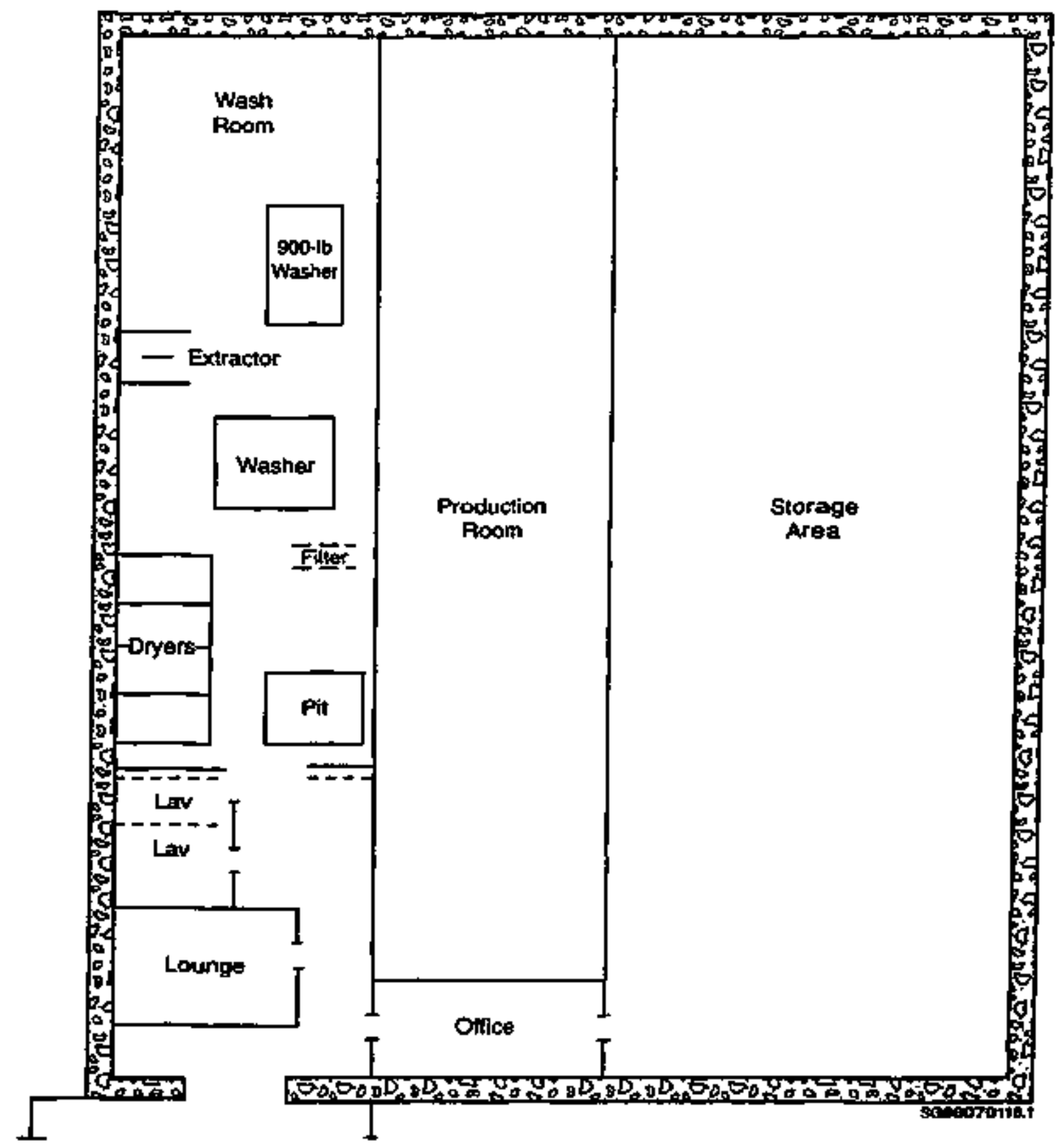


While doses from this residul contamination were not high, the entire facilty and associated ecpujpment required monitoring deting decommissioning. The following is a summary of the basic events that transpired during the decommissioning process:

- mobilization of technicians, equipment, elc. at the facilily beginning in early June 1993

- perfomence of presurveys and preparation of set-up areas, tinstrumentztios, and wark schedules

- dismantlement of equipment, tearing down walls, cutting lines, tuming oft gas, electricity, sewage, etc.

- packsping radioactive malerials and removing ceitings, lights, fans, air conditioning, and duct work

- removing vinyl flooring, ibsulation, offrce furniture, and fixtures

- cleaning pits, flushing lines, and inspecting surrounding sewage systems

- tracing old lines and removing as necessary

- having regolatory inspectoss perform their own tinspections and surveys for release of the facility.

A major activity during the decommissioning process was to section the dyers and washers into pleces to be decontaminated or tisposed as radioxetive waste. This sectioning was perfonned using a plasms arc torch becsuse of its quick colting rate that allowed handling of the sectioned material essentially inmediately offer the cut had been made. Smake generated by the plasma arc torch was treated using a hith efficiency particulate air (HEPA) filter system.

A high-pressure washer was used to spray down the entice area after the equipment had been renoved. This washer system delivered water a1 a pressure of about 2,000 psi mixed with detergent mix. It consisted of a high-pressure pumping system mounted on wheek and a length of highpressure hose with an extended wand and adjustable tip section.

When washing wth the high-pressure water system was complele and the areas dy, the floors, walls, elc. were monilorei. If detemmined to be clean of smearable contamination, they were then monikxed for fixed contamination. Artas determined to be contaminated with fixed contamination were sesblite. Four different types of scabblers wete used: a needle gun, a hand scabbler, a large floor scabbler. and jackhammers. The type of scabbler used for any particnlar situation depended on the extent and difficulty of removing the fixed contamination. A HEPA filusion systern was used to remove aiblonte radioactivity generaled from these operalions and sometimes temporary kents wete set up around the area being seabbled to contain the radiogativity.

\subsubsection{Cost of D\&D}

The total cost to D\&D this facility was approximitely $\$ 220,000$, with approxinutely $\$ 60,000$ attributed to disposal of tow-level radioactive waste. This cost does not include such itents as restoring the biriding for reuse. compensalion for terminating employses, taxes, lease, etc. Since the facility wos decomunissioned in-house, this cost also does not include health physics or engineering support steff, nor does it include purchese of most of the equipmeat used ip the DadD process.

\subsection{References}

1. S. M. Shoth October 1989. Technology, Safety and Costs of Decommissioning Reference Non-FuetCycle Nuclear Facilities. NUREGKR-1754. Addendum 1. U.S. Nuclear Regulscory Connission Report by Pacific North west Loboratory. Richland, Washington.

2. "Docket for Certifteation of Remedial Action for Release of King Avenue Building $3(K A-3)$ of the Battelte Columbus Laboralories Decommissioning Project." September 1995. Battelte, Columbus, Ohio.

3. Drzyzga, M. July 1991. Deromitsioning and Disposal Projert for Cyclotron Vasils Srructure. Hoftmann-Li Roche, Inc. Nuxley. New Jersey.

4. Moore, J. D. M.E. Remiley, and V. A. Swansen. Fetmuary 1988. Supplemental Radialogical Survey. Medi-Physics Cyclorron Cell. Rockwell Intemational Corporation, Cenoga Park, Califormia. 


\section{Review of Emerging Decontamination Technologies}

This chapter discusses three new processes; $\mathrm{a} \mathrm{CO}_{2}$ pellet decontamination technology used for non-destruelive surface decontamination, a moilen thetal balh technology for dissolving waste compounds inlo their constituent eiements, and a supersonic gas-liquid surface cleaning technalogy. Although none of these technologies contributed to the development of the cost methodologies used in this study, a discussion of them is in order because they are representalive of important new developisents that may soon join the collection of siandard decominissioning techniques that will lead to significant decotrmissiaring cost savings in the future.

In general, the three kechnologies cited are relatively new with limited conmercial deployment. Their cost-effective use depends leavily on the wltimate destiny of the contaminaled components. If recycle of the compenents (ot the base material) is likely, the added cosl of these new techerologies may be justified when salvage value is considered. If the composent is unlikely to be reused, decontaminabion efforts should be limiled to that necessary for disposal as LWW.

\section{1 $\mathrm{CO}_{2}$ Pellet Decontamination Technology}

The carbon dioxide $\left(\mathrm{CO}_{2}\right)$ pellet decontanination process is a unique dry process that uses thy ice as the exclusive decontaminacion medium, and does reot use any lazardous cherricals, water, solid grit or aggregate materials. This process generates no secerstary wasles and is a nondestructive surface cleaner. A forerenner in the development of this promising new decontamination process is Nor-Destruetive Cleaning, Inc. (NDC) based in Walpole, Masstacbusetrs.

The NDC patennod process/facility uses small, solid carbon dioxide particles propelled by dry compressed air. The $\mathrm{CO}_{2}$ particles shatter upon impset with the surface of the maierial to be cleaned and flash into dy $\mathrm{CO}_{2}$ gas. This flashing into a gos results is a raptd volume expansion of approximitely ten to ons. Cleaning is accomplisted by the rapidly expanding $\mathrm{CO}_{2}$ gas flashing into the surface of the material to be cleaned (which is porous at the microscopic leve]) and flushing the foreign materials out. The microscopic particies of foreign material are captured on high efficiency particulate air (HEPA) fillers. Larger-sized fragments are lifted off the surface by the nashing $\mathrm{CO}_{2}$ gas and are temoved using HEPA-fillered yacuum cleaners. The only waste product from the NDC facility is the diy HEPA filters that are easily disposed of as dry active waste. $\mathrm{CO}_{2}$ levels have been demonstrated to remain below OSHA limits, and a $\mathrm{CO}_{2}$ monitor verifies the levels during operation. Examples of ilems successfully decontaninated include: hand tools, power toois, purtips, tanks, glass, pipes, conputer components and citcuitry, respirators, manipulators, and lead shielding.

The NDC mobile CO, decontamination unit is a standalone, transportable, steel enclosutt. The unit has a single. disect 480-vols power connection. No specisl mountings are required, and the onit can be piaced on any firm flat surface, such as a paved lot or crushed tone. The unit is designed for cleaning items ranging in size from small hand tools to items up to 20 feet lang, with no weight limit.

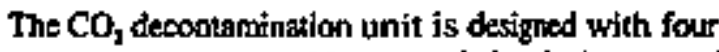
separate rooms: a frachinery and electicat room, a large deconlaminalion room, a decontamination cell room, and a count room where citeaned items are surveyed after cleaning. All electrical imtersonnections art managed by a central power cable that is connected to a power control and distribution panel located within the mobile unil. The unit has been designed with a complete HVAC system. allowing operation in any environment.

The $\mathrm{CO}_{2}$ dexontarnination room is completely lined with strinless steel, and includes a large entry door and an internal hoist that cim handle up to two tons. 'The floor loading capacity is unlimited. The decan room ventitation system inclites two pre-fitleers and a HEPA filter system. The deconlamination room is pre-piped for the use of supplied breathing at for worker saiety. A special rolling lift table equipped with an air-driven vise to hold iterns for cleaning has also been designed for use in the unit. 


\subsection{Molten Metal Technology}

An aturacirve feature of the new molten metal technology process, developed by Molten Metal Technology, lnc., is the abilily to process both hazardous and radioaclive waste materials (commonly referred to as mixed wastes) simultaneously. The new process is also feferred as the Quantum-CEP ${ }^{\mathrm{TM}}$ technology.

Quantum-CEP ${ }^{\text {nd }}$ is an adaptation of the CEP (Calalytic Ex(raction Process) lechnology. Quanturn-CEP allows bolh destruction of hazardous components and controlled partitioning of radionuclides. This leads of decontamination and tecyeling of a large portion of the waste components to commerctal products as well as volume reduction and concentration of radıonuelıdes for final dıspossi.

A Quantum-CEP demonstration system has recently begun processing radioactively contamnated ion exchange resins, depleied uranium bexafluoxide (IJF) from the U.S.

Enrichment Corporation (LSEC), and mixed hazardous and radioactive waste from the Deparunent of Energy and conumercial customers.

The new technique uses a molien metal bath to dissolve waste compounds into their constituent eitements. More precisely, the catalytic and solvent properties of molten melal dissolve the wastes' molecular bonds, which allows the company to separale reusable chemicals for rocycling.

The process begins in a sealed tank that contains a molten metal bath, usually comprised of jon that is heated to around $1650^{\circ} \mathrm{C}$. The compositon of the bath may be attered, however, depending on whal metal producis the generator hopes to recover.

Once the bath is ready. wastes are injected into the tank by way of special pipes. Bits of wastes-powders, for example-are injected imlo the botton of the tank though small pipes called "tutyeres"; bugger chunks of solid waste are deposited on top of the metal bath by way of larger tubes called "lances."

Upon entering the bath, the molectular bonds of the contaminants begin to break down as a result of specific separation reagents added to the molten metal bath. The waste then begins to separate into three distinet lsyers: gas, which rises to the top of the tank; metals, which remain in
The metal bath; and ceramec, which farns on top of the metal layer. Proponents of the technology say that melting waste in solution is preferable to applying flame direetly to it as a means of recovering the elements, primarily becsuse the chemical reaction is mere controllable.

The process also separates the radionucludes from tronradioactive elements, and the radioartive components of the wasle become trapped either in the ceramic or melal layers. The process allows for the recovery of the mon-radionactive elements for reuse of recycle.

Processing the wasle using the technology ranges from $\$ 150$ per ton for hazardous waste to upwards of $\$ 2,000$ per ton for LLW or mixed waste.

\subsection{Supersonic Gas-Liquid Cleaning Technology}

The supersonic gas.] iqutd cleaning technology is a relatively new cleaning technology, developed by the U.S. National Aeronaulics and Space Admunistration (NASA) prirkarily as a replacement for solvemt flush methods using Freon 113 (CFC L 13). Applications for radioactive decontamntiolion have not yel been developed hat show promise because of the sıgnificantity reduced ligusd volumes used in the cleaning operation.

The system works by mixing atr and waler from separate pressurized tanks and ejecting this mixture at supersonic speeds from a series of nozzles at the ent of a hand-held wand. At these speeds, the water droptets have the kinetic energy lo forcibly remove the conlasurant material.

The system consists of a supersonic converging-diverging nozzle, a liquid arifice, a regulated hugh-pressure gas source, a high-pressure liquid tank, and miscellaneous hoses, fitings, valves, and gauges. Liguoid is injected into the gas Jow stream just upstream of the convergingdiverging section of the nozzle. The liquid-gas mixture then enters the converging-diverging nowele where it is accelerated to supersonic speeds. The supersonic gasIrouid stream exils the nozzle where it is durected onlo the component to be decontaminated. The velocity imparted to the liquid by the gas now gives the luquid sufficient momenlum at impacl to remove contammants from the surface while sirnultaneously dissolyng or emulsifying the 
contaminants into the liguid. The flow parameters for the gas-liquid nozale cen be set so that virually any gas and liquid may be used for the desized flow and nuxing ratio. In adcition, the size and number of sozzles are adjustable. making it posstible ta create various sizes of nozzles configirations.

One of the many advantages of the supersonic fas-liquid cleaning syslem over other pressurized cleaning methods is that it does not abrade the surface of the hardware being cleaned. Hi requires much lower levels of pressure-$320 \mathrm{psig}$ for water and 300 psig for gas (air or nitrogen). The relatively low volume of water required, approximately 30 milliliters per minure, means much less secondary contaminated waste. These system design parameters result in a clesaing rate of one square foot in Itree minutes.

Separale paxent license apreements have been developed between NASA and two independent cormpanies for comnercial applications. The companies are Prectsion Fabricating and Cleaning Co. of Cocos, Florida, and Va-tren Systems, Inc., of Chula Vista Califormia. The agreement is a means for NASA to ellectively uransfer technology initially developed for the space program to companies that may derive innovative commercial uses from il. 


\section{Decommissioning of Facility Components}

Several facility components are common to the geference maxclear material processing and ase haboratories described in Section 7 of NUREG/CR-1754, "1) These components include fume boords, glove boxes, baboratory workbenches, hot cells, sinks and drains, duct work, fitters, and building sarfaces such as floors, wail and ceitings. Sone of these concponents experience significant radioactive contamingtion ducing the opentional phase of a labontory. Release of a laboratory for unrestricted use and termination of the radioactive material license requires that contaminated components either be 1) deconteminated to unrestricled relesse levels or 2) packaged and shipped to an authorized disposal site. Slace the first alternative is considered to be too costly and time-consuning, only the second alterative is analyzed in this study.

Rerooval of contamination that has penetrated to the intetior of sinuctural walls or benesth the primtary surfacing on floors is not incloded in these generic analyses becuuse the effort mod cost of retroval in these instinces is very situation-specifis.
Facility components common to the reference processing and use laboratories and radioisotopes postulated to contaninate those components ase shows in Table S.l. Information in the table is based on the facility descriptions in Section 7 of NUREG/CR-1754,

The technicpl approach used to estimate requirements, costs, and occupational safety for decommixsioning facility corqponepts is described in Section 5.1. Decormmissioning analyses for individual tomponenis art presented in Section 52.

Cost and safety information for decommissioning the reference processing and use laboratories is presented in Chapter 6, based oc the cost and occupational radiation dose estimates for cocommissioning individual facility components developed in this chapter. This unitcoroponent approach to the analysis of decommissianing is designed to provide data and examples to assist users of thits study in estirmaling the requirements, costs, and safety of deconnusssioning other non-fuel-eyele nuclear facilities.

Table 5.1 Contaminated faclity components common to the reference processing and use laborntories

\begin{tabular}{|c|c|c|c|c|c|c|}
\hline \multirow[b]{2}{*}{ Facillity componeat } & \multicolumn{6}{|c|}{ Liboratory } \\
\hline & 'H & ${ }^{4} \mathrm{C}$ & InI & ${ }^{m^{\prime}} \mathrm{Cs}$ & ${ }^{21}$ Am & User \\
\hline Fune bood & $x^{\prime(4)}$ & $x$ & $x$ & $x$ & $x$ & $x$ \\
\hline Glowe bex & $x$ & $x$ & $x$ & & $\mathbf{x}$ & $\pi$ \\
\hline Srnoll hat cell & & & & $x$ & & \\
\hline Leboratory workemch & $x$ & $\mathbf{x}$ & $\mathbf{x}$ & $\mathbf{x}$ & $\mathbf{x}$ & $\mathbf{x}$ \\
\hline Ventilation ductwork & $x$ & $x$ & $\pi$ & $x$ & $x$ & $\mathbf{x}$ \\
\hline Cabinet & $\mathbf{x}$ & $x$ & $\mathbf{x}$ & & $\mathbf{x}$ & \\
\hline Refingerators/freeder & $\mathbf{x}$ & $x$ & $\mathbf{x}$ & & & $\mathbf{x}$ \\
\hline Fijters & $x$ & $x$ & $\mathbf{x}$ & $x$ & $\mathbf{x}$ & $\mathbf{x}$ \\
\hline Sinks and drains & & $\pi$ & $x$ & $x$ & & $\mathbf{x}$ \\
\hline Butilding surfaces & $x$ & $\mathbf{x}$ & $\mathbf{x}$ & $x$ & $x$ & $x$ \\
\hline
\end{tabular}

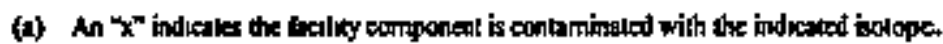




\subsection{Technical Approach}

The technical appraach and some kcy bases used to definc requirements and estimate cost and salety of decommissioneng facility components are discussed w thes section.

This study analyzes two decorruissioneng options:

(1) Disassembly and disposal of contamurated facilıty components using sectroning, compaction, and supercompaction.

(2) Disussembly and disposal of condaminated facility corrponents using sectioning, compaction, and a combunation of conpaction and incincration

Both options require that the corrponents be cut up, packaged in 208-titer drums and corrpacted on-5ite before being sent to a facilify for supercompackson and/or incineration.

The authorized disposal sile is assumed to be a shallowland burial ground located $800 \mathrm{~km}$ Grom the laboratory being decommissioned and from the centrally located supercomrqactor faciltty. The supereompactor/mineralor facility is assumed to be located $350 \mathrm{~km}$ from the laborstory being decommissuoned. Transportation of radioactive waste to the supercompaclor facility and disposal site is assumed to be by exclusive-use trick. Waste is transported in accortance wrth applicable fedteral, state, and local regulations.

\section{S.1.1 Cost Estimates}

Estimbtes of costs for bott the decombarrination oplion and the disassembly and disposal option are riade for each facily compooent listed in Table 5.1. Costs melude manpower, equipment and supplies, and waste management cosis. Same key bases and assumptions for estuming costs are given in Appendix A. All casts are expressed m Jamuary 1998 dollars.

Decontamination of facility components is assumed to be performed by cuployees of the ownetopernion of the facility. Manpower cosis are determmed by milliplying the persont-days required to decommission a component by the costs per map-day shown is Appendix D. To delemine the total tire required to decommission a component, an esturnate is made of the time required for efficient perfommance of the work by a postulated work erew. This twe estimate is then increased by $50 \%$ to provide for preparatoon and set-up tırse, resi periods, etc. (ancillary time).

The tirne Jequired to complete a parteular deçommissioning task is estimated on the basis of a work crew consisting of a foreman and two technicians. The technjeians are assumed to have had some experience working with radiochemicals, to be trained in radiological safety proce. dures, and to be capable of operating rodiation survey equipment as welt as the tools and equipment used to contarunate the faciluty. Craftsmen such as electricians, pipefitters, and sheet metal workers are assumed to be added to a work crew as the situration requires. Rodiation survey equipment and equpmont for the analysis of wipe samples ere assumed to be teadily avaleble and not chargeable to decommssioning because such equpment is also used duning the operation of the facility.

Wasle mankigement costs include supersompaction or incineration costs, container costs, trarsportation costs, and waste disposal charges. Transportalion charges ate based on the fraction of a truckload required to transport the decommissiontng wastes from an indridual facility com ponent. It is assumed that one truckload consists of one hundred-twenty 208-liter steel drums or eighty 208-liter drums of supercompacted waste. Because supercompac. tion, incineration, transportation, and waste disposal operations are contracked activities, minpower costs for these operations are included in the total costs of these ttcms.

\subsubsection{Occupational Radiation Dose Estimates}

Estimates of occupational radiation doses are made for wach facility component listed in Table S.l. The estimated worker dose rates that form the bases foe occupational dose calculatians are given is Section 8 of NUREG/CR-1754."

\subsection{Decommissioning Analyses}

Resuls of analyses of tìne, manpower requìements, total costs, and occupational radiation doses for decommissionIng facility components are presented is this section. The analyses ate performed for the various facility components for the supereompaction ard supercompaclion/incineration options. Total costs include the costs of manpower. 
equipment and supplies, ead waste maragement (e.g, the packaging, tansportation, and disposal of radioactive waste).

Detailed cost estimates for decomunissioning lacility components are presented in Ajpendix C. Manpower trimates for al conponents in all the reference taboratories are shown in Tables D.I.a through D.6.b of Appendix D. Appondix A sururatizes the kcy bases and assumptions used in estimatimg the requirements and costs of decormissioning.

Occupational rediatien doses are estimated by molipplyùng the dose rates approptiate to each contominant (Reference 1) by the person-days required ta decommission the copponent. It is nessimed that components coptaminated with ${ }^{241}$ AJn can be disposed of by shallow-tand burial. This rey noc be the case if the residual contaningtion level ts greater than 100 pCVgran of waste, equivakent to an average surface contamintation on the intetion surfaces of a conponent of about $4 \times 10^{7} \mathrm{~d} / \mathrm{m} / 100 \mathrm{~cm}^{2}$. If the avarage sarface contamination exceeds this value, it may be necessary to partiully decontuminate the component or to provide for interin otorage of the contaminated hood, since facilities for the petmeneat disposal of transuranic wastes Ere not yet available.

The mild surfice decontamination of the snatl ho cells in the " ${ }^{17} \mathrm{C}$ s lab and the jead vault in the user facility
(Appendix D) witl result in radioactive mixed waste, This tnixed waste product will therefore be subjext to both the Resource Conservation and Recovery Act (RCRA) regulations and NRC regulations on final disposal. Since no existing disposal siles have as yet been approved for disposal of mixed waste, other, possibly more costly. decontamination melhods may need 10 he used. However. for this andysis, a mixed waste disposal site is assumed to be avaibable for the same cost as a LLW disposal site.

\subsubsection{Fume Hoods}

Estimated time and menpower requirements, total costs, and occupational radiation doses for decommissioning a fume hood by the packaging and disposal option 1) with supercoupaction only and 2) with both supeccompaction and treineration ate shown in Table S.2. A typical fume hood decamersssioned in this study had exteriar dimensions of $1.5 \mathrm{~m}$ wide by $0.9 \mathrm{mdecp}$ by $2.1 \mathrm{mbigh}$. A work crew consisting of a foreman and two technicians is assimed to perform the wart. Postulated procedures used to DECON the furme hoods are discussed in Appendix D. The average time to DECON a furne hood is 1,5 days. The average manpowet reputrement is 5.3 person-days. Costs average

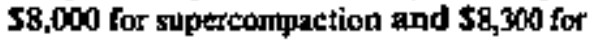
superconpaction with incineration.

Occupational rediation doses range from $8 \times 10^{-6}$ personrem $101 \times 10^{-1}$ person-rem, depending an the type of contmmination.

Table 5.2 Summary of estimated manpower requirements, oceupitlonal radiation dose, and total costs for DECON af a fune hood

\begin{tabular}{|c|c|c|c|c|c|c|}
\hline & \multicolumn{6}{|c|}{ Leboratory } \\
\hline & ${ }^{2} \mathbf{H}$ & ${ }^{14} \mathrm{C}$ & $1 \pm \mathbf{I}$ & $\mathrm{M}_{\mathrm{c}}$ & H1ANI & Uter lob \\
\hline Time (days) & 1.5 & 1.4 & 1.4 & 1.6 & 1.5 & 1.5 \\
\hline Menpower (pers-days) & 5.3 & 53 & 5.2 & 5.6 & 5.4 & 5.3 \\
\hline Radiation dase (person-nem) & $8 \times 10^{3}$ & $8 \times 10^{6}$ & $3 \times 10^{-3}$ & $1 \times 10^{-1}$ & $5 \times 10^{-2}$ & $8 \times 10^{9}$ \\
\hline Costs $(\$ 600)^{(0)}$ & $\begin{array}{l}7.5 \\
7.9\end{array}$ & $\begin{array}{l}8.0 \\
8.3\end{array}$ & $\begin{array}{l}7.5 \\
7.7 \\
\end{array}$ & $\begin{array}{l}9.1 \\
9.4 \\
\end{array}$ & $\begin{array}{l}8.0 \\
8.4\end{array}$ & $\begin{array}{l}7,6 \\
7.9 \\
\end{array}$ \\
\hline
\end{tabular}

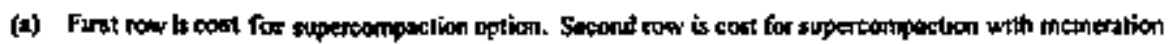




\subsubsection{Glove Bores}

Estimated tome and manpower requirements, total costs, and occupational radiation doses for deconmissioning a glove box by the two options are shown in Table 5.3. A typical glove box decommissioned in this study had exterior dumensions of $1.5 \mathrm{~m}$ wide by $0.9 \mathrm{~m}$ deep by $2.1 \mathrm{~m}$ high. A work crew consisting of a forman and two tech. nicians is assumed to perform the work. Posnlated procedures used to DECON the glove toxes are discussed in Appendix $D$. The average time $10 \mathrm{DECON}$ a glove box is 0.6 days. The average marpowes requiremem is 2.2 person-days. Costs average $\mathbf{3 4 , 2 0 0}$ for super. compaction and $\$ 4,400$ for supereompaction with incineration. Occupalional radiation doses range from $2 \times 10^{-7}$ person-rem to 2 person-rem, depending on the type of contantination.

\subsubsection{Small Hot Cell}

The only reference labazatory that contains hot cells is the laboratory for the manufacture of ${ }^{13 t} \mathrm{Cs}$ sealed sources described in Section 7.1.4 of NUREG/CR-1754," It is estimeted that 1.9 days and 7.7 person-days will be required to DECON one of these hot cells. The occupational radiation dose is estimated to be about 2 person-rem. For the sujperconpaction option, the cost is estimated to be
$\$ 26,500$; for the supercongaction with ancineration option the cost is estimated at $\$ 26,800$. A work crew corsisting of a foreman and two technicians is assumed to pertorm the work. Postulated procedures used w DECON a hot cell are discossed in Appendix D.

\subsubsection{Laboratory Workbenches}

Estımated time and manpower requiremknts, total costs. and occupattonal radiation úoses for decommisșoning a workbench by the two options are shown in Table 5.4 . Workbenches decommissioned in this sudy varied from facility to facility (Appendix C), bul a "typical" bench measured $0.9 \mathrm{~m}$ high by $0.75 \mathrm{~m}$ wide by $4.6 \mathrm{~m}$ long. $A$ work crew consisting of a forertin and wo technieiens is assumed to perfom the decommissfontng work. Postulated procedures used to DECON the workbenches are discussed in Appendix $D$. The average time to DECON a bench is t. 7 days. The averge mampower requirement is 6.1 person-days. Costs averaged $\$ 8,800$ for supercompaction ard $\$ 10,200$ for supereompaction with incúierabon. Occupational radiation doses range from $2 \times$ $10^{\prime}$ person-rent to $4 \times 10^{3}$ person-rem, depending on the type of costumunation. Durting decontamination of the workbench, most of the radiation dose to workers is from radioactive contarnination on the floor and walls of the room in which the workbench is localed.

Toble 5.3 Sunmary of estimated manpower requireniends, occupational radiotion dose, and tolal costs tor DECON of a glave box

\begin{tabular}{|c|c|c|c|c|c|c|}
\hline & \multicolumn{6}{|c|}{ Laboratary } \\
\hline & 'H & ${ }^{10} \mathrm{C}$ & 'H & ${ }^{21} \mathrm{Cs}$ & ${ }^{24} \mathrm{Am}$ & Ușer lab \\
\hline Tirne (days) & 0.4 & 0.4 & 0.4 & - & [ .3 & 0.5 \\
\hline Maspower (pers-fays) & 1.7 & 1.6 & 1.6 & - & 4.4 & 1.9 \\
\hline Radiation dase (person-tem) & $7 \times 10^{-4}$ & $2 \times 10^{7}$ & $4 \times 10^{-3}$ & - & $2 \times 10^{\circ}$ & $7 \times 10^{-4}$ \\
\hline Costs $(5000)^{\{(2)}$ & $\begin{array}{l}3.3 \\
3.5\end{array}$ & $\begin{array}{l}3.5 \\
36\end{array}$ & $\begin{array}{l}4.0 \\
4.0\end{array}$ & - & $\begin{array}{l}6.7 \\
7.0\end{array}$ & $\begin{array}{l}3.5 \\
3.7\end{array}$ \\
\hline
\end{tabular}

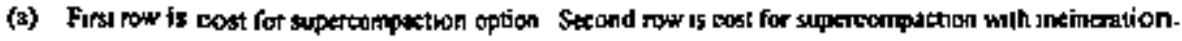


Table 5.4 Summary of estimated manpower requirements, occupafional radjation dose, and total costs for DECON of a warkbench

\begin{tabular}{|c|c|c|c|c|c|c|c|}
\hline & \multicolumn{7}{|c|}{ Leboralory. } \\
\hline & ${ }^{3} \mathbf{H}$ & - & ${ }^{n C}$ & 134 & $\mathrm{M}_{\mathrm{Cs}}$ & NAm & User lab \\
\hline Time (days) & 0.6 & & 1.8 & 2.0 & 1.9 & 2.4 & 1.7 \\
\hline Manpower (pers-days) & 2.2 & & 6.1 & 6.7 & 6.7 & 8.7 & 6.0 \\
\hline Radiation dose (person-tem) & $2 \times 10^{-7}$ & & $6 \times 10^{-5}$ & $4 \times 10^{-3}$ & $3 \times 10^{5}$ & $4 \times 10^{-1}$ & $6 \times 10^{-7}$ \\
\hline Costs $(\$ \infty 00)^{(2)}$ & $\begin{array}{l}2.6 \\
2.7 \\
\end{array}$ & . & $\begin{array}{c}9.9 \\
\mathbf{1 2 . 4}\end{array}$ & $\begin{array}{l}8.7 \\
9.0\end{array}$ & $\begin{array}{r}11.8 \\
14.4 \\
\end{array}$ & $\begin{array}{l}10.6 \\
10.8 \\
\end{array}$ & $\begin{array}{r}9.3 \\
11.9 \\
\end{array}$ \\
\hline
\end{tabular}

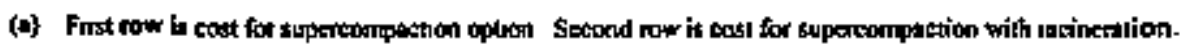

\subsubsection{Ventilation Ductwork}

Estimated time and manpotwer requiremnents, total costs, and occoupulional ndiation doses fox decommissfoning ductwork by the two options are shown in Table 5.5. The estinnies are based on the pactaging and disposal of $20 \mathrm{~m}$ of $0.20 \mathrm{~m}$-diameter sbeet metal ductwodk plus $20 \mathrm{~m}$ of 025 -m by 0.60-m retctangular sbeel melal ductwork. $A$ work crew consisting of a foreman and two technicieris is assumed to perform the work. Postulated proceduries used to DECON the ductwork are disctussed in Appendix D.
The average time to DECON ductwork is 3.6 days. The average jonpower requirement is 13 persou-days. Cost averaged $\$ 14,900$ for supercompaction and $\$ 15,300$ for supareompaction with incincration. Oxcupational radiation doses ranged from $2 \times 10^{-6}$ persont-lant to $1 \times 10^{-2}$ persotr. rem, depending on the type of eonmmination. The highest worker exposures are associated with the packagine of ${ }^{24}$ Am-contaminated duchwork. These radiation exposwres can be jeduced one or two orders of magnitude if workers use protectire iespintory equipment.

Table 5 s Sumbary of estimuted moqpower requirenoents, occupational radiation dase, and tofol costs for DXCON of ventilation dpels

\begin{tabular}{|c|c|c|c|c|c|c|}
\hline & - & 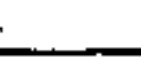 & Leb & tory & & \\
\hline & 패 & ${ }^{14} \mathrm{C}$ & $\mathbf{m i}$ & ${ }^{\prime \prime C} C_{5}$ & ${ }^{21} \mathrm{Am}$ & Uner lab \\
\hline Tipne (days) & 3.5 & 3.3 & 3.6 & 3.7 & 3.6 & 3.8 \\
\hline Manpower (pers-đays) & 12.2 & 11.7 & 127 & 13.1 & 12.7 & 13.2 \\
\hline Rediation dose (person-rexn) & $2 \times 10^{4}$ & $2 \times 10^{4}$ & $6 \times 10^{3}$ & $3 \times 10^{3}$ & $1 \times 10^{-2}$ & $2 \times 10^{6}$ \\
\hline Costs $(5000)^{1-1}$ & $\begin{array}{l}13.1 \\
13.5 \\
\end{array}$ & $\begin{array}{l}t 3.6 \\
14.0 \\
\end{array}$ & $\begin{array}{l}15.9 \\
16.3 \\
\end{array}$ & $\begin{array}{l}172 \\
17.6 \\
\end{array}$ & $\begin{array}{l}15.1 \\
15.5 \\
\end{array}$ & $\begin{array}{r}14.2 \\
14.6 \\
\end{array}$ \\
\hline
\end{tabular}

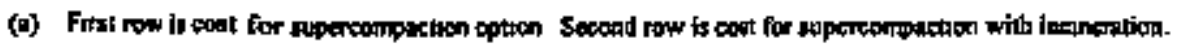




\subsubsection{Cabinets}

Eslinated line and manpower tequirements, 10ta] cosis, and occupational radiation doses for decommissioning a storage cabinet by the two options are shown in Table 5.6. A work crew consisung of a foreman and two lechnictens is assurned to perform the work Postulated precedures used to DECON the caburets are discussed un Appendix $D$. The average time to DECON a cabtnet is 0.4 days. The average cuanpower requtrement is 1.6 person days. Costs average $\$ 2,400$ for supereompaction and $\$ 2,800$ for supercompaclion with uncineralson Dccupational radiation doses ranged from $7 \times 10^{.7}$ person-rem to $3 \times 10^{3}$ personsem, depending on the type of contirmation.

\subsubsection{Freezers and Refrigerators}

The freczers and refingerators in the ' $\mathrm{H}$, "C, and ${ }^{123} \mathrm{~T}$ taboratories are all assumed to be upright units with dirnenstions of $0.6 \mathrm{~m} \times 0.6 \mathrm{~m} \times 1.5 \mathrm{~m}$. The estimated time and manpower jequirements, 10ta] costs, and occupational rediation doses for decorrutissioning a freezer or sefrigentor by the two options are shown in Table 5.?. A work crew consisting of a foremen and two technicians is assumed to perform the work. Postulated procectures used to DECON these appliances are discussed in Appendix D. The average tine to DECON a freezer of refingerator is
0.6 days. The average manpower requirement is 2.1 person days. Costs average $\$ 6,000$ for supercompation and 56,400 for supereonpaction with disineration. Occupstional radiation doses range from $1 \times 10^{6}$ person-sem $102 \times$ $10^{5}$ person-rem, iepending on the bye of contamination.

\subsubsection{Filters}

Alt the reference laboratones contain HEPA and roughing filters on the ventilaton exhaust systerrs conrtected to the fume hoods and glowe boxes. The ${ }^{\mathrm{kt}} \mathrm{C} .5$ laboratory contains one HEPA and roughing filter on exch of the ait outiets from its two bot cells. Each HEPA filter is $0.2 \mathrm{~m}$ in diatreiter and $0.2 \mathrm{~m}$ high; a roughung filter $150.2 \mathrm{~m}$ in

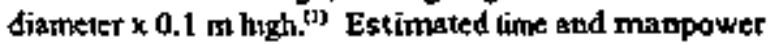
requirements, lotal costs, and occupational radiation toses for decommissioning a HEPA or roughing filter by the two options are shown in Table 5.8. A work crew consisting of a foreman and two lechnicians is assumed to perform the work. Postulaied procturts used to DECON the fitters are discussed in $A$ ppendix $D$. The average time to $D E C O N$ a filler is 0.03 days. The average matpower requirement is 0.1 person days. Costs average $\$ 170$ for supercompaction and $\$ 2 t 0$ far supercompaction with uncueration, Occupational radiation doses ranged from $5 \times 10^{-5}$ person+rem to $2 \times 10^{4}$ person-rem, depending on the type of contamination.

Table 5,6 Sumusary of estimatet manpower requlrements, occapallonal radiatlon dose, and total costs for DECON of a storage cabinet

\begin{tabular}{|c|c|c|c|c|c|c|}
\hline & \multicolumn{6}{|c|}{ Labortoty } \\
\hline & ${ }^{\mathbf{3}} \mathbf{H}$ & ${ }^{14} \mathrm{C}$ & ${ }^{115}$ & ${ }^{\mathrm{C}} \mathrm{C}_{5}$ & ${ }^{141} \mathrm{Am}$ & User lab \\
\hline Tìme (days) & 0.5 & 0.5 & 0.5 & - & 0.5 & - \\
\hline Manpows (pers-days) & 1.7 & 14 & 1.8 & - & t.6 & - \\
\hline Radiatun dose (person1-rent) & $2 \times 10^{6}$ & $7 \times 10^{7}$ & $2 \times 10^{-5}$ & - & $3 \times 10^{-1}$ & - \\
\hline Costs $(\$ 000)^{(0)}$ & $\begin{array}{l}2,4 \\
3,0\end{array}$ & $\begin{array}{l}24 \\
3.0\end{array}$ & $\begin{array}{l}2.3 \\
2.3\end{array}$ & $\ddot{-}$ & $\begin{array}{l}2.4 \\
2.9\end{array}$ & $=$ \\
\hline
\end{tabular}

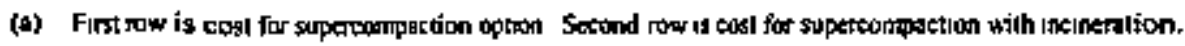


Table 5.7 Summary of estitmated manpower requirements, eccupntionat radistion dose, and totol costs for DECON of a freezer or refrigerator

\begin{tabular}{|c|c|c|c|c|c|c|}
\hline & \multicolumn{6}{|c|}{ Laboratory } \\
\hline & $\mathbf{H}$ & ${ }^{4} \mathrm{C}$ & $3_{1}$ & ${ }^{\mathrm{u}} \mathrm{Cs}$ & ${ }^{241} \mathrm{Am}$ & User lab \\
\hline Tine (days) & 0.6 & 0.6 & 0.6 & - & - & 0.6 \\
\hline Maspower (pers-days) & 2.1 & 2.1 & 2.1 & 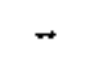 & - & 2.1 \\
\hline Radiation dose (person-tem) & $2 \times 10^{4}$ & $1 \times 10^{-6}$ & $2 \times 10^{5}$ & - & $=$ & $2 \times 10^{4}$ \\
\hline Costs $(\mathbf{S} \mathrm{OOO})^{(4)}$ & $\begin{array}{l}5.9 \\
6.2 \\
\end{array}$ & $\begin{array}{l}6.0 \\
6.3 \\
\end{array}$ & $\begin{array}{l}6.3 \\
6.7 \\
\end{array}$ & - & - & $\begin{array}{r}5.9 \\
6.2 \\
\end{array}$ \\
\hline
\end{tabular}

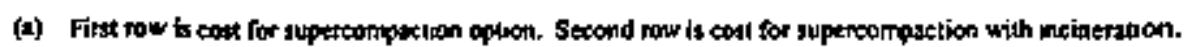

Table 5.8 Summary of estimated manpower requirements, occupational radiatlon dose, and lotsl costs for DECON of a HEPA or raughing fitter

\begin{tabular}{|c|c|c|c|c|c|c|}
\hline & \multicolumn{6}{|c|}{ Laboralory } \\
\hline & 'H & ${ }^{10} \mathrm{C}$ & ${ }^{129} \mathrm{I}$ & ${ }^{m} \mathrm{C}$ & ${ }^{241} \mathrm{Am}$ & Uster lab \\
\hline Time (days) & 0.03 & 0.03 & 0.03 & 0.03 & 0.03 & 0.03 \\
\hline Manpower (pers-days) & 0.1 & 0.1 & 0.1 & 0.1 & 0.1 & 0.1 \\
\hline Radistion đose (person-rem) & $1 \times 10^{7}$ & $5 \times 10^{*}$ & $1 \times 10^{4}$ & $2 \times 10^{-6}$ & $2 \times 10^{-4}$ & $1 \times 10^{-7}$ \\
\hline $\operatorname{Costs}(5000)^{(t)}$ & $\begin{array}{l}0.14 \\
0.17 \\
\end{array}$ & $\begin{array}{l}0.15 \\
0.18\end{array}$ & $\begin{array}{l}0.20 \\
0.25 \\
\end{array}$ & $\begin{array}{l}0.21 \\
0.26\end{array}$ & $\begin{array}{l}0.18 \\
0.22 \\
\end{array}$ & $\begin{array}{l}0.15 \\
0.18 \\
\end{array}$ \\
\hline
\end{tabular}

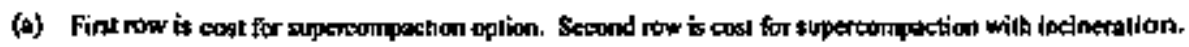

\subsubsection{Sinks and Drains}

Sinks are located in the referemce laboratories for the proparetion of "C- or ${ }^{12}$-labeled comipounds and tin the taboratory for the manufacture of ${ }^{17} \mathrm{Cs}$ sested sources. The sinks are used for personal ckenliness and for washing of tinsing non-contaninated glassware of glassware pre. viously decontrominaled. Contantrated tiquits are not purposely discharged to the sanitary sewer via these sinks. Hence, the sinks are anticipated to have low levels of rafinactive contamination.
Estirngled time and maxpower requtements, total costs, and oceupational ndiation doses for decommenissioning a sink and ossociated drain piping by het two options aye shown in Table 5.9. The reference sirk and drain deconmissiooed in this study bad a drain line with a diameter of $0.12 \mathrm{~m}$ and length of $10 \mathrm{~m}$. A work crew consisting of a foreman and two tectricians is assumed to perform the work. A pipefitter is temporarily added io the wark crew to disconnect the sink and cut the pipe. Postulated procedures used to DECON the cabinets are disctsesed in Appentix D. 
Table 5,9 Summary of estima1ed manpower requirements, occupational radtation dose, and total costs for DECON of a sink and deain

\begin{tabular}{|c|c|c|c|c|c|c|}
\hline & \multicolumn{6}{|c|}{ Laboratory } \\
\hline & ${ }^{3} \mathrm{H}$ & ${ }^{\mathrm{N}} \mathrm{C}$ & $m_{I}$ & ${ }^{\mathrm{m}} \mathrm{Cs}$ & ${ }^{141} \mathrm{Am}$ & User 19b \\
\hline Trune (days) & -. & 0,2 & 0.2 & 0.3 & -- & 0.3 \\
\hline Manpower (pers-days) & - & 0.9 & 0.9 & 1.0 & $m$ & 1.0 \\
\hline Radiation dose (person-rem) & - & $9 \times 10^{-4}$ & $1 \times 10^{-\infty}$ & $1 \times 10^{5}$ & - & $9 \times 10^{-6}$ \\
\hline $\operatorname{Cos} 15(\$ 000)^{(1)]}$ & $\ddot{-}$ & $\begin{array}{l}23 \\
23 \\
\end{array}$ & $\begin{array}{l}2.4 \\
2.4 \\
\end{array}$ & $\begin{array}{l}2.5 \\
2.5 \\
\end{array}$ & $=$ & $\begin{array}{r}2.2 \\
2.2 \\
\end{array}$ \\
\hline
\end{tabular}

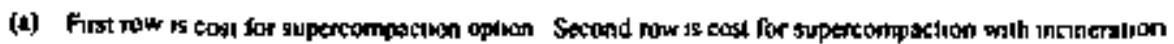

The average trne to DECON a sink and drain is 03 days. The average manpower requirement is I person days. Since the sirks contain virtusily nothing that can be uneinemited, the average cosis were the same, $\$ 2,400$, for both options. Occupational radiation doses ranged from $9 \times 10^{-4}$ person-rem $101 \times 10^{-5}$ person-rem, depending on the type of contamination.

\subsubsection{Building Surfaces}

Building sutfaces ixclude cellings, walls, and noors. Concrete surfaces are decontaninated to unrestricted release levels. Contaminated material such as filoerboard. floor tules or contrete chipped from walls is packaged, supercorrpacted and/or incinetated, and then shipped to a shallow-land bwial ground. A wosk crew consisting of a foreman sod two technicians is assumed to periosm the work. Postulated procedures used to DECON bulding surfaces are discussed in Appendix D.

\section{Ceilings}

The cellings un the ${ }^{3} \mathbf{H}$, ${ }^{14} \mathrm{C}$ and user laboritories consist of acoustically treated fiberbourd. The ceilings un the remainung laboratories are concrete, coated wilh epoxy paint ( ${ }^{(25} \mathrm{I}$ laboratory), latex paint $\left({ }^{\text {(m) }} \mathrm{Cs}\right.$ laboratory), or acrylic paint ( ${ }^{A 1}$ Am iaberatory). Estimated tíme and minupower requisements, cotal costs, ard oecupationst tadiation doses for decotnumissioning one squate meter of ceiting surface to untestricted release levels for each reftrence laboralory are shown in Tabie 5.10. The average torn to DECON a square meter of surlace is 0.03 days The average manpower requarement is 0.13 person days. Cosis a verage $\$ 260$ for supercorrpaction and $\$ 340$ for supercompaction with incineration. Occupstional radiation doses range from $1 \times 10^{-4}$ person-rem to $3 \times 10^{-4}$ person-rem, dependimg on the type of conlamination.

Walls

The walls in the ${ }^{3} \mathrm{H},{ }^{14} \mathrm{C}$, and user laboratories consist of plasterboard painted wth latex enamel. The walis in the remaining laboratories are concrete, costed with epoxy paint ('2'I laboralory), latex paint ('"'Cs laboratory), of acrylic paint (" ${ }^{34}$ Am bboratory). Estumated tirne and manpower regusements, total cosis, and occupational radiation doses for decommissioning ose square meter of wall surface to unrestricted release levels for each reference laboratory art shown in Table 5.11 . The average tume to DECON a square meter of surface is 0.03 days. The average manpower requirement is 0.13 person days. Costs average \$220 for supercompaction and \$250 for supercompaction with incineration. Occupational tadiation doses range from $5 \times 10^{-8}$ person-cern to $3 \times 10^{-4}$ personretrin, depending on the type of contamulation.

\section{Floors}

All of the floors are covered with aspball tile except the floor in the ${ }^{24}$ Am laboratory, which is sovered with 
Tobs 5,10 Summary of esttmated monpower requirements, oceupational radiation dose, and total costs for DECON of one square meter of cejling area

\begin{tabular}{|c|c|c|c|c|c|c|}
\hline & \multicolumn{6}{|c|}{ Laboratory } \\
\hline & ${ }_{\mathbf{H}}$ & ${ }^{14} \mathrm{C}$ & $\mathbb{1 1}_{\mathbf{I}}$ & ${ }^{15} \mathrm{Cs}$ & ${ }^{341} \mathrm{Am}$ & User lab \\
\hline Time (days) & 0.03 & 0.03 & 0.04 & 0.04 & 0.04 & 0.03 \\
\hline Manpower (pers-days) & 0.11 & 0.11 & 0.14 & 0.16 & 0.14 & 0.13 \\
\hline Radiation dose (person-rem) & $1 \times 10^{7}$ & $6 \times 10^{4}$ & $1 \times 10^{6}$ & $2 \times 10^{4}$ & $3 \times 10^{-4}$ & $1 \times 10^{-\pi}$ \\
\hline $\operatorname{Cos}\left(5(\operatorname{sen} 0)^{1 / 0)}\right.$ & $\begin{array}{l}0.20 \\
0.26 \\
\end{array}$ & $\begin{array}{l}0.20 \\
0.26\end{array}$ & $\begin{array}{l}0.25 \\
0.29 \\
\end{array}$ & $\begin{array}{l}0.40 \\
0.53 \\
\end{array}$ & $\begin{array}{l}0.21 \\
0.25\end{array}$ & $\begin{array}{l}0.29 \\
0.42\end{array}$ \\
\hline
\end{tabular}

(b) First row is cos for supereamparion ophof second row is cost for supenconpaction wath incineration.

Table S.11 Summary of estimated manpawer requirements, occupational radiatlon dose, and total costs for DECON of ane square meter of wall area

\begin{tabular}{|c|c|c|c|c|c|c|}
\hline & \multicolumn{6}{|c|}{ Latboralory } \\
\hline & ${ }^{3} \mathbf{H}$ & ${ }^{14} \mathrm{C}$ & $\mathrm{w}_{\mathrm{I}}$ & ${ }^{1} \mathrm{Cs}$ & 2ul Am & User la \\
\hline Time (days) & 0.03 & 0.03 & 0.04 & 0.04 & 0.03 & 0.05 \\
\hline Marpower (pers-days) & 0.10 & 0.10 & 0.14 & 0.14 & 0.13 & 0.18 \\
\hline Radiation dose (person-rem) & $1 \times 10^{+}$ & $5 \times 10^{-1}$ & $1 \times 10^{4}$ & $2 \times 10^{-6}$ & $3 \times 10^{-1}$ & $1 \times 10^{-3}$ \\
\hline Costs $(5000)^{60}$ & $\begin{array}{l}0.17 \\
0.20 \\
\end{array}$ & $\begin{array}{l}0.18 \\
0.21\end{array}$ & $\begin{array}{l}0.25 \\
0.28\end{array}$ & $\begin{array}{l}0.25 \\
0.28 \\
\end{array}$ & $\begin{array}{l}0.19 \\
0.22\end{array}$ & $\begin{array}{l}0.26 \\
0.30 \\
\end{array}$ \\
\hline
\end{tabular}

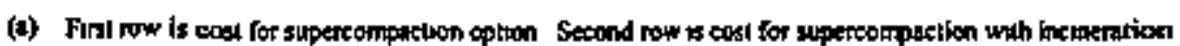

linoleum with beat-treated searrs, Becinuse the linotend is free from eracks, it ts casier to decortaminate and requires less reckeaning than do the asphall tile flocers.

Estimated time and manpower requirenents, total costs, and oceryational radiation doses for decommissioning one $\$$ quare meter of wall surface to unrestricted celease levels for each reference laboratory are stown in Tabte 5.12. The 2verage time to DECON a square neter of surface is 0.04 days. The average manpower reguivenent is 0.15 person days. Costs average $\$ 200$ for superconpaction and $\$ 210$ for supercompaction wtih incineration. Oceopational radiation doses range from $2 \times 10^{4}$ persoos-rem to $7 \times 10^{-4}$ person-rem, deperding on the type of contamination. 
Decommissioning of Facility Components

Table 5.12 Summary of eslíngted manpower requirements, occupastonal radiation dose, and total costs for DEC $O N$ of one square meter of foor area

\begin{tabular}{|c|c|c|c|c|c|c|}
\hline & \multicolumn{6}{|c|}{ Laboralory } \\
\hline & ${ }^{\prime} \mathbf{H}$ & ${ }^{14} \mathrm{C}$ & ${ }^{135} \mathbf{I}$ & ${ }^{135} \mathrm{Cs}$ & ${ }^{241} \mathrm{Am}$ & User Lab \\
\hline Time (days) & 0.04 & 0.04 & 0.04 & 0.04 & 0.04 & 0.04 \\
\hline Manpower (pers-days) & 0.15 & 0.15 & 0.15 & 0.16 & 0.15 & 0.16 \\
\hline Radiation dose (person-rem) & $2 \times 10^{\circ}$ & $7 \times 10^{8}$ & $8 \times 10^{7}$ & $3 \times 10^{\circ}$ & $7 \times 10^{4}$ & $2 \times 10^{-3}$ \\
\hline $\operatorname{Cos} 15\{\$ 000\}^{\{t}$ & $\begin{array}{l}0.17 \\
017 \\
\end{array}$ & $\begin{array}{l}0.19 \\
0.19\end{array}$ & $\begin{array}{l}0.21 \\
0.21 \\
\end{array}$ & $\begin{array}{l}0.23 \\
0.23 \\
\end{array}$ & $\begin{array}{l}0.22 \\
0.26 \\
\end{array}$ & $\begin{array}{l}0.19 \\
0.20 \\
\end{array}$ \\
\hline
\end{tabular}

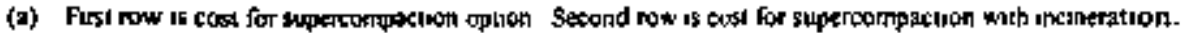

\subsection{References}

I. E. S. Murphy, 1981. Techimology, Sofegy, and Costs of Decommissioning Reference Non-Fwel-Cycle Nuctear Focilities. NUREG/CR-j754, U.S. Nuclear Regulatory Conurussion Report by Pactíc Northwest Laboratory, Richland, Washington. 


\section{Decommissioning of Reference Facilities}

Estimated time and manpower requirements, occupational radiation doses, and total costs for decommissioning exarmple laboratories that process or use rodioisotopes are surnurarized in this chapter. The analysis uses cose data for decommitssioning lsboralory companerts summurized in Chapter 5. The reference lahoratories ane described in Section 7 of NUNEG/CR-1754 (1) and finclude:

- aboralory for the manufacture of ${ }^{3}$ H-labeled compounds

- a laboratory for the manufacture of "C-labeled comporinds

- a laboratory for the manufacture of "2tJ-labeled compounds

- a laboratory for the manufacture of ${ }^{157} \mathrm{C} s$ sealed sources

- a laboralory for the manufacture of "21Am sezled soureses

- a Inboratory for preparing labeled compounds and radioactive sources and using these matedials in experiments with small animals (the reference institutional user (aboratory).

The lectnitcal approach used for this anzlysis is described in Section 6.1. The results of decommtissioning analyses for the tix reference laboratories are presented in Section 6.2. Detalls of manpower and of waste management requirements and costs for decomm'ssionting the six reference laboralories are given in Appendix $\mathbf{D}$.

\subsection{Technical Approach}

The technical approach and some of the they boses used to define requirements and to estimate cosks and safecty of decommissioning the six reference lshoratories are discussed in this section.

\subsubsection{Costs}

Cosis far deconamissioning the reference laboratories include the costs of staff labor, equipreat, supplies, and waste managemenl (the packaging, transportation, and disposal of cadiosctive waste). Esltmates of costs for decomyzissioniag the reference laboratoties are based on estimates of costs for deconornissioning tabaratory components summarized in Chapter 5 from Appendix C. Cost estimating bases are listed in Appendix A. Algorithms for estimating task completion times are given in Appendix B. All costs are expressed in Janutary 1998 dallars.

Each reference laboratory is assumed wo becotmis sioned by employees of the owners ar operators of the laboralory. The basie decommissioning work crew is assumed to consist of a foreman and two technicians. assisted half-time by a health physicist. Craftsmen (electricians and pipefiters) are added o this crew on a part-time basis to perform specific tasts. Manpower costs are dekermined by multiplying work atw times by the hourly charge-ort rate per crew. Mappower costs include the salary of a supervisor on a half-sime basis.

To delermine the time for decommissinting, an estimate is made for the time required for ofticient performance of the work by the postulated work crew. This time estimate is then brezeased by $\mathbf{5 0 \%}$ to provide for preparation and setup time and resl periods (ancillary time).

As meptioned in Section 2.6, previons sudies (12) assumed that some of the facility components were to be decontarinated to unrestricted release levels wiste other cont ponents were to be sectioned and packaged for disposal. In the original study. (I) no factlity compcusents were assumed to be compacted. The foltow on sudy $y^{12}$ considered options of compaction and supercompsction.

The present study differs from the previous two studies in that only surfaces are decontarninatad to unrestricted levels; no facility components are decontaminated. Instead, all compenents are to be supercompacted ior incinerated before 
they are buried. For the first option, all compactible waste is sent to a central facility for supercompaction and subsequent burial at an LLW sile. Uncompactible waste is sent directly to the LL,W site. For the second oplion, wasie is sent to a central facility where it is eulher incinerated or supercompacted, as appropriate. For both options, it is assumed that the componenis are sectioned as efficienily as praclicable to fit into 20B-Ister dnims and compacted onslle with a portable compactor. Both options tend to increase the ume and manpower costs of the packaging operations, but mintmize the volume of radoactive waste shipped to the shaliow-land burial ground, and, consequefilly, minimize transportation and waste dispos:al charges that are determined on a volume basts.

Sorte of the reference laboralones contain sinks into which low-level radioactive liquids are discharged. These liquids normally go to a hold-up tank thal might be buned on-sile. When a laboratory with a contaminated sink is decommissioned, it may also be necessary to remove the contam. inated drain line and hold-up tink. The cosl of removal of the drain line and hold-up tank is ant included in the cost analyses of decommissioning the reference laboralones summanzed in this section. Howevex, the cost of decorrmissioning a site on which these iterrs are butied is estimated in Chapter $\gamma$ to be about $\$ 100,000$. This cost should be added to the cost of decommissioning the laboratory for those cases where removal of the drain itine and hold-up tank is required.

\subsubsection{Occupationa! Radiation Dose Estimates}

Estimales of occtpatronal tadiation dose are made for the decomnissioning of each reference laboratery. The estintated worker dose rates that form the bases for oceupauonal dose calculations are shown in Section 8.1 of NUREG/CR-I754. ${ }^{\text {in }}$ These dose rates are in reasonablt agreemenc with experience at 1ypical materals taboralories

\subsection{Decommissioning Analyses}

Results of analyses of time and manpawer requrements, occupational doses, and total costs for decommissioning the six reference laboratories are presented in this section for bolh options discussed in Section 6. I.1. Requirersents and costs for the planning and preparation phase, for the actual deconmissioning phase, and for the fital cadiation survey to demonstrate compliance with unrestricted relense guidelines are presented. Details of mampower and waste minnagement requírements and cosk are given in Appendix $\mathbf{D}$.

\subsubsection{Laboratory for the Manufacture of ${ }^{3} \mathrm{H}$-Labeled Compounds}

The reference laboratory for the mantacture of ${ }^{3} \mathrm{H}$-labeled compounds is described in delail in Secion 7.1.1 of NUREG/CR-1754_ str The floor area of the laboratory is $10 \mathrm{~m}$ by $12 \mathrm{~m}$

Estumated time and manpower requjernents, occupational radiation doses, and cosis for decommisstoning the reference 'H laboratory are shown in Tab]e 6.1, sumpnarized from Tables D.I.a and D.I.b of Appendix D.

Planming and preparation is estimated a require aboul 6 wecks and 70 persor-days of effor befort the star of decommisșıning operations. Decommussionting operations for both optrons are estimated to require about 5 weeks and 101 person-days of effort and to resilt in a total occupational radiation dose of about 0.04 person-rem.

The lotal cost of decomumisstoning the reference laboratory is esumated to be about \$174,000 for the supercompaction option (Option 1) and $\$ \mathbf{1 9 2 , 0 0 0}$ for lis supercompaction' incineratıon optson (Optoon 2). Planning and preparanion activities account for about $17 \%$ of the total cost for Optron I and 15\% for Option 2. Approxirately $49 \%$ and $\mathbf{4 4 \%}$ of the total cost $1 \mathrm{~s}$ for staff labor (inctuding planning and preparation aclivitios and final radiation survey) and approximately $34 \%$ and $40 \%$ is for waste management for the first and second oplions, respecively.

\subsubsection{Laboratory for the Manufacture of "C-Labeled Compounds}

The reference laboratory for the manufaclure of ${ }^{14} \mathrm{C}$-labeled compounds is descnbed un detail in Secton 7.t.2 of NLREGrCR-1754."'th The floor ares of the laboratory is $10 \mathrm{~m}$ by $8 \mathrm{~m}$

Estimsted time and manpower requirements, occupalional radistion doses, and cosls for docommissioning the relerence ${ }^{14} \mathrm{C}$ laboratory are shown in Table 6.2, summarized fiom Tables D.2.a and D.2.b of Appendix D. 
Table 6.1 Sumubary of estimuted values of monpower regulnerients, occupationel madiution doses, and costs For decontumissioning the referemce laborntory for the mentufacturer of H-labeled eompounds

\begin{tabular}{|c|c|c|c|c|}
\hline Parameler & $\begin{array}{l}\text { Ptanning and } \\
\text { preparallon }\end{array}$ & Decommlssioning & $\begin{array}{l}\text { Fnal radiation } \\
\text { survey }\end{array}$ & Total \\
\hline \multicolumn{5}{|l|}{ Supercompation } \\
\hline Time (days) & 30 & 26 & 5 & 61 \\
\hline Manpower (pers-days) & 70 & 101 & 23 & 194 \\
\hline Occupational dose (pers +rem) & $<0.1$ & $<0.1$ & - & $<0.1$ \\
\hline $\begin{array}{l}\text { Cost (S CGO) } \\
\text { Staff labor } \\
\text { Equipunt } \\
\text { Supplies } \\
\text { Waste utanagedient } \\
\text { Subtotals } \\
\text { 25\% Conxingency } \\
\text { Totals }\end{array}$ & $\begin{array}{l}23.5 \\
- \\
\ddot{1 .} \\
23.5 \\
\frac{5.9}{39.4}\end{array}$ & $\begin{array}{r}37.7 \\
20.2 \\
3.7 \\
47.2 \\
108.8 \\
27.2 \\
136.0\end{array}$ & $\begin{array}{l}6.9 \\
- \\
- \\
-1.9 \\
\frac{1.7}{8.6}\end{array}$ & $\begin{array}{r}68.1 \\
20.2 \\
3.7 \\
47.2 \\
139.2 \\
-34.8 \\
174.1\end{array}$ \\
\hline \multicolumn{5}{|l|}{ Supercompation/w inciceration } \\
\hline Time (days) & 30 & 26 & 5 & 61 \\
\hline Manpower (pers-days) & 70 & 101 & 23 & 194 \\
\hline Occupationtal dose (pers-rem) & $<0.1$ & $<0.1$ & - & $<0.1$ \\
\hline $\begin{array}{l}\text { Cost (\$ 000) } \\
\text { Strff labor } \\
\text { Eqqipment } \\
\text { Supplies } \\
\text { Wast thanagenent } \\
\text { Subtotals } \\
\text { 25\% Contingency } \\
\text { Totels }\end{array}$ & $\begin{array}{c}23.5 \\
- \\
- \\
\overline{23.5} \\
\frac{5.9}{29.4}\end{array}$ & $\begin{array}{r}37.7 \\
20.2 \\
3.7 \\
61.8 \\
123.4 \\
30.9 \\
154.3\end{array}$ & $\begin{array}{l}6.9 \\
- \\
- \\
6.9 \\
\frac{1.7}{8.6}\end{array}$ & $\begin{array}{r}68.1 \\
20.2 \\
3.7 \\
61.8 \\
153.8 \\
38.4 \\
1923\end{array}$ \\
\hline
\end{tabular}


Decomprussioning of Reference Facilutes

Table 6.2 Summary af estimated valnes of manpower requirements, occupational radiotion doses, and costs for decoumissioning the reference laboratory for the manufacturer of "C-labeled compourads

\begin{tabular}{|c|c|c|c|c|}
\hline Parameler & $\begin{array}{l}\text { Planuting and } \\
\text { preparation }\end{array}$ & Deconmtissioning & $\begin{array}{c}\text { Final radiation } \\
\text { survey }\end{array}$ & Total \\
\hline \multicolumn{5}{|l|}{ Supercompaction } \\
\hline Time (days) & 29 & 24 & 5 & 58 \\
\hline Manpower (pers-days) & 66 & 90 & 23 & 179 \\
\hline Occupational dose (pers-sem) & $<0.1$ & $<0 \mathrm{I}$ & - & $<0.1$ \\
\hline $\begin{array}{l}\text { Cost (\$000) } \\
\text { Stgff labor } \\
\text { Equipment } \\
\text { Supplies } \\
\text { Waste management } \\
\text { Subtotals } \\
25 \% \text { Contingency } \\
\text { Totals }\end{array}$ & $\begin{array}{c}21.9 \\
- \\
- \\
21.9 \\
5.5 \\
27.4\end{array}$ & $\begin{array}{r}33.5 \\
20.2 \\
3.2 \\
46.9 \\
103.8 \\
26.0 \\
129.8\end{array}$ & $\begin{array}{c}6.9 \\
- \\
- \\
6.9 \\
\frac{1.7}{8.6}\end{array}$ & $\begin{array}{r}62.3 \\
20.2 \\
3.2 \\
46.9 \\
132.6 \\
-\frac{33.2}{165.8}\end{array}$ \\
\hline \multicolumn{5}{|l|}{ Suptreompaction/w incineration } \\
\hline Tíme (days) & 29 & 24 & 5 & 58 \\
\hline Manpower (pers-days) & 66 & 90 & 23 & 179 \\
\hline Occupational dose (pers-remn) & $<0.1$ & $<0.1$ & -- & $<0.1$ \\
\hline $\begin{array}{l}\text { Cost (\$ 000) } \\
\text { Suff labor } \\
\text { Equipment } \\
\text { Supplies } \\
\text { Waste management } \\
\text { Subtotals } \\
25 \% \text { Contungency } \\
\text { Totals }\end{array}$ & $\begin{array}{c}21.9 \\
- \\
- \\
21.9 \\
\frac{5.5}{27.4}\end{array}$ & $\begin{array}{r}33.5 \\
20.2 \\
3.2 \\
64.7 \\
121.6 \\
30.4 \\
152.0\end{array}$ & $\begin{array}{l}6.9 \\
- \\
- \\
6.9 \\
\frac{1.7}{8.6}\end{array}$ & $\begin{array}{r}62.3 \\
20.2 \\
3.2 \\
64.7 \\
150.4 \\
37.6 \\
188.1\end{array}$ \\
\hline
\end{tabular}


Ptarning and preparntikn is estimated to require about 6 weeks and 66 person-days of effort before the start of decommissionting operations. Decomnissioning operations for both options are estinnaled to require about 5 weeks and 90 person-days of effor and to result in a totat occupalional radiation dose of less than 0.001 person-tem.

The total cost of decorrmissioning the reference laboratory is estimaled to be about $\$ 166,000$ for Option $\downarrow$ and $\$ 188,000$ for Option 2. Planaing and preparation activities account for about $17 \%$ of the tolal cost for Option 1 and 15\% fur Option 2. Approximately $47 \%$ and 41 to of the total cast is for staff labor (including planning and preparation activities and final radiation survey) and approximately $35 \%$ and $43 \%$ is for waste management for the first and second options, respectively.

\subsubsection{Laboratory for the Manufacture of Is'I-Lobeled Compounds}

The refereace laboratory for the manufacture of ${ }^{\text {sy }}$-Labeled compounds is described in detail in Section 7.1.3 of NUREGFCR-1754. ${ }^{\text {II }_{3}}$ The floor area of the lobocalosy is $6 \mathrm{~m}$ by $8 \mathrm{~m}$.

Estimated time and manpower requirements, occupational radiation coses, and costs for decommisstoning the reference ${ }^{12} 1$ lebaratory are shown in Table 6.3, summarized from Tables D.3.a and D.3.b of Appendix D.

Flanning and preparation is estimated to reguire about 6 weeks and 66 person-days of etfort before the start of decomrnissioning operations. Decommisstioning operations for both options are estimsted to require about 4 weeks and 70 person-days of effort and lo result in a tolal occupational radiation dose of abxut 0.01 person-rem.

The total cost of decommissioning the reference laboratory is estimated to be about \$129,000 for Option I and S137,000 for Oplion 2. Ptanning and preparation activities accotunt for about $21 \%$ of the total cost for Option 1 and 20\% for Option 2. Approximately 50\% and 48\% of the total cost is for stuff labor (including planning and preparation activities and finsl radiation survey) and approximately $27 \%$ and $32 \%$ is for wasle managernent for the first and second options, respectively.

\subsubsection{Laboratory for the Manufacture of ${ }^{157} \mathrm{Cs}$ Sealed Sources}

The reference laboratory for the manufature of ${ }^{13} \mathrm{Cs}$ sealed sources is described in detait in Section 7.1.4 of NUREGKCR-1754." The floor area of the laboratory is $6 \mathrm{~m}$ by $8 \mathrm{~m}$.

Estimated time and manpower requirements, occupational radiation doses, and costs for decemnissioning the reference ${ }^{137} \mathrm{Cs}$ laboratory are shown in Table 6.4, summarized from Tables D.4.a ayd D.4.b of Appeadix D.

Planning and preparation is estimated to rexuire about 6 weeks and 63 person-days of effor before the start of decommissioning operations. Decommissioning operations for both options are estimated to require about 4 weeks and 67 person-days of effort and to result in a total oscupa. tional cadiation dose of about 4 person-rem.

The total cost of decommisstioning the reference laboratory is estimated to be about $\$ 155,000$ for Option 1 and $\$ 169,000$ for Option 2. Planning and preparation activities account for about 17\% of the total cost for Option 1 and $15 \%$ for Option 2 . Approximately $40 \%$ and $37 \%$ of the tolal cost is for staff labor (including planning and preparation activities and final radiation survey) and approximately $42 \%$ and $47 \%$ is for waste management for the first and second options, respectively.

\subsubsection{Laboratory for the Manufacture of 24 Am Sealed Sources}

The reference laboratory for the manefacture of $241 \mathrm{Am}$ sealed sources is described in detail in Section 7.1.5 of NUREG/CR-1754 (1) The floor aren of the labomatory is $7 \mathrm{~m}$ by $9 \mathrm{~m}$.

Estimated time and manpower requirenents, occupational radization doses, and costs for decoramissioning the reforence 34 Am laboratory are shown in Table 6.5. summarized from Tables D.5. a and D.5.b of Appendix D.

Planning and preparation is estimated lo require abour 6 weeks und 69 person-days of effoct before the stat of decommissikning operations. Decomraissioning operations 
Table 6.3 Summary of estimated values of manpower requirements, occupational radtation doses, and costs for decommlssloning the reference taboratory tor the manufacturer of 121-labeled compounds

\begin{tabular}{|c|c|c|c|c|}
\hline Parameter & $\begin{array}{l}\text { Plapuing and } \\
\text { preparation }\end{array}$ & Decommissiouing & $\begin{array}{c}\text { Final radlation } \\
\text { survey }\end{array}$ & Total \\
\hline \multicolumn{5}{|l|}{ Supercompaclion } \\
\hline Time (days) & 29 & 18 & 3 & 50 \\
\hline Manpower (pers-days) & 66 & 70 & 14 & 150 \\
\hline Occuparional dose (pers-rem) & $<0.1$ & $<0.1$ & - & $<0.1$ \\
\hline $\begin{array}{l}\text { Cost ( } \$ 000) \\
\text { Stoff labor } \\
\text { Equipment } \\
\text { Supplzes } \\
\text { Waste Management } \\
\text { Subtotals } \\
25 \% \text { Contingency } \\
\text { Fotats }\end{array}$ & $\begin{array}{c}21.9 \\
- \\
- \\
21.9 \\
\frac{5.5}{27.4}\end{array}$ & $\begin{array}{r}25.9 \\
20.2 \\
2.6 \\
28.3 \\
77.0 \\
\frac{19.3}{96.3}\end{array}$ & $\begin{array}{l}4.2 \\
- \\
- \\
4.2 \\
\frac{1.1}{5.3}\end{array}$ & $\begin{array}{r}52.0 \\
20.2 \\
2.6 \\
28.3 \\
103.1 \\
25.8 \\
128.8\end{array}$ \\
\hline \multicolumn{5}{|l|}{ Supercompaction/w lncinetation } \\
\hline Tume (days) & 29 & 18 & 3 & 50 \\
\hline Manpower (pers-days) & 66 & 70 & 14 & 150 \\
\hline Occupational dose (pers-rem) & $<0.1$ & $<0 . t$ & -- & $<0.1$ \\
\hline $\begin{array}{l}\text { Cost }(\$ 000) \\
\text { Staff labor } \\
\text { Equipment } \\
\text { Supplies } \\
\text { Waste managernent } \\
\text { Submothls } \\
25 \% \text { Contingethcy } \\
\text { Totals }\end{array}$ & $\begin{array}{l}21.9 \\
- \\
- \\
\frac{-}{21.9} \\
\frac{5.5}{27.4}\end{array}$ & $\begin{array}{r}25.9 \\
20.2 \\
2.6 \\
34.6 \\
83.3 \\
20.8 \\
104.1 \\
\end{array}$ & $\begin{array}{l}4.2 \\
- \\
- \\
4.2 \\
\frac{1.1}{5.3}\end{array}$ & $\begin{array}{r}52.0 \\
20.2 \\
2.6 \\
34.6 \\
109.4 \\
27.4 \\
136.7\end{array}$ \\
\hline
\end{tabular}


Table 6.4 Summary of estimated values of manpower requirements, occupqutionat radiotion doses, and costs for decommisstonting the reference bhoretary far the minufacturer of ${ }^{13}$ Cs sealed sources

\begin{tabular}{|c|c|c|c|c|}
\hline Parameter & $\begin{array}{l}\text { Planning and } \\
\text { preparation }\end{array}$ & Decommissioning & $\begin{array}{l}\text { Final ratiatlon } \\
\text { survey }\end{array}$ & Total \\
\hline \multicolumn{5}{|l|}{ Supertompaction } \\
\hline Time (days) & 28 & 18 & $\mathbf{3}$ & 48 \\
\hline Manpower (pers-days) & 62 & 67 & 14 & 143 \\
\hline Oxcupatisnal dose (pers-rem) & 0.4 & 3.8 & - & 4.2 \\
\hline $\begin{array}{l}\text { Cost }(\$ 000) \\
\text { Siaft lebor } \\
\text { Equipanent } \\
\text { Supplies } \\
\text { Waste mantgoment } \\
\text { Subxotais } \\
\text { 25\% Contingency } \\
\text { Totals }\end{array}$ & $\begin{array}{l}20.8 \\
- \\
- \\
20.8 \\
\frac{5.2}{26.0}\end{array}$ & $\begin{array}{r}24.9 \\
20.2 \\
2.3 \\
51.8 \\
99.2 \\
24.8 \\
124.0\end{array}$ & $\begin{array}{l}4.2 \\
+ \\
+4.2 \\
\frac{1.1}{5.3}\end{array}$ & $\begin{array}{r}49.9 \\
20.2 \\
2.3 \\
51.8 \\
124.2 \\
31.1 \\
155.3\end{array}$ \\
\hline \multicolumn{5}{|l|}{ Supercompaction/w Incintration } \\
\hline Timo (days) & 28 & 18 & 3 & 48 \\
\hline Manpower (pers-days) & 62 & 67 & 14 & 143 \\
\hline Oxcopational dose (pers-rem) & 0.4 & 3.8 & - & 4.2 \\
\hline $\begin{array}{l}\text { Cost (\$ OOO) } \\
\text { Staff labos } \\
\text { Equipment } \\
\text { Supplies } \\
\text { Waste management } \\
\text { Subcotals } \\
25 \% \text { Contingency } \\
\text { Totais } \\
\end{array}$ & $\begin{array}{l}20.8 \\
= \\
- \\
\overrightarrow{20.8} \\
\frac{5.2}{26.8}\end{array}$ & $\begin{array}{r}24.9 \\
20.2 \\
2.3 \\
63.0 \\
110.4 \\
27.6 \\
138.0 \\
\end{array}$ & $\begin{array}{l}4.2 \\
- \\
- \\
4.2 \\
\frac{1.1}{5.3}\end{array}$ & $\begin{array}{r}49.9 \\
20.2 \\
2.3 \\
6.30 \\
135.4 \\
33.9 \\
169.4 \\
\end{array}$ \\
\hline
\end{tabular}


Decommtssioning of Reference Facilities

Table 6.5 Sumuary of estimated values of manpower requirement, occupatlonal rediation doses, and costs for decommissioning the reference laboratory for the manufacturer of ${ }^{2 \pi}$ Am sealed sources

\begin{tabular}{|c|c|c|c|c|}
\hline Parameter & $\begin{array}{l}\text { Planning and } \\
\text { preparation }\end{array}$ & Decummissloning & $\begin{array}{c}\text { Final radiation } \\
\text { survey }\end{array}$ & Total \\
\hline \multicolumn{5}{|l|}{ Supercompacion } \\
\hline Tìmt (days) & 30 & 23 & 5 & 58 \\
\hline Manpower (pers-days) & 68 & 88 & 23 & 179 \\
\hline Occupational dose (pers-rem) & 1.8 & 11.7 & -- & 13.5 \\
\hline $\begin{array}{l}\text { Cosi }(\$ 000) \\
\text { Stafr labor } \\
\text { Equipment } \\
\text { Supplies } \\
\text { Waste management } \\
\text { Subtotals } \\
25 \% \text { Contingency } \\
\text { Todals }\end{array}$ & $\begin{array}{l}22.9 \\
- \\
- \\
11 \\
22.9 \\
\frac{3.7}{28.6}\end{array}$ & $\begin{array}{r}326 \\
20.2 \\
3.2 \\
31.5 \\
87.5 \\
21.5 \\
109.4\end{array}$ & $\begin{array}{l}6.9 \\
- \\
- \\
6.9 \\
\frac{1.7}{8.6}\end{array}$ & $\begin{array}{r}62.4 \\
20.2 \\
3.2 \\
31.5 \\
117.5 \\
29.3 \\
146.8\end{array}$ \\
\hline \multicolumn{5}{|l|}{ Supercornpaciòn/w lncineration } \\
\hline Titme (days) & 30 & 23 & 5 & 58 \\
\hline Manpower (pers-days) & 68 & 88 & 23 & 179 \\
\hline Occupational dose (pers-rem) & 1.8 & 11.7 & - & 13.5 \\
\hline $\begin{array}{l}\text { Cost (5 000) } \\
\text { Staff labor } \\
\text { Equipment } \\
\text { Supplis } \\
\text { Waste management } \\
\text { Subtotals } \\
25 \% \text { Contingency } \\
\text { Totals } \\
\end{array}$ & $\begin{array}{l}22.9 \\
- \\
- \\
\frac{1}{22.9} \\
\frac{5.7}{28.6}\end{array}$ & $\begin{array}{r}32.6 \\
20.2 \\
3.2 \\
41.8 \\
97.8 \\
2.4 .5 \\
122.3 \\
\end{array}$ & $\begin{array}{l}6.9 \\
- \\
- \\
6.9 \\
\frac{1.7}{8.6}\end{array}$ & $\begin{array}{r}62.4 \\
20.2 \\
3.2 \\
41.8 \\
127.6 \\
31.9 \\
159.7 \\
\end{array}$ \\
\hline
\end{tabular}


for both options are estimaled to require about 5 weeks and B8 person-days of effoct and to result in a 1otal occupational radiation dose of about 12 persoti-sem.

The total cosl of deconmissioning the reference laboratory is estimated to be about \$147,000 for Option I and $\$ 160,000$ for Option 2. Planning and preparation activities account for abour 19\% of the total cost for Option 1 and $18 \%$ for Option 2. Approximately $53 \%$ and $49 \%$ of the lotal cost is far staft labor (including planning and preparation activities and final radiation survey) and approximately $27 \%$ and $33 \%$ is for waste management for the first and second options, respectively.

\section{6,2.6 Institutional User Laboratory}

The referente institulional user laboratory is described in detsil in Section 7.2 of NUREGCR-1754," The florr area of the labocalory is $11 \mathrm{~m}$ by $16 \mathrm{~m}$. Estimated time and manpower requirements, occupational radiation doses, and costs foc decommissioning the reference instintionsl tuser laboratory are shown in Twble 6.6, suminarized from Tables D.6.a and D.6.b of Appendix D.

Planning and preparalion is eslimated to require about 6 weeks and 70 person-days of elfort before the stant of decommisstoning operations. Decommissioning operatioxs for both options are estirnated to require thout 6 weeks and 114 person-days of effort and to result in a tota recupstional radiation dose of abont 1.4 person-rem.

The totat cosl of decommissioning the reference labotalory is estimated to be about \$205,000 for Option I and 5237,000 for Option 2. Plaming and preparation activities account for about 14\% of the total cosl for Option I and 12\% for Option 2. Approximalely $47 \%$ and $41 \%$ of the total cost is for stoff labor (Including planning and preparation activities and final radiation survey) and approximately $38 \%$ and $46 \%$ is for waste management for the first and second options, respectively.

\subsection{Analyses and Conclusions}

How does the methodology used in this report compare with real-wotk costs? In general, it is extremely difficult to obtain detailed data on the actual costs of decomrnissioning a facility since cosis actually expended on deconrissioniog aro usually considered to be proprietary, especially if a decomusissioning opertions contractor was contracted (competitively) to do the wotk.

In Chapter 3, three facifitites actually deconurissioned in the last tive years were discissed. (These three were representative of the range of types of facilities requiring decommissioning.) In each case, the lotal cost of docommissioning the facilities was avaitable, but no breakdown of these costs into calegortes was obtainable. However, from the data avallable on two of these facilities, the Battelle Bullding KA-3 and INS handry facilidy. a rough independent estimate using the thodology in this rtport was made. These results are presenled in Table 6.7. It must be noted, however, that numxerous judgements about the requirements for decomursissioning ench facility had to be made in order 10 generate an estimate. In the case of the Battelie facility particularly, it is known that a nutmber of non-supporting walls were completely nemoved rather than be decontaminated, that extensive grouling of the stil bentealth the burilding was reguired to provide sufficient foundation suppon to the building during decomunissioning, and that DOE Operalional Safely and Health requirements, in addition to NRC reguirements. were followed during decomarissioning.

Cost compantsons with facilities like the six reference laboratories discussed in this chapter are possible. For example, a tew licensees with decomutrissioning funding plans available in the NRC dockets have sufficient information from whith independent dexomutissioning cost estimated can be generated. Whitle these independent estimates carnot be compared to actual costs incurred fiom decornmissioning, they can at teast be compared to the cost estimates actually provided by the liceasees to the NRC for certification. Results of analyzing five euch facilities suggest the following:

- Costs development by the methodology of this te-port are generally in fairly good agreentem with the licensee-provided estimates (i. $\varepsilon_{\text {, w thin }}$ a band of +50 . $-70 \%$ ). The estimstes using the methodology presented in this report, are greater in 2 aut the 5 cases.

- In the three cases where the methodology estimate is lower than the licensec estimate, the licensee estimate for disposal cost is exceptionally high (from the available information, it is not clear why this would be the cose). 
Decommussioning of Reference Facilities

Table 6.6 Summary af estimated ralues of manpower requlrements, otcupational redtatlon doses, and costs for decommissinaing the reference instlutional user laboratory

\begin{tabular}{|c|c|c|c|c|}
\hline Parameter & $\begin{array}{l}\text { Planning and } \\
\text { preparation }\end{array}$ & Decommissionling & $\begin{array}{c}\text { Final radiation } \\
\text { survey }\end{array}$ & Total \\
\hline \multicolumn{5}{|l|}{ Supercompaction } \\
\hline Time (days) & 30 & 30 & 8 & 68 \\
\hline Manpower (pers-days) & 70 & $1: 14$ & 36 & 220 \\
\hline Occupational dose (pers-rem) & $<0.1$ & $<0.1$ & -- & $<0.1$ \\
\hline $\begin{array}{l}\text { Cost }(\$ 000) \\
\text { Staff laber } \\
\text { Equpment } \\
\text { Supplies } \\
\text { Wasle management } \\
\text { Subtotals } \\
\text { 25\% Contingency } \\
\text { Totals }\end{array}$ & $\begin{array}{l}23.5 \\
- \\
- \\
73.5 \\
\frac{5.9}{29.4}\end{array}$ & $\begin{array}{r}42.6 \\
20.2 \\
4.2 \\
62.3 \\
129.3 \\
32.3 \\
161.6\end{array}$ & $\begin{array}{l}11.1 \\
-- \\
- \\
11.1 \\
2.8 \\
13.9\end{array}$ & $\begin{array}{r}77.2 \\
20.2 \\
4.2 \\
62.3 \\
163.9 \\
410 \\
204.8\end{array}$ \\
\hline \multicolumn{5}{|l|}{ Supercompaction/w Incineration } \\
\hline Time (days) & 30 & 30 & 8 & 68 \\
\hline Manpower (pers-days) & 70 & t 14 & 36 & 220 \\
\hline Occupational dose (pers-rem) & $<0.1$ & $<0.1$ & - & $<0.1$ \\
\hline $\begin{array}{l}\text { Cost (\$ (000) } \\
\text { Staff labor } \\
\text { Equipment } \\
\text { Supplies } \\
\text { Waste managernent } \\
\text { Sublotals } \\
25 \% \text { Contingency } \\
\text { Toluls }\end{array}$ & $\begin{array}{l}23.5 \\
- \\
- \\
\overline{23.5} \\
\frac{5.9}{29.4}\end{array}$ & $\begin{array}{r}42.6 \\
20.2 \\
4.2 \\
87.6 \\
154.6 \\
38.7 \\
193.3\end{array}$ & $\begin{array}{l}11.1 \\
= \\
= \\
11.1 \\
\frac{2.8}{13.9}\end{array}$ & $\begin{array}{r}77.2 \\
20.2 \\
4.2 \\
87.6 \\
189.2 \\
47.3 \\
236.5\end{array}$ \\
\hline
\end{tabular}


Table 6.7 Compitrison of decommissioning costs for Buttelle and JNS ratilities

\begin{tabular}{lcc}
\hline & \multicolumn{2}{c}{ Cost (\$) } \\
\cline { 2 - 3 } Building & Actual & Estimated \\
\hline Battelle KA-3 & $\$ 25 \mathrm{M}$ & $\$ 8 \mathrm{M}$ \\
INS facility & $\$ 220 \mathrm{~K}$ & $\$ 110 \mathrm{~K}$ \\
\hline
\end{tabular}

- In many of the cases, it is clear that licensees consider the costs associaled with the planting and aclual D\&D of facitities to be a part of their everyday operations (since they alrendy employ the necessary staff and wilt pay them whether it is for these D\&D operations or other on-going operations) and thenefore do not provide estimates for the total cast of performing the decommissioning. By conngarison, the methodology used in the present study intuludes the costs for all activities associated with decommissioning a facility.
From these cornpartsons il can be concluded that the decommissioning cost estimating anthodalogy used in this report is in faisly close agreement will licensee-estimated decorrmissioning cosks. Given the wide varjation in the types and operational histories of facilities categorized as non-fuel-cycle facilities, the methodology used in this report does provide estimeses that are representalive of repl-world decommissioning costs.

\subsection{References}

1. E S. Murphy. 1981. Technolozy, Safety, and Cosss of Decamntissioning Reference Nar-Fuel-Cycle Nuctedr Facilities. NUREGKR-1754, US. Nuctear Reguintory Commission Report by Pacific Northwest Laborakory, Rickland, Wrashington. 


\section{Decommissioning of Reference Sites}

Information on the kectinology, costs, and cocupational radiation doses for decommissioning several example sites is presented in this chapler. The reference sites chosen for analysis are (1) a site with a contaninaled underground drain Ure and hold-up tank, (2) a site with a contaminated ground surface, and (3) a tiilings pile/evaporation pond containing uranjum atsd thorium residues. These siles are described in Section 7,3 of NUREG/CR-1754, (1)

The technical approach cused to estimalc tequirenents, casts, and safety is described in Section 7.1. The results of docommissionting analyses for individual siles are presented in Section 7.2. Details of doconntrissioning the reference sttes are presented in Appepdix E.

\subsection{Technical Approach}

The tectinicel approach and most key bases used to define requirements and estimate costs and saifty of decommissivening the feference sites have not changed sinct publicotion of NUREGCCR-1754 $4^{13}$ and can be found in Section 10.1 of that document. New of revised bases are discussed betow.

\subsubsection{Cost Estimates}

Costs estitnates tre made int this sludy for the deconmissioning of three example sites: (I) a sife with a contarninsted underground drain lince and hold-ug tank, (2) a site with a contaminaled ground surfiee, and (3) a tailings piledevaporation pond contrining uranium and thoriem residues. For the first two stites, it is assismed that unrestricted relense of the sites is desirsble. Therefore. costs are estimated for exhurnation of the contaminated waste and soil and disposal of the material at a shallow+land burlal ground. Fot the tailings pilefevaporation pond, costs are estimated for both the site stabilizalion and the removal options. Costs are expressed in Japuxry 1998 dotlars and isclude a 25\% costingency. Some key bases and essumptions for estimating coses are given in Appendix $A$. Cost estimating bases are also given in Appendix A.

Total costs include the costs of labon, equipment, materiaks, and waste manigement (the packíng, trunsportalion, and disposal of radionctive material removed from the site). Because transportation to and disposal at a shallow-land burial ground are contracted activities, Iabor costs for transportation and disposal are included in the total costs of these items.

Labor costs are determined by multippying the person-days required to decommission a site by the cost per person-day shown in Table A.J in Appendix A. For ease in evaluating time and labor requirements, site decommissioning is divided into a sequence of tasks or steps. For the site stabilization option, 1bese steps are:

- planning and preparation (includung initial site survey)

- mobilization/demobilization

- sìle stabilization

- revegetation.

For the removal option, these steps are:

- planting and preparation (including initial sitte aurvey)

- mobilization/demobilization

- remove overbunderi

- exhume and package contaminated malertal

- transport and dispose of contaminaled material a1 a shallow-land burzal ground

- backfill and restore site

- final site survey.

To determine the total time required to decommission a site, an estirmate is made of the time required for efficiert performetice of the work by the postulated work enew. This time estimate is thes increased by $50 \%$ to provide for preparation end sel-up time, rest periods, ete. (ancillary time)- 
The ownetioperatos of a ste is assumed to pertorm his own site survey. (Soil samples are analyzed by a commercald. Laboratory.) Site stabilization or waste and soil removal activities are assumed to be performed by a contractor hirced by the ownefioperator of the site. The impact on decommissıoning cosis of utilizing a tontractor is discussed in Seclion D.I of NUREG/CR-1754. "1' The contractor is onticipaled to reccive payment consisting of reimbursement for expenses (1.e., labor, equipmert, and materisl cosis). plus a fee lo provide a teasonable profit tor tins efforts. For this study, the contrater's tee is calculated on the basis of $B$ of of the sum of his labor, equpment, matersal, and packaging costs. This rate is judged to be reasonable for the size anot complexity of the decommissioning projects. Transportation and disposal tasks are performed by separate contracters hired by the site ounetroperator.

Overhead rates applied to staff labar are expecled to be sıgnificantly higher for the decommissioning contractor than they refe for the sile ownerfoperator. These higher overhead rales apply because of the larger ralio of super visory and support personnel to disect labor that usually exists in contractor organizations and becatise of travel and living expentes associated with having personitel in the field rather than in an offece. In Table A.1 in Appendix A. an overbead rate on direct staff labor of $110 \%$. plus $15 \%$ peofit on labor and its overheads, is spplied for all conractor personnel. The work crew for site decommissioning opertions consists of a supervisor (assigned to the project on a half-1ime basis), a foreman, equipment operators, inick drivers, and techricians who are part of the contractor's staff; and a bealth physictst from the ownertoperalor's staff.

Monthly charges for equipment used by the decommissioning contractor are calculaled on the basis of rental from equipment dealers. Rental rates are based on the capital cost of the equipment and include altowances for equipment deprecialion, maintenance and operating expenses (e.g. fuel, Jubrication, tec.), the cost of decontaminaton following use, and retum on invesimem. The equipment costs do not include the operator's wage. Weekly charges are estimbted to be approximately one-thind of the monthly charges.

Mobilization and demobilization costs are determined by estimating the times required for lhese aclivities. Costs of labor and equipmenl are adjusled to melude these time periods as well as uhe sclual time spent decommissioning the site.

\subsection{Decommissioning Analyses}

Results of analyses of time and labor requirements, total costs, and oecupational radiation doses for decommissioning three reference siles are presented in this seclion. The sites and the deconmissioning options evaluated are shown in Table 7.J. Total costs of decommissioning include the costs of labor, equipment, materials, waste man+ agement (e-g, the packaging. transportation, and disposal of radionclive waste), and contractor's fees where appliesble.

Details of time and labor requirements and of total costs for decommissioning the reference sites are preseried in Appendix E.

Table 7.1 Decommissisning options for reference sites

\begin{tabular}{|c|c|c|}
\hline & \multicolumn{2}{|c|}{ Decourinissioninie oplen } \\
\hline Silfe & $\begin{array}{c}\text { Stt } \\
\text { strbilluntiog }\end{array}$ & Rewnit \\
\hline $\begin{array}{l}\text { Undergicund thain the and bold- } \\
\text { bp bnk }\end{array}$ & & $x^{m 1}$ \\
\hline Conteminated ground surface & & $x$ \\
\hline Twilıngs puTefevaparaboa pood & $x$ & $x$ \\
\hline
\end{tabular}

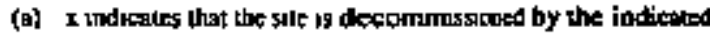
opion.

\subsubsection{Contaminated Underground Drain Line}

The reference contaminated under ground drain line consists of $20 \mathrm{~m}$ of $0.1-\mathrm{m}-\mathrm{d}$ ameter cust-ison pipe and a 1.5-m-diemeter by 2-m-high cylindncal steel tark.

Estimated time and tabor requirements, tota] costs, and cocupational ralintion doses for removal of a contaminated 
drain lins, hold-up tank, and soil are presented in Table 7.2, summatized frow Section E.I of Appendix E. Of the toral of 17 work days required for this waste removal operation. 5 work days are required for planning and preparation activities (including the initial radiation survey) that precede the actual decommissionting operalions. The total cost of decommissioning is estimated to be about \$126,000. Oxcupational radiation doses are estimated to total about O.l person-rem, based on an average worker tose rate of 0.1 mrembr.

Details of waste removal operations are given in Section G.2 of NUREG/CR+1754." (1) The dratin tine is cut into 2-m sections for ease of packaging. The hold-up tank is packaged as a unit without cutting. After removal from the ground, the drain line, hold-up tunk, and $2 \mathrm{~m}^{3}$ of contaminsled wil are packaged in 208-liter drums and shipped by truck to a disposel site.
Cast details are presented in Table E.2 of Appendix $E$. Labor costs iepresent about $\mathbf{4 2 \%}$ of the total decommissioning cost. Costs of the initial ind fonal site surveys (including Jabor, equipment, soil andysis cosis) are about $2 t \%$ of the total cost.

\subsubsection{Contaminated Ground Surface}

The reference site comaining contanisated ground surface occupies an area of about $40,000 m^{2}$ and contains approxt. mately $1000 \mathrm{~m}^{3}$ of contaminated soil.

Estimated time and labor requiremenks, total costs, and occupational radiation doses for the removal of coniaminzted soil from the surface of a reference site are presented in Table 7.3, summarized from Seetion E.2 of Appendix E.

Table 7.2 Sum:mary of estimated labor requirenaents, cosks, and accupational radiatlon doses for the rerroval of a contenninted drain liof and holdoup task

\begin{tabular}{|c|c|c|c|c|}
\hline Parameler & $\begin{array}{l}\text { Plomping o } \\
\text { preparatlon }\end{array}$ & Decommissiloning & $\begin{array}{l}\text { Fintul } \\
\text { radilation } \\
\text { surveg }\end{array}$ & Tolats: \\
\hline Time (days) & 5 & 10 & 2 & 17 \\
\hline Labor (person-days) & 15 & 505 & 7 & 72.5 \\
\hline Occupational dose (person-rem) & $<0.1$ & $<0.1$ & 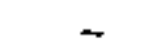 & $0 . \mathrm{I}$ \\
\hline \multicolumn{5}{|l|}{ Costs $(\$ 000)^{(-)}$} \\
\hline Staff labor & 5.6 & 27.4 & 2.6 & 35.6 \\
\hline Equjpmęnt & 1.9 & 12.9 & 1.0 & 15.8 \\
\hline Materials & 0.5 & 4.0 & 0.2 & 4.8 \\
\hline Soìl analyses & 6.0 & - & 2.4 & B. 0 \\
\hline Contractor's feet & - & 3.7 & - & 3.7 \\
\hline Waste management & - & 329 & $=$ & 32,9 \\
\hline Subiotnd & 14.0 & 80.9 & 5.8 & 100.7 \\
\hline 25\% Cortingency & 3.5 & 20.2 & 1.5 & 25.2 \\
\hline Tolals & 17.5 & 101.1 & 7.3 & 125.9 \\
\hline
\end{tabular}

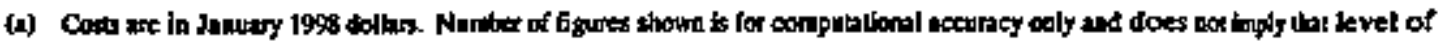
pitciston. 
Decommissioning of Reference Sites

Table 7,3 Surnmary of estinaterd labor requirements, costs, and occupational radistion doses for the removal of contaminated soll from a reference șite

\begin{tabular}{|c|c|c|c|c|}
\hline Paranoter & $\begin{array}{l}\text { Pansing \& } \\
\text { preparation }\end{array}$ & Decommissloning & $\begin{array}{l}\text { Final } \\
\text { radiation } \\
\text { survey }\end{array}$ & Totals \\
\hline Tìms (days) & 20 & 17 & 5 & 42 \\
\hline Labor (person-days) & 75 & 111.5 & 22.5 & 209 \\
\hline Occupation dose (person-rem) & $<0.1$ & 0.1 & - & D.1 \\
\hline \multicolumn{5}{|l|}{ Costs $(\$ \infty X 0)$} \\
\hline Sinff labor & 27.4 & 56.4 & 8.2 & 92.0 \\
\hline Equipment & 9.3 & 21.0 & 1.5 & 31.8 \\
\hline Materials & 2.5 & 12.3 & 0.7 & 15.5 \\
\hline Soil analyses & 90.0 & - & 6.0 & 96.0 \\
\hline Contractor's fee & $r$ & 26.1 & - & 26.1 \\
\hline Waste management & $=$ & 855.6 & $=$ & 8.55.6.6 \\
\hline Subtotal & 129.3 & 971.4 & 16.4 & 1.117 .0 \\
\hline $25 \%$ Contingency & 32,3 & 242.8 & 4.1 & -279.3 \\
\hline Tot:ls & 161.6 & $1,214.2$ & 20.5 & $1,396.3$ \\
\hline
\end{tabular}

(a) Costs are in Jantary 1998 doltars Number of figures shown as for compulational aceuracy oely and does nor inply that fevel of precision.

Of the total of 42 work days required for this waste removal operstion, 20 work days are requited for planning and prepuration activities (including the initul site survey) thal precede the actual decommissioning operations. The wotal cost of radiological surveys, removal of the contaminaled soil, and restoration of the site is estimated to be about \$; 396,000. Occupational radiation doses are estimated to total about 0.] person-rem, based on an average worker dose rate of 0.1 mrem/hr.

Details of site survey and waste removal operalions are given in Section G.3 of NUREC/CR-1754, th The veterence síte occupies $4 \times 10^{4} \mathrm{~m}^{2}$ (approximately 10 actes). It is assumed to be contaminated with radioaclive residue from uranium proctssing operations, with the ressdue oxiginaliy trucked to the site from another location for use as fill material. Following a radiological survey to locate concentrations of fill moterial, approxumalely $1000 \mathrm{~m}^{3}$ of contaminated soil is removed from the site. This soil is packaged in B-25 meml boxes and shipped to a disposal silc. The site is then backfilled and graded and a final radiological survey is performed to verify the stuitability of the site for urutstricted release. The operations for decommissioning this reference silt are believed to be 1ypical of requirements for the decommissioning of sites where operalions included on-site bunal of radiosclive waste. The costs for on-site disposal could, however, be considerably less than costs for disposal at a shallow-land burial ground. 
Cost details are presented in Table E.4 of Appendix E. Labor costs represetit only about $8 \%$ of the total deconmissioning cost, with wasle management costs (cost of packaging, transportition, and disposal of the exhumed soil) accounting for about $77 \%$ of the total decomrissloning cost. Costs of the initial and final site surveys (tncluding labor, equipmerx, and soil anatysis) are about 12\% of the total cost.

\subsubsection{Tailings Pile/Evaparation Pond}

The reference tailings pite/evaperation pond is located on a 20,000-m $\mathrm{m}^{2}$ site and has dimensions of $100 \mathrm{~m}$ long by $50 \mathrm{~m}$ deep, with $* 2.5$ to 1 stope on each side. The referenee tailings pilelevaporation pond is described in Section 73 of NUREG/CR+1754" "The pile contains the residue from ore refinery operation in which tin slag is processed for the recovery of uiabium and lantalum The tin slag is estimated to contain 0.2 wt $\% \mathrm{U}_{1} \mathrm{O}$, and $0.5 \mathrm{wt} \%$ ThO. The sludge from processing operations, which contains essentially all of the thoritum and ursonium, is pumped to a seltling pond, where the water is atlowed to evaporate, converting the sludge to a glassy solid. Additional information about the reference tailings pile/pond and its contents is shown in Table 7,4.

\section{Table 7,4 Sone characteristics of the refertace} tolings pile/cvaporation pond

\begin{tabular}{ll}
\hline \multicolumn{1}{c}{ Panimeter } & \multicolumn{1}{c}{ Value } \\
\hline Volume of pond & $16,000 \mathrm{~m}^{3}$ \\
Wejght of nsildue & $4.1 \times 10^{\circ} \mathrm{kg}$ \\
$\mathrm{U}_{3} \mathrm{O}_{1}$ concentration & $0.2 \mathrm{w} \%$ \\
Contained $\mathrm{U}_{3} \mathrm{O}_{1}$ & $8.2 \times 10^{\circ} \mathrm{kg}$ \\
ThO $\mathrm{O}_{2}$ concentration & $0.5 \mathrm{wt} \%$ \\
Conlained $\mathrm{ThO}_{2}$ & $2.02 \times 10^{6} \mathrm{~kg}$ \\
\hline
\end{tabular}

Exrimated time and labor requitements, total costs, and occupational doses for decommissioning a tailings pile! evaporation pond by the option of siabijization are presented in Toble 7.S sutwritarized from Section E.3 of Appendix $\mathrm{E}$. The annual requirements and costs of longterm care following stabilization are also shown in Table 7.5. The cost of stabilization is estimaled to be about \$237,000, and the occupatiansl radiation dose for this option Is estimated to be 0.1 person-rem. The annizat cost of long-term carte is estimated to be about $\$ 17,000$, and the anoul occupational radistion dose is estimated to be about 0.02 person-rem

Requirements and costs for removal of the pile/pond are shown in Table 7.6. The cost of remova' of the pile'pond and its disposal at a shallow-land butial ground is estimaied to be about \$23 million, and the occupational radiation dose for this oplion is estirated to be 1.3 person-rem.

Decommissioning begins with planning and preparation activities that include a radiological survey to deteminine the tardiokgiest condition of the pilepond and the site where the pile'pond is located. The sile survey includes measurements of garsura radiation kvels, mensurements of the rate of radon emanation from the pile/pond, and analysis of soil samples.

For the site stabilization option, the following procedures are assumed. The pile/pond is coveted with a 50-murthick layer of asphalt. This asphalt tayer is then covered with I m of soil. The soil is mounded slightly at the center to altow water to drain from the soil cover and to prevent the accurnulation of runoff Jrom rainfall or snow met. After compaction and contoung of the soll cover, the grea is seeded with griss.

About 35\% of the wotal cost of the site stabilization option is for the asphalt and the soil used to estiblish the cover over the pilefpond. Labor costs represent about $39 \%$ of the 1otal cost of this option.

Long-term care activities include adripistrative comrol, site matintenance, environmental strveillance, and vegetation managerrent. Labor costs sepresent almost $66 \%$ of the estimated annuat cost of long-term care.

For the rerroval option, conventional earthunoving equipment is used to exhume the pile/pond. Approximately $16,400 \mathrm{~m}^{3}$ of residue and 3,000 m' of podentisily contaninated soil are packaged in B-25 metal boxes and shipped to a disposal sile. Afit the piletpond is removed, the site ts backftled and graded.

The site is then sunveyed to verify its suitabitity for unrestricted release. Finally, grass is sceded to establish a vegelative cover. 
Decommissioning of Reference Sites

Table 7.5 Sommary of esimated labor requirements, cost5, and oxcupational radiation doses tor the stabilation or a reference tailings pilelevaporation poud

\begin{tabular}{|c|c|c|c|c|}
\hline \multicolumn{5}{|c|}{ Site stabilization } \\
\hline Parameler & $\begin{array}{l}\text { Planning \& } \\
\text { preparatlon }\end{array}$ & Deconmlsstoning & Totpls & $\begin{array}{l}\text { Long-terat care } \\
\text { annual values }\end{array}$ \\
\hline Time (days) & 20 & 12 & 32 & 10 \\
\hline Labor (persoth-days) & 70 & 104 & 174 & 27 \\
\hline Occupational dose (person-rem) & $<0.1$ & 0.1 & 0.1 & 0.02 \\
\hline \multicolumn{5}{|l|}{ Costs $(\$ 000)^{(0)}$} \\
\hline Slaff labor & 22.0 & 51.4 & 73.4 & 8.7 \\
\hline Equipment & 9.3 & $1 \mathrm{t} .9$ & 21.2 & 1.8 \\
\hline Materiais & 20 & 72.5 & 74.5 & 0.8 \\
\hline Soil analyses & 10.0 & - & 10.0 & 2.0 \\
\hline Contracior's fee & $\rightarrow$ & 10.9 & 10.9 & - \\
\hline Waste mantagement & $=$ & $=$ & $\ddot{H}$ & 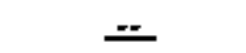 \\
\hline Sublotal & 43.4 & 146.6 & 189.9 & 13.3 \\
\hline $25 \%$ Contingency & $\underline{10.8}$ & 367 & 47.5 & 3.7 \\
\hline Totals & $\$ 4.2$ & 183.3 & 237.4 & 16.6 \\
\hline
\end{tabular}

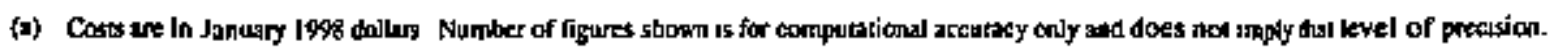


Tyble 7.6 Summary of estlmated labor requbrements, costs, and cocupational radiation dosts for removal of a reference tolitings pllelevaporation pand

\begin{tabular}{|c|c|c|c|c|}
\hline Paranueter & $\begin{array}{l}\text { Planning \& } \\
\text { preporation }\end{array}$ & Decommisstioning & $\begin{array}{c}\text { Find } \\
\text { radintian } \\
\text { survey }\end{array}$ & Tatals \\
\hline Time (days) & 20 & 114 & 5 & 139 \\
\hline Labor (person-days) & 70 & 1569 & 17.5 & 1.656 .5 \\
\hline Occupational dose (persin-rem) & $<0.1$ & 1.3 & - & 1,3 \\
\hline \multicolumn{5}{|l|}{ Costs $(\mathrm{SOONO})^{(0)}$} \\
\hline Staff labor & 22.0 & 785.4 & 6.5 & 813.8 \\
\hline Equipment & 9.3 & 88.4 & 1.5 & 98.9 \\
\hline Materials & 2.0 & 176.6 & 0.6 & 179.2 \\
\hline Soil analytes & 90.0 & - & 6.0 & 96.0 \\
\hline Contracirx' fes & $\leftarrow$ & 452.0 & - & 452.0 \\
\hline Waste manksement & $=$ & $\underline{16.598 .4}$ & $=$ & 16.598 .4 \\
\hline Stubioral & 123.4 & $18,100.5$ & 14.5 & $18,238.3$ \\
\hline $25 \%$ conlingency & 30.8 & 4.525 .1 & 3.6 & 4.559 .6 \\
\hline Totals & 154.2 & $22,625.6$ & 18.1 & $22,797,9$ \\
\hline
\end{tabular}

(a) Costs are in January 1998 dollars. Number of figures shown is for computational accuracy ouly and does not inmply that kevel of precision.

Approximately $91 \%$ of the total cost of the removal option is waste menagement costs (\$16.6 million). Waste managemem costs could be reduced by about $\$ 4.0$ million if the contartinated matertal was transponted to the disposal site in plastic-lined 10-m²-eapacity dump trucks instead of being packaged in $\left(2.72-\mathrm{m}^{3}\right)$ B-25 melal boxes.

\subsection{References}

1. E. S. Murphy. 1981. Technology, Safety, and Costs of Decommissioning Reference Non-Fuel-Cyde Nuclear Facilities. NUREGRR-1754, U.S. Nuclear Regulatory Carmutisșion Report by Pacific Northwest Laboratory, Riciliand, Washington. 


\section{Discussion of Results}

The conclusions reached in this report we:

(I) Decommissioning costs have continued to incresse since pubtication of References 1 and 2, duc primarily to rapidly escaleting costs for disposal of radiosctive wastes generated during decocmmissioning operations at the availabie LIW disposal siles.

(2) Rapidly tealating fees for disposal of LLW provide a significamt tincentive for NRC licensees to effectively manage ILW geperation, treaiment, and disposal from D \& D activities.

(3) Decommisstaning costs have increased on the ander of $34 \%$ to 66 titce the issuance of the Funal Decommissioning Rule in 1988.

Each of these conclusions is discussed below.

\subsection{Decommissioning Costs}

Cests are estimated for the decomissianing of facility components (boods, glove boxes, workbenches, ductwork. building surfaces, etc.) by the DECON options of (1) supercompaction and (2) supercompaction and inciperafion. Cost estimates for individual components are then used as bases for estimating the costs of decomonissionint several refereace laboratertes (described in Chapter 7 of Reference 2).

The costs of deconmissioning facility compontents arte generally estimated to be in the rapge of $\$ 140$ 10 $\$ 27,000$. depending on the cornponent, type and amourt of radioactive contamination, the DECON option chosen, and the quantity of adioutive waske genterated from decommis. sioning operations. Estrinated costs for decommissioning the reference baboratories range from aboux \$129,000 to $\$ 237,000$. Costs of decommtssioning laboratory facilities depend on streval factors. including:

- the size of the labaratory

- Laboratory destion arkd construction
- the type and amount of radioactive contarnination

- the DECON option used

- operaing practices during the lifelime of the facility

- The quantily of radioactive wask generated from decomuissioning operations

- the extent to which radioactive waste volume reduction is used.

On the basis of estimaled decommissioning costs for facility components, decommissioning a small room containing ore or two modecately conlaminaled fume hoods is estimated to cost about $\$ 25,000$. The cost of decommdssioning an entire industrial plant or research facility containing several laboratorles used to prepare and/or use rediochemicals and radioactive sources could cost several million dollars (refer to Section 3.1).

Costs estimates are made tor decomutissionting three reference sites. Costs are estimated to range from about $\$ 130,0$ to for the removal of a conbaminated arain line to $\mathbf{S 2 3}$ million for the removal of a tailings pilefevaporation pond. Costs for the latter site depend to a significaril exient on the quantiay of contaninated soil thax needs to be remowed for disposal at an authorized disposal site.

\subsection{Waste Generation, Treatment, and Disposal Management}

Since 1988, L LW disposal costs have escalinted by approx:mately a factor of 3.5 Jor the U.S. Frology site in Washington and by 2 factor of 10 for the Chem-Nuclear site in South Carolina. Thus, effective management of UW gencration during D \& $D$ operalions and its subsequent treatment and disposal can sigaificantly redoce the total cost of decommissionine of nuckar facilities. The greatest potential for miniatzing LLW management costs is with minimizing its gencration to begin with. New 
Lechnologites are actbvely under development to minimize, if not eliminate altogether, the generulion of secondary $L L W$ frum decontaninalion operations. The $\mathrm{CO}_{2}$ peltei decontarsingtion process and the supersonic gas-liquid cleaning technologies discussed in Sextion 4 provide examples of such technologies.

Using volumk-reduction lechnology during decomitrssioning operations to reduce the quanliny of radioactive waste that needs to be disposed of can significanily reduce disposal coss5. The average waste management cost (without coutıngency) for the six facilities when super. compaction is used is aboul \$45,000, without supercompaction this cost increases by 111 \% to $\$ 95,000$. No savings from volume reduction were possible dunng decomrissioning of the reference siles bexause very litle. If any, of the ratioactive waste was volume-reducibie.

While incintration of radioactıve waste can significantly reduce the volume of waste that needs to be disposed of, it is also very expensive. In fact, it may cost more to incinerate the waste than to just dispose of it. However, incinera. tion cosis are strongly relaled to economies at-scale, which is one reasion why radioactive wasle incineration facilities have only beep des/gned and built to incinerale a select few waste types (i.e., radioactively contarunated waste oil from nuclear power plants).

Whiłe supercompaction and incineration can signiftcantly reduce waste volumes, both are applicable only to dryactive waste. A significant cost from decommissioning operations is from disposal of solıdified liquid wrstes, for the reference facilaties, and contamusted soll, for the relerence sīles. Making an additional efiort in planning decommissioning operations and selecung decommisswoning technology that muimizes ths non-volumereducible wasie could resuf! in signifieant savings in disposal costs. Also, a new LLW/mixed waste disposal sice in Utah (operaled by Envirocare of Utah. Inc.) offers disposol services for wey low-lavel radioactive and mixed wastes at costs significantly below the current regional commercial LLW disposal sıles at Rrchland, Washíngton. and Barnwel1, South Carolina.

\subsection{Escalation Since the Final Decommissioning Rule}

The present study indicates that decoumssioning costs for non-ftrel-cycle nuciear facilities, such as thase described it Section 2.6, are in the tange of $\$ 130,000$ to $\$ 205,000$, assuming aggressıve LLW volume reduction, and $\$ 150,000$ $10 \$ 270,000$, assuming minimal LLW wolume reduction. (See columns 4 and S, respectivety, in Tabie 8.1.) The decomurissioning fund certificalion amounts established in the 1988 Final Decommissioning Rule were derived by escalating the costs as estimited in the original study (Reference 2) to 1986 dollars, which wete in the range of $\$ 100,000$ to $\$ 140,000$, (See colums ( and 2 in Table 8.1.) These results suggest that decommistioning costs since the 1988 Decommissioning Rule have increased by $34 \%$ (assurnung aggressive volume reduction) to $66 \%$ (assuming minimal volume reducuon).

Table 8.1 Comparton of decommisstoning costs

\begin{tabular}{|c|c|c|c|c|}
\hline $\begin{array}{l}\text { Refertace } \\
\text { Laboritory }\end{array}$ & $\begin{array}{l}\text { NUREG/Ck: } \\
1754 \text { (1978\$ } \\
00(0)\end{array}$ & $\begin{array}{l}\text { NUREGICR- } \\
\text { 1754 } \\
\text { (escelated to } \\
1986 \$ 000 \text { ) }\end{array}$ & $\begin{array}{c}\text { Presedt report, } \\
\text { Section 26 } \\
\text { (1998 } 5 \text { (0D0) }\end{array}$ & $\begin{array}{c}\text { Present report } \\
\text { (wfo sopercompaction, } \\
\text { 1998\$ (100) }\end{array}$ \\
\hline${ }^{3} \mathrm{H}$ & 67 & {$[40]$} & 174 & 223 \\
\hline${ }^{14} \mathrm{C}$ & 59 & 119 & 166 & 219 \\
\hline 121 & 53 & [0] & 129 & 150 \\
\hline${ }^{131} \mathrm{Cs}$ & 53 & 99 & 155 & 170 \\
\hline${ }^{2+}$ Asm & 74 & $14 !$ & $147^{(n)}$ & $172^{(\omega)}$ \\
\hline Usses & 63 & 126 & 205 & 269 \\
\hline
\end{tabular}

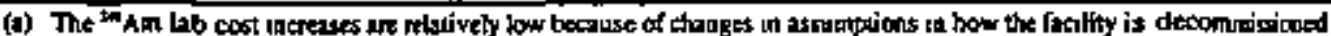

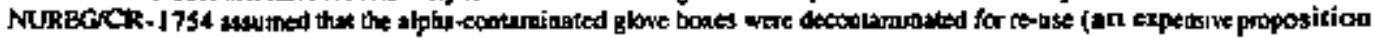

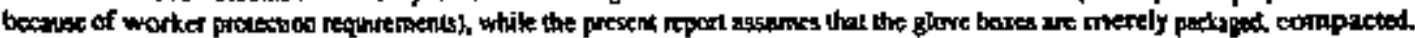
and duptosed of os $\amalg W$. 


\subsection{References}

t. S. M. Short, 1989. Technology, Safeny and Cosss of Decommisstontug Reference Non-Fuel-Cycle Nuclear Facitities. NUREG/CR-17S4, Addendum 1, U.S. Nuclear Regulatory Commission Report by Pacific Northwest Laboralory, Richland, Washington.
2. E.S. Mutphy. 1981. Techtmolozy, Safety, and Costs of Decommissfoning Reference Non-Fuet-Cycle Nuclear Facitities. NUREGCR-1754, U.S. Nuxlear Regultitory Commission Report by Pacific Nonthwest Laboratary, Richland, Washington. 
Appendix A

\section{Cost Estimating Bases}




\section{Appendix A}

\section{Cost Estimating Bases}

The cosi estimate information developed th this reevaluation study is based on unil cost data presented in this apperdix. Calegories for which basic unit cost estimaiting data are given include: salaries, waste packaging, transpor, waste disposal, special equiponent and services, and supplies. The following major bases and assumptions apply to 1 he decommissioning cost estimates in this neevaluation of the reference non-fuel-cycle facilities and their components.

- The estimated cast data presented in this report are carly-1998 costs.

- A contingency of $25 \%$ is added to all estimated costs.

- Decommissioning involves Jemoval of facility components or decontarmination of selected components of the facility orly to the exlent that the NRC license may be termintted and the remaining facility and stte may be released for unrestricted use. This study, unlike the original study described in References 1 and 2, does not censider the option of complete decontamination of the facility components bejore disposal. Extensive decontamination of the small number of small components in facilities such as these is expensive, and does not wartant the extra clean-op of the cornponents needed for unutstricted use. Rather, minimal decontamimation is carried oal in this stuxly, followed by cutting and packagjog and volume reduction of the radicsctively-conaminated malerial for disposal at a licensed LLW burial gुoverid.

- The study does not addess the removal of bulk, packared, inventory quantities of radionuclides from the facilities and their uhimate disposition. Rempual aff-site of these quantities is assumed to hawe been completed before physical decocrutistioning begints.

- The cost estimates in this recraination study. Just as it References 1 and 2, take into consideration only those decommis. sioning costs that affecl public health and safety (i.e., costs to reduce the residual radioactivity in a facility to a level that permits the facility to be relessed for unrestricted use und the NRC license to be teminated). IIence, the cost estingates in this tudy do not include such items as the cost to remove clean maiterials and equipment nor to restort the land to a "green fleld," which would requife sdditional demplition and sile restoration activilies in some cases. Although the afditional costs for site restoration may be needed from the viewpolnt of public retations or site resale value, they are not related to hadth and safely, and therefore were considered to be oulside of NRC's area of responsibiliry.

- An altemste cost estingte is developed for the decommissioning of the triling pile/evaporation pomd site whicb ussumps the rejatively low activity comtaninated material can be slabilized on-sile foliowed by annual surveillance and maintenance of the site. This would be considered a restricted land use stituation without license termination, but woold assure minirnol risk to public healih and safely.

- To develop the cost estimates for a facility, the "butilding block" tectanique is used. First the cost of decorminissioning each costiposent of the facilty is estmated. These costs are then added together to detemine the total cost for decommissioning the entire facitity. This approsch allows for zeneration of simple algorihms for decommissioning other facilities thet are not the sarte as the reference facilities studied bere. 
- The estrmaled cosls for decommussioning the reference facslities in this study include the costs tor slaff tabor. equipment, suppless, and waste management (treatmert or volume reduclion, packsiging, transportalion, and disposel of radioactive waste).

- The study assumes that all the applicable radioactive waste materials that resull lrom the decommissoning are sreated by volume reduction, if praclical, (i.e., supereompection or incineration by off-site contractors) before final packaging and disposal. Reference 2 (tn 1988 dollars) showed a signifkent financial incentive for such action, as controlled by the high cosls of radioaclive waste dspossi. Since that time, low-level radioative wasle disposal cosis have contiaued to increase dramatically. Thus, decommissioning withou volume reduction would only be done at a significant cos! penalty and would nol likely be done in the future. In this study, the removal of soils or tailings characterized by low concentrations of radioactive matertal assumes no volume reduclion.

- Some facilities of the types covered in this report may have sinks unlo which kow acuvity liquids are discharged to an outsida, buried holdup tank. The costs for decommssioning the contaminated outside-buried pipe and holdup tank are not inchuded in the estimated costs for tach facility, bul are esimated separately. Thus, if a specifie facility has such outside-contaminated fealutes, the estimated costs for decommissioning these features must be addsd to the costs for decommissioning the facitity. It is assumed in this study that an outside contractor is used for this part of the decomrissioning

- The cost estimate is not site-specific tor the facilities. Generic, natıonwide values are used for unt cosis tor all categories unless otherwise identified.

- Labor rates and overheads for ownerfopetator and contractor personnel are shown in Table A.1. Except where noted in this table, labor males and overhead costs are taken from Reference 3. Overhead fales applied to drect staff labor are expected to be signifteanly higher for subcontracting organizations than for the facility operator because of the larger

Table A,1 Labor costs for decammissloplag

\begin{tabular}{|c|c|c|c|c|}
\hline Position & $\begin{array}{l}\text { Anuual } \\
\text { salury }\end{array}$ & $\begin{array}{c}\text { Overhead } \\
(\%)\end{array}$ & $\begin{array}{c}\text { Annuol salary/ } \\
\text { w overtiew }\end{array}$ & $\begin{array}{l}\text { Hourly rate/ } \\
\text { w oyerhead }\end{array}$ \\
\hline Supervisor & 61,310 & $70.0^{4-1}$ & 103,887 & 56.46 \\
\hline Fortman & 55,545 & 60.0 & 88,872 & 48.30 \\
\hline Croftsmin & 54,495 & 60.0 & 87,192 & 47,39 \\
\hline Techunician & 52,500 & 53.7 & 80,693 & 43.85 \\
\hline H. P. Tech & 51,030 & 53.7 & 78,433 & 42.63 \\
\hline Clerk & 12,860 & 61.2 & 20,730 & 11.27 \\
\hline $\begin{array}{l}\text { Equipment } \\
\text { Operator }\end{array}$ & 53,970 & 141.5 & 130,338 & 70.84 \\
\hline Laborer ${ }^{(t)}$ & 45,580 & $\$ 41.5$ & 100,416 & 54.57 \\
\hline Tnxk Priver & 43,470 & $\$ 41.5$ & 104,980 & 5705 \\
\hline
\end{tabular}

(a) Estimated.

(b) Subeontractor Workers. 
ratio of supervisory and support personnel to direct labor that usually exists in subcontracting organizations. Having personnel in the field rather than in the home office afso increases the overhead costs, because of travel and living expenses for some of the personnel. In view of these fattors, an overtead rate on direct staff labor of $110 \%$. plus $15 \%$ profil on labor and its pverheads, is assumed to be applicable to all subcoptractor workers in this revaluation study.

- Estimated time requiremenes to efficiently carry out a decomomissioning lask for a work crew are increased by $505 \%$ to allow for work ineffictencies, unjoreseen situations, preparation and set-up times, and rest periods.

- All decommissioning activities within a facility, starting with the predecomunissioning work (e.g- planning, activity specificstions and procederes), and continuing through the final license termination, are assumed to be cartied out by the facility staff, extept where otherwise identified (e.g-s supercompacting, incineration, waste transportation, waste disposal). Decomntissioning of outside facilities (e.g.+ sink drain line and buried hold up (ank) and she land where necessary, and waste wolume reduction, are assumed to be performed by a contractior hired by the lacility operator.

- In most cases, a single work crew is used, and one component at a time is decommissioned. For decommissionting a given component, a work crew is assubned to work 8 hours/day and consists of a foreman and two textrnicians, assisted by a half-ime health physicis monitor. In some cases (identified where used), craftsmen (e.g., tectricians, pipe fitters, etc.) are added to perform spectific lasks such as discannecting services and preparing a component for packaging. $\mathbf{A}$ supervisor is «ssumed to be assigned to the decommissioning slaff on a half-time basis for the total facility. He performs overview functions, such as Q.A., doctmentation, and management of the decomunissioning. A clesk is used for 15 to 20 person-days during the total decommissioning activities, including planning, and fonal Jicense termination.

- Labor, materials, and equipment costs for conventional cleaning and construction activities were taken from References 3 and 4.

- All waste is assumed to be placed in 208-liter drums or B-25 metal containers. No other containers are used. After compacting at the facility, void spece is assumed to be $30 \%$. Supercompaction is assumed to reduce the post-cormpacted waste by an additional factor of three. In this study, the cost for supercompaction is assumed to be $\$ 100$ per 208 . jiter dram' Incineration is assamed ta reduce the post-compacted incinerable waste volume by a factor of 10 . The

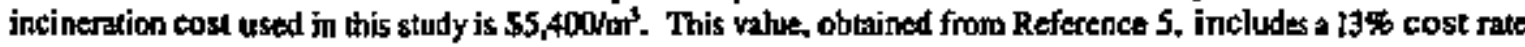
increase (Reference 6) to convert to 1998 dollers and a $25 \%$ charge for packaging, labeling, and preparation of shipping documents.

- Aqueous liquid wastes, such as aquecus cteaning solulions, are assumed to be golidified with Aquaset", or Other equivalent material, in 208-1iter waste drums.

- Miscellaneous traterial costs and task completion times assumed in this sludy are presented in Table A.3.

- Costs relevant to the sile decomrissioning antlyses (Chapter 7) are presented in Tables A.3 and A.4.

- Transportation cost estimates for radicactive wasles are taken frotn Reference 7. Transportation of $L W$ is by singlepurpose tratox-truck that can hold one hendred-twenty 208-liter drums, ox 40 drums of supercompacted wastes (based an weight restrictions). Transportation costs of wastes from individual components are estimaled by assuming the

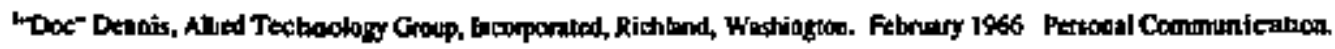


Table A.2 Miscellancous costs, weights, and rates

\begin{tabular}{|c|c|}
\hline $\begin{array}{l}\text { Equiprnent and material cosis (\$) } \\
\text { 208-liter drum } \\
\text { B-25 metal box } \\
\text { Commercial vacuum } \\
\text { Waste compacter }\end{array}$ & $\begin{array}{r}50 \\
645 \\
2,900 \\
16,400\end{array}$ \\
\hline $\begin{array}{l}\text { Weights } \\
\text { Empty 2008-liter drum (kg) } \\
\text { Empty B-25 metal box (kg) }\end{array}$ & $\begin{array}{r}21 \\
270\end{array}$ \\
\hline $\begin{array}{l}\text { Surface rates }\left(m^{2} / h\right) \\
\text { Dry vacuurn } \\
\text { Dry or wet wiping } \\
\text { Painting } \\
\text { Concrete scabbling rate } \\
\text { Asphull tile removal } \\
\text { Suspended ceilıng removal }\end{array}$ & $\begin{array}{l}60 \\
30 \\
30 \\
10 \\
11 \\
14\end{array}$ \\
\hline Cutting rate (steel, plastic, or metal, $\mathrm{m} / \mathrm{hr}$ ) & 60 \\
\hline
\end{tabular}

Table A.3 Charges for contractor equlpment far decommlsstoning of sites that

\begin{tabular}{|c|c|c|}
\hline \multirow[b]{2}{*}{ Equjpment Item } & \multicolumn{2}{|c|}{ Estimated rental tee } \\
\hline & (\$week) & (Nmonth) \\
\hline Tractor, farm lype & 1,110 & 3,325 \\
\hline Grader, self-propelled & 1,600 & 4,800 \\
\hline Roller, sheepsfoot, self-propelled & 1.920 & 5,750 \\
\hline Front loader (2-m³ -capacity) & 1,410 & 4,225 \\
\hline Backhoe (2-m -capacity) & 6,300 & 18,900 \\
\hline Bulldozer & 1,810 & 5.425 \\
\hline Soil stabilizer, self-propelled & 4.200 & 12.600 \\
\hline Scraper-hauler (20-m3-capacity) & 6.470 & 19,400 \\
\hline Dump truck (10-min-capacily) & 1,360 & 4,075 \\
\hline Lift truck (l0-Mg-sapacily) & 770 & 2,300 \\
\hline Crane, boom-type (10-Mg-capacily) & 1.725 & 5,175 \\
\hline Light-duty dnlling ng & 6,535 & 19.600 \\
\hline Disc-hartow, trackor-drawn & 400 & 1,200 \\
\hline Seeder, tractor-driwn & 480 & 1,440 \\
\hline
\end{tabular}

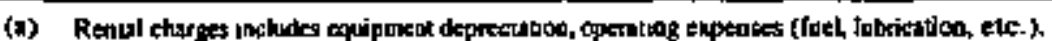

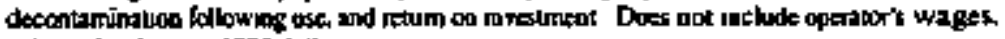

(b) Adjusted to jabuary 1998 dollers 
Table A.4 Upit costs of supplies, materiak, and soll analyses for decongmissioning of sites

\begin{tabular}{|c|c|c|}
\hline Item & Untiss & $\begin{array}{c}\text { Estimated } \\
\text { unit cost }\end{array}$ \\
\hline Backfill (topsoit) & $\mathbf{m}^{3}$ & $18^{(b)}$ \\
\hline Backfill (common boxtow) & $\mathbf{m}^{3}$ & $4.6^{\mathrm{m}}$ \\
\hline Gravel (graded) & $m^{3}$ & $5.4^{b+b}$ \\
\hline Asphalt emulsion & $\mathrm{mi}^{3}$ & 70 \\
\hline Seed & kg & 4.5 \\
\hline Fertilizer & $\mathbf{k g}$ & 0.34 \\
\hline Straw & basle & 2.3 \\
\hline Anti-contanination cloching & $\begin{array}{l}\text { per person } \\
\text { per week }\end{array}$ & 100 \\
\hline PVC pipe (0.15-m-diameter) & $m$ & 20 \\
\hline Chatn-link fencing (1.8-m-wide) & $\mathbf{m}$ & 28 \\
\hline Soil analysis & each & 200 \\
\hline Cutie pie delector & each & 1,200 \\
\hline G-M probe & each & 240 \\
\hline $\begin{array}{l}\text { Gamina Seintillalion probe } \\
\text { (3" } \times 3^{\prime \prime} \text { crystal) }\end{array}$ & each & 1,6680 \\
\hline Ratemeter (log-fin.) & each & 1,440 \\
\hline $\begin{array}{l}\text { Phoswhich delector ( } 5 \text { " } \\
\text { diampeter) }\end{array}$ & each & 10,800 \\
\hline
\end{tabular}

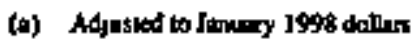

(b) Cost inowa dos Dod inclose delukery to site

wastes to occupy the respective fraction of a sruckload of wastes from that component. The waste volnore reduction facility (superconpaction or incineration) is assumed to be $350 \mathrm{kng}$ from the facility: the L.LW disposal facility is assumed to be on additional $800 \mathrm{kn}$ from the waste volutre reduction facility. Wastes that are not adoenable to volume reduction are shipped directly to the LWW disposal facility, assumed to be 800 km away.

- All radjosctive wastes resuling from deconunissioning, primarily low-level radikactive wastes or low-acti vity wasles, are assumed to be shipped for disposal to * lictensed disposal site. The two major sites are the U.S. Erology Facility near Richland, Washington, and the Chemr-Nutlear Facility near Bamwell, South Carolina. An additional disposal facility is availzble for low-activity radioactive wastos (LARW), particularly radioactively contaminaled soils, ax the Enviracare Faeility near Cive, Utah. Radioactive wastes from the reference contaminated ground stufface sile and the tailings pilefevaporation pond site are assumed to be disposed of at the Envirocare Facility. This study uses the burial rale schedule provided by U.S. Ecology. Reterence 8 , for LLW, exclusive of soils. 
- Cerian components in some of the non-fuel-eycle facility operations areas are not used for radjoactive materials or for uncontarninated sealed radioactive malertals. These components inciude cabinets, refrigerators, freezers, and washing machines. It is assumed fn this stucty, that unjess othenwise noted, these components are monitored to ensure they are uncontarninated, then removed ond salvaged by the owner as non-fadioactive materials.

- The study does nor address the renoval or disposal of mixed or hazardous wastes fram the faciliny. The costs for such activities are assumed to be operational costs covered by and active Resource Conservation and Recovery (RCRA) perrnit for the facility. However, the study does include consideration of the constraints that the presence of mixed wastes on-site may impose on decommissoming altematuves and on schedules.

- For purposes of this study, the ultimate cost of disposal of maxed wastes (either liquid or solid) expected to be present on the sile of the reference facility at sinal shutdown are considered to be operational costs, since the majorily of such wasles are postulated to be generated during operation of the plant. It should be realized. however, that regardless of when any solid mixed LLW was generaled, commencial treatment, storage, and dispasal services for the wasto do nol currently exist for most of the waste. Based on the discussion above, il is assumed further that implementation of waste miniznization techniques used during the operaling years of the facility will also be used during decomrissiontng. Therefore, essentally no solid muxed LL.W is assamed to be generaled during decommissioning of the reference facilities in this report.

- Salvage values of recovered, potentially reusabte matertais are not considered.

- Property taxes are nor considered.

\section{A.1 References}

1. E. S. Murphy. 1981. Technology, Safety and Costs of Decommissianing Reference Non-Fuel-Cydie Nuclear Facilities. NUREG/CR+1754. U.S. Nuclear Reguiatory Cornnission Repost by Pacific Northwest Laboratory, Richland. Washington.

2. S. M. Shert. 1989. Technolagy, Safety and Costs of Decommissionang Reference Non-Fuel-Cycle Naclear Facilities. NUREG/CR-1754, Addendum 1. U.S. Nuclear Regulatory Commission Repont by Pacilic Northwest Laboratory. Richland, Washington.

3. Building Contiruction Cost Data-1996. R. S. Means Co., Ine., Kingston, Massachuse1ts, 1996.

4. Means Estimasing Handbook. R. S. Means Co.t Inc., Kingston. Massachusetts, 1990.

S. "Schedule of Rates for the Penod Jane J, I992 through May 31, 1993." Scientific Ecology Gromp, Oak Ridge. Tennessee, 1992.

6. Handy-Whisaan Index of Public Vtility Cosis, Bulletin No. [42, Section E-6. Whitman, Requardt and Asscciates, I995.

7. TSMT 4007-C. Secured Tronspenation Senvices, Radioactove Materials Tanjf. Tri-State Motor Trassit Co., Joplin, Missouri, December 1995.

8. U.S. Ecology. Inc,, Washington Nuclear Center, Radioactive Waste Disposal Schedule A. January 1996. 
Appendix B

Process Times Estimating Methodology 


\section{Appendix B}

\section{Process Times Estimating Methodology}

The decommissioning of laboralory components involves several steps: partial surface decontamination and/or fixing of loose surface contaminants, component segmealation, packagiag, and loadout. This appendix develops lhe algorithms used to cakculate the time required to perfom each of these sleps. The Jabor cosl associaled with each step is then easily tound by multiplying the bourly lakor eost af the crew doing the wodk by the time required to pertiom the stop.

\section{B.1 Surface Decontamination and Removal Times}

As discussed in Appendix D, most component surfaces are partially deconlaminaled and/or painted to reduce or fix surface contamination before the componenls are cut up for disposal. The time required for perfocming a surface decontanuation procedure is found by dividing the total surface area by the rale (in $\mathrm{m}^{2} \mathrm{hr}$ ) eppropritate for that procedure. Times tequired for removing layers of materials are calculated the same way. Surface rates for different procedures are given in Appendix A, Table A.2.

Examples: Using values from Table A.2, it is found that a $60 \mathrm{~m}^{2}$ wall requites $60 / 60=1$ hour to dry vacuum and $6030=2$ hours to paint. Removing asphalt tile from a $60-\mathrm{m}^{2}$ toox sequites $60 \mathrm{H}^{\prime} \mathrm{I}=5.5$ hours.

\section{B.2 Cutting Times}

In this study it is assumed that components wilh large surface areas (eg. glove boxes, firne hoods, cabinets, workbenches, refrigerators, freezers) witl be cut inlo flat, square pieces small enotght $\left(0.16 \mathrm{~m}^{2}\right)$ to fit isio a drum. To determine the number of cuts required. suppose that a typical ftat surface of area $A$ measuses $L$ by $W$ and that it is desined to cut this inio trtall square pieces measuring b by $b$. Then there will be ina(W/b) cuts of length $L$ and int(L/b) cuts of (tength W, whexe int $(x)$ is the greatest integer in $x$. (For example, inl(3.6) $=3$.) The total length of the cuts is then $L x$ int $(W / b)+W x$ im( $(\omega)$ ). If W and $L$ are relatively large, then int(W/ $)$ and int(L/) can be approximated by W/b and $1 / b$, without introducing too great an entor. With this approximation, the tetal leagh of the cuts is LW/b $+W L / b=2 \mathrm{~A} / \mathrm{b}$. Dividing Ihis by the culting rite, $r$, gives the culting timst $1=2 \mathrm{~A} /(\mathbf{r b})$.

Exampies: A typical fume hood has a totil surface area of about $13 \mathrm{~m}^{2}$. If the hood is to be cril toto squares of about $0.16 \mathrm{~m}^{2}$, so that the pieces will stack neatly inside a drum, the total cutting length is $2 \times 1304$, or abuut 65 dtelters. Dividing this by the assumed cutting rate of $60 \mathrm{~m} / \mathrm{hr}$ (Appendix A) gives a curting time of about one hour. For 2 refrigeralor (assumed to be essentially holkw) with a totsl surface area for the six sides of about 4.5 mi?, the total cuting length is $2 \times 45 / 0.4=22$ meters. This gives a cutting time of $22 / 60=0.4$ hour. 


\section{B.3 Packaging and Loadout Times}

The time required to colfect, bog, and fill a drum with waste is based on limes eslimaled in Reference 1 for hazardous material abatement. Reference I estimates that 0 og hours would be required to collect, bag. and conlanenze one drum of waste, assuming that three bags of compacted waste will fill a drum. Doubling this tisne to aceount for an-5ule cornpactung gives the vatue of 0.18 hoursidrum used in this report. Liquid wastes are processed in the drum by the addition of a solidifing agent (Aquase* or its equivalent) It is assumed thel the tume required for the addition and mixing of this agenl in the drim is 0.25 hours. Once a drum is packaged it is moved to the loadout area. A loadout lime of 0083 hours/drum is assumed for this study.

\section{B.4 References}

1. "Bujlding Construction Cost Data 1996." Robert Srow Means Compsny, Inc., Kingston, Massachuseits. 


\section{Appendix C}

Details of Decommissioning Facility Components 


\section{Appendix C}

\section{Details of Decommissioning Facility Components}

This appendix provides cast estimates for the DECON of typical facility components. DECON consists of disnssembly, packaging and on-site compaction of the componedts, followed by futher volume reduction, ejther 1) supercompaction at a centralized facility or 2) supercompaction and incineration at a centralized facilíly. Following volume reduction, the components are buried al a shallow-land burial ground. Descriptions of the facilities and facility componenls are given in Appendix $A$ of Reference 1 and in Appendix $D$ of this report. The key sssumptions and bases used for estimating manpower requirements and costs are given in Appendix A. The following steps are assumed in the DECON of facility components:

- remove equipment and material and perform initial radiation survey

- remove bopse contamination and fix residual contaminatian

- disconnecl service tines as reçuired

- Calt component into pieces to elficiently fill the disposal conlainers (20,-liter drums)

- package picoes to plastic and place in drums

- shjp drums to central facility for waste reduction treatment: supercompaction (Option 1) or supextampaction and incineration (Option 2)

- ship trealed waste to low-lewel waste (L,W) brial grounds.

A work crew consisting of a foremant and two technicians is assumed to perform the DECON work. When disconnecting or nemoving components, this trew is assisted as necessary by an electriciar or craftsman. Complete descriptions of the DECON operations performed on each facility component are contained is Appendix $\mathbf{D}$.

\section{C.1 Fume Hoods}

Estimated costs for decommissionine a radiological fume bood at each faclily are shown in Table C.J.a for Option 1 and in Table C.1b for Option 2. Total costs include manpowter, equipment and suppties, and waste manegernent costs. Waste managerment costs toclucle the cost of disposal of the hood only. Roughing and HEPA filıers are considered separate components and are discussed in Section C.9. 
Appendix C

Table C.1+a Cast (\$ thousands) for DECON of a fume hood at each of the indkated facilitiessupercompaction optinn

\begin{tabular}{|c|c|c|c|c|c|c|}
\hline Cost item & $\begin{array}{l}\text { 'yl } \\
\text { lab }\end{array}$ & $\begin{array}{l}{ }^{40} \mathrm{C} \\
\text { tab }\end{array}$ & $\begin{array}{l}1251 \\
19 b\end{array}$ & $\begin{array}{c}\text { 'IT Cs } \\
\text { lab }\end{array}$ & $\begin{array}{c}\mathrm{Sum}_{\mathrm{Am}} \\
\mathrm{lab}\end{array}$ & $\begin{array}{l}\text { User } \\
\text { Jab }\end{array}$ \\
\hline Manpower & 3.13 & 326 & 3.37 & 3.73 & 334 & 3.17 \\
\hline Equipment \& supples & 1.10 & 1.23 & 1.48 & t.69 & 125 & 1.00 \\
\hline \multicolumn{7}{|l|}{ Waste management } \\
\hline Packaging & 0.13 & 0.13 & 008 & 0.13 & 0.13 & 0.13 \\
\hline Processing (supercompaction) & 0.27 & 028 & 0.17 & 0.28 & 028 & 0.29 \\
\hline Processing (incineraben) & .. & - & $\cdots$ & - & -. & - \\
\hline Transportation & 004 & 0.04 & 0.02 & 0.04 & 004 & 004 \\
\hline Disposal & 136 & $\$ .41$ & Q87 & 140 & $\underline{1.39}$ & 1.44 \\
\hline Waste managernent subtotals & $\mathrm{J} .80$ & 1.87 & 1.14 & 1.85 & 184 & 1.90 \\
\hline Total & 6.03 & 636 & 5.99 & 7.27 & 643 & 6.07 \\
\hline 25\% Contingency & $\underline{1.51}$ & $\mathbf{L 5 9}$ & 1,50 & 1.82 & $\underline{161}$ & $\underline{152}$ \\
\hline Totals & 7.54 & 7.95 & 749 & 9.09 & 8.03 & 7.59 \\
\hline
\end{tabular}

Table C.1.b Cost (\$ thousands) for DECON of a fume hood at each of the indlcated facilitiessupercompaction winclneration

\begin{tabular}{|c|c|c|c|c|c|c|}
\hline Cost item & $\begin{array}{l}\text { 'H } \\
\text { lab } \\
\end{array}$ & $\begin{array}{l}{ }^{\mathrm{s}} \mathrm{C} \\
\mathrm{Iab}\end{array}$ & $\begin{array}{l}\text { 12:1 } \\
\text { lab }\end{array}$ & $\begin{array}{l}{ }^{m} \mathrm{Cs} \\
\text { lab }\end{array}$ & $\begin{array}{c}24 \mathrm{Am} \\
\text { lab }\end{array}$ & $\begin{array}{l}\text { User } \\
\text { lob }\end{array}$ \\
\hline Manpower & 3.13 & 3.26 & 337 & 3.73 & 3.34 & 3.17 \\
\hline Equipment \& supplies & 1.10 & 1.23 & 1.48 & 1.69 & 1.25 & 1.00 \\
\hline \multicolumn{7}{|l|}{ Wasle mangement } \\
\hline Packaging & 0.13 & 0.13 & 0.08 & 0.13 & 0.13 & 0.13 \\
\hline Processing (supercompaction) & 0.22 & 0.23 & 0.5 & 023 & 0.23 & 0.24 \\
\hline Processing (tincineration) & oso & 0.51 & 0.26 & 0.51 & 0.49 & $0.5 t$ \\
\hline Transportation & 0.03 & 004 & 0.02 & 0.04 & 004 & 004 \\
\hline Disposal & 119 & 124 & $\underline{0.78}$ & 1.23 & $\$ 22$ & 1.27 \\
\hline Waste management sublotals & 2.07 & 2.15 & 1.28 & 2.13 & 211 & 2.18 \\
\hline Total & 6.3I & 6.64 & 6.14 & 7.55 & 6.70 & 6.35 \\
\hline 25\% Contingency & 1.58 & 166 & 1.53 & 1.89 & 167 & L.59 \\
\hline Tolals & 7.88 & 8.30 & 7.67 & 9.44 & 8.37 & 7.94 \\
\hline
\end{tabular}




\section{C.2 Glove Boxes}

Estimaled costs for decommissioning a glove box at each facility are shown in Table C.2.a for Option 1 and in Table C.2.b for Option 2. Toeal costs inciude manpower, equipment and supplies, and waste managerrent costs. Waste management costs include the cosi of disposal of the glove box only. Roughing and HEPA filters are considered separate components and are discussed in Section C.9.

\section{C.3 Small Hot Cell}

Estimated costs for decommissibaning a small hot cell are shown in Table C.3.a for Oplion I and in Table C.3.b for Oplion 2. The ondy teference laboratory that contains a hot cell is the laboralory for the manufacture of ${ }^{157} \mathrm{Cs}$ sealed sources described in Section 7.1.4 af Reference 1. Total costs include manpowet, equipmenl and supplies, and waste management costs. For both Options I and 2, hat cell waste (peitnarily lead bricks) is tent directly to a nixed waste disposal facility; no coupaction or intineration is posiulated.

Table C.2.a Cost (\$ thousands) for DECON of a glove box at each of the findileated facilitiessupercompaction optlon

\begin{tabular}{|c|c|c|c|c|c|c|}
\hline Cost ilem & $\begin{array}{l}\text { यh } \\
\text { lob }\end{array}$ & $\begin{array}{l}\text { "lc } \\
\text { lab }\end{array}$ & $\begin{array}{l}1251 \\
\text { lob }\end{array}$ & $\begin{array}{l}{ }^{157} \mathrm{Cs} \\
10 \mathrm{~b}\end{array}$ & $\begin{array}{c}\mathbf{m}_{\text {Am }} \\
\text { lab }\end{array}$ & $\begin{array}{l}\text { User } \\
\text { Iab }\end{array}$ \\
\hline Manpower & 0.97 & 1.02 & 1.04 & - & 2.71 & 1.10 \\
\hline Equipmest \& supplies & 0.34 & 0.38 & 0.46 & - & 1.02 & D.35 \\
\hline \multicolumn{7}{|l|}{ Waste makagement } \\
\hline Packoging & 0.09 & 0.09 & 0.12 & - & 0.11 & 0.10 \\
\hline Processing (supercormpsction) & 0.20 & 0.20 & 0.25 & - & D. 24 & 0.21 \\
\hline Processing (incineration) & $\cdots$ & - & - & $\leftrightarrow$ & - & - \\
\hline Tremsportetion & 0.03 & 0.63 & 0.04 & - & 0.03 & 0.03 \\
\hline Disposal & 1.09 & 103 & 1,28 & $=$ & 123 & 1.04 \\
\hline Waste nranagement subtotals & 1.35 & 1.35 & 1.69 & - & 1.62 & 1.37 \\
\hline Total & 2.66 & 276 & 3.19 & - & 5.35 & 2.82 \\
\hline 25\% Contingency & 0.67 & 0.69 & 0.80 & $=$ & [134 & 0.70 \\
\hline Totals & 3.33 & 3.45 & 3.99 & - & 6.69 & 3.52 \\
\hline
\end{tabular}


Table C.2.b Cast (\$ thousands) for DECON or a glove box at each of the indicated facilitiessupercompaction w/incineration

\begin{tabular}{|c|c|c|c|c|c|c|}
\hline Cost item & $\begin{array}{l}\text { 'H } \\
\text { lab } \\
\end{array}$ & $\begin{array}{l}{ }^{14} \mathbf{C} \\
\text { lab }\end{array}$ & $\begin{array}{l}\text { lys } \\
\text { lab }\end{array}$ & $\begin{array}{c}{ }^{15} \mathrm{Cs} \\
\mathrm{lab}\end{array}$ & $\begin{array}{c}\mathrm{MAm}_{\mathrm{Am}} \\
\mathbf{k} \mathbf{k}\end{array}$ & $\begin{array}{l}\text { User } \\
\text { lab }\end{array}$ \\
\hline Manpower & 0.97 & 1.02 & 1.04 & - & 271 & 110 \\
\hline Equipment \& supplics & 034 & 038 & 0.46 & - & 102 & 0.35 \\
\hline \multicolumn{7}{|l|}{ Waste management } \\
\hline Packaging & 009 & 0.09 & 0.12 & - & 0.12 & 0.10 \\
\hline Processing (supercompaction) & 018 & 0.18 & 0.25 & -- & 0.20 & 0.18 \\
\hline Processing (incineration) & 0.24 & 0.25 & 0.03 & - & 0.42 & 0.26 \\
\hline Transportation & 0.03 & 0.03 & 0.04 & -- & 003 & 0.03 \\
\hline Disposal & 094 & ogs & $\underline{127}$ & $=$ & Lo8 & 095 \\
\hline Waste management subtotals & 148 & 1.49 & 1.71 & - & 1.85 & 1.51 \\
\hline Total & 2.80 & 289 & 320 & -- & 559 & 296 \\
\hline 25\% Contingency & $\underline{070}$ & 072 & Q.80 & 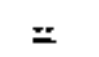 & $\underline{140}$ & 0.74 \\
\hline Totals & 3.50 & 3.62 & 4.01 & -. & 6.98 & 3.70 \\
\hline
\end{tabular}

Table C.3. Cost (\$ thoursands) for DECON of a small bat cell at the ${ }^{13} \mathrm{Cs}$ laboratorysupercompartion option

\begin{tabular}{|c|c|c|c|c|c|c|}
\hline Cost tiem & $\begin{array}{l}\text { s } \\
\text { lab }\end{array}$ & $\begin{array}{l}14 \mathrm{C} \\
\text { lab }\end{array}$ & $\begin{array}{l}12 y_{I} \\
\text { lab }\end{array}$ & $\begin{array}{l}{ }^{13 \prime} \mathrm{Cs} \\
\text { lab }\end{array}$ & $\begin{array}{c}{ }^{21} \mathrm{Am} \\
\mathrm{lab}\end{array}$ & $\begin{array}{l}\text { User } \\
\text { Lab }\end{array}$ \\
\hline Manpower & -- & -- & - & 5.13 & - & -- \\
\hline Equipment \& supplies & - & -- & - & 2.33 & - & -- \\
\hline \multicolumn{7}{|l|}{ Waste managemem } \\
\hline Packaging & - & -- & - & 0.43 & - & - \\
\hline Processing (stupercompaction) & - & - & - & 0.10 & - & - \\
\hline Processing (incineralion) & - & - & - & - & - & - \\
\hline Transportation & - & - & - & 0.09 & - & - \\
\hline Disposal & $=$ & $=$ & $=$ & 13.07 & $=$ & $=$ \\
\hline Wasle munagement subtotals & - & 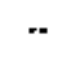 & -- & 13.69 & -- & - \\
\hline Total & - & 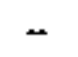 & - & 21.16 & - & -- \\
\hline 25: Contingency & $=$ & $=$ & $=$ & 5.29 & $=$ & $=$ \\
\hline Totals & - & - & - & 26.45 & - & - \\
\hline
\end{tabular}


Table C3.b Cost (\$ thousands) for DECON of a small hot cell at the ${ }^{25} \mathrm{Cs}$ Jaboratorysupercorppaction w/incineration

\begin{tabular}{|c|c|c|c|c|c|c|}
\hline Cost item & $\begin{array}{l}{ }_{H}{ }_{H} \\
\text { lab }\end{array}$ & $\begin{array}{l}\text { "C } \\
\text { lab }\end{array}$ & $\begin{array}{l}12 \pm J \\
\text { lab }\end{array}$ & $\begin{array}{c}{ }^{17} C_{5} \\
\text { abb }\end{array}$ & $\begin{array}{l}\text { Am } \\
\text { tab }\end{array}$ & $\begin{array}{l}\text { User } \\
\text { Inb }\end{array}$ \\
\hline Manpower & - & - & - & 5.13 & - & - \\
\hline Equipment \& supplies & , - & - & - & 2.33 & - & - \\
\hline \multicolumn{7}{|l|}{ Wasie msnagemert } \\
\hline Packaging & 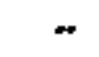 & 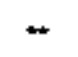 & - & 0.43 & $*$ & 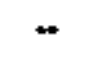 \\
\hline Processing (supereompaction) & - & - & - & 0.06 & - & - \\
\hline Processing (incineralion) & - & - & - & 0.49 & - & - \\
\hline Transportation & - & - & - & 0.08 & - & - \\
\hline Dispessol & $=$ & $=$ & $=$ & 12.90 & $=$ & $=$ \\
\hline Waste management sublotats & - & 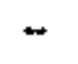 & - & 13.96 & $\bullet$ & 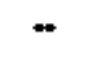 \\
\hline Total & - & - & - & 21,43 & - & - \\
\hline $25 \%$ Contingency & $=$ & $=$ & $=$ & 5,36 & $=$ & $=$ \\
\hline Total/w conlingency & - & - & - & 26.78 & - & - \\
\hline
\end{tabular}

\section{C.4 Laboratory Workbenches}

Estimated costs for decpmnissioning a workbench at each facility are shown in Table C.4.a for Option 1 and in 'Table C.4.6 for Option 2. Tolat costs ipclude manpawer, equipment and supplies, and waste managerrent costs. The workbenches vary in siza and composition, from facility os facility:

${ }^{3} \mathrm{H}$ [ab: $\quad$ Six bencties, mild stee] construction with plastic laminated top, 20 meters total length

"4C lab: $\quad$ Four benches, painted wood with plastic laminaled tops, 15 meiers totel length

12I lab: Two bercites, mild paisted steel with stalnless steel tops, 8 melers total length

${ }^{13} \mathrm{Cs}$ lsh: $\quad$ One bench, painted wood with plastic laninaled top, four melers long

24+Am lab: One bench, painted mild steel with stainless steel top, 2 meters long

User lab: Two benches, wood with plastic laninated tops, 24 meters tocal length

In order to make meaningful pooptarisons, the costs shown in Tables C.4.A and C.4.b are normalized for a bench 4.9 meters ( 16 feet) longe. (All benches are assurzed to be $0.75 \mathrm{~m}$ wide) As can be seen from these tables, there ts no obvious relation between the compostion of a bench (wood or melal) and its DECON cost. 
Table C.4.a Cost (\$ thousands) for DECON of a workbench at each os the indicated faciritiessupercompaction option

\begin{tabular}{|c|c|c|c|c|c|c|}
\hline Cost item & $\begin{array}{l}\text { '11 } \\
\text { Lab }\end{array}$ & $\begin{array}{l}{ }^{14} \mathrm{C} \\
\text { lab } \\
\end{array}$ & $\begin{array}{l}\text { 1291 } \\
\text { labj }\end{array}$ & $\begin{array}{c}{ }^{137} \mathrm{Cs} \\
\text { lab! }\end{array}$ & $\begin{array}{c}{ }^{\mu t} \text { Am } \\
\text { lab }\end{array}$ & $\begin{array}{l}\text { Ustrr } \\
\text { lob } \\
\end{array}$ \\
\hline Manpower & 1.28 & $3.8 \mathrm{I}$ & 4.37 & 4.51 & 538 & 3.57 \\
\hline Equipment \& supplies & 0.45 & 1.43 & 1.91 & 2.05 & 202 & 1.13 \\
\hline \multicolumn{7}{|l|}{ Waste mansgement } \\
\hline Packaging & 0.03 & 0.19 & 0.05 & 0.20 & 008 & 0.19 \\
\hline Processing (supercompaction) & 0.06 & 040 & 0.11 & 0.43 & 016 & 0.42 \\
\hline Processing (incineratıon) & - & - & - &. & - & - \\
\hline Transpertalion & $00 \mathrm{I}$ & 0.06 & 0.02 & 0.06 & 0.02 & 0.06 \\
\hline Disposal & $\mathbf{2} 28$ & 202 & 0.53 & 2.15 & OBP2 & 2.10 \\
\hline Waste managentent subiotals & 0.37 & 2.67 & 0.70 & 2.84 & 109 & 2.37 \\
\hline Tolal & 2.11 & 791 & 6.99 & 940 & 849 & 7.46 \\
\hline 25\% Contingency & $\underline{0.53}$ & 198 & $\underline{1.75}$ & 2.35 & 2.12 & 187 \\
\hline Totals & 263 & 9.89 & 8.74 & 11.75 & 1061 & 9.33 \\
\hline
\end{tabular}

Table C.4.b Cost (S thousands) for DECON of a workbench at each of the indicated lactitiessupercompaction w/inciperation

\begin{tabular}{|c|c|c|c|c|c|c|}
\hline Cost ilem & $\begin{array}{l}\text { 'H } \\
\text { lab }\end{array}$ & $\begin{array}{l}{ }^{1+C} \mathrm{C} \\
\text { lab }\end{array}$ & $\begin{array}{l}\text { las } \mid \\
\text { lab }\end{array}$ & $\begin{array}{c}{ }^{137} \mathrm{Cs} \\
\text { lab }\end{array}$ & $\begin{array}{c}{ }^{21} \mathrm{Am} \\
\text { lab }\end{array}$ & $\begin{array}{l}\text { User } \\
\text { lob } \\
\end{array}$ \\
\hline Manpower & 1.28 & 381 & 4.37 & 4.51 & 5,38 & 3.57 \\
\hline Equipment \& supplies & 0.45 & 1,43 & 1.91 & 2.05 & 202 & 1.13 \\
\hline \multicolumn{7}{|l|}{ Waste management } \\
\hline Packaging & 0.03 & 0.19 & 0.05 & 0.20 & 008 & 0.19 \\
\hline Processing (supercompaction) & 0.05 & 0.05 & 007 & 0.05 & 014 & 0.05 \\
\hline Processing (incineration) & $0 . J 0$ & 3.64 & 0.35 & 3.88 & 0.28 & 3,78 \\
\hline Transportalion & 001 & 0.03 & $0.0 \mathrm{~J}$ & 0.03 & 0.02 & 0.03 \\
\hline Disposal & $\underline{025}$ & 0,77 & $\underline{041}$ & 082 & 073 & 0.80 \\
\hline Waste management sublotals & 0.43 & 4.67 & 0.90 & 4,98 & 1.24 & 4.85 \\
\hline Total & 2.16 & 9.92 & 7.18 & 11.54 & 864 & 9.55 \\
\hline $25 \%$ Contingency & 0.54 & 248 & 1.80 & 2.88 & 216 & 2.39 \\
\hline Totals & 270 & 12.40 & 8.98 & 14.42 & 10.80 & 11.93 \\
\hline
\end{tabular}




\section{C.5 Ventilation Ductwork}

Estimaled costs for decommissioning ductwork at each facility are shown in Tabie C.S. a for Option I sad in Table C S.b for Option 2. Total costs include manpatrer, equipment and supplies, and waste management costs. The posis in these tables are based on a total ductwork length of 40 meters. About half the length consists of 0.1 m-diameter shet metal; the reminining length censists of 0.25 by 0.60 -m rectangular sheet metal. The exact ratio of cylindrical to rectangular ductwork varies from factisty to facility.

\section{C.6 Cabinets}

Most of the reference facilities contain one or more wood or metal cabinels as indicated.
${ }^{3} \mathrm{H}$ lab:
14C lab:
Two wood cabinets, $0.76 \mathrm{~m} \times 0.46 \mathrm{~m} \times 1.5 \mathrm{~m}$
125I lab:
Two wood cabinets, $0.76 \mathrm{~m} \times 0.46 \mathrm{~m} \times 1.5 \mathrm{~m}$.
I3'Cs lab:
One steel eabinet, $0.76 \mathrm{~m} \times 0.61 \mathrm{~m} \times 1.5 \mathrm{~m}$ with a $1.5 \mathrm{~m} \times 0.5 \mathrm{~m} \times 2.0 \mathrm{~m}$ steel shelf unit.
24+Asn lab:
User lab:
None.
One wood calinet, $0.76 \mathrm{~m} \times 0.46 \times 1.5 \mathrm{~m}$.
None.

Estimated costs for decommissioning one eabinet, etther wood or melal, at each facility are shown in Toble C.6.a for Option 1 and in Table C.6.b for Option 2. Total cosss include manpower, equipment and supplies, and waste management costs.

Table C.5. Cost (\$ thousands) for DECON of $40 \mathrm{~m}$ of ventlation ductwork at each of the indleated facilties-supercompaction option

\begin{tabular}{|c|c|c|c|c|c|c|}
\hline Cost item & $\begin{array}{l}\text { MH } \\
\text { lab }\end{array}$ & $\begin{array}{l}{ }^{31} \mathrm{C} \\
\text { lab }\end{array}$ & $\begin{array}{l}\text { 12ud } \\
\text { Leb }\end{array}$ & $\begin{array}{c}{ }^{1 \pi} \mathrm{Cs} \\
\text { lab }\end{array}$ & $\underset{\text { lab }}{u_{\text {lam }}}$ & $\begin{array}{l}\text { User } \\
\text { lab }\end{array}$ \\
\hline Manpower & 7.16 & 7.25 & 8.28 & 8.83 & 787 & 7.90 \\
\hline Equipment \& supplies & 2.51 & 2.72 & 3.62 & 4,00 & 2.94 & 2.49 \\
\hline \multicolumn{7}{|l|}{ Waste Managernent } \\
\hline Packaging & 0.06 & 0.06 & 0.06 & 0.06 & 0.09 & 0.07 \\
\hline Processing (supercompaction) & 0.13 & 0.14 & 0.12 & 0.14 & 0.19 & 0.15 \\
\hline Processing (incineration) & - & - & - & - & - & - \\
\hline Tramsportation & 0.02 & 0.02 & 0.02 & 0.02 & 0.03 & 0.02 \\
\hline Disposal & 0.64 & 069 & 0.62 & 0.69 & 0.96 & 0.75 \\
\hline Waste management subtotals & 0.84 & 0.91 & 0.82 & 0.91 & 1.27 & 0.99 \\
\hline Total & 10.51 & 10.89 & 12.72 & 13.75 & 12.08 & 11.38 \\
\hline 25\% Contúngency & 2.67 & 2,22 & 3.18 & 3.44 & $\mathbf{3 0 2}$ & 2.84 \\
\hline Tocnls & 13,14 & 13.6] & 15.90 & 17.18 & 15.10 & 14.22 \\
\hline
\end{tabular}


Table C.5.b Cost (\$ thousands) for DECON of $40 \mathrm{~m}$ of ventitation ductwork at each of the indleated faclltikes-supercompection w/nciperation

\begin{tabular}{|c|c|c|c|c|c|c|}
\hline Cost ittem & $\begin{array}{r}\text { 'H } \\
\text { lab } \\
\end{array}$ & $\begin{array}{l}\text { "c C } \\
\text { lab }\end{array}$ & $\begin{array}{l}125 \\
\text { lab }\end{array}$ & $\begin{array}{c}{ }^{15} \mathrm{Cs} \\
\text { tab }\end{array}$ & $\begin{array}{c}\text { Pll Am } \\
\text { ab }\end{array}$ & $\begin{array}{l}\text { User } \\
\text { lab }\end{array}$ \\
\hline Manpower & 7.16 & 7.25 & 828 & 8.83 & 7.87 & 7.90 \\
\hline Equipmeat \& stpplies & 251 & 2.72 & 3.62 & 4.00 & 2,94 & 2.49 \\
\hline \multicolumn{7}{|l|}{ Waste managemenl } \\
\hline Packaging & 0.06 & 0.06 & 0.06 & 0,06 & 0.09 & 0.07 \\
\hline Processing (supercompaclion) & 0.07 & 0.08 & 0.07 & 0.08 & 0.14 & 0.09 \\
\hline Processing (incineration) & 0.55 & 0.57 & 0.54 & 0.63 & 0.58 & 0.61 \\
\hline Transportation & 0.01 & 0.02 & 0.01 & 0.01 & 0.02 & 0.02 \\
\hline Disposal & 0.45 & $\underline{0.50}$ & $\underline{0.43}$ & $\underline{0.47}$ & 077 & 0.54 \\
\hline Waste management subtctals & 1.14 & 1.22 & $1 . \$ 1$ & 1.26 & 1.59 & 1.32 \\
\hline Toual & 10.81 & 11.20 & 13.02 & 14.10 & 12.40 & 11.31 \\
\hline $25 \%$ Contingency & 2.70 & 2.80 & 3.25 & 3.52 & 3.10 & 2.93 \\
\hline Totals & 13.51 & {$[4,00$} & 16.27 & 17.62 & 15.50 & 14.64 \\
\hline
\end{tabular}

Tabie C.6. Cost (\$ thousands) for DECON of a cabinel at each of the indicated facilltessupercompoctlon option

\begin{tabular}{|c|c|c|c|c|c|c|}
\hline Cost item & ${ }_{3}^{3} \mathbf{H}$ & $\begin{array}{l}\text { "C. C } \\
\text { lob }\end{array}$ & ${ }_{6}^{315}$ & $\begin{array}{c}{ }^{15} \mathrm{Cs} \\
\text { bb }\end{array}$ & ${ }_{\mathrm{Amb}}^{2 \mathrm{Am}_{\mathrm{Am}}}$ & $\begin{array}{l}\text { User } \\
\text { lab }\end{array}$ \\
\hline Manpower & 0.97 & 0.97 & 1.16 & - & 0.97 & - \\
\hline Equipment \& supplies & 0.34 & 0.36 & 0.51 & - & 0.37 & 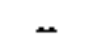 \\
\hline \multicolumn{7}{|l|}{ Waste managertatl } \\
\hline Packaging & 0.04 & 0.04 & 0.01 & $\leftrightarrow$ & 0.04 & - \\
\hline Processing (supereorlpaction) & 0.09 & 0.09 & 0.02 & - & 0.09 & - \\
\hline Processing (incineration) & - & - & - & - & - & - \\
\hline Transportation & 0.01 & 0.01 & 0.00 & - & Q.01 & - \\
\hline Disposal & 0,46 & $0 \pm 6$ & 0.10 & $=$ & $\underline{0.44}$ & $=$ \\
\hline Waste management subtotals & 0.60 & 0.60 & 0.13 & - & 0.58 & $*$ \\
\hline Total & 1.92 & 1.94 & 1.80 & - & 1.92 & 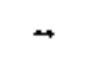 \\
\hline 25\% Contingency & 0,48 & 0.48 & 0.45 & $=$ & $B A B$ & $=$ \\
\hline Totals & 240 & 2.42 & 2.25 & - & 2.40 & - \\
\hline
\end{tabular}


Table C6,b Cost (5 thousands) for DECON of a cablnet at each of the indiented facilitiessupercompaction winciperation

\begin{tabular}{|c|c|c|c|c|c|c|}
\hline Cost itern & $\begin{array}{l}{ }^{5} \mathrm{H} \\
\text { bab }\end{array}$ & $\begin{array}{l}\text { "4C } \\
\text { lob }\end{array}$ & $\begin{array}{l}\text { las } \\
\text { lab }\end{array}$ & $\begin{array}{c}{ }^{19 n} \mathrm{Cs} \\
\text { lab }\end{array}$ & $\begin{array}{c}{ }_{\text {lab }}^{\mathbf{w}_{\mathrm{Am}}} \\
\end{array}$ & $\begin{array}{l}\text { User } \\
\text { Inb }\end{array}$ \\
\hline Manpowet & 0.97 & 0.97 & 1.16 & - & 0.97 & - \\
\hline Equipment \& supplies & 0.34 & 0.36 & 0.51 & - & 0.37 & - \\
\hline \multicolumn{7}{|l|}{ Waste managentent } \\
\hline Packoging & 0.04 & 0.04 & 0.01 & - & 0.04 & - \\
\hline Processing (superctornpaction) & 0.01 & 0.04 & 0.01 & - & $0.0 \mathrm{~J}$ & - \\
\hline Processing (inciperation) & 0.83 & 0.83 & 0.09 & - & 0.79 & - \\
\hline Transportation & $0.0 \mathrm{~J}$ & 0.01 & 0.00 & - & 0.01 & - \\
\hline Disposal & 0.17 & 0.17 & 0.07 & $=$ & 017 & $=$ \\
\hline Waste management subtotals & 1.06 & 1.06 & 0.17 & - & 1.01 & - \\
\hline Total & 2,38 & 2.39 & 1.85 & - & 2.35 & - \\
\hline 25\% Contingenty & $\underline{0.59}$ & 260 & 0.46 & $=$ & 0.59 & $=$ \\
\hline Totals & 297 & 2.99 & 2.31 & - & 2.94 & ـ \\
\hline
\end{tabular}

\section{C.7 Sizks and Drains}

One or mort sinks and drains are present in each of the reference laborateries except the laboratory for the manufacture of 'H-tabeled eompounds and the laboralory for the manufacture of ${ }^{21}$ Am sesled sourees. The sinks are used for personal cleanliness and $f(x$ washing or rinsing notheontaminated glasswate of glassware that has peviously been contantinated. Becetuse conkinuintated liquids are not purposely discharged to the sanitay sewer via these sinks, they are pastulated to have low kevels of radiaxiclve contamination.

Estimated cosst for deconrnissioning a typical sink and drain at each facility are shown in Table C.7.a for Option 1 and in Table C.7.b for Option 2. Total costs include manpower, equipment and supplies, and waste managentent costs.

\section{C.8 Freezers and Refrigerators}

Most facilities contain one or more of each of these appliances. It is assumed in this sudy that each refrigerator and freezer measures $0.65 \mathrm{~m} \times 0.61 \mathrm{~m} \times 1.52 \mathrm{~m}$ and weighs $68 \mathrm{~kg}$. These units are assumed to be only mildly contaninated inside, but exterior contamination levels are assurned to be sufficiently high that it is impractical to attempt to decontaminate them to levels required for unrestrikted use. Thrs, they are assurred to be disposed of as radioaetive $L \mathbf{L} W$ wilh only minimal decontamination.

Estimated costs for decontuissioxing a typical refrigerator or freeser at each facility are stown in Table C.8.a for Option 1 and in Table C.B.b for Option 2. Totsl cosis include manpawer, equipment and supplies, and waste management costs. 
Appendix C

Table C.7.a Cost (\$ thousands) for DECON of a sink or drain at exch of the Indicated faclllies-supereompaction option

\begin{tabular}{|c|c|c|c|c|c|c|}
\hline Cost ittem & $\begin{array}{l}\text { 'H } \\
\mathbf{l} b \mathbf{b}\end{array}$ & $\begin{array}{l}10 \mathrm{C} \\
\mathrm{lab}\end{array}$ & $\begin{array}{l}1251 \\
\text { lab }\end{array}$ & $\begin{array}{c}{ }^{137} \mathrm{Cs} \\
\text { lab }\end{array}$ & $\begin{array}{c}\mathrm{Ml}_{\mathrm{Am}} \\
\text { lab }\end{array}$ & $\begin{array}{l}\text { User } \\
\text { bob }\end{array}$ \\
\hline Manpower & $\vec{r}$ & 0.57 & 0.62 & 0.67 & - & 0.57 \\
\hline Equipment \& supplies & - & 0.22 & 0.27 & 0.30 & + & 0.18 \\
\hline \multicolumn{7}{|l|}{ Waste management } \\
\hline Packaging & - & 0.07 & 0.07 & 0.07 & - & 0.07 \\
\hline Processing (supencompaction) & - & 0.15 & 0.55 & 0.15 & - & 0.15 \\
\hline Processing (incineration) & - & - & - & - & - & 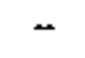 \\
\hline Transpoctation & - & 0.02 & 0.02 & 0.02 & - & 0.02 \\
\hline Disposal & $=$ & $\underline{0.77}$ & 0.77 & 0.77 & $\Rightarrow$ & 0.77 \\
\hline Waste mangentent subiocals & - & I.0! & 1.01 & 1.01 & - & 1.02 \\
\hline Total & - & 1.80 & 1.90 & 2.99 & - & 1.77 \\
\hline 25\% Contingency & $=$ & 0.45 & 0.47 & 0.50 & $=$ & 0.44 \\
\hline Totals & - & 2.25 & 2.37 & 2.49 & - & $2.2 \mathrm{l}$ \\
\hline
\end{tabular}

Table C.7.b Cost (\$ thousands) for DECON of a strk or draln at each of the Indicaled facilities-supercompaction winclaeration

\begin{tabular}{|c|c|c|c|c|c|c|}
\hline Cost Item & $\begin{array}{l}\text { 3t } \\
\text { lab }\end{array}$ & ${ }_{\mathrm{lab}}^{14 \mathrm{C}}$ & $\begin{array}{l}\text { tso } \\
\text { lab }\end{array}$ & $\begin{array}{l}{ }^{17} \mathrm{Cs} \\
\text { lab }\end{array}$ & $\begin{array}{c}\mathbf{H}_{\mathrm{Am}} \\
\mathrm{beb}\end{array}$ & $\begin{array}{c}\text { User } \\
\text { lnb }\end{array}$ \\
\hline Manpower & - & 0.57 & 0.62 & 0.67 & - & 0.57 \\
\hline Equipmert \& supplies & - & 0.22 & 0.27 & 0.30 & - & 0.18 \\
\hline \multicolumn{7}{|l|}{ Waste Managernent } \\
\hline Packaging & - & 0.07 & 0.07 & 0.07 & $\rightarrow$ & 0.07 \\
\hline Processing (supercompaction) & - & 0.15 & 0.15 & 0.15 & - & 0.15 \\
\hline Processing (Incireration) & - & 0.02 & 0.02 & 0.02 & - & 0.02 \\
\hline Transportstion & - & 0.02 & 0.02 & 0.02 & $*$ & 0.02 \\
\hline Disposal & $=$ & 0.76 & 0.76 & 0.76 & $=$ & 0.76 \\
\hline Waste manjagetrent sublotals & - & 1.02 & 1.02 & 1.02 & - & 1.03 \\
\hline Total & - & 3.81 & [.9! & 200 & - & 1.78 \\
\hline 25\% Contingency & $=$ & 0.45 & 0.48 & 0.50 & $=$ & 0.44 \\
\hline Totals & - & 2.26 & 239 & 250 & . & 2.22 \\
\hline
\end{tabular}

NUREO/CR-6477

C.10 
Table C.8.a Cost (5 thousands) for DECON of a treezer or refritgeralar at each of the indicaled facltties $\rightarrow$ upercompaction option

\begin{tabular}{|c|c|c|c|c|c|c|}
\hline Cost liem & $\begin{array}{r}\mathbf{3} \mathbf{H} \\
\text { lab }\end{array}$ & $\begin{array}{l}{ }^{14} \mathrm{C} \\
\mathrm{lab}\end{array}$ & $\begin{array}{l}\text { 10t1 } \\
\text { lab }\end{array}$ & $\begin{array}{l}{ }^{5 x} \mathrm{Cs} \\
\mathbf{b} b\end{array}$ & $\begin{array}{c}211 \mathrm{Am} \\
\text { lab }\end{array}$ & $\begin{array}{c}\text { User } \\
\text { lab }\end{array}$ \\
\hline Manpower & 1.24 & 1.27 & 1.38 & - & - & 1.25 \\
\hline Equipment \& supplies & 0.44 & 0.48 & 0.61 & - & - & 0.39 \\
\hline \multicolumn{7}{|l|}{ Waste managemtent } \\
\hline Packeging & 0.21 & 0.21 & 0.21 & - & - & $0.2 \mathrm{I}$ \\
\hline Processing (supersompaction) & 0.46 & 0.46 & 0.46 & - & - & 0.46 \\
\hline Processing (inciceration) & - & - & - & - & - & - \\
\hline Transportation & 0.07 & 0.07 & 0.07 & - & - & 0.07 \\
\hline Disposal & 230 & 2.30 & 2.31 & $=$ & $=$ & 2.31 \\
\hline Wasit management subtotals & 3.03 & 3.03 & 3.05 & - & - & 3.05 \\
\hline Total & 4.70 & 4.78 & 5.03 & - & - & 4.69 \\
\hline $25 \%$ Contingency & 1.18 & 1.20 & $\underline{1.26}$ & $=$ & $=$ & 7ل. \\
\hline Totels & 5.88 & 5.98 & 6.29 & - & - & 5.86 \\
\hline
\end{tabular}

Table C8.b Cost (s thousands) for DECON of a treezer or refrigerator at exch of the indieoled facillites-supercompaction wincineration

\begin{tabular}{|c|c|c|c|c|c|c|}
\hline Cost litem & 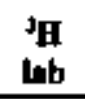 & $\begin{array}{l}{ }^{14} \mathrm{C} \\
10 \mathrm{~b}\end{array}$ & $\begin{array}{l}\text { tsuj } \\
\text { lab }\end{array}$ & $\begin{array}{l}{ }^{27} \mathrm{Cs} \\
\text { lab }\end{array}$ & $\begin{array}{c}\text { 2n }_{\text {Am }} \\
\text { lab }\end{array}$ & $\begin{array}{l}\text { User } \\
\text { lab }\end{array}$ \\
\hline Manpower & 1.24 & 1.27 & 1.38 & - & - & 1.25 \\
\hline Equipment \& atpplies & 0.44 & 0.48 & 0.61 & - & - & 0.39 \\
\hline \multicolumn{7}{|l|}{ Waste managemtent } \\
\hline Packiging & 0.21 & 0.21 & 0.21 & $\leftarrow$ & - & 0.21 \\
\hline Pracessing (supercontpaction) & 0.40 & 0.40 & 0.41 & - & - & 0.41 \\
\hline Processing (inctineration) & 0.52 & 0.52 & 0.52 & $*$ & - & 0.52 \\
\hline Trsnsporation & 0.06 & 0.06 & 0.06 & - & - & 0.06 \\
\hline Disposal & 2.12 & 2.12 & 2.13 & $=$ & $=$ & 2.13 \\
\hline Waste management subtotals & 3.32 & 3.32 & 3.33 & $=$ & - & $\mathbf{3 . 3 3}$ \\
\hline Total & 4.99 & 5.07 & 5.32 & - & - & 4.98 \\
\hline 25\% Contingency & $\underline{t .25}$ & 1.27 & 1.33 & $=$ & $=$ & 1.24 \\
\hline Tot:ls & 6.24 & 6.34 & 6.65 & - & - & 6.22 \\
\hline
\end{tabular}




\section{C.9 Filters}

The ventilation exhaust systers at each facility include roughing and HEPA filcer combinations that sene the glove boxes and fume hoods. Estimated costs for decommissioning a typical filter combination at each facility are shown in Table C.9.a for Option 1 and in Table C.9.b for Option 2. Total costs include manpower, equiprnent and supplies, and waste management costs.

\section{C.10 Building Surfaces}

Facitity ceilings, walls, and floors are decontaminaled to unfestricted release levels. Contarninated maltrial, subch as acoustic ceiting paneis, concrele chipped from walls or floors, or floor tiles are packaged and shipped to an LL,W burial site.

The reference laboratories assumed for theso docommissioring cost evaluations meastue $6 \mathrm{~m}$ by $10 \mathrm{~m}$, with walls $3 \mathrm{~m}$ high. This translates into a total wall area of $96 \mathrm{~mm}^{2}$ and s ceiling and floce area of $60 \mathrm{~m}^{2}$. The surface materials vsed itt each lab are specified in Appendix D. Tables C.10.a, C. $1 \mathrm{l}$.a, and C.12.a show the estimssed costs for decommissioning $60 \mathrm{~m}^{2}$ of ceilings, walls and Doors at the various facilities using Option 1. Costs for Option 2 are shown in Tables C.10.b, C.11.b, and C.I2.b. To allow direec comparison with ceiling and wall costs, Tables C.1 1 .a and C.11.b have been adjusted to show DECON costs for $60 \mathrm{~m}^{2}$ of wail area, even though tho total watl area for the reference laboratories is $96 \mathrm{~m}^{2}$.

Tabłe C9-a Cost (\$ thousands) for DECON ar a HEPA or ronghing frliter at each of the ind leated facilitles-supercompaction option

\begin{tabular}{|c|c|c|c|c|c|c|}
\hline Cost item & $\begin{array}{l}\text { Ju } \\
\text { lab }\end{array}$ & $\begin{array}{l}14 \mathrm{C} \\
\ln b\end{array}$ & $\begin{array}{l}{ }^{52} \text { I } \\
\text { bb }\end{array}$ & $\begin{array}{l}{ }^{n \prime} \mathrm{Cs} \\
\text { lab }\end{array}$ & $\begin{array}{c}{ }^{2 n} \mathrm{Am} \\
\mathrm{bb}\end{array}$ & $\begin{array}{c}\text { User } \\
\text { lab } \\
\end{array}$ \\
\hline Manpower & 0.06 & 0.07 & 0.08 & 0.08 & 0.07 & 0.07 \\
\hline Equipanent \& supplies & $0.0 \mathbf{2}$ & 0.03 & 0.03 & 0.04 & 0,03 & 0.02 \\
\hline \multicolumn{7}{|l|}{ Waste menagernent } \\
\hline Packaging & $<0.01$ & 40.01 & $<0.01$ & $<0.01$ & $<0101$ & $<.01$ \\
\hline Processing (supercompaction) & 0.00 & 0.00 & 0.01 & 0.01 & 0.00 & 0.00 \\
\hline Processing (jncineralion) & + & - & - & - & - & - \\
\hline Transpontation & $<0.01$ & $<0.01$ & $<0.01$ & $<0.01$ & $<0.01$ & $<0.01$ \\
\hline Disposal & $\underline{0.02}$ & 0.02 & 0.04 & Q.04 & 003 & 0.02 \\
\hline Waste management subtetals & 0.03 & 0.03 & 0.05 & 0.05 & 0.04 & 0.03 \\
\hline Total & 0.11 & 0.12 & 0.16 & 0,17 & 0.14 & 0.12 \\
\hline 26\% Contingeacy & 0.03 & 0.03 & 0.04 & 0.04 & 0.04 & 003 \\
\hline Totals & 0.14 & 0.15 & 0.20 & 0.21 & 0.18 & 0.15 \\
\hline
\end{tabular}


Table C.9.b Cost (\$ thousands) for DECON or roughing filler at each of the indicaled tacilities-supercompaction whocineration

\begin{tabular}{|c|c|c|c|c|c|c|}
\hline Cost item & $\begin{array}{l}\text { d'H } \\
\text { lab }\end{array}$ & $\begin{array}{l}\text { "c C } \\
\text { lab }\end{array}$ & $\begin{array}{l}115 \mathbf{l} \\
\text { Iab }\end{array}$ & $\begin{array}{c}{ }^{137} \mathrm{Cs} \\
\text { lab }\end{array}$ & $\begin{array}{c}\mathrm{H}_{\mathrm{Am}} \\
\mathbf{l a b}\end{array}$ & $\begin{array}{l}\text { User } \\
\text { lab }\end{array}$ \\
\hline Manpowtr & 0.06 & 0.07 & 0.08 & 0.08 & 0.07 & 0.07 \\
\hline Equipment $\&$ supplies & 0.02 & 0.03 & 0.03 & 0.04 & 0.03 & 0.02 \\
\hline \multicolumn{7}{|l|}{ Waste managensent } \\
\hline Packaging & $<0.01$ & $<0.01$ & $<0.01$ & $<0.01$ & 40.1 & $<0.0 !$ \\
\hline Processing (supercompaction) & - & - & - & - & - & - \\
\hline Processing (incineration) & 0.04 & 0.04 & $0.0 ?$ & 0.08 & 0.06 & 0.04 \\
\hline Transportation & $<0.0 \mathrm{C}$ & $<0.01$ & $<0.01]$ & $<0.01$ & $<0.01$ & $<0.01$ \\
\hline Disposat & 0.01 & 001 & $\underline{0.01}$ & 0.01 & 0.01 & 0.01 \\
\hline Waste managerrept subtotals & 0.05 & 0.05 & 0.09 & 0.10 & 0.97 & 0.05 \\
\hline Total & 0.14 & 0.14 & 0.20 & 0.21 & 0.17 & 0.14 \\
\hline $25 \%$ Contingeacy & $\underline{0.03}$ & $\underline{0.04}$ & $\underline{0.05}$ & $\underline{0.05}$ & 이 & 0.04 \\
\hline Totals & 0.17 & 0.18 & 0.25 & 0.26 & 0.22 & 0.18 \\
\hline
\end{tabular}

Table C.10.a Cost (\$ thousands) for DECON of a ceillng $\left(60 \mathrm{~m}^{2}\right.$ ) at each of the ladieated facillites-supercompaction option

\begin{tabular}{|c|c|c|c|c|c|c|}
\hline Cost ftem & $\begin{array}{l}\text { 3h } \\
\text { lab }\end{array}$ & $\begin{array}{l}\text { "tC C } \\
\text { lab }\end{array}$ & $\begin{array}{l}\text { 129I } \\
\text { loh }\end{array}$ & $\begin{array}{l}{ }^{13} \mathrm{Cs} \\
\text { lab }\end{array}$ & $\begin{array}{c}\lambda_{1} \mathrm{Am} \\
\mathrm{lab}\end{array}$ & $\begin{array}{l}\text { User } \\
\text { lab }\end{array}$ \\
\hline Manpower & 4.00 & 4.08 & 5.49 & 6.57 & 5.09 & 4.68 \\
\hline Equitprem \& supplies & 1.41 & 1.54 & 2.42 & 2.99 & 1.92 & 1.48 \\
\hline \multicolumn{7}{|l|}{ Waste managertent } \\
\hline Packaging & 0.28 & 0.28 & 0.25 & 0.64 & 0.20 & 0.55 \\
\hline Processing (supercompaction) & 0.60 & 0.59 & 0.48 & 1,34 & 0.38 & 1.18 \\
\hline Processing (incineration) & - & - & - & - & - & - \\
\hline Transportation & 0.04 & 0.08 & 0.07 & 0.20 & 0.06 & 0.17 \\
\hline Disposal & $\mathbf{3 . 0 3}$ & 2.99 & 3.33 & Z4AI & 263 & 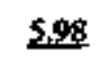 \\
\hline Waste pasnagement subtotals & 3.99 & 1,3494 & 4.14 & 9.59 & 3.26 & 7.88 \\
\hline Total & 9.40 & 9.57 & 12.05 & 19.15 & 30.27 & 14.04 \\
\hline $25 x_{0}$ Contingency & 2.35 & 2.39 & 3.01 & 4.79 & 2.57 & $3.5 I$ \\
\hline Totals & 11.76 & 11.96 & 15.07 & 23.94 & 1284 & 17.55 \\
\hline
\end{tabular}


Table C.10.h Cost ( 5 thousands) for DECON of a celling $\left(60 \mathrm{~m}^{2}\right)$ at each of the Indleated faclities-supertompaction w/muciaeration

\begin{tabular}{|c|c|c|c|c|c|c|}
\hline Cost Iten & $\begin{array}{l}\text { 3h } \\
\mathbf{l} b \mathbf{b}\end{array}$ & $\begin{array}{l}{ }^{10} \mathrm{C} \\
\text { lab }\end{array}$ & $\begin{array}{l}12 \mathrm{~J} \\
\mathrm{bab}\end{array}$ & $\begin{array}{l}157 \mathrm{Cs} \\
\mathrm{lab}\end{array}$ & ${ }_{\text {lab }}^{\mathrm{Ha}_{\mathrm{Am}}}$ & $\begin{array}{l}\text { User } \\
\text { teb }\end{array}$ \\
\hline Manpower & 4.00 & 4.08 & 5.49 & 6.57 & 5.09 & 4.68 \\
\hline Equipment \& supplies & 1.41 & 1.54 & 2.42 & 2.99 & 1.92 & 1.48 \\
\hline \multicolumn{7}{|l|}{ Wasie matagement } \\
\hline Packaging & 0.28 & 0.28 & 0.25 & 0.64 & 0.20 & 0.55 \\
\hline Processing (strpercompaction) & 0.06 & 0.06 & 0.12 & 0.19 & 0.09 & 0.12 \\
\hline Processing (incineration) & 5.54 & $\$ .47$ & 3.72 & 11.85 & 2.92 & 10.94 \\
\hline Transportation & 0.04 & 0.04 & 0.05 & 0.11 & 0.04 & 0.09 \\
\hline Disposal & 1.12 & للب & 205 & 3.33 & $\underline{1.62}$ & 2.21 \\
\hline Waste managemient stubtolals & 7.04 & 6.95 & 6.19 & 16.12 & 4.87 & 13.50 \\
\hline Total & $12, A 5$ & 12.58 & 14.10 & 25.67 & 11.88 & 20.06 \\
\hline 25\% Contingency & 3.11 & 3.14 & 3.53 & 6.42 & 2.97 & 5.01 \\
\hline Tatals & 15.57 & 15.72 & 17.63 & 32.09 & 14.85 & 25.07 \\
\hline
\end{tabular}

Table C.11.a Cost (\$ thousands) for DECON of walls $\left(60 \mathrm{~m}^{2}\right)$ at each of the Indlcated facilities-sopereompaction option

\begin{tabular}{|c|c|c|c|c|c|c|}
\hline Cost titem & $\begin{array}{l}\text { 'H } \\
\text { lab }\end{array}$ & "C & $\begin{array}{l}1251 \\
\mathbf{b a b}\end{array}$ & $\begin{array}{l}{ }^{157} \mathrm{Cs} \\
\text { wb }\end{array}$ & $\underset{\mathrm{l}}{\mathrm{lmb}_{\mathrm{Am}}}$ & $\begin{array}{c}\text { User } \\
\text { lab }\end{array}$ \\
\hline Manpower & 3.65 & 3.80 & 5.50 & 5.46 & 4.92 & 654 \\
\hline Equipment \& supplites & 1.29 & 1.44 & 2.42 & 2.49 & 1.85 & 2.07 \\
\hline \multicolumn{7}{|l|}{ Waste management } \\
\hline Packaging & 0.19 & 0.19 & 0.23 & 0.22 & 0.15 & 0.23 \\
\hline Processing (supercompaction) & 0.36 & 0.36 & 0.43 & 0.34 & 0.28 & 0.44 \\
\hline Processing (incineration) & - & - & - & - & $\leftrightarrow$ & $\rightarrow$ \\
\hline Transportation & 0.06 & 0.06 & 0.07 & 0.06 & 0.04 & 0.07 \\
\hline Disposal & 2,46 & 2.63 & $\mathbf{3 . 1 8}$ & 3.63 & 1.93 & 3.12 \\
\hline Waste management subtotsls & 3.06 & 3.25 & 3.91 & 4.25 & 241 & 3.86 \\
\hline Toul & 7.99 & 8.48 & 11.83 & 12.21 & 9.18 & 1247 \\
\hline 25\% Contingency & 2.000 & 2.12 & 2.96 & 3.05 & 2.29 & 3.12 \\
\hline Totals & 9.99 & 10.60 & 14.79 & 15.26 & $\mathrm{Jl}, 47$ & 15.59 \\
\hline
\end{tabular}


Table C.11b Cost ( $\$$ thousinds) for DECON of walls $\left(60 \mathrm{~m}^{\mathrm{d}}\right)$ at ench of the biticaled faclities-supercompaction whacineratlon

\begin{tabular}{|c|c|c|c|c|c|c|}
\hline Cost itern & $\begin{array}{l}{ }^{3} \mathbf{H} \\
\mathbf{l a b}\end{array}$ & $\begin{array}{l}14 \mathrm{C} \\
\mathrm{lab}\end{array}$ & $\begin{array}{l}115 t \\
10 b\end{array}$ & $\begin{array}{c}{ }^{M} \mathrm{Cs} \\
\mathrm{lab}\end{array}$ & $\begin{array}{c}24 \mathrm{Am} \\
\mathrm{lab}\end{array}$ & $\begin{array}{c}\text { User } \\
\text { lab }\end{array}$ \\
\hline Manpower & 3.65 & 3.80 & 5.50 & 5.46 & 4.92 & 6.54 \\
\hline Equipment \& supplies & 1.29 & 1.44 & 2.42 & 2.49 & 1.85 & 2.07 \\
\hline \multicolumn{7}{|l|}{ Waste thanagerfent } \\
\hline Packaging & , $\mathbf{0 . 1 9}$ & 0.19 & 0.29 & 0.22 & 0.15 & 0.23 \\
\hline Processing (supercompaction) & 0.09 & 0.09 & 0.17 & 0.09 & 0.07 & 0.11 \\
\hline Processing (jncínexation) & 2.76 & 2.80 & 2.64 & 2.65 & 2.17 & $\mathbf{3 . 3 8}$ \\
\hline Transportation & 0.03 & 0.04 & 0.05 & 0.04 & 0.03 & 0.04 \\
\hline Disposal & $\$ .51$ & 167 & 2.2.8 & 2.72 & 1.19 & 1.96 \\
\hline Waste management subjotals & 4.58 & 4.79 & 5.36 & 5.71 & 3.60 & 5.72 \\
\hline Total & $9.5]$ & 10.02 & 13.29 & 13.66 & 10.37 & 14.33 \\
\hline $25 \%$ Contingency & 2,38 & 2.55 & 3.32 & 3.42 & 2.59 & 158 \\
\hline Totals & 11.69 & 12.53 & 16.61 & 17.08 & 12.96 & 17.91 \\
\hline
\end{tabular}

Toble C.12. Cost (5 thousands) for DECON of a floor $\left(60 \mathrm{~m}^{2}\right)$ at each of the indicated facilities-supercompoction aption

\begin{tabular}{|c|c|c|c|c|c|c|}
\hline Cost item & $\begin{array}{l}{ }^{3} \mathbf{H} \\
\mathbf{l a b}\end{array}$ & ${ }^{x} \mathrm{C}$ & $\begin{array}{l}\text { HI } \\
\mathbf{E} \mathbf{I} \mathbf{b}\end{array}$ & ${ }_{\mathrm{H}}^{\mathrm{tr}} \mathrm{Cs}$ & $\begin{array}{c}21 ! \mathrm{A} \\
\text { lab }\end{array}$ & $\begin{array}{c}\text { User } \\
\text { lab }\end{array}$ \\
\hline Manpowet & 5.25 & 551 & 5.97 & 6.53 & $5.4 \mathrm{~L}$ & 5.87 \\
\hline Equipment \& supplies & 1.85 & 2.08 & 2.63 & 2.98 & 204 & 1.86 \\
\hline \multicolumn{7}{|l|}{ Waste maragerment } \\
\hline Packaping & 0.07 & 0.09 & 0.10 & 0.10 & 0.20 & 0.10 \\
\hline Processing (supercompaction) & o.ts & 0.20 & $0.2 I$ & 0.21 & 0.38 & 0.23 \\
\hline Processing (tncineration) & - & - & $\leftarrow$ & $\leftarrow$ & - & - \\
\hline Transportation & 0.02 & 0.03 & 0.03 & 0.03 & 0.06 & 0.03 \\
\hline Dispousal & $\underline{0.74}$ & p.99 & 20.5 & t.05 & 263 & 1.14 \\
\hline Waste maragement subtotals & 0.97 & 1.30 & 1.38 & 1.38 & 3.26 & 1.50 \\
\hline Total & 8.08 & 8.89 & 9.98 & 10.88 & 10.71 & 9.23 \\
\hline $25 \%$ Conting & 208 & 2.22 & 250 & 2.72 & 2.68 & 2.31 \\
\hline Totals & 10.10 & 11.11 & 12,48 & 13.60 & 13.39 & 11.54 \\
\hline
\end{tabular}


Appendix C

Table C.12.b Cost ( $\$$ thousands) for DECON of a flow (60 $\left.\mathrm{m}^{2}\right)$ at each of the indicated facllities-supercompaction wincineration

\begin{tabular}{|c|c|c|c|c|c|c|}
\hline Cost Ittern & $\begin{array}{l}\text { 's } \\
\text { lab }\end{array}$ & $\begin{array}{l}{ }^{4} \mathrm{C} \\
\mathrm{bb}\end{array}$ & $\begin{array}{l}\text { Is } \\
\text { lab }\end{array}$ & $\begin{array}{l}{ }^{15} \mathrm{Cs} \\
\text { lab }\end{array}$ & $\begin{array}{c}\mathrm{m}_{\mathrm{Am}} \\
\text { 的b }\end{array}$ & $\begin{array}{l}\text { Uster } \\
\text { Iob }\end{array}$ \\
\hline Manpower & 5.25 & 5.51 & 5.97 & 6.53 & 5.41 & 5.87 \\
\hline Equipment \& supplies & 1.85 & 2.08 & 2.63 & 2.98 & 204 & 1.86 \\
\hline \multicolumn{7}{|l|}{ Wasto marageniem } \\
\hline Packaging & 0.07 & 0.09 & 0.10 & 0.10 & $0.20^{\circ}$ & 0.10 \\
\hline Frocessing (supereompaction) & 0.15 & 0.16 & 0.16 & 0.16 & 0.09 & 0.19 \\
\hline Processing (incineration) & - & 0.37 & 0.53 & 0.53 & 292 & 0.37 \\
\hline Transportalion & 0.02 & 0,03 & 0.03 & 0.03 & 0.04 & 0.03 \\
\hline Dispossal & $\underline{0.74}$ & $\underline{0.86}$ & 0.86 & 0.86 & 162 & 1.01 \\
\hline Waste management sublotals & 0.97 & 1.50 & $1.6 ?$ & 1.67 & 4.87 & 1.70 \\
\hline Total & 8.08 & 9.09 & 10.28 & 11.17 & 12.32 & 9.43 \\
\hline 25\% Contingency & 202 & 2.27 & 2.57 & 2.79 & 3.08 & 2.36 \\
\hline Totals & 10.10 & It.36 & 12.84 & 13,97 & 15.40 & 11.79 \\
\hline
\end{tabular}




\section{Appendix D}

\section{Details of Decommissioning Reference Facilities}




\section{Appendix D}

\section{Details of Decommissioning Reference Facilities}

This appendix provides detailed descriptions (sizes, areas, weights, and volumes) of each potentially contaminated component in the six reference facilities. The methods used to partially dexontaninzte ankf tronove the compontents are also described. At the end of each major section, detailed cost and monpower breakdowns for the factlity being analyzed are given for the two decomrnissioning options: (1) DECON with supercompaction and (2) DECON with supercompaction ard incineration.

\section{D.1 Reference Laboratory for the Manufacture of ${ }^{3} \mathrm{H}$-Labeled Compounds}

Detafled physical descriptions and decommissioning procedures for all the companents and building surfaces of the 'H laboralory that are postulated to require removal and/or decontaningtion are given in Sections D.l.1 through D.I.J0. Details of (1) planning and preparation, (2) estimated manpower requirements, (3) waste management, materials, and labor costs, and (4) rediatlon dosages are presented in Table D.11 for the supercompaction option and in Tabje D.Jb for the supercompaction option with incinezalion. An overall description of this laboratory is contained in Sextion 7.1. of Reference 1.

\section{D.1.1 Fune Foods}

The ${ }^{2} \mathrm{H}$ facility contalns fove fune hoods, each measuring $1.5 \mathrm{~m}$ wide $\times 2.0 \mathrm{~m}$ high $\times 0.945 \mathrm{~m}$ deep. Fach hood is assumed to be framed externally by mild steel 0.003175 meters thick. Hach bood is equipped with m acrylic window $0.00635 \mathrm{~m}$ thikk. The hood is assumed to rest on an enclosed stainless steel-based cabinet (Fig A.5-1. Reference 1). The support cabinet is essumed to have the same foot print as the fume hood bul is only $0.9 \mathrm{~m}$ high.

As with essexxislty all other materials from the various NFC facilities, the fumb hoods and the lower cobinets upon which they rest are assumed to be cut up. packaged, and placed in 208-liter drums for fisposal as $L L W$ waste. The ipterior and exterior of the tume hood surfaces are firse vacuumed and wet-wiped, then dried and painted to fix conbanination. The hoods are then cur to sizes that allow the hood moterials to be bagged and placed in 208-liter drums in ruch a way that the materials can be reasonably compacted or-site, then supercompacied off-site.

Amount of Sielaless Sied in the Upper Sectlon

Back: $1.5 \times 2.0$

Two sides: $2 \times 0.945 \times 2.0$

Floor and Top: $2 \times 1.5 \times 0.945$

Total Area

Total Volume $0.003175 \times 9.615$

Total Volume for 5 Hoods

Total Weight for 5 Hoods

$$
\begin{aligned}
& =3.00 \mathrm{~m}^{2} \\
& =3.78 \mathrm{~m}^{2} \\
& =2.835 \mathrm{~m}^{2} \\
& =9.615 \mathrm{~m}^{2} \\
& =0.03053 \mathrm{~m}^{2} \\
& =0.1526 \mathrm{~m}^{3} \\
& =1,221 \mathrm{~kg}
\end{aligned}
$$




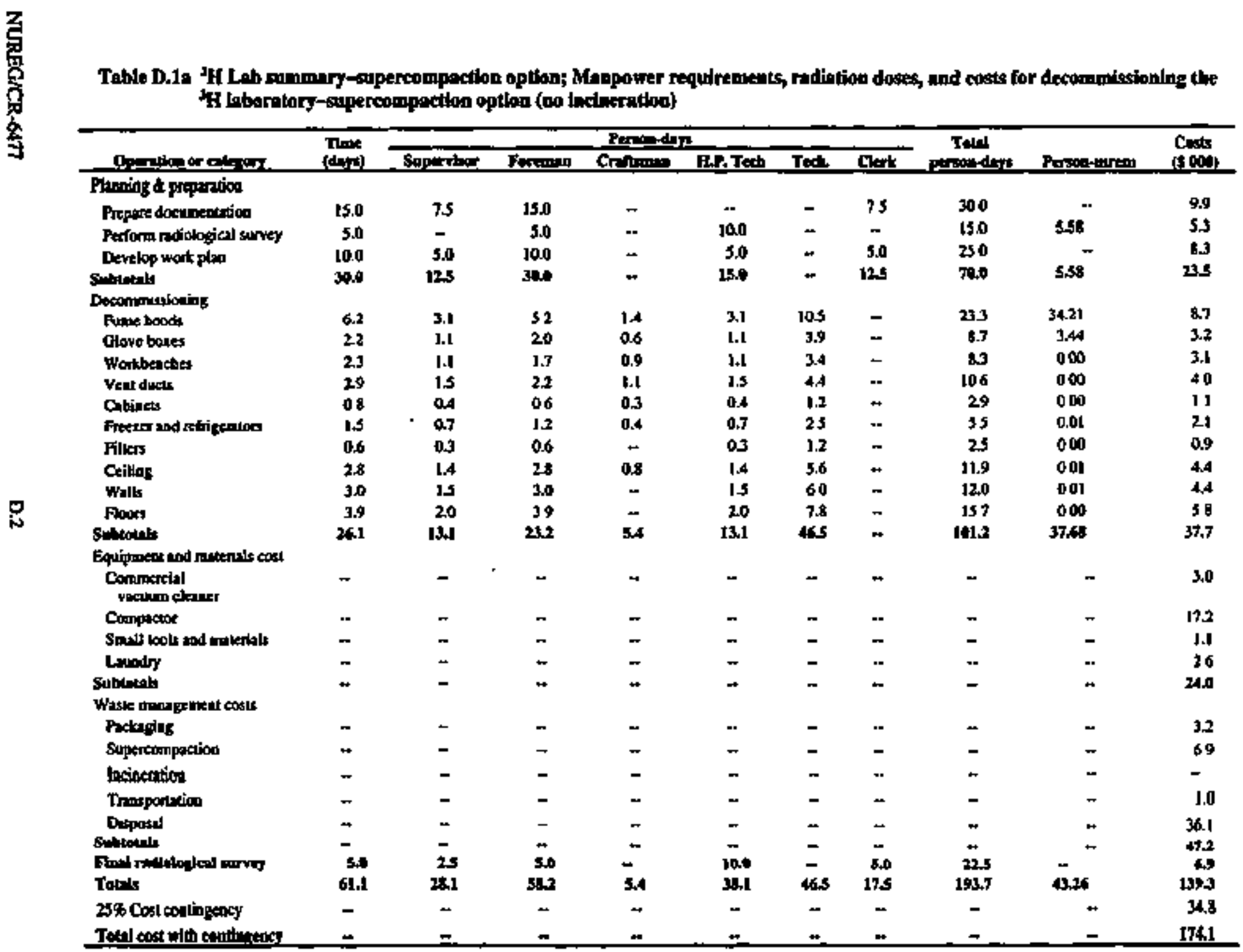




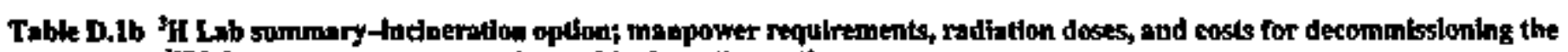
${ }^{3} H$ babowtory -supereompaction and incineration option

\begin{tabular}{|c|c|c|c|c|c|c|c|c|c|c|}
\hline \multirow[b]{2}{*}{ Operelien or enteitr } & \multirow{2}{*}{$\begin{array}{l}\text { Time } \\
\text { (date) }\end{array}$} & \multicolumn{6}{|c|}{ Patolidatat } & \multirow{2}{*}{$\begin{array}{c}\text { Tool } \\
\text { peranters }\end{array}$} & \multirow[b]{2}{*}{ Person-intent } & \multirow{2}{*}{$\begin{array}{l}\text { Cosits } \\
\text { is } 4 \text { (4) }\end{array}$} \\
\hline & & Superitar. & Forecing & Croflon & H.P. Tech & Texh & Clerk & & & \\
\hline Pluaning \& prepuration & & - & & & & & & & & \\
\hline Prepare documentation & 150 & 73 & 150 & - & $=$ & - & 75 & 300 & $*$ & 99 \\
\hline Ptritorm nediotogial stricty & 50 & - & 50 & .- & 100 & - & - & 15.0 & s.sa & 53 \\
\hline Develop work pdin & 100 & $\$ 0$ & 100 & - & 50 & 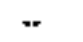 & 50 & 250 & .. & 83 \\
\hline Sublimb & 300 & 125 & $\mathbf{3 0 . 0}$ & $*$ & 19.0 & - & 12.5 & 20,4 & s.5s & 23. \\
\hline \multicolumn{11}{|l|}{ Deconondsshoriag } \\
\hline Fime hoods & 6.2 & 3.1 & 5.2 & 1.4 & 31 & 10.5 & - & 233 & 34.21 & 8.7 \\
\hline Olove bouses & 2.2 & 1.1 & 20 & 06 & t.I & 3.9 & - & 8.7 & 344 & 3.2 \\
\hline Workbeacties & 2.3 & 1.1 & 1.7 & 0.9 & t.1 & 3.4 & - & 8.3 & 000 & 31 \\
\hline Veal ducts & 2.9 & is & 22 & 1,1 & 15 & 44 & - & 106 & 000 & 40 \\
\hline Cebinets & 0.5 & 04 & 06 & 03 & 0,4 & 12 & - & 2.9 & 000 & 1.1 \\
\hline ' Freezet and nefígerdions & 1.5 & 07 & 5.2 & 04 & 0.7 & 25 & 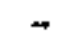 & 5.5 & 001 & 21 \\
\hline Alters: & 06 & 03 & 06 & $*$ & 03 & 1.2 & - & 25 & 000 & 09 \\
\hline Colling & 20 & 1.4 & 28 & 00 & 1,4 & 56 & 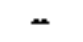 & 119 & 001 & 44 \\
\hline Watts & 30 & Is & 30 & - & 15 & 60 & - & 120 & 001 & 44 \\
\hline Froons & 3.9 & 20 & 39 & - & 20 & 78 & 4 & 15.7 & 000 & 58 \\
\hline Swbletaln & 26,1 & J3.1 & 23.3 & 5.4 & 13.1 & 16.5 & $\rightarrow$ & 101.2 & 37.68 & 37.7 \\
\hline \multicolumn{11}{|l|}{ Equipencent and materists cost } \\
\hline Contractial vacurm cleaser & $=$ & - & - & - & - & - & - & - & 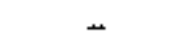 & 30 \\
\hline Conopactur & $=$ & - & - & - & - & - & - & - & $+\cdot$ & 172 \\
\hline Srrall toolt and twierials & $*$ & - & - & -. & $=$ & - & $*$ & - & - & $1 . \mathrm{I}$ \\
\hline Lanody & - & - & - & - & - & - & -. & -. & -. & 26 \\
\hline \multirow{2}{*}{\multicolumn{11}{|c|}{ Watse minagrencat cogta }} \\
\hline & & & & & & & & & & \\
\hline Pxkrging & - & - & - & - & - & - & 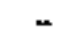 & $=$ & $=$ & 32 \\
\hline Srpercoupution & - & $\leftrightarrow$ & 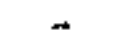 & - & - & - & . & - & - & 43 \\
\hline moinesation & - & - & - & - & - & - & - & - & - & 264 \\
\hline Tratspuntation & - & - & 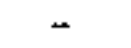 & - & - & - & - & $=$ & - & 00 \\
\hline Disposil & - & - & - & - & - & - & - & -- & - & 270 \\
\hline Subrotes:s & $\dot{*}$ & 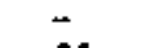 & $=$ & $=$ & $=$ & -. & - & $\ddot{-}$ & - & 61.8 \\
\hline 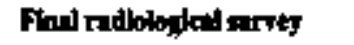 & 5.0 & $\mathbf{2 . 5}$ & 5.0 & - & 100 & $*$ & $\mathbf{5 , 0}$ & 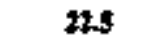 & $*$ & 6 \\
\hline Touls & 61.1 & 281 & stit & $\$ .4$ & 30.1 & 465 & 17.5 & 198.7 & 43.26 & 151, \\
\hline $25 \%$ Cost cosatiagency & - & - & - & - & 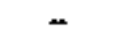 & $*$ & - & - & - & 385 \\
\hline 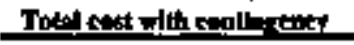 & ـ & - & $\rightarrow$ & - & 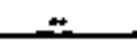 & - & 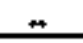 & $\Rightarrow$ & - & 1223 \\
\hline
\end{tabular}


Appendix D

\section{Amount of Stalnless Steped in the Lower Cobinet}

Back \& Front: $2 \times 1.5 \times 0.90$

Two Sides: $2 \times 0.945 \times 0.9$

Bottom \& Top: $2 \times 1.5 \times 0.945$

Tolal Avea

To1al Volume: $0.003175 \times 7.236$

Total Volume for 5 Hoods

Total Weight for 5 Hoods

$$
\begin{aligned}
& =2.700 \mathrm{~m}^{2} \\
& =1.701 \mathrm{~m}^{2} \\
& =2.835 \mathrm{~m}^{2} \\
& =7.236 \mathrm{~m}^{2} \\
& =0.02297 \mathrm{~m}^{2} \\
& =0.1149 \mathrm{~m}^{3} \\
& =919 \mathrm{~kg}
\end{aligned}
$$

\section{Amount of Mild Steet In the Exterior Frante}

The frame is assurmed to be cornprised of angic iron ( $0.0508 \mathrm{~m}$ by $0.04445 \mathrm{~m}$ by $0.0047625 \mathrm{~m}$ thick). The amount of mild steel is $4 \times 2.0 \mathrm{~m}$ for vertical members and $4 \times 1.5 \mathrm{~m}$ for horizontal members, for a total tength of $14 \mathrm{~m}$. Total mild steel in the fume hood frame is thus $14 \mathrm{~m} \times(0.0508+0.04445) \times 0.0047626=0.006351 \mathrm{~m}$.

Total Volume for 5 Hoods

Tatal Weight for 5 Hoods

$$
\begin{aligned}
& =0.03176 \mathrm{~m}^{3} \\
& =254 \mathrm{~kg}
\end{aligned}
$$

\section{Amount of Acrylle Flastic in the Windov}

The plastic is assumed to be $2,0 \mathrm{~m}$ high $\times 1,5 \mathrm{ml}$ wide $\mathrm{x} 0.00635 \mathrm{~m}$ thick, for a total volume of $0.01905 \mathrm{~m}$.

Total Volurne for 5 Hoods

Total Weight for $\$$ Hoods (specific gravity $=1.2$ )

$$
\begin{aligned}
& =0.09525 \mathrm{~m}^{3} \\
& =\mathrm{I} 14 \mathrm{~kg}
\end{aligned}
$$

\section{Amouat of Processing Equipment}

Alhough difficutt to estimate because of the wide variety of processing equipment, an alkowance is made foc the bulk quanbity of matertals and equipment in the furse hoods. The following general type of contaminated equipment is postulalod to be present in the fume hood. The equiprnent is bagged and compacted on-site, supercompacted of f-site, and hern disposed of as LLW.

- 2 electric heating units, each wejghing ahout $7 \mathrm{~kg}$. These art assumed to take up ahout $0.03 \mathrm{~m}^{3}$ of space, each. For $S$ fume hoods, the totsl is 10 electric heating units, with a tolsl weight of $70 \mathrm{~kg}$ and a total bulk volume of $0.3 \mathrm{~m}$ '.

- 6 significzant items of processing glassware, each weighing about $3 \mathrm{~kg}$ and taking up about $0.02 \mathrm{~m}^{3}$ of space. For 5 fume hoods, the toeal is 30 units of processing glassware, with a total weight of $90 \mathrm{~kg}$ and a total bulk wolume of $0.6 \mathrm{~m}$.

- 4 jtems of various materials (metals, plastic, ceramic), each weighing about $2 \mathrm{~kg}$. These are assuroed to take tep about $0.014 \mathrm{~m}^{2}$ of space, each. For 5 fome hoods the total is 20 items, with a total wtight of $40 \mathrm{~kg}$. and a tolal bulk volume of $0.284 \mathrm{~m}^{2}$.

\section{D.1.2 Glove Boxes}

The ${ }^{3} \mathrm{H}$ facility contains six giove boxes. Each neasures $0.9 \mathrm{~m}$ wide $\mathrm{x} 0.6 \mathrm{~m}$ high $\times 0.6 \mathrm{~m} \mathrm{deep}$ (Reference 1. p. A-33), rests on a workbench (Reference 1, p. 7-8), and is assuned to be framed by mild steel extemally, with 0.003175-m-thick stainless steed walls, and 0.00635-m-thick axtylic windows. The glove box has a stainless sleel pantel acrooss the Iower $0.25 \mathrm{~m}$ of the front, in which are located two 0.2 -m-diarneter circular openings for plastic warting glaves. Above this pasel. the front of 
the glove box slopes backward at an angle of about 40 degees, providing an opening for the acrylic plastic viewing window. The viewing wipdow is mourted in 2 mild steel metal frame which is gasketed to the sliping front of the glove box. At one end of the glowe box is a slainless steel airlock far the insertion of equipment and miterial imlo the box. Airlock dimensions are $0.3 \mathrm{~m}$ tight $\times 0.2 \mathrm{~m}$ wide $\times 0.2 \mathrm{~m}$ deep (Reference $1, \mathrm{p}$. A.33). One acrylic air lock door ts accessible from outside the glove box, and one is arcessible from inside the box through the use of glove ports. Standard electrical reteptacles are becated on the inside of the glove box, wìth power controlled by switches mounted outside on a service panel above the glove box.

Before the glove boxes art dismanuled, the interior and exterior surfaces are vacultmed and wet-wiped, and then painled to fix conianination. The glove boxes are then cut to sizes that allow the baged glove box materials to go iato 208-liter drums in such a way that the materials can be reasonably compacted on-sile, supercompaceded off-site, and then disposed of as $L W$. The acrylie plastic, the steel materials, and the equiprners inside the glove box are segegated into 208-liter drums, eathi wish one of these categories of materials.

\section{Amount of Stainless Steel in Glove Box and Access Air Lock}

Glove Box Proper.

Back: $0.9 \times 0.6$

Bottoris: $0.9 \times 0.6$

Two sides: $2 \times 0.6 \times 0.6$

Top: $0.3 \times 0.9$

Lower Front Paned: $0.25 \times 0.9$

Total Area

Total Valune: $0.003175 \times 2.295$

Total Volume for 6 Boxes

Total Wetght for 6 Boxes

$$
\begin{aligned}
& =0.54 \mathrm{~m}^{2} \\
& =0.54 \mathrm{~m}^{2} \\
& =0.72 \mathrm{~m}^{2} \\
& =0.27 \mathrm{~m}^{2} \\
& =0.225 \mathrm{~m}^{2} \\
& =2.295 \mathrm{ml}^{7} \\
& =0.00729 \mathrm{ml}^{3} \\
& =0.0437 \mathrm{~m}^{3} \\
& =350 \mathrm{~kg}
\end{aligned}
$$

Air Lock.

Back: 0.3 $\times 0.2$

Top, Side, Botom: $3 \times 0.2 \times 0.2$

Total Ares

Total Volume: $0.003175 \times 0.18$

Total Volume for 6 Boxes

Total Weight for 6 Boxes

Tota' Stainless Stecl Volume for 6 Boxes

Total Stainless Steel Weight for 6 Boxes

$$
\begin{aligned}
& =0.06 \mathrm{~m}^{2} \\
& =0.12 \mathrm{~m}^{2} \\
& =0.18 \mathrm{~m}^{2} \\
& =0.0005715 \mathrm{~m}^{\prime} \\
& =0.00343 \mathrm{~m}^{3} \\
& =27 \mathrm{~kg} \\
& =0.0472 \mathrm{~m}^{2} \\
& =377 \mathrm{~kg}
\end{aligned}
$$

\section{Amount of Midi Steel in the Exterior Erame}

The frame is assumed to be comprised of angle tron (0.0518 m by $0.04445 \mathrm{~m}$ by $0.0047625 \mathrm{~m}$ thick). The amount of mild ateel is $4 \times 0.6 \mathrm{~m}$ for vertical members and $4 \times 0.9 \mathrm{~m}$ for hocizontal metrbers, far a totsl length of $6.9 \mathrm{~m}$ Total mild steel in the frame is thas $6.9 \times(0.05018+0.04445) \times 0.0047626=0.00313 \mathrm{mt}$. 
Appendix D

\section{Ameant of Acryle Phatle in the Main Whotow and Air Lack}

Maln Window. The plastic is assumed to be $0.6 \mathrm{~m}$ high $\times 0.9 \mathrm{~m}$ wide $\times 0.00635 \mathrm{~m}$ thick, giving a volpme of $0.003429 \mathrm{~m}^{3}$.

Total Volune for 6 Boxes

Total Weight for 6 Boxes (s.g. $=1.2$ )
$=0.020574 \mathrm{~m}^{3}$

$=24.7 \mathrm{~kg}$

Alrtock. Each of the two wincows is assumed to measure $0.3 \mathrm{~m} \times 0.2 \mathrm{~m} \times 0.00635 \mathrm{~m}$. This gives a total volumite of 0.000762 ?

Total Volume for 6 Boxes

Total Weight for 6 Boxes (s.g. $=1.2$ )

Total Volume of Acrylic for 6 Boxes

Total Weight of Acrylic for 6 Boxes

$$
\begin{aligned}
& =0.004572 \mathrm{~m}^{j} \\
& =5.5 \mathrm{~kg} \\
& =0.02515 \\
& =30 \mathrm{~kg}
\end{aligned}
$$

\section{Amount of Processing Equipment}

The following gewery type of contaminated equipnent is pastulated to be present in the glove boxes. The equipment is bagged and compacted an-site, super-compacted off-site, and then disposed of as $\mathrm{LW}$;

- 2 electric healing units, each wejghing about $7 \mathrm{~kg}$. These are assumed to take up about $0.03 \mathrm{~m}^{3}$ of spate, each. For the 6 glove boxes, the total is t2 electric heating units, with a total weight of $84 \mathrm{~kg}$ and $\mathrm{x}$ total bulk volume of $0.36 \mathrm{~m}^{3}$.

- 6 significant iters of processing plassware, each weighing about $3 \mathrm{~kg}$ and taking up about $0.02 \mathrm{mt}$ of space. For 6 glove boxes, the total is 36 units of processing glassware, with a total weight of $108 \mathrm{~kg}$, and a total bulk vohume of $0.72 \mathrm{~m}^{3}$.

- 4 items of various materials (metals, plastic, ceramic), each weightng about $2 \mathrm{~kg}$. These are assurned to take up about $0.014 \mathrm{~m}^{3}$ of space, each. For 6 glove boxes the total is $24 \mathrm{ilems}$, with a total weight of $48 \mathrm{~kg}$, and a total bulk volume of $0.336 \mathrm{~m}^{3}$,

\section{D.1.3 Workbenches}

The six workbenches in the ${ }^{3} \mathrm{H}$ facility have a tottl combined length of 20 m (Reference 1, pp 7.8 \& 7-9 \& p. 9-8). The berkfes are assumed to be $8 \mathrm{~m}, 4 \mathrm{~m}, 3 \mathrm{~m}, 3 \mathrm{~m}, 1$ m, and $1 \mathrm{ml}$ kng. The workbenthes are utade of mild steel and have plasticlaminated tops and are assomed to have no drawers. The benches are $0.75 \mathrm{~m}$ wide, $0.9 \mathrm{~m} \mathrm{high}$, and are assumed to be open (like tables) 2nd stand on 0.0015875 m-thick rild steel legs that are spaced every $1.5 \mathrm{~m}$. The legs are assumed to be 0.075 m-5quare box-channels. The workbepches are postulated to have a square U-shaped chamnel all around the top, and every $0.5 \mathrm{~m}$ across the depth for structural support. These channels are postulated to be $0.05 \mathrm{~m}$ on each side and $0.0015875 \mathrm{~m}$ thick. The top steel surface is assamed w be 0.003175 meters thick. The plastic laminate top cover of the bench is assumed to be 0.0015875-rathlick polycarbonate.

To reduce loose contaminaxion, the workbenches are tirst vacuumed and wet-wiped. They are then bagzed and placed in 208-liter dniras. The drums are compacted on-site, supercompucted off-site, and then sent to disposal as LW. The dimensions and the large number of legs of the bencthes mhkes the benches relatively easy to cut into sections for salvige of some of the bench sections, if desirable. 
Amount of Mild Steel in the Workbench Tops and Rejintorcing

Top: $20 \times 0.75$

$=15 \mathrm{~m}^{2}$

U-channels Under Bench Tops: $2 \times(8+0.75)+2 \times(4+0.75)+4 \times(3+0.75)+4 \times(1+0.75)$

Area: $49 \times 3 \times 0.05$

Reinforcing U Channels:

8-m-bench; $15 \times 0.75 \times 3 \times 0.05$

4-m-bench: $7 \times 0.75 \times 3 \times 0.05$

Two 3-m-benches: $2 \times 5 \times 0.75 \times 3 \times 0.05$

Two 1-mbenches: $2 \times 1 \times 0,75 \times 3 \times 0.05$

Total Ares

$* 49$ meters (perimeter of all benches)

$=7.35 \mathrm{mi}^{2}$

Total Weight: $8000 \times 0.0654$

$=1.6875 \mathrm{~m}^{2}$

$=0.7875 \mathrm{~m}^{2}$

$=1.125 \mathrm{mi}^{2}$

$=0.225 \mathrm{~m}^{3}$

$=3.825 \mathrm{~m}^{2}$

$=523 \mathrm{~kg}$

Amount of Mild Steel th the Workbench Legs

Number of legs for 8-m-bench: $2 \times \operatorname{Im}[\$ / 1.5]$

Number of legs for 4 -m-bench: $2 \times$ Int [4/t.5]

Number of legs for both 3-m-benches: $4 x \operatorname{lnt}[3 / 1.5]$

Number of legs for both 1-m-benches:

Total Legs

Area: $34 \times 0.9 \times 4 \times 0.075$

Volume: $9.19 \times 0.0015875$

Weight: $\mathrm{B000} \times 0.1457$

$$
\begin{aligned}
& =12 \\
& =6 \\
& =8 \\
& =8 \\
& =34 \\
& =9.18 \mathrm{~m}^{2} \\
& =0.01457 \mathrm{~m}^{3} \\
& =116.6 \mathrm{~kg}
\end{aligned}
$$

\section{Amount of Polycarbongte on the Surfaces of the Workbenches}

Volume: $15 \times 0.0015875$

Weight: $1200 \times 0.0283$

$$
\begin{aligned}
& =0.0238 \mathrm{~m}^{3} \\
& =28.6 \mathrm{~kg}
\end{aligned}
$$

\section{Amount of Processing Equipment on Fach Workbench}

This is difficult to estimate because of the wide variety of processing equipment. It is assumed that the workbenches were used for radioartive counting equjpment, which had to stay clear; for wolls (again, assumed to be free of contamination) for making smail new parts for uhe hoods and glove boxes; for temporary storage of nortadioactive malerials; for weighing and overpecking the products (again, expected to be a relatively clean operation); and other sirilar uses. The following general type of contanninated equipanent is pastsanted to be present on the workbenthes.

- various hand tools including a vist, primrily steel, weighing a total estimated $30 \mathrm{~kg}$, wilh a lotal grass volume estimated to be $0.02 \mathrm{~m}^{3}$.

- 6 signifitant iterns of processing glassware, each weighing about $3 \mathrm{~kg}$ and assumed to take up about $0.02 \mathrm{~m}^{3}$ of bulk space each. For the 6 glass itents, the jtems would weigh a total of about It $\mathrm{kg}$ and require $0.12 \mathrm{~m}^{2}$ of total bulk space.

- 4 items of vrious malerials (metals, plastic, ceramic), exch weighing about $2 \mathrm{~kg}$. For these 4 items, the total weight is estimated at $8 \mathrm{~kg}$, with an estimated total volume of $0.008 \mathrm{~m}$. . 


\section{D.1.4 Vent Ducts}

The facility contains $20 \mathrm{~m}$ of cylindrical ductwork $0.2 \mathrm{~m}$ in diame1er and $20 \mathrm{~m}$ of rectangular ductwork $0.25 \mathrm{~m} \times 0.6 \mathrm{~m}$ in crisss-section (Refetence 1, p. 9-8). The ductwork is assumed to be stainless steel sheet metal $0.0015875 \mathrm{~m}$ thick. The ductwork is assumed to be radioaclively contaminated intemally and extemally. The ductwork is vacutumed and wet-wiped where possible to remove the readily-removable contamizanion, then psinted to minimize contarnination during subsequent steps. The duct waste is cut into pieces that maxintize the amount of material that can fil in 208-lite druns. The wasto pisces are placed in plastic baps before being placed in the drums. The waste-filled drums are then compacted on-site and then shipped off-site for supercompaction before disposal as $\mathrm{LW}$.

\section{Amount of Malertal in the Ductwort}

Cylindrtcal Ductwork Volume Rectangular Ductwork Volurne

Total Volume

Total Weight

$$
\begin{aligned}
& =\pi \times 0.2 \times 20 \times 0.0015875=0.020 \mathrm{~m}^{3} \\
& =2 \times(0.25+0.6) \times 20 \times 0.0015875=0.054 \mathrm{~m}^{3} \\
& =0.074 \mathrm{~m}^{3} \\
& =432 \mathrm{~kg}
\end{aligned}
$$

\section{D.1.5 Cabinets}

The ${ }^{3} \mathrm{H}$ facilty contains two cabinets, each postulated to be constructed of 0.01905-m-lhick latex-painted wood (Reference 1 . p. 9-8). The dimensions of each cabinet aro assumed to be $0.762 \mathrm{~m}$ wide $\times 0.4572 \mathrm{~m}$ deep $\times 1.524 \mathrm{mhighil.} \mathrm{Each} \mathrm{cabinet} \mathrm{is}$ assurned to have 2 lockjng doors, and 3 shelves plus the bottom instde shelf.

Both cabinets are given only mild decontamination by vacuuning and wet-wiping. The material is then painted and sectioned. The sectioned waste is then bagged and placed in 203. liter drums for on-site coenpaction. The dnums are then shipped off-site for supercompaction. If the incineration option is used, the waste is sent off-site for incineration and fixalion of the astes into a monolithic solid. The fixed solid is sent for disposal as $I L W$.

Amoant of Material in Each Cobinet to be Disposed of is Waste

Front and Back: $2 \times 0.762 \times 1.524 \times 0.01905 \quad=0.0442 \mathrm{~m}^{3}$

Two Sides: $2 \times 0.4572 \times 1.524 \times 0.01905 \quad=0.0265 \mathrm{~m}^{3}$

Top, Bottom, 3 Shelves: $5 \times 0.762 \times 0.4572 \times 0.01905 \quad=0.0332 \mathrm{~m}^{3}$

Total Vohume

Total Volume for 2 Cibinets

$=0.1099 \mathrm{~m}^{3}$

Total Wejght for 2 Cabinets (s.g. $=0.8$ ) $\quad=166.24 \mathrm{kB}$

\section{D.1.6 Freezer and Refrigerators}

The ' $H$ facility contains one freczer and two refingerators, all postulated to be upright units, with the same dimensions of $0.6096 \mathrm{ml} \times 0.60 \% 6 \mathrm{~m} \times 1.524 \mathrm{~m}$. The three anits are assomed to be only mildly contaminated inside. But coutside, the compressor, coils, fan, and other mechanisms are assumed to be sufficiently contanuiguted that it wovid not be reasonabie to try to decontaminate them to levels required for unrestricted use. Thus, they arc assumed to be disposed of as radjoaxtive waste with only minimal decontamination. It is assumed that the freon (not contaninaled) will be removed on-site by a subcontractor. The units will then be vacuuned, wiped and painted, and then cut up and bagged into 208-jiter drums for onsite compacting. The units will then be shipped off-site for supercompacting before disposal as $\amalg W$. Sectioning will be done to effectively use the space io the dums. 


\section{Amount of Materlal to the Three Units}

This is based on the grass characteristics of conventional refrigerators and freezers. Each unit will comain the jtfrigeration cooling system (copper, sleed, other tretals), some framework (mild steed), plastic inner and outer walls separated by fiberglass insulation, somm plastic trays and glass and mild steel shelves inside. The sectioned and pre-corpacted volumo of the three units is assumed to be the same as when whole, of $3 \times 0.6096 \times 0.6096 \times 1.524=1.699 \mathrm{~m}^{3}$. The overall wejght of each refrigeralor or freezes unit is assurned to be $68 \mathrm{~kg}$, for a tolsl weight of $204 \mathrm{~kg}$.

\section{D.1.7 HEPA and Roughing Futers}

Each fume hood (5) and glove box (6) in the ${ }^{3} \mathrm{H}$ facility has a HEPA and roughing filte an ils ventilation exhaust. The tacility the II HEPA and roughing filters during nonal operation (Reference 1. p. 9-8). No other HEPA or roughing etters are in the facility. It is postulated that the facility filters had been replaced at the end of the operaling period, and they will last thraughout the lotal decommisstoning period. In addtion, it is assumed that during the vacuuming activity of the components and the facility, a comnercial vacuum uni is leased that uses a roughing filter and a HEPA filter jdentical to those in the facility, and 2 sels of filters are used during vacusuming, bringing the total to 13 sets. The filter removal is one of the last activities underaken duriog decommissioning. Each falter is sented in a plastic bag during its removal. Each HEPA Flter is $0.2 \mathrm{~m}$ tn dianneter and 0.2 an high (Reference 1, p. 9-8). The mughing filters (Reference 1, p. 9-8) are $0.2 \mathrm{~m}$ in dianeter $\times 0.1 \mathrm{~m}$ tigh. It is assumed that the fattes are comprised of sheet-netal casing with pleated paper as the filter medium. It is postulated that the fiters are bagged, placed in 208 -titer druns for an-site conpaction, followed by shipment off-site for supercompaction bejore being packaged tar dispessal as $L d W$.

\section{Amount of Matertal in the HEPA and Roughing Filters}

The bolk (rectangular) valume of the 13 HIEPA filters is $13 \times 0.2 \times 0.2 \times 0.2 \pm 0.104 \mathrm{~m}^{3}$. The overall weight of each HEPA filter is assumed to be $5 \mathrm{~kg}$. Thus, the total weight of the 13 FEPA filters is $65 \mathrm{~kg}$.

The bulk (rectangular) volume of the 13 roughting filters is $13 \times 0.2 \times 0.2 \times 0.1=0.052 \mathrm{mt}^{3}$. The overall weight of each roughtiog filter is assursed to be $2.5 \mathrm{~kg}$. Thus, the total weight of the 13 roughing filters is $32.5 \mathrm{~kg}$.

\section{D.1.8 Factity Ceilling}

The ${ }^{3} \mathrm{H}$ facility ceiling consists of $120 \mathrm{~m}^{2}$ of acoustically-treated fiberboard (Referente 1, p. 9-8) that is scspended (above which some piping and electrical wiring ts mounted). The fiberboard is in panels that are typically $0.3 \mathrm{~m} \times 0.3 \mathrm{~m}$, or $0.3 \mathrm{~m} \times 0.6 \mathrm{~m}$ Each panel ean be removed separately.

The fiberbard, postulated to be $0.012 \% \mathrm{~m}$ thick, has a rough surtace and many pores, making it impractical to decontaminale. The ceiling panels are first vacuumed and painfed to fix the contanination, then are removed for disposal as radtoactive waste. The ceiling materials are broken up if necessary and baszed and inserted into 208.liter drums. The waste is then compacted on-sibe before being transported off-site for supercompaction and disposal as LLW. If the incineration option is used, the resultant ats is fixaled into a monolitic solid. The spectfic gravity (s.g.) of the fiberboard is assumed to be 0.5 .

\section{Almogpt of Mntertas lin the Cetling}

Tosal volume: $120 \mathrm{~m}^{2} \times 0.0127 \mathrm{~m}$

The eftistated pre-compacted bulk volarme is assumed to be twice the actual volume, or about $3.0 \mathrm{~m}^{3}$. The total weight is $762 \mathrm{~kg}$. 
Appendix D

\section{D.1.9 Facility Walls}

The $132 \mathrm{~m}^{2}$ of wals of the 'H facility (Reference 1, p. 9-8) are plastertoard (postulated to be 0.015875 $\mathrm{m}$ thick), painted with latex enamel. It is assumed that the wals are decontaminated to unrestricied use levels to maintatn the wall surfaces and to keep from contaminating the wall insulation and structural mernbers behind the walls. The walls are frst vacuurred, then wiped with wet rags and brushes. The decomtaninating solution, a dilute aqueous delergent, is applied sparingly to minimize dripping. After wet+wiping, the walls are wiped with dry rags and allowed to dry contipletely. For final decontamination. strippable patsl is brushed ar rolled on, allowed to dry, then stripped off with the contamination. Final hot spots are manually wet-wiped, or spot-painted again with strippable paint. Only the malerials used for decontamination are assumed to become LLW. These are bageged ant placed in 20 dititer dnums.

\section{Athouats of Weste Materinls Resulling from Decontaminatiog the Walls}

The estimalso developed in Reference 1, p. E-30, tor the washfwipe operations seem reasonable for the decontamination procedores used In that sudidy, but in this study, far less of the liquid decontaminating agent is assumed to be used, with part of the decoetamination beipg done with strippable paint. Thus, ibe amount of rags, brashes, and liguid wastes here are taken ts be $1 / 3$ of those in Reference d, with adjustomenis for watl area. The estimsies of waste malerials from decontarnination and the subseguent waste treatment are given below. Disposition of the final wastes is discussed in each of the three subsets of wasle categories below.

- 2.67208 -12ier droms of wet rags, brushes and contaminated gloves and other clothing (Reference 1). These are assumbod to be compacted on-site, sent off.shle for supercompaction and LLW disposel. If the incineration option is used, the waste is ibcinerated off-sitc, with the ashes fixed into a monolithic solid, and disposed of as LLW. Estimaled weight of these wates before treatrient is $50 \mathrm{~kg}$.

- 0.67208 -liter drums of aqueous decontanination solutions (assumed to have smal] amounts of detergents) and rinse solutions from washing/wiping decontamination, before solidification with an adsortent material, Estimated weight of the wastes before solidification is $110 \mathrm{~kg}$. The adsorted wastes are sent directy for disposal as LLW.

- 220B-liter dnums equivatent of removed strippable paint (assumed in this study) to be reduced to ope drum after on-stite cormaction. Estimated weight of the LLW is $50 \mathrm{~kg}$. The waste is compacted on-site, then sent to supercampaction for disposal as LLW.

\section{D.1.10 Facility Floor}

The floors of the ' $H$ facility (Refterence $1, p .7 .7$ ) consist of $120 \mathrm{~m}^{2}$ of asphati tile (pastulated to be $0.0015875 \mathrm{~m}$ thick) over ptyorood (postulned to be $0.01905 \mathrm{~m}$ thick). The speclfic gravity of the tiles is assumed to be 1.1 .

The floor is postulated to be fitst yacusumed and then painted of fix the remaining contanination. The tiles are removed manually and packaged in bags and placed in 208-liter drums as LW. The remaintng hot sposs in the wood sub-flooxing are cleaned by a spall amount of scraping or planing. The wood scrapings are bagged and placed in 208-tiler drums for on-site compacting, followed by off-site incineration. The tinal ash content is assumed to be $5 \mathrm{wt} \%$.

\section{Amount of Floor Tlle Wuste}

Total Volume of Fipor Tites: $120 \times 0.0015875 \quad=0.191 \mathrm{~ms}^{2}$

Toted weight of Foor Tiles: $1100 \times 0.191 \quad=210 \mathrm{~kg}$

The floor tiles are cornpacted on-site, snpercompacted oft-site, and then sent for disposal as ILW. 


\section{Amount of Wood Scroping Waste}

The amount of wood ticapings removed as rodioactive waste is difficult to estimate. A nurther of the crachs between the tiles will have contaminated wood that needs to be cemoved, probably to a depth of about $0.003 \mathrm{~m}$. The total ansoumi of wood scrapings removed as radicactive waste is assumed to be $70 \mathrm{~kg}$. with an assumed bulk specific gravity of 0.4 , for a Eross volume before cortapaction of $0.175 \mathrm{~m}^{3}$.

\section{D.2 Reference Laboratory for the Manufacture of ${ }^{14} \mathrm{C}$-Labeled Compounds}

Detailed physical descriptions and decommissioning procedures for all the components and building surfaces of the ${ }^{4} \mathrm{C}$ laboratory that are postulated to require removal and/or decontanination are given in Sections D.2.] through D.2.11. Details of (1) planning and preparation. (2) estimated manpower requirements, (3) waste managemem, materials, and labor costs, and (4) radiation dosages are presented in Table D.2a for the supercooppaction option and in Table D.2b for the supercormpaction option with jnciseration. An overall description of this laboratory is contained in Section 7.1.2 of Reference 1.

\section{D.2.1 Fume Hoods}

The ' $\mathrm{C}$ facitity contains four fome hoods, each measuring $1.5 \mathrm{~m}$ wide $\times 2.0 \mathrm{~m}$ high $\times 0.945 \mathrm{~m}$ deep. Each hood is assumed to be framed externally by mild steel $0.003175 \mathrm{~m}$ hick. Each hood is equipped with an acrylic window $0.00635 \mathrm{~m}$ thich. The hood is assumed to rest on an enclosed slainless steel-based cabinet (Fig A.S-I, Reference 1). The support cabinet is assonud to have the same foot print as the furne hood but is only $0.9 \mathrm{~m}$ high.

Before tismantling. the interior and exterior of the fume hood surfaces are first vaconumed and wet-wiped, then dried and painted in fix contamination. The hoods are then cul to sizes that allow the hood miterials to be bagged and ptaced in 208-jiter druns in such a way that the materials can be reasonably conmpacted on-site, then supercompacted off-site.

\section{A mount of Stainless Steel Upper Section}

Back: $1.5 \times 2.0$

Two sides: $2 \times 0.945 \times 2.0$

Floor and Top: $2 \times 1.5 \times 0.945$

Tot:l Area

Tatal Volume: $0.003175 \times 9.615$

Total Volume for 4 Hoods

Total Weight for 4 toods

Anowat of Stalinkess Sted in the Lower Cabinet

Bect \& Front: $2 \times 1.5 \times 0.90$

Two Sides: $2 \times 0.945 \times 0.9$

Botion \& Top: $2 \times 1.5 \times 0.945$

Total Area

Total Volurne: $0.003175 \times 7.236$

Total Volume for $\$$ Hoods

Total Weight for 4 Hoods

$$
\begin{aligned}
& =3.00 \mathrm{~m}^{2} \\
& =3.78 \mathrm{~m}^{2} \\
& =2.835 \mathrm{~m}^{2} \\
& =9.615 \mathrm{~m}^{2} \\
& =0.03053 \mathrm{Jr}^{3} \\
& =0.12212 \mathrm{~m}^{3} \\
& =977 \mathrm{~kg}
\end{aligned}
$$

$$
\begin{aligned}
& =2700 \mathrm{~m}^{2} \\
& =1.701 \mathrm{~m}^{2} \\
& =2.835 \mathrm{~m}^{2} \\
& =7.236 \mathrm{~m}^{2} \\
& =0.02297 \mathrm{~m}^{3} \\
& =0.09188 \mathrm{mi}^{3} \\
& =184 \mathrm{~kg}
\end{aligned}
$$


Table D.2* "CC Lab rammury-appercompaction option; nanpower requirenents, nadiation doses, and costs for decommlssioniag the

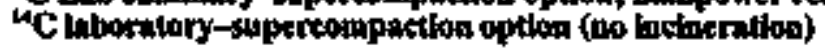

\begin{tabular}{|c|c|c|c|c|c|c|c|c|c|c|}
\hline \multirow[b]{2}{*}{ 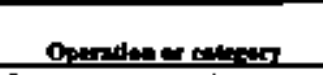 } & \multirow{2}{*}{ Thas } & \multicolumn{6}{|c|}{ 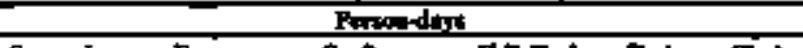 } & \multirow{2}{*}{ Told } & \multirow[b]{2}{*}{ Pasch-men } & \multirow{2}{*}{ 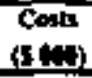 } \\
\hline & & Saponstur & Fon.?in & $\operatorname{con}$ hingen & Flented & Int. & Gat: & & & \\
\hline \multicolumn{11}{|l|}{ 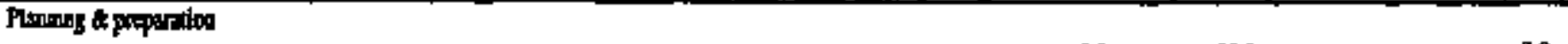 } \\
\hline Preper doculneratition & 15.0 & 13 & 15.0 & - & - & - & 7.5 & 30.0 & - & 9.9 \\
\hline Periorn advologicat suavey & 3.5 & 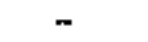 & 3.5 & - & 70 & - & - & 10.5 & 001 & 3.7 \\
\hline Denelop work pian & 100 & $\$ 0$ & 100 & - & 5.0 & - & 50 & 25.0 & - & 83 \\
\hline Subsoterti & 205 & 125 & 205 & - & 12.0 & - & 125 & 655 & 0.01 & 21.9 \\
\hline \multicolumn{11}{|l|}{ Dexompoissionung } \\
\hline Funex toods & 50 & 25 & 4.2 & I.J & 25 & 85 & - & 188 & 003 & 10 \\
\hline Glaus boxe: & 13 & 0.8 & 13 & 04 & 08 & 27 & - & 5.9 & 0.00 & 2.2 \\
\hline Woxttenander & so & 25 & $\mathbf{3} \mathbf{3}$ & 1.5 & 25 & 76 & - & 17.9 & 000 & 60 \\
\hline Val ducts & 22 & 1.1 & 16 & 00 &. .1 & 32 & . & 7.8 & 0.01 & 2.9 \\
\hline Coinew & as & 04 & 06 & 02 & 04 & 1.2 & - & 28 & 0.00 & 10 \\
\hline 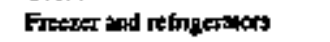 & 2.5 & 0.7 & 1.2 & 04 & 0.7 & 25 & - & 35 & 000 & 21 \\
\hline Fillar & 0.5 & 0.2 & as & - & 02 & 1.0 & - & 20 & 000 & ot \\
\hline Sink and drain & 0.2 & 0.1 & 0.2 & 0.1 & 0.1 & 04 & - & $0 \mathrm{~s}$ & 000 & 03 \\
\hline Cedunt & 18 & 0.9 & 18 & as & 09 & 3.7 & ـ & 7.9 & 000 & 29 \\
\hline Wals & 25 & 1.2 & 2.3. & - & 1.2 & 50 & - & 9.9 & 000 & 3.7 \\
\hline Fon & 2.7 & 13 & 2.7 & - & 2.3 & 53 & ـ & 106 & 0.01 & 3.9 \\
\hline 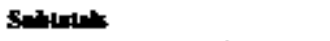 & 236 & 11. & 205 & s.o & 11.8 & 403 & 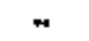 & $\boldsymbol{* 1 , 0}$ & 0.16 & 335 \\
\hline \multicolumn{11}{|l|}{ 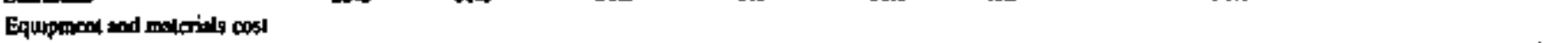 } \\
\hline Cammerasl yeraund dener & - & - & - & - & . & - & - & - & - & 30 \\
\hline Coonperar & - & - & 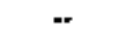 & - & - & - & - & - & - & 17.2 \\
\hline Smodil booly of mancruls & - & - & - & - & - & - & - & - & - & 1.0 \\
\hline Lamdry & - & - & - & - & - & - & - & - & - & 12 \\
\hline Substotalu & - & - & - & - & - & + & - & - & 4 & 235 \\
\hline \multicolumn{11}{|l|}{ Whste mengement cools } \\
\hline Pactagang & $*$ & - & - & - & - & - & - & - & - & 32 \\
\hline Supercoripustioe & - & - & - & - & - & + & - & - & - & $6 \mathrm{~B}$ \\
\hline Imborision & - & - & $=$ & + & - & - & - & - & .. & - \\
\hline Traspontation & - & - & - & - & - & - & - & - & - & 1.0 \\
\hline Dieposel & - & - & - & - & - & - & - & . & $\rightarrow$ & 35.9 \\
\hline Sabrotant & - & - & 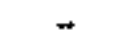 & - & - & - & - & - & - & 46.9 \\
\hline 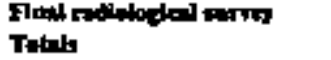 & $\begin{array}{c}5,4 \\
57.1\end{array}$ & 25 & 540 & 5.0 & 136. & 40 & Sis & 1724 & $\ddot{m}_{101}$ & 130.7 \\
\hline $25 \%$ Cose cooulntercy & - & - & - & - & $\sim$ & - & - & - & $=$ & 332 \\
\hline 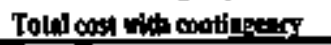 & - & * & - & $=$ & - & - & $=$ & $=$ & - & 1658 \\
\hline
\end{tabular}




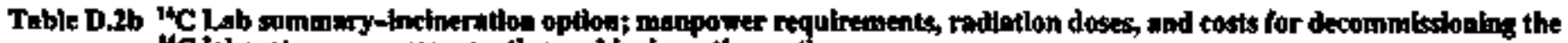

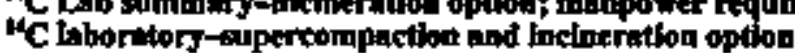

\begin{tabular}{|c|c|c|c|c|c|c|c|c|c|c|c|}
\hline & & & & Petarity & & & & & & Constis & \\
\hline 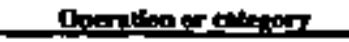 & (dist) & 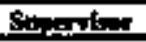 & Ferentin & Crifining & E.T.Tech & Tech & Clerk & 100-14. & Parsoouran & (8) & \\
\hline Planing \& preparatiod & & & & & & & & & & & \\
\hline Propters doctmetaline & 150 & 15 & 15.0 & + & - & - & 75 & 30.0 & $*$ & 99 & \\
\hline Penforta rodiologital survey & 35 & - & 3.5 & - & 7.0 & م & - & 105 & 001 & 3.7 & + \\
\hline Derelop wht plat & 100 & 50 & 100 & - & 5.0 & . & 50 & 250 & $*$ & 53 & \\
\hline Subintily & 28 & 12.5 & 205 & - & 12. & - & 125 & st & d.et & 21.3 & \\
\hline Decoanmissloaing & & & & & & & & & & & \\
\hline $\begin{array}{l}\text { Fume Aoxds } \\
\text { Glowe boxes }\end{array}$ & so & 2.5 & 4.2 & 1.1 & 25 & 8.5 & $=$ & $\begin{array}{r}183 \\
50\end{array}$ & 003 & 70 & \\
\hline $\begin{array}{l}\text { Glowe boxes } \\
\text { Wortbencies }\end{array}$ & 1.5 & 08 & 13 & 0.4 & 08 & 27 & - & $\begin{array}{r}5.9 \\
179\end{array}$ & $\begin{array}{l}000 \\
000\end{array}$ & 22 & \\
\hline $\begin{array}{l}\text { Wontbencis: } \\
\text { Vent duets }\end{array}$ & $\$ 0$ & 2.5 & 38 & t.5 & 25 & 2.6 & - & $\begin{array}{r}17.9 \\
78\end{array}$ & 001 & 6.7 & \\
\hline $\begin{array}{l}\text { Vent duets } \\
\text { Cabiats }\end{array}$ & 2.2 & t.1 & 26 & 0.6 & 1.1 & 32 & - & $\begin{array}{l}78 \\
28\end{array}$ & 000 & 2,9 & \\
\hline $\begin{array}{l}\text { Cabiets } \\
\text { Freezer and gefingenters }\end{array}$ & 08 & 04 & 06 & 07 & 04 & 1.2 & - & $\begin{array}{l}2.8 \\
5.5\end{array}$ & 000 & 1.8 & \\
\hline $\begin{array}{l}\text { Fieterer and refingenters } \\
\text { Fiters }\end{array}$ & 1.5 & 0.7 & 1.2 & 04 & 07 & 23 & 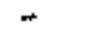 & $\begin{array}{l}5.5 \\
20\end{array}$ & 000 & 2.1 & \\
\hline $\begin{array}{l}\text { Fikets } \\
\text { Stok und datn }\end{array}$ & 0.5 & 0.2 & $0 s$ & $\sigma$ & 02 & 1.0 & - & $\begin{array}{l}20 \\
0.8\end{array}$ & 000 & 07 & \\
\hline $\begin{array}{l}\text { Stik wad drin } \\
\text { Cestang }\end{array}$ & 02 & 01 & 0.2 & 01 & 01 & 04 & . & 19 & 0,0 & 0.3 & \\
\hline $\begin{array}{l}\text { Cestins } \\
\text { Wutts }\end{array}$ & 18 & on & 18 & 05 & 09 & 3.7 & $\rightarrow$ & $\begin{array}{l}19 \\
9.9\end{array}$ & 000 & 29 & \\
\hline $\begin{array}{l}\text { Wafts } \\
\text { Floon }\end{array}$ & 2.5 & 1.2 & 23 & - & 1.2 & 5.0 & . & & 001 & 3.7 & \\
\hline 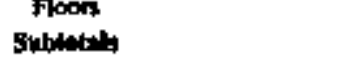 & 2.7 & 13 & 2.7 & -- & 13 & 5.3 & - & & 001 & 39 & \\
\hline Bplalpmed and moterialy post & 23.6 & 11. & 20.5 & S.0 & 11.8 & 40,5 & - & $\mathbf{9 0}, 0$ & $\$ .06$ & 335 & \\
\hline Conmentil taroum cleatet & - & - & - & - & - & - & .. & - & - & 30 & \\
\hline Composior & .. & - & - & - & - & - & .- & - & .. & 172 & \\
\hline Small took and materiats & .- & - & - & - & - & - & - & - & - & 10 & \\
\hline Louadiry & $*$ & - & - & - & - & - & - & - & 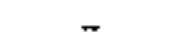 & 22 & \\
\hline Spbtolnit: & 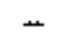 & - & $*$ & - & - & - & - & - & 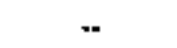 & 22.5 & \\
\hline Whate mantgemomt cinst & & & & & & & & & & & \\
\hline Puckating: & - & -- & 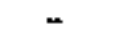 & - & " & - & -- & $*$ & - & 32 & \\
\hline Supprompurticon & - & - & -. & -. & - & - & $*$ & - & - & 31 & \\
\hline Iocteqution & - & - & $\rightarrow$ & * & - & - & .- & - & + & 32.2 & \\
\hline Transportation & - & - & - & - & .. & - & $*$ & $\leftrightarrow$ & - & $\because 07$ & \\
\hline Disposal & - & - & $\leftrightarrow$ & - & - & $\Rightarrow$ & $=$ & - & - & 248 & \\
\hline Sarlotely & - & - & - & $\omega$ & - & $=$ & . & - & - & H,T & \\
\hline 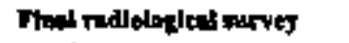 & 5,4 & 25 & 8.0 & - & 160 & $*$ & 5.0 & 22.5 & $*$ & 6.9 & \\
\hline Towats & 57.1 & $26 \%$ & S4! & 5.t. & 33.5 & 4.9. & 175 & thet & $\operatorname{ant}$ & 150.5 & \\
\hline $25 \% \operatorname{Cos}$ condingency & 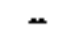 & - & - & 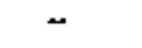 & - & $\rightarrow$ & + & - & - & 37.6 & \\
\hline 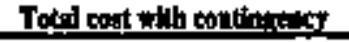 & $=$ & $H$ & \pm & $*$ & H. & $=$ & 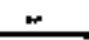 & $\sim$ & - & Itat. & \\
\hline
\end{tabular}


Appendlx D

\section{Amount of Mild Sieel in the Exterior Frame}

The frame is assumed to be made of angle inon $(0.0508 \mathrm{~m}$ by $0.04445 \mathrm{~m}$ by $0.0047625 \mathrm{~m}$ 1hick). The amount of mild sleel is $4 \times 2.0 \mathrm{~m}$ for vertical members and $4 \times 1.5 \mathrm{~m}$ for horizantal members, for a total length of $14 \mathrm{~m}$. Tolal mild steel in the fume hood frame is thus $14 \mathrm{~m} \times(0.0508+0.04445) \times 0.0047626=0.00635 \mathrm{t} \mathrm{m}$.

Total Volume for 4 Hoods

Total Weight for 4 Hoods

$$
\begin{aligned}
& =0.0254 \mathrm{~mm}^{3} \\
& =203 \mathrm{~kg}
\end{aligned}
$$

\section{Anount of Acrylie Ptastic in the Whon}

The plastic is assumed to be $2.0 \mathrm{~m}$ thigh $\times 1.5 \mathrm{~m}$ wide $\times 0.00635 \mathrm{~m}$ thick, for a total volume of 0.01905 .

Total Volume for 4 Hoods

Total Weight for 4 Hoods (s.g. $=1.2$ )

$=0.0762 \mathrm{~m}^{3}$

$$
=91.4 \mathrm{~kg}
$$

\section{Amount of Processing Equiproent}

An allowance is made for the bulk quantity of materials and equipment in the fune hoods. The following general type of contaminated equipment is postalated to be present in the fume hood. The equipment is bagged and compacted on-site. super-compscted off-site, and then disposed of as LLW.

- 2 electric heating units, each weighing aboun $7 \mathrm{~kg}$. These are assumed to take up about $0.03 \mathrm{~m}^{3}$ of space, each. For 4 fume hoods, the total is 8 electric healing units, with a total weight of $56 \mathrm{~kg}$ and a tocal bulk volume of 0.24 .

- 6 significant items of processing glassware, each weighing about $3 \mathrm{~kg}$ and taking wp about $0.02 \mathrm{~m}^{3}$ of space. For 4 fume hoods, the total is 24 units of processipg glassware, wih a total wejght of $72 \mathrm{~kg}$ and a total bulk wohrre of 0.48 .

- 4 items of various materials (metals, plastic, ceraric), each weighing about $2 \mathrm{~kg}$. These are assumed to take up about $0.014 \mathrm{~m}$ ' of space, each. For 4 furne hoods the total is 16 ilems, with a total weight of $32 \mathrm{~kg}$ and a total bulk volume of 0.224 .

\section{D.2.2 Glove Boxes}

Each of the four glove boxes (Reference 1, p. 7-12) in the "C facility is $0.9 \mathrm{~m}$ wide $x 0.6 \mathrm{~m}$ high $\times 0.6 \mathrm{mdepp}$. Each glove box is assumed to be franed by mild steel externally, with 0.003175-it-1hick stainless steel walls, and 0.00635-m-thick acrylic windows. The glove baxes rest on wood workberches (discussed in Itenn 3, below). Each glowe box has a stainiess sleel panel actoss the lower $0.25 \mathrm{~m}$ of the front, in which are located two 0.2-m-diameier circular openings for neoprese working gloves. Above this pantl, the front of the glove box slopes backward at an angle of about 40 degrees, providing an opening for the atrylic plastic viewing window. The viewing window is nowunted in a nild steel metal frame which is gasketed to the sloping front of the glove box. At nee end of two of the glove boxes is assumed to be a slainless steel aiflock for the insertion of equipment and material into the box. Airlock dimenstons are $0.3 \mathrm{~m}$ kigh $\times 0.2 \mathrm{~m}$ wide $\mathrm{x} 0.2 \mathrm{~m}$ deep (Reference 1. p. A.33). One axtytic air lock door is accessible from ontside the glove box, and one is becessible from the inside of the box through the use of glove ports. Standard electrical receptacles are located on the inside of the glove box, with power concolled by switches moonted butside on a service panel above the glove box. Two glave boxes are each silting on each of two workbenches, discussed is Section D.2.3, bejow.

Before the glove boxes are dismantited, the interior and exleriox surfaces ane vacuurned and wet-wiped, and then painted to fx conlamination. The glove boxes are then cut wo sizes that allow the bagged glove box cuterials lo go into 208-liter anums 
in such a way that the materials can be ressonably compacted on-slte, then supereormpacted off-site. The acrylic plastic, the sleel materials, and the equipments inside the glove box are segregated into 208-liter drums each with one of these categories of muterials.

Amount of Stainiess Sleel in Glove Box and Access Air Lock

Glove Box Proper.

Back: $0.9 \times 0.6$

Bottom: $0.9 \times 0.6$

Two sides: $2 \times 0.6 \times 0.6$

Tep: $0.3 \times 0.9$

$$
\begin{aligned}
& =0.54 \mathrm{~m}^{2} \\
& =0.54 \mathrm{~m}^{2} \\
& =0.72 \mathrm{~m}^{2} \\
& =0.27 \mathrm{~m}^{2} \\
& =0.225 \mathrm{~m}^{2} \\
& =2.295 \mathrm{~m}^{2} \\
& =0.00729 \mathrm{~m}^{3} \\
& =0.02916 \mathrm{~m}^{3} \\
& =233 \mathrm{~kg}
\end{aligned}
$$

Lower Front Panel: $0.25 \times 0.9$

Total Volume: $0.003175 \times 2.295$

Total Volume for 4 Boxes

Total Weighe for 4 Boxes

Air Lock.

Back: $0.3 \times 0.2$

Top, Side, Boltom: $3 \times 0.2 \times 0.2$

Totil Area

Total Volume: $0.003175 \times 0.18$

Total Volume for 2 Air Locks

Total Wtight for 2 Air Locks

$=0.06 \mathrm{~m}^{2}$

$\times 0.12 \mathrm{~m}^{2}$

$=0.18 \mathrm{~m}^{7}$

$=0.0005715 \mathrm{mr}^{3}$

$=0.0011430 \mathrm{~m}^{3}$

$=9 \mathrm{~kg}$

Total Stainless Steel Volurre for 4 Boxes

Total Stainless Steel Weight for 4 Boxes

$=0.0303 \mathrm{~m}^{5}$

$=342 \mathrm{~kg}$

Amount of Mild Steel in the Exterior Frame

The frame is assumed to be misde of tangle iron $(0.0508 \mathrm{~m}$ by $0.04445 \mathrm{~m}$ by $0.0047625 \mathrm{~m}$ thick). The arnount of mild steel is $4 \times 0.6 \mathrm{~m}$ for vertical mentiers and $4 \times 0.9 \mathrm{~m}$ for horizontal menters, for a wal length of $6.9 \mathrm{~m}$. Tolal mild steel in the frame is thus $6.9 \times(0.0508+0.04445) \times 0.0047626=0.00313$.

Total Volene for 4 Boxes

Total Weight for 4 Boxes

$$
\begin{aligned}
& =0.01252 \mathrm{~m}^{3} \\
& =100 \mathrm{~kg}
\end{aligned}
$$

Amoont of Acrylic Plastic in the Minin Window and Air Lock

Maln Window. The plastic is assumed to be $0.6 \mathrm{~m}$ high $\times 0.9 \mathrm{~m}$ wibe $\times 0.00635 \mathrm{~m}$ thick, giving a wolume of 0.003429.

Total Volume for 4 Boxes

Total Weight for 4 Boxes (s.g. $=1.2$ )

$=0.0137 \mathrm{~m}^{3}$

$=16.5 \mathrm{~kg}$ 
Appendix D

Alriock. Each of the two windows is assumed to measure $0.3 \times 0.2 \times 0.00635$. This gives a total volume of 0.000762 .

Totai Volume for 2 Boxes

Tolal Weight for 2 Boxes (s.g. $=1,2$ )

Total Volume of Acrylic for 4 Baxes

Total Weight of Acrylic for 4 Boxes
$=0.001524 \mathrm{~m}^{2}$

$=1.8 \mathrm{~kg}$

$=0.01524$

$=18.3 \mathrm{~kg}$

\section{Anount of Processing Equipment}

The following general type of contantinated equipment is postulated to be present in the glove boxes. The equipment is bagged and compacted on-site, super-compacted off-site, and then disposed of as $\mathrm{LW}$.

- 2 electric heating urits, exch wejghiog about $7 \mathrm{~kg}$. These are assumed to take up about $0.03 \mathrm{~m}^{3}$ of space, each. For the 4 glove boxes, the total is 8 electric healing units, with a total weight of $\$ 6 \mathrm{~kg}$ and a total bulk volume of 0.24 .

- 6 significant items of grocessing glassware, each weightng about $3 \mathrm{~kg}$ and taking up about $0.02 \mathrm{~m}$ ' of spact. For 4 gkova boxes, the total is 24 units of processing glassware, with a total weight of $72 \mathrm{~kg}$, and a total bulk rolurne of 0.48 .

- 4 items of various materials (metals, plastic, cerarnic), each weighing sbout $2 \mathrm{~kg}$. These are assumed to take up about

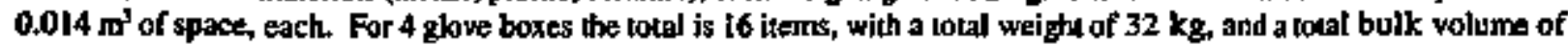
0.224.

\section{D.2.3 Workbenches}

The four workbenches in the ${ }^{14} \mathrm{C}$ facility have a total combined length of $15 \mathrm{~m}$ (Reference 1, pp 7-12). The faur bencikes are assumed to be $5.5 \mathrm{~m} 5.5 \mathrm{~m}, 3 \mathrm{~m}$ and $1 \mathrm{~m}$ long. Each bench is assumed to be $0.75 \mathrm{~m}$ deep (with a top work area of $11.25 \mathrm{~m}^{2}$ ) and $0.9 \mathrm{~m}$ high. Exch bench is constructed of latex-painted wood and has a plastic-taminaled top, assumed to be 0.0015875 - m-thick polycartionate. One of the workbenches has a stainless steel sink momted in it; the luto longer workbenches each have two glowe boxes seeting on thesth and the small bench has no perringent component mounted on it. These wotkbenches are assumped to have one drawer $0.1525 \mathrm{~m}$ deep and below that, a shelf a few centimeters above the tloor, with two doors. To simplify calculations, it is asstmed that each drawer and each set of cabinet doors in the 15-m-length of workbenches is 1 meits wide, and a vertical plywood panel supports the benches every 1 meter (a total of 16 panels).

Because of the proximity of the workbenches to radioactivity-containing components, all of the worktench materials are assumed to be radisactive. The surfaces are first vacuumed, wet-wiped, and thent paitted to fix surface contamination. The beacties are then eut into pieces, bagged, and placed in 208-liter duunts. The drums of aro compacted on-site, and sent offsite for superompaction. If the incineration option is used, the waste is sent off-site for inctneration, followed by fixation of the restluing astes into monofithic solids.

\section{Amount of Wood in the Workbenches}

Front and Back: $2 \times 0.9 \times 15 \times 0.01905$

Sides \& Support Panels: $16 \times 0.75 \times 0.9 \times 0.01905$

Bottom \& Top: $15 \times 3 \times 0.75 \times 0.01905$

Sides: $30 \times 0.75 \times 0.1524 \times 0.01905$

Back: $15 \times 0.1524 \times 1 \times 0.01905$

Total Voiume:

$$
\begin{aligned}
& =0.51435 \mathrm{~m}^{3} \\
& =0.20574 \mathrm{~m}^{3} \\
& =0.64294 \mathrm{~m}^{3} \\
& =0.06532 \mathrm{~m}^{3} \\
& =0.04355 \mathrm{~m}^{3} \\
& =1.47190 \mathrm{~m}^{3}
\end{aligned}
$$


Total Wetght (s.g. $=0.8$ )

$=1,178 \mathrm{~kg}$

Amount ot Polycarbomate Plastic on the Surfaces of the Workbenches

Volume: $15 \times 0.75 \times 0.0015875$

Weight (s.g. $=1.2)$

$$
\begin{aligned}
& =0.01786 \mathrm{~m}^{3} \\
& =21.4 \mathrm{ks} .
\end{aligned}
$$

The plastic laminate is not removed from the workbenches.

\section{Amount of Processtog Equipment on the Workbenches}

It is assumed that the workbenches were ased for radioactive counting equipment, which had to stay reasonably clean; for tools (agatn, assumed to be free of contanination) for making siral] new parts for the hoods and glove boxes; for temporary storage of nanradioastive materials; for overpacking the proxhacts (again expected to be a relatively clem aperation); and other similar uses. The conkaminated material below is to be bagged, losded into 208-liter drums, compacted on-site, and senl off-site for supercompaction before being sent for dispossal as LLW. The folkowing general type of equipmean is postulated to be present on the workbenches:

- Various hand tools including a vise, prinatily steel, weighing a lotal estimaled $12 \mathrm{~kg}$, with a total gross bulk valume estimated to be 0.008 .

- 2 signilicant itens of processing glassware, each weighing sbout $3 \mathrm{~kg}$. For the 2 glass items, the items would weigh about $6 \mathrm{~kg}$ and require an estimgied $0.04 \mathrm{~m}^{3}$ of total bulk space.

- 2 items of vatious materials (metals, plastic, ceranic), exch weighing about $2 \mathrm{~kg}$. For the 2 iterns, the total weight is estimated at $4 \mathrm{~kg}$, with an estimated total betlk volume of $0.004 \mathrm{~m}^{3}$.

\section{D.2.4 Vent Ducts}

The ${ }^{4} \mathrm{C}$ facility contaitns $16 \mathrm{~m}$ of cylindrical ductwork $0.2 \mathrm{~m}$ in dianeter and $14 \mathrm{~m}$ of rectangular doctwork $0.25 \mathrm{~m} \times 0.6 \mathrm{~m}$ in cross-section (Reference I, p. 9-9). The ductwork is assurned to be stainless steel sheet netal 0.0015875 in thick.

The ductwork is assurned to be radioactively contaminated internally and externally. The ductwork is vacurired and wetwiped where possible to remove the readily-removable contarination, then painted to minimize contamination during subsequent steps. The duct waske is cut into pieces that maximize the amount of material that can fri in 208-liter drums. The waste pieces are placed in plastic bags before being placed in the drustis. The waste-filled druths are then compacted on-stee and then shipped off-site for supercompaction before being disposed of as ILW.

\section{Amount of Materlal In the Ductwork}

Cylindrical Ductwork Volume Rectringulor Ductwork Volume

Total Volume Tolal Weighe

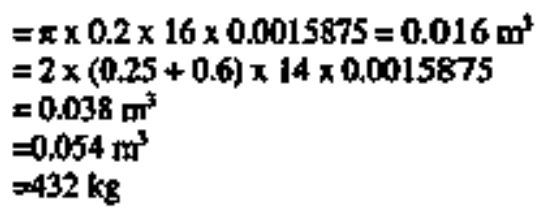




\title{
D.2.5 Cabinets
}

The "C facility cortains two cabtinets, each postulated to be constructed of 0.01905 m-thick latex-painted wood. The dimensions of each cabinet are assimed to be $0.762 \mathrm{~m}$ wide $\times 0.4572 \mathrm{~m}$ deep $\times 1.524 \mathrm{~m}$ high. Each cabinet is assumed to have two locking doors, and thee shelves plus the bottom inside shelf.

Both cabisets are given only mild decontamination by vacuuming and wel-wiping. The material is then painted and sectioned. The sectioned waste is then bagzed and placed in 208 -liter drums for on-site compaction. The drums are then shipped off-site for supercompaction. If the insineration option is used, the waste is sent off-site for incinerntion and soltdification of the ashes.

\author{
Amount of Materlal in Each Cablnet to be Disposed of as Waste \\ Front and Back $2 \times 0.762 \times 1.524 \times 0.01905$ \\ Two Sides: $2 \times 0.4572 \times 1.524 \times 0.01905$ \\ Top, Bottom, 3 Shelves: $5 \times 0.762 \times 0.4572 \times 0.01905$ \\ Total Volume \\ Total Volume for 2 Cabinets: \\ Total Weight tor 2 Cabinets $(\mathrm{s} . \mathrm{g} .=0.8)$

$$
\begin{aligned}
& =0.0442 \mathrm{~m}^{3} \\
& =0.0265 \mathrm{~m}^{3} \\
& =0.0332 \mathrm{~m}^{3} \\
& =0.1039 \mathrm{~m}^{3} \\
& =0.2078 \mathrm{~m}^{3} \\
& =166.24 \mathrm{~kg}
\end{aligned}
$$

\section{D.2.6 Frezer and Refrigerators}

The ${ }^{14} \mathrm{C}$ facility contains one freezer and two refrigerators, all posatlated to be upright tmits, with the sarte dimensions of $0.6096 \mathrm{~m} \times 0.6096 \mathrm{~m} \times 1.524 \mathrm{~mL}$. The three unils art assumed to be only mildly contaminated inside. But outside, the compressor, coils, fan, and other mechanisms are assumed to sufficiently contaiminated that it would not be reasonable to try to decontaminzte them to levels required for unrestricted use. Thus, they are assumed to be disposed of as radioactive waste with only minimal docontamination. It is assurmed that the freon (nox contsminated) will be removed on-site by a stubcontractor. The onits will then be vacuwned, wiped and painled, and then cut up and bagged into 208-liter drums for ou-site compacting. The units will then be shipped off-site for supercompacting before disposal as LLW. Sectioning will be done to effectively use the space in the dinus.

\section{Amouat of Matertial in the Three Uatts}

This is based on the gross charactetistics of conventional refiggerators and freezers. Each unit will caolain the refrigeration cooling system (copper, sted, other melals), some framework (mild steel), plastic inner and outer wal's separaled by fiberglass insulation, come plastic trays and glass and mild sceel shelves inside. The sectioned and pre-compacted volune of the three onits is assumed to be the same as when whole, or $3 \times 0.6096 \times 0.6096 \times 1.524=1.699 \mathrm{~m}^{3}$. The overall weight of each refrigerator or freezer unit is assumed to be $68 \mathrm{gg}$, for a total weight of $204 \mathrm{~kg}$.

\section{D.2.7 HEPA and Roughing FHIters}

The ' ${ }^{4} \mathrm{C}$ facility uses the ejpht FFPA and roughing filters duriting normal operation (Reference 1, p. 9-9), one each at the exhanst of each fume hood and glove box. No other HEPA or roughing filters are in the facility. It is postulated that the facility fitters had been replaced at the end of the operating period, and they will last throughout the lots decomrmissioning period. In addition, it is assumed that during the vacuuming actiwly of the components and the facility, 2 comrtiencial vacisam unit is leased that uses a roughing filter and a HEPA filter identical to those in the facility, and two sets of talters are used durlag vecruming, bringing the total to 10 sets. The filler removal is one of the last activities underaken during 
decommisstoging. Erch filter is sealed in a plastic bag during its removal. Each HEPA filler is $0.2 \mathrm{~m}$ io diameter and $0.2 \mathrm{~m}$ high (Reference 1. p. 9-9). The roughing filters are $0.2 \mathrm{~m}$ in diameter and $0.1 \mathrm{~m}$ high (Reference 1 , p. 9.9). It is assumed that the filters are comprised of shett-metal casing with pleated paper as the filter medium. It is postulated that the filers are bagged, placed in 208-jiter drums for on-site compaction, followed by shiprinent off-site for supercompaction before being packaged for disposel as LW.

\section{Amount of Matertals in the Fillers}

The bulk (rectangular) volume of the 10 HEPA fitters is $10 \times 0.2 \times 0.2 \times 0.2=0.08$ The overall weight of each HEPA filiter is assumed to be $5 \mathrm{~kg}$. Thus the cotal wejght of the $10 \mathrm{HEPA}$ filters is $50 \mathrm{~kg}$. The belk (rectangular) voleme of the 10 roughing tatlers is $10 \times 0.2 \times 0.2 \times 0.1=0.04 \mathrm{~m}^{3}$. The overall weight of each roughing tilter is assumed to be $2.5 \mathrm{~kg}$. Thus the tolat weight of the 10 roughing filters is $25 \mathrm{~kg}$.

\section{D.2.8 Sinks and Drains}

There is one single-bowl sink in the "C facility. The sink is mourted in one of the workenches. The sink is assumed to be 18-gage stainless steel (0.00i214 m thick) with inside dimensions of $0.635 \mathrm{~m}$ wide $\times 0.5588 \mathrm{~m}$ long $\times 0.3048 \mathrm{~m}$ deep, with overall dimensions of 0.8382 w wide $\times 0.5588$ in deep to allow for the flanges (Reference 2). The sink is ussed for hand washing and for rinsing laboratary glassware. Low levels of ndikactivity are discharged to the sanitary sewer via the sink (Reference 1, p. 7-12). Contamininted liquids are not purposely discharged to the sanizary sewer via the sink. Thus, it should have low leveis of radioactive contanination. The drain pipe is equivalent to a $2-m$ length of 0.1 -m-diameler pipe (Reference 1, p. 9-9).

The sink and jis associated walter faucel and intide drain ptpe are wiped down only, then removed and fant up in a way that uses up space efficiently in the 200-Iiter drum. The material is then placed in plastic bags by a pipejinter, asststed by a technician. The waste materials are cornpacted on-site, and superconipacted off-sile disposal as LLW.

\section{Amount of Sinindess Sted in the Sink}

The sink is assurned to weigh sbeut $12 \mathrm{~kg}$ and to require a balk wolume of an estinuled $0.113 \mathrm{~m}^{3}$.

\section{A mount of Bress in the Fixtare and Conpections}

The weight of the brass is estimated to be $3 \mathbf{~ k g}$, assuming a specific gravity for brass of 8.75 . The brass will occupy about 0.0283 in of bulk space.

\section{Amosat of Galvanized Stect in the Drain and P Trap}

This is equivalent to 2 meters of 0.1 -m-diameter pipe (Reference 1. p. 9.9), or an estimated $16.05 \mathrm{~kg} / \mathrm{m} \times 2 \mathrm{~m}=32.1 \mathrm{~kg}$. The bulk volume of the material is eslizsted to be $0.02 \mathrm{~m}^{3}$.

\section{D.2.9 Facility Ceiling}

The "C facility ceiling consists of $80 \mathrm{~m}^{2}$ of acoustically-treated fiberboard (Reference 1, p. 9-8) that is uspended (above which some piping and electrical witing is mounlect). The fikerboand is in panels that are typically $0.3 \mathrm{~m} \times 0.3 \mathrm{~m}$, or $0.3 \mathrm{~m} x$ $0.6 \mathrm{~m}$ Each pantel can be removed separately.

The fiberboard, postulated to be 0.0127 in thick, has a rough surface and many pores, so is Impractical to ty to decontaminate. The ceiling parels are linst vacumed end printed to fix uhe contamination, thes are removed for disposal as radivactive waste. The ceiling materials are broket op if necessary and bagged and tinserted into 208 -liter drums. The waste 
is then compacted onsite before being transported off-site for supercompaction and dispasal as LLW. If the incineration option is used, the resultant ash is fixated into a chanolithic solid. The specific gravity of the fiberboand is assumed to be 0.5 .

\section{Amonnt of Moterial in the Ceiling}

Total volume: $80 \mathrm{~m}^{2} \times 0.0127 \mathrm{~m}=1.016 \mathrm{~m}^{3}$

The estimated pre-compacted bulk valume is assunned to be twike the acural volume, or about $2.0 \mathrm{~m}^{3}$. The total weight is 508 kg.

\section{D.2.10 Facility Walls}

The $108 \mathrm{~m}^{2}$ of walls of the "C facility (Referenee $\mathrm{t}, \mathrm{p} .9-8$ ) are plastertaard (postulated o be 0.015875 $\mathrm{m}$ thick) painted with latex enartel. It is asstamed that the walls are deconlaninated 10 unrestricted use levels lo maintain the wall surfaces and to keep from contaninating the wall insulation and structural members behind the walls. The walls are first vactuurred, then wiped with wet rags and boushes. The decontaninating solution, a dilute squecus detergent, is applied sparingly to minirrize dripping. After wet-wiping, the walls are wiped with dry rags and alkswed to dry completely. For final decontaminations, strippable paint is applied brushed or colled on, altowed to dry, then stripped off with the contamination. Final hot spots are manually wet-wiped, or spot-painted again with strippabie paint. Only the maletials ustet for decontastination are assuned to become $L L W$. These are bagged and placed in 208 -liter drums.

\section{Amounts of Waste Materists Resulting from Decontaminating the Walls}

The estimites developed in Reference 1. p. E-30, tor the wastywipe operations seern reasonable for the decontamination procedures used in that study, bot in thts study, far less of the liquid decontamunating agent is assumed to be used, with part of the decontamination being done with strippable paint. Thus, the amount of rags, bnshes, and liquid wastes here are taken to be 1/3 of those in Reference J, with adjusiments for wall area The estimates of waste materials fmomdecontamination and the subsequent waste treatment are given below. Dispostion of the final wastes is discussed in each of the three subsets of waste categories below.

- 2 208-liter drums of wet rags, bnushes and contaminaled gloves and olher clothing (Reference 1) ssumed to be sent offsite for incineration, resulting in $t \hat{0} w$ to (about one drum) of ashes for fixation into a monolithic solid and disposal as LLW. Estianured weight of these wrstes before treatment is $40 \mathrm{~kg}$.

- 0.67208 -liter drums of aqueous decontamination solutions (assumed to have sinall amounts of detegents) and rinse solutions from washing/wiping decontantination, belore solidiffcation with an adsortent material. Eslimated weight of the wastes before solidifieation is $90 \mathrm{~kg}$. The adsorbed wastes are sent direcely for disposal as $\mathrm{L} L \mathrm{~W}$.

- 2 208-liter drums equivalent of removed strippsble patnl (assumed in this study) to be reduced to one drum after on-site compaction). Estimated weight of the LLW is $40 \mathrm{Kg}$. The wasle is compacted on-site, then sent to supercompaction for disposal as LLW.

\section{D.2.11 Facillty Floor}

The Iloors of the 'C facility (Reference 1, p. 9-9) consist of $80 \mathrm{~m}^{2}$ of asphalt tike (postralated to be $0.0015875 \mathrm{~m}$ thick) over plywood (postulated to be $0.01905 \mathrm{~m}$ thick). The specific gravity of the tiles is assumed to be 1.1 . The floor is postulated to 
be fyst vacuarmed and then painted to fix the remaining contamination. The tiles are removed manually, packaged in bags. and placed in 208-liter drunts as $L W$. The remaining hol spols in the wood sub-looring are cleaned by a small amount of straping or planing. The wood scrapings are bagged and placed in 208-liter drums for on-site compacting, followed by offsite supercompaction or incineration.

\section{Amount of Ekor Tlle Waste}

Total Volume of Floor Tiles: $80 \times 0.0015875 \quad=0.127 \mathrm{~m}^{3}$

Total Weight of Floor Tiles: 1 t00 $\times 0.127 \quad=140 \mathrm{~kg}$

The floor tiles are compacted on-site, sapercompacted off-site, and then sent far disposal as LLW.

\section{Amount of Wood Scraping Waste}

The amounl of wood scrapings removed as radioactive waste is difficult to estifrate. A number of the cracks between the files will have contaminaled wood that needs to be removed, probably to a depth of ahout $0.003 \mathrm{~m}$. The lotal amount of wood scrapings removed as radicactive waste is assumed to be $50 \mathrm{~kg}$. with an assumed bulk specific gravity of 0.4 , for a Eross volune before compaction of $0.125 \mathrm{~m}$.

\section{D.3 Reference Laboratory for the Manufacture of ${ }^{125}$ I-Labeled Compounds}

Detailed physical descriptions and decommissioning procedures for all the components and bui]ding surfaces of the trI laboratory that ate postulated to nequire removal and/or decontamination are given in Sections D.3.1 through D.3.11. Details of (I) plasning and preparation, (2) eskmated manpower requirertents, (3) waste management, msierials, and labor cosis, and (4) radiution dosages are presented in Table D,3a for the supercompaction option and in Table D.3b for the supercompaction option with incineration. An overall description of this laboratory is contained in Section 7.t.3 of Reference 1.

\section{D.3.1 Fume Hoods}

The ${ }^{12} \mathrm{I}$ facility contains four fume hoods, each measuring $1.5 \mathrm{~m}$ wide $\times 2.0 \mathrm{~m} \mathrm{high} \times 0.945 \mathrm{~m}$ deep. Each furre hood contains one glove box. Each hood is assumed to be framed extemally by mild steel $0.003175 \mathrm{~m}$ thick. Each glove box and forne hood is equipped with an attivated charcoal filter at its effluent exhaust. At the point where the ventilation air leaves the facility, a roughing fulter, a HFPA filler, and a chareosal filter are installed. Esch hood is equipped with an acrylic window 0.00635 thick. Inside each fume hood is a specially-designed giove box. Thus, each glove box must be removed before the respective fume hood can be remaved. The hood is assurned to rest on an enclosed stainless steel-based cabinet (Fig A.5-1, Reference 1). The support cabinet is assumed to have the sarne foot print as the fume hood but is only $0.9 \mathrm{~m}$ high.

Before the fume hoods are dismamled, the fnierior and exterior surfaces are first vacuutaed and wet-wiped, then dried and painled to fix comarnination. The hoods are then cut to sizes that allow the hood materials to be bagged and placed in 20B-Jiter drums in such a way that the materials can be neasonsbly compacted on-site, then superconpacted off-site.

\section{Amuat of Stainless Steel Upper Section}

Back: $1.5 \times 2.0$

Two sides: $2 \times 0.945 \times 2.0$

Floor and Top: $2 \times 1.5 \times 0.945$

Total Area

$$
\begin{aligned}
& =3.00 \mathrm{~m}^{2} \\
& =3.78 \mathrm{~m}^{2} \\
& =2.835 \mathrm{~m}^{2} \\
& =9.615 \mathrm{~m}^{2}
\end{aligned}
$$




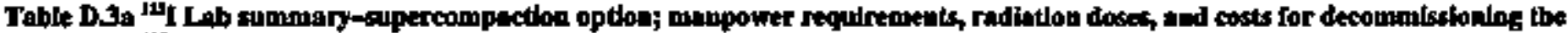

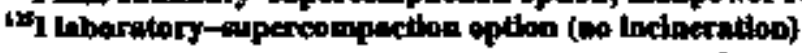

\begin{tabular}{|c|c|c|c|c|c|c|c|c|c|c|}
\hline \multirow[b]{2}{*}{ Operution or calerar } & \multirow{2}{*}{$\begin{array}{c}\text { Thes: } \\
\text { (dets) }\end{array}$} & \multicolumn{6}{|c|}{ Percosing } & \multirow{2}{*}{$\begin{array}{c}\text { Toth } \\
\text { pertiders }\end{array}$} & \multirow[b]{2}{*}{ Pasel-mits: } & \multirow{2}{*}{$\begin{array}{c}\text { Cenis } \\
\text { (Stas) }\end{array}$} \\
\hline & & Strenver & 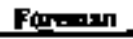 & Croltenen & H.P.Texh & Tech & Clank & & & \\
\hline \multicolumn{11}{|l|}{ Phnnis a preparation } \\
\hline Prepare documedulou & 15.0 & 7.5 & $\mathbf{1 5 . 0}$ & ـ & - & - & 7.5 & 300 & - & 9.9 \\
\hline Perkxn midogfeal sorvey & 3.5 & - & 3.5 & - & 7.0 & $\leftrightarrow$ & - & 105 & 213 & 3.7 \\
\hline Develop wort plup & 10.0 & 3.0 & 100 & - & $\mathbf{s . 0}$ & 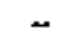 & 50 & 25.0 & $\stackrel{-}{*}$ & 23 \\
\hline subiakals & 2,5 & 12.5 & 205 & - & 12.0 & - & 125 & 65.5 & 2.13 & $21 . \%$ \\
\hline \multicolumn{11}{|l|}{ Decon:n'ssiontog } \\
\hline Pune boods & 48 & 24 & 40 & 1.1 & 2.4 & 81 & - & 18.1 & 0.09 & 6.7 \\
\hline Glove boxte & 14 & 0.7 & 13 & 0.4 & a.7 & 25 & .. & $\$ .6$ & 13.75 & 2.1 \\
\hline Worthenches & 3.0 & 15 & 2.1 & 1.0 & 1.5 & 41 & - & 101 & 002 & 3.8 \\
\hline Verdinets & 0.4 & 0.7 & 1.0 & 05 & 0.7 & 2.1 & $\leftrightarrow$ & 50 & 002 & 1.9 \\
\hline Crabets & 0.9 & 0.4 & 0.7 & $\mathbf{0 . 2}$ & 0.4 & 1,3 & - & 3.1 & 0.09 & 12 \\
\hline Fuestr end sefrigetratios & 0.5 & 02 & 0.4 & 0.1 & 0.2 & 0.8 & .. & 18 & 002 & 07 \\
\hline Fikes & 0.6 & 0.3 & 06 & - & 03 & 1.2 & - & 2.4 & 002 & 99 \\
\hline Sink and dring & 0.2 & 0.1 & 02 & $\mathbf{0 . 1}$ & 01 & 04 & - & 08 & 000 & 03 \\
\hline Cennt & 1.5 & 0.7 & 1.5 & $\sim$ & 0.7 & $\$ .0$ & $\leftrightarrow$ & 5.9 & 000 & 22 \\
\hline Walls & 2.6 & 1.3 . & 26 & $*$ & i.j & 32 & - & 104 & 0.10 & 1.8 \\
\hline Fkoms & 16 & 08 & 16 & $\therefore$ & 08 & 32 & - & 6.4 & 003 & 24 \\
\hline Subainis & 18.4 & 92 & IS. & 3.4 & 12 & 31.9 & $*$ & 66 & 14,15 & 25.9 \\
\hline \multicolumn{11}{|l|}{ Equipneox and tneterials cost } \\
\hline Connering vacuum cleuner & - & - & - & - & 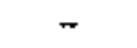 & - & - & 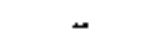 & - & 10 \\
\hline Conpector & - & - & - & - & - & r & - & .. & -. & 17.2 \\
\hline Small cooks had makrials & - & - & - & $*$ & - & 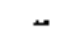 & - & - & - & as \\
\hline Lundy & 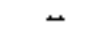 & - & - & - & - & - & - & - & - & 1.8 \\
\hline $\begin{array}{l}\text { Subtocils } \\
\text { Whtse manapement cogits }\end{array}$ & $*$ & - & - & - & $m$ & - & - & - & - & 220 \\
\hline Pactuging & - & - & .. & - & - & .. & - & - & - & 1.9 \\
\hline Supeceompactos & - & - & .- & - & - & 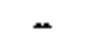 & - & - & - & 3.9 \\
\hline beineration & - & - & - & - & - & - & -- & - & - & 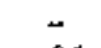 \\
\hline Tranporavod & 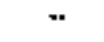 & - & - & 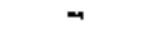 & - & $n$ & - & 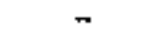 & + & 06 \\
\hline Disposol & 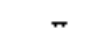 & 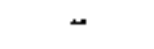 & - & 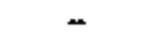 & 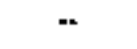 & - & - & 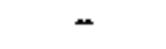 & - & 21.9 \\
\hline Salotets & - & - & - & - & - & - & - & $*$ & - & 28.3 \\
\hline 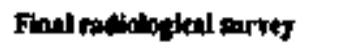 & 3.0 & 15 & 3.0 & $*$ & $\mathbf{6 0}$ & - & 3.0 & J3.5 & - & 42 \\
\hline Tats & 496 & 23.2 & $47 A$ & $\mathbf{3 . 4}$ & 272 & 31.5 & 155 & 1486 & 16.23 & $10 \mathrm{~s}$ \\
\hline 25\% Coar conxibgency & - & - & - & - & - & 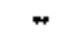 & - & $*$ & - & 25.8 \\
\hline 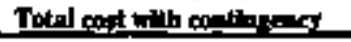 & $m$ & $=$ & $=$ & $=$ & - & $=$ & $=$ & - & - & 128.8 \\
\hline
\end{tabular}




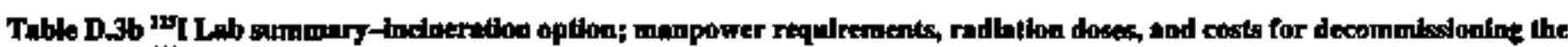

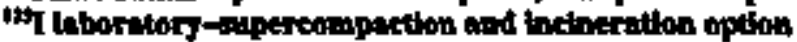

\begin{tabular}{|c|c|c|c|c|c|c|c|c|c|c|}
\hline \multirow[b]{2}{*}{ 0. } & \multirow{2}{*}{ Th=t } & \multicolumn{6}{|c|}{ Fersoganders } & \multirow{2}{*}{ 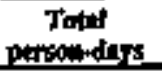 } & \multirow[b]{2}{*}{ 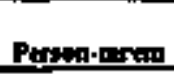 } & \multirow{2}{*}{$\begin{array}{l}\text { Conts } \\
\text { (t) ond }\end{array}$} \\
\hline & & Sopervion & Poxemin & Cnflewen. & H.P.,Tech & Terk & Clett & & & \\
\hline \multicolumn{11}{|l|}{ Phenics \& preperntion } \\
\hline Prepare docrinembition & 150 & 71 & 150 & - & - & - & 75 & 300 & - & 9.9 \\
\hline Peform ridotogical gurvey & 35 & - & 35 & - & 70 & - & -- & 105 & 213 & 3.7 \\
\hline Develop work plas. & tono & 50 & 100 & - & 50 & - & 50 & 250 & - & $\mathbf{B} 3$ \\
\hline Solpounls & 20.5 & 125 & 20.5 & $\boldsymbol{\sim}$ & 120 & $*$ & 12.5 & 6.5 & 2.13 & 21.9 \\
\hline \multicolumn{11}{|l|}{ Decononitsianting } \\
\hline Fume boods & 48 & 24 & 40 & I.1 & 2.4 & 0.1 & - & It.I & 009 & 6.7 \\
\hline Glave boura & 14 & 0.7 & 13 & 04 & 6.7 & 25 & - & 56 & $\$ 3.75$ & 2.1 \\
\hline Fontbenclu & 30 & 1.5 & 2.1 & 10 & 1.5 & 4,1 & - & $10 \mathrm{I}$ & 002 & 39 \\
\hline Vent ducts & 1.4 & 0.7 & 10 & 05 & 07 & 21 & - & 50 & 002 & 1.9 \\
\hline Cabives & 0.9 & 0.4 & 0.7 & 0.2 & 04 & 1.3 & - & 3.1 & 003 & 1.2 \\
\hline 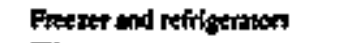 & 05 & 02 & 0.4 & 01 & 02 & 06 & - & 1.8 & 002 & 07 \\
\hline Fiker & 06 & 0.3 & 06 & - & 0.3 & 1.2 & 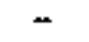 & 2.4 & 002 & 09 \\
\hline Sink and dnin & 0.2 & d.t & 02 & o.d & DI & 04 & - & 08 & $\mathbf{0 0 0}$ & 03 \\
\hline Celling & 15 & 0.7 & 1.5 & - & 07 & 30 & - & 5.9 & 006 & 2.3 \\
\hline Watts & 26 & 13 & 26 & $\leftrightarrow$ & 13 & 5.2 & - & 104 & 010 & 38 \\
\hline Floors & 16 & 08 & 16 & 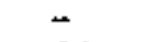 & 08 & 32 & - & 64 & 003 & 24 \\
\hline Sobletists & ISA & 9.2 & 159 & 3,4 & 9.2 & $31 s$ & $\bullet$ & $6 \mathbf{4}$ & 14.15 & 25.9 \\
\hline \multicolumn{11}{|l|}{ 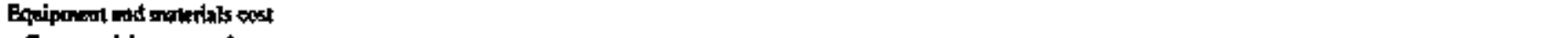 } \\
\hline 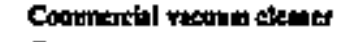 & - & - & - & - & - & 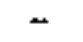 & - & + & $=$ & 30 \\
\hline Compactor & - & - & $\rightarrow$ & - & - & - & - & - & - & 172 \\
\hline Smatl coold add enditaly & $\sim$ & - & - & $=$ & - & -- & - & $*$ & - & 08 \\
\hline trmatry & - & $=$ & - & $*$ & - & - & - & - & - & 10 \\
\hline solvoduls & $\rightarrow$ & - & - & - & $*$ & - & -. & - & - & 22: \\
\hline \multicolumn{11}{|l|}{ Waste manisement costs } \\
\hline Peckpjug & 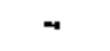 & - & 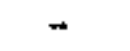 & - & - & - & $*$ & - & + & 19 \\
\hline Supereoupaction & - & - & $*$ & - & - & - & $\rightarrow$ & - & - & 2.8 \\
\hline Incinemation & 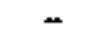 & $\leftrightarrow$ & - & - & 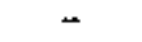 & - & - & -- & - & 113 \\
\hline Trimspontution & - & - & - & $\omega$ & $=$ & - & - & - & - & 05 \\
\hline Disporsl & - & - & - & $\cdot-$ & - & - & $\sim$ & $\sim$ & - & 178 \\
\hline Souneslats & - & - & 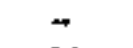 & 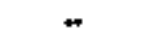 & + & $*$ & $*$ & $*$ & - & 34.6 \\
\hline 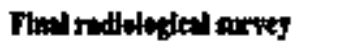 & 34 & 1.5 & 30 & - & $\mathbf{6}$ & - & $3 \mathbf{0}$ & 13.5 & - & $\mathbf{4 2}$ \\
\hline Totels & 49 & 23.2 & 47,4 & $\mathbf{3 A}$ & 27.2 & 31.9 & 159 & 148.6 & 16.28 & 109.4 \\
\hline 75\% Cost contingency & - & - & - & - & - & $\sim$ & - & - & - & 27.3 \\
\hline 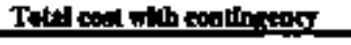 & 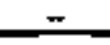 & - & $=$ & - & $=$ & 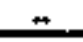 & $=$ & - & - & 135.7 \\
\hline
\end{tabular}


Appendix D

Total Volume; $0.003175 \times 9.615$

$=0.03053 \mathrm{~m}^{3}$

Total Volume for 4 Hoods

Total Weight for 4 Hoods

$=0.12212 \mathrm{~m}^{3}$

$=977 \mathrm{~kg}$

Amount of Stainless Steel in the Lower Cablnet

Back \& Froot: $2 \times 1.5 \times 0.90$

Two Sides: $2 \times 0.945 \times 0.9$

Bottom \& Top: $2 \times 1.5 \times 0.945$

$=2.700 \mathrm{~m}^{2}$

$=1.701 \mathrm{~m}^{1}$

$=2.835 \mathrm{~m}^{2}$

$=7,236 \mathrm{~m}^{2}$

$=0.02297 \mathrm{~m}^{3}$

Total Volumte $0.003175 \times 7.236$

Total Volume for 4 Hoods

$=0.09188 \mathrm{ut}^{3}$

Totsl Weight for 4 Hoods

$=184 \mathrm{~kg}$

Amount of Mild Stet in the Exterfor Frame

The frarte is assunied to be made of angle iron ( $0.0508 \mathrm{~m}$ by $0.04445 \mathrm{~m}$ by $0.0047625 \mathrm{~m}$ thick). The amount of mild steel is $4 \times 2.0 \mathrm{~m}$ for vertical members and $4 \times 1.5 \mathrm{~m}$ for horizontat members, for a total lengh of $14 \mathrm{~m}$. Total muld steel in ste furme hood frame is thas $14 \mathrm{~m} \times(0.0508+0.04445) \times 0.0047626=0.00635 t \mathrm{~m}$.

Total Volome for 4 Hoods

$=0.0254 \mathrm{~mm}^{\prime}$

Total Weight for 4 Hoods

$=203 \mathrm{~kg}$

Amount of Acrylic Plastic in the Window

The plastic is assemed to be $2.0 \mathrm{~m}$ high $\times 1.5 \mathrm{~m}$ wide $\times 0.00635 \mathrm{~m}$ shick, for a tolal volume of $0.01905 \mathrm{~m}^{3}$,

Total Volume for 4 Hoods

Total Weight for 4 Hoods (s.g. $=1.2$ )

$=0.0762 \mathrm{~m}^{3}$

$=91.4 \mathrm{~kg}$

\section{Amount of Processing Equtpuent}

There is very little space inside the fume hood for processing equipment because earh furte hood corthins a glove box that takes up most of the interior fume hood space. The following general type of centaminated equipmetis is postulated to be present in the fume hood. The equiprent is bagged and cornpacted on-site, super-compacted off-site, and ther disposed of as $L, W$

- 1 electric beating units, weighing abcut $7 \mathrm{~kg}$. This is assurned to take up abovt $0.03 \mathrm{~m}^{3}$ of space. For 4 fume hoods, the total is 4 electric heating units, with a total weight of $28 \mathrm{~kg}$ and a total bulk wolome of $0.12 \mathrm{~m}^{3}$.

- 2 significant items of processing glassware, exch weighing about $3 \mathrm{~kg}$ and taking up about $0.02 \mathrm{~m}^{3}$ of space. For 4 fume hoods, the sotal is 8 units of processing geasswart, with a total weight of $24 \mathrm{~kg}$ and a total bulk wohume of $0.16 \mathrm{~m}^{3}$.

- I item of various materials (metals, plastic, ceramic), weighting about $2 \mathrm{~kg}$. This is assumed to take up about $0.014 \mathrm{~m}^{3}$ of space. For $4 \mathrm{fu}$ (ume hoods the total is 4 itents, wìh a motal weight of $\mathrm{g} \mathrm{kg}$ and a total bulk volume of $0.056 \mathrm{~m}^{3}$. 


\section{D.3.2 Glove Boxes}

Each plove box in the 13 I facility is $1.2 \mathrm{~m}$ wide $\times 0.6 \mathrm{~m}$ high $\times 0.6 \mathrm{~m}$ deep (Reference $], \mathrm{p} 7 \cdot$ [5). Each glove box is constnuctod encirely of acrylic phastic, which is assumed to be 0.00635 m thick. Each glove box vents to its respective fume hood through a chaseal filter. As with the glove boxes in the other facilities, in the glove box front are assumed to be two 0.2-m-diatieter circular openings for neoprene plastic working gloves, in a vericai panel (acrylic plastic in this facility) that is $0.25 \mathrm{~m}$ high. Above this panel, the front of the glove box is assumed to slope backward at an angle of about 40 degrees. Al one end of the glove box is assumed to be an acrylic plastic atrifock for the insertion of equipment and material into the glove box. Airlock dimensions are $0.3 \mathrm{~m}$ high $\times 0.2 \mathrm{~m}$ wide $\times 0.2 \mathrm{~m}$ deep (Reference $1, p$. A.33). One acrylic air lock dorr is accessibte from onside the glove bax, and one is accessible from the inside of the box through the use of glove parts. Standard electrical receplacles are located ou the inside of the glove box, with power controlled by swilches mounted oetside on a service prnel tbove the glove box. Each glow box is situing in its respective fume hood, which in tum ts sitting on fis vespective sliniless ateel cabinet, described above in tiem 1.

Before the glove boxes are disnantled, the interior and exterior surfaces are vacumed and wash-wiped, then painted to fix contarmination. The glove boxes are then cut to sizes that aliow the bagged glove box malerials to effectively fitl a 208-titer drum for compaction on-sile. The drums are then sent oft-site for supercompaction and subseguent dispassl as LUW. The acrylic plastic and the equipment iaside the glove box are segregated into drums, each with one of these categories of materials.

\section{Amount of Acrilic Plastic in the Glove Box and Acress Air Loek}

Front \& Back $2 \times 1.2 \times 0.6 \times 0.00635$

2 Sides: $2 \times 0.6 \times 0.6 \times 0.00635$

Top: $0.9 \times 0.3 \times 0.00635$

Lower Fune Pancli: $0.25 \times 0.9 \times 0.00635$

Air Lock $(2 \times 0.3 \times 0.2+2 \times 0.2 \times 0.2) \times 0.00635$

Total Volume

Tocal Volume for 4 Glove Boxes

Total Weight for 4 Glove Boxes $(8 . z .=1.2)$ :

$$
\begin{aligned}
& =0.00914 \mathrm{~m}^{3} \\
& =0.00457 \mathrm{mt}^{3} \\
& =0.00171 \mathrm{~mm}^{3} \\
& =0.00143 \mathrm{~m}^{3} \\
& =0.00127 \mathrm{~m}^{3} \\
& =0.01813 \mathrm{~m}^{3} \\
& =0.07252 \mathrm{~m}^{3} \\
& =87 \mathrm{~kg}
\end{aligned}
$$

Ampunt of Processing Equipment in eact Clove Box

The following genersi type of contaninated equipment is postulated to be present in the glove box. The malerial is bagged. corrpurted on-fite, cupercompacted off-site, and disposed of as $L W W$.

- 2 electric heating units, exch weighing about $7 \mathrm{~kg}$ These are assunted to take up about $0.03 \mathrm{~m}^{3}$. For 4 glove boxes, the total is 8 electric heating tnits, with a total weigkt of $56 \mathrm{~kg}$ and a total bulk volurre of $0.024 \mathrm{mr}$.

- 8 signilicant items of processing glassware, each weighing abou $3 \mathrm{~kg}$. These are assumed to take up about $0.02 \mathrm{~m}^{3}$, each. For 4 glove boxes, the total is 32 iters of processing glassware, with a tobal weight of $96 \mathrm{~kg}$ and a total bulk wolane of $0.64 \mathrm{nn}^{*}$.

- 6 itens of vadious materials (metals, plastic, cerrmic), each weighing about $2 \mathrm{~kg}$. These are assumed to take up abont $0.014 \mathrm{~m}$, each. For 4 glove boxes, the total is $24 \mathrm{jtems}$ of varions materials, with a tocal weight of $48 \mathrm{~kg}$ and a total bolk volume of $0.34 \mathrm{~m}^{3}$. 


\section{D.3.3 Workbenches}

The two worthenches in the 12I facility have a 1oxal conbined length of $8 \mathrm{~m}$ (Reference 1. pp. 7-14 and 7-15). One is assumed to be $5 \mathrm{~m}$ long. the other, $3 \mathrm{~m} \mathrm{kng}$. The workbenches are assumed to be $0.75 \mathrm{~m}$ deep and $0.5 \mathrm{~m}$ high. The benches are constructed of painted mild sleel and have a slainless steel kop, assunted to be $0.003175 \mathrm{~m}$ thick. The longer bench has a staibless steet sink coounted in it; the small bencls has no perrmarient component qounted on it. These benches are assumed Wh have one drawer that is 0.1525 m deep and below tha, a shelf a few centimeters above the floor, wilh 2 doors. To simplify caleulations, it is assturned that each drawer and each set of cabinet doors in the 8-m-length of wotkbenches is $1 \mathrm{~m}$ wide. and a vertical steel panel supports the benches every $1 \mathrm{~m}$ (a total of 16 panels).

Because of the proximity of the workbenches to radioactivity-containing components, all of the workbench materials are assumed to be radioactive. The surfaces are vacumed and painted before being cut up itto pieces sized to effectively til] 201-liter drums. These droms of bogged materials are compacied on-site, and then sent off-site for supereompaction and burial as LLW.

\section{A mount of Pointed Mild Steet}

Back \& From: $2 \times 0.9 \times 8$

$$
\begin{aligned}
& =14.4 \mathrm{~m}^{2} \\
& =6.075 \mathrm{~m}^{2} \\
& \begin{array}{ll}
\text { Boltom, Shelf \& Drawter Botiors: } 8 \times 3 \times 0.75 & =18 \mathrm{~m}^{2} \\
\text { Drawer Sides: } 8 \times 0.75 \times 0.1524 \times 2 & =1.8288 \mathrm{~m}^{2}
\end{array} \\
& =41.523 \mathrm{~m}^{2} \\
& =0.0659 \mathrm{~m}^{3} \\
& =\$ 27 \mathrm{~kg}
\end{aligned}
$$$$
\text { Backs of } 8 \text { Drawers: } 8 \times 0.1524 \times 1 \quad=1.2192 \mathrm{~m}^{2}
$$$$
\text { Tolal Area }
$$$$
\text { Total Volume (Assuming } 0.0015875 \mathrm{~m} \text { thickress) }
$$

Amount of Stalmless Steel on the Surfaces of the Workbenches

Area $=8 \times 0.75=6 \mathrm{~m}^{2}$. Assuming this material is $0.003175 \mathrm{~m}$ thick and has a specific gravity of 8.0 , the volume of staintess steel is $0.01905 \mathrm{~m}^{3}$. and the weight is $152 \mathrm{~kg}$.

\section{Amount of Processing Equipment on the Worthenches}

In is asfumed that the workbenches were used for radioactive counting equipment, which had to stay clean; for tools (again, assumed to be free of contanination) for making small new parts for the hoods and glove boxes; for temporary storage of nonsdioactive materials; for overpacking the products (again, expected it be a relatively ciean operation); and other similar uses. The following genteral type of concarninaled equipment is postulated to be present on the workbenchess

- Various hand tools, primarily steel, weighing a lotal estimated $6 \mathrm{~kg}$. with a tolal gross bulk volume estimated to be $0.004 \mathrm{mr}^{3}$.

- 2 sigaificant ftems of processing glassware, each weighing about $3 \mathrm{~kg}$. For the 2 glass items, the items would weigh about $6 \mathrm{~kg}$ and would requtse an estimated $0.0400 \mathrm{~m}^{2}$ of tobal bolk space.

- 2 itenss of various materials (metals, plastic, ceramic), cact weighing 2 bout $2 \mathrm{~kg}$. For the 2 various itents, the tolat weight is estimated at $4 \mathrm{~kg}$, with an estimated total bulk volume of $0.004 \mathrm{~m}^{3}$. 


\section{D.3.4 Venl Ducts}

The ${ }^{12} \mathrm{I}$ facitily contains $8 \mathrm{~m}$ of cylindrical ductwork 0.2 meters in diarneter and $10 \mathrm{~m}$ of rectangular duct work $0.25 \mathrm{mx}$ $0.6 \mathrm{~m}$ in moss-section (Reference J, p, 9-9). The ductwork is assurred to be stainless steel sheet metal $0.0015875 \mathrm{~m}$ thick.

The dwetwork is assumed to be radioactively contaninated internally and externally. The dixctwork is vacuumed and weswiped where possible to remove the readily-remowable contamination, then painted to minimize contamination during stubsequert steps. The duct waste is cut into pieces that maximuize the amounl of materal that can fit in 208 - اuter drums. The waste piects are placed in plastic bags before being plactd in the drums. The waste-filled drums are then compacted on-site and then shipped off-site for supercompaction before being sent to dispossal as LLW.

\section{Amount of Materind in the Ductwork}

\begin{tabular}{|c|c|}
\hline $\begin{array}{l}\text { Cylindrical Du } \\
\text { Rectangular D }\end{array}$ & $\begin{array}{l}=0.00798 \mathrm{mt} \\
015875\end{array}$ \\
\hline $\begin{array}{l}\text { Totaf Volume } \\
\text { Total Wetght }\end{array}$ & $\begin{array}{l}=0.027 \mathrm{~m}^{\mathrm{J}} \\
=0.03498 \mathrm{~m}^{3} \\
=280 \mathrm{~kg}\end{array}$ \\
\hline
\end{tabular}

\section{D.3.5 Cabinets and Shelr Unit}

The cabinet in the "21 facility is skel (assumed to be paimted) with a glass panel (Reference 1, p. 9-11). The cabinel is assumad to have two locking doors (each one assumed to bave a glass panei) and three shelves plus the botiom inside shelf. The cabinet is astumed to be $0.762 \mathrm{~m}$ wide $x 0.60 \% \mathrm{~m}$ deep $\times 1.524 \mathrm{~m}$ high. The glass panel in each dnor is assurned to be $0.254 \mathrm{~m}$ wide $\times 1.27 \mathrm{~m}$ high $\times 0.00635 \mathrm{~m}$ thick. The steel shelves have $\mathrm{k}$ totol surface area of $4.5 \mathrm{~m}^{2}$. There are assumed to be six sbelves (ixcluding the top) in a beok-case type of unt thel is 1.5 m wide $\times 0.5 \mathrm{~m}$ deep $\times 2 \mathrm{~m}$ high, with steel tha1 is assumed to be 0.001588 m thick.

The cabinet and shelf unit are given only mild decontamination by vacuurining and wel-wiping. The units are then painted and sectioned. The sectioned waste is then bagged and placed in 208-liter firims for on-site compaction. Following compaction, the drutes are shipped oft-site for supercompaction before being sent to disposal as LLW.

\section{Amount of Pyinted Mud Sted in the Ceblnet}

Front \& Back: $2 \times 0.762 \times 1.524$

Windaws: $2 \times 0.254 \times 1.27$

Front \& Back minus Windows

Top, Botlom, 3 Shalves: $5 \times 0.762 \times 0.6096$

Total Area

Total Volome; $4 \times 0.00158$ s

Total Weight

\section{Amount of Gless in Cabtnet Doors}

Arga (from a, above)

Volume: $0.6452 \times 0.00635$

Weight (s.t. $=2.2$ )

$$
\begin{aligned}
& =2.3226 \mathrm{~m}^{2} \\
& =0.6452 \mathrm{~m}^{2} \\
& =1.6774 \mathrm{~m}^{2} \\
& =2.3226 \mathrm{~m}^{2} \\
& =4.0000 \mathrm{~m}^{2} \\
& =0.00635 \mathrm{~m}^{3} \\
& =50.8 \mathrm{Kg} \\
& = \\
& =0.6452 \mathrm{~m}^{2} \\
& =0.00410 \mathrm{~m}^{3} \\
& =9 \mathrm{~kg}
\end{aligned}
$$


Appendix D

Amount of Palnted Mild Steel in the Sheif Unit

Sides: $2 \times 0.5 \times 2$

Back: $1.5 \times 2$

Shelves \& Top: $6 \times 1.5 \times 0.5$

Total Ares

Total Volume: $9.5 \times 0.001588$

Total Weight

$$
\begin{aligned}
& =2 \mathrm{~m}^{2} \\
& =3 \mathrm{~m}^{2} \\
& =4.5 \mathrm{~m}^{2} \\
& =9.5 \mathrm{~m}^{2} \\
& =0.01509 \mathrm{~m}^{3} \\
& =120.7 \mathrm{~kg}
\end{aligned}
$$

\section{D.3.6 Refrigerator}

The ${ }^{22}$ I facility contrins one refrigerator, postutated to be an upright unit, measuring $0.6096 \mathrm{~m} \times 0.6096 \mathrm{~m} \times 1.524 \mathrm{~m}$ The refitgeralor is assumed to be only mildly contaninated inside. But outside, the compressor, coils, fan, and ather mecharisms are assumed to be sulficicolly contaminated that it would not be reasonable to try to decontaminate them lo [ave]s required for unrestricted use. Thus, they are assumed to be disposed of as radioactive waste with only minimat decostamination. It is assumed that the freon (not contaminated) will be removed on-site by a subcontraxtor. The refrigeraior will then be vacuumed, wiped and painted, and then cut up and bagged into 208-liter drums for on-sile compacting. The refrigerator wilt then be shipped off-site for supercormpacting before disposal as LLW. Sectioning will be done to effecively use the space in the dnums.

\section{Amount of Materis}

This is based on the gross characteristics of a conventional refrigerator. The refigerator will contain the refigeration cooling syscem (copper, steel, other metals), some framework (mild steel), plastic inner and outer walls separted by fibesglass insulation, some plastje trays and gless and mild sleel sheives inside. The sectioned and pre-compacted volume of the unit is assumed to be the same as when whote, or $0.6096 \times 0.6096 \times 1.524=0.566 \mathrm{mr}^{3}$. The weight of the refrigerator is $68 \mathrm{~kg}$.

\section{D.3.7 Filters}

The ${ }^{12}$ I facility has four sroll, round roughing filters and four smalt, round HEPA filters at the extsaust of each furse hood (4); one charcosl filter locaxed at the exhauss of each glove box (4) and each fume bood (4); and one Larger HEPA, one larger roughing filter, and one lagger tharcoal filter at the exhausl pienum of the facility. Each glave box vents inlo its respective furne hood through an ectivated charcoll filter, and each fumo hood vents to the facility exhaust vernilation system through arother activated charcoal fitter is well as through a HEPA and mughing filter. A bank of a (farger) roughing filter, a (larger) HEPA fitter, and anothtr charcoal filter (assumed to also be targer) is located in the ventilation ductwork as it leaves the facility (Reterence 1, pp. 7-15, 9-11). The latter set of fifters must have aboul 4 tiunes the capacity of each of the other filiers and the smaller roond activated charcol filters, and these is one larger filter to achieve the needed capacity. In addition, two sets of the smaller soughing-HEPA filters are assumbed to be used in the vacuuming during the decomrnis-

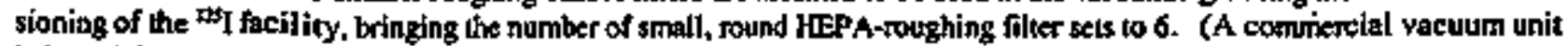
is leased that uses a roughing fitler and a HEPA fiher idemieal to those tin the facilliy for the decorrmissionjag vacuunting.) Thus, the total number of filers from decommissioning this facility is 6 round roughing filters, 6 tound HEPA filters. 8 round activend tharcoal filters, and I larger HEPA, I larger roughing, and I larger activated charcoal filter. It is poswlated that the facilily filters had been replaced at the end of the operating period, and they will last throughout the wat decomnissioning period. The filter removal from the total ventilation system is onte of the last activilies undertaken during deconvissioning.

Each filter is bagged with 2 plastic bag and seaked during its removal. The dimensions of the round HEPA and charcoal filters (Reference 1. p. 9-11) are $0.2 \mathrm{~m}$ in diameler $\times 0.2 \mathrm{~m} \mathrm{high}$. The larger, rextsangular filters at the facility exhaust are 0.25 $\mathrm{mx} 0.6 \mathrm{~m} \times 0.3 \mathrm{~m}$. It is assumed that all the filters are comprised of sheet-metal casing, and the HEPA and roughing filters 
use pleated paper as the fitter mediurn. It is assumed that the activated charcoal filters are comprised of activated charcoal granules within a stainless steel sheet-metsl casing. It is postutated that the charcoal filters are bagged out and placed in 208liter drums for compecting on-site, fallowed by direct shipnent as LWW 10 a dtsposal facility. It is postalated that the HEPA

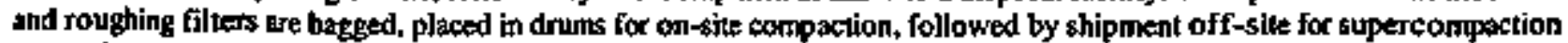
before being packaged far disposal as LLW.

\section{Amount of Materials in the Smoll, Round HEPA Filters}

The overalt weight of tach HEXA filter is assumed to be $5 \mathrm{~kg}$. The estimated weight of the 6 small, romend HEPA filters is thus $30 \mathrm{~kg}$. The bulk (rectangular) volume of the 6 small, round filters is $6 \times 0.2 \times 0.2 \times 0.2$, or $0.0 .048 \mathrm{~m}^{3}$.

\section{Amount of Meterials in the Large, Rectangular KEPA Flter}

The overall weight of the large HEPA tilter is assumed $\mathrm{k}$ be $12 \mathrm{~kg}$. The bolk volume of the large, rectangular filter is 0.25 $\times 0.6 \times 0.3,050.0450 \mathrm{~m}^{3}$.

\section{Amounl of Materials th the Sond, Round Rooghing Filters}

The overall weight of each roughing filter is assansed to be $25 \mathrm{~kg}$. The eslimated weight of the $6 \mathrm{small}$, round roughing filkers is thus $15 \mathrm{~kg}$. The bulk (rectangular) volane of the 6 small, round filters is $6 \times 0.2 \times 0.2 \times 0.1$, or $0.024 \mathrm{~m}^{3}$.

\section{Amount of Materials in the Larye, Rectangular Roughtwg Folter}

The overall weight of the large roughing filter is assumed to be $6 \mathrm{~kg}$. The butk volume of the large, rectangular filter is $0.25 \times 0.6 \times 0.15$, or $0.0225 \pi^{3}$.

\section{Amouat of Materials in the Small, Round, Charcoal Fillers}

The volume of activated charcoal per filter is estimated at $\pi / 4 \times 0.2 \times 0.2 \times 0.2$, or $0.00628 \mathrm{~m}^{3}$. At a specific gravity of $480 \mathrm{~kg}^{\prime} \mathrm{m}^{3}$, the charcoal in one filler weighs $0.00628 \times 480$, or $3.0 \mathrm{~kg}$. The staintess steel housing, assumed to be 0.001588 meters thick, has a volume of $\pi \times 0.2 \times 0.2 \times 0.001588,00.00020 \mathrm{~m}^{3}$, and weighs an escimaled $1.6 \mathrm{~kg}$. The total weight of a smalt, nound charcoal filter is then $3.0+1.6, \mathrm{or} 4.6 \mathrm{~kg}$. The total weight of $8 \mathrm{small}$, round activated charcosl fillers is $37 \mathrm{~kg}$, and the tolal (noclangular equivalent) volume is $0.064 \mathrm{~m}^{5}$.

\section{Atwount of Materinls in the Iarae, Roctangular Charenol Filter}

The wotume of activated charcosl per filter is estimated at $0.25 \times 0.6 \times 0.3$, or $0.045 \mathrm{~m}^{3}$. At a \$pecific gravity $480 \mathrm{~kg} / \mathrm{m}^{3}$, the charcosil in one large filter weighs $0.045 \times 480,0 \times 21.6 \mathrm{~kg}$. The stainless steel housing, assursed to be $0.00158 \mathrm{~B}$ metere thick, has an area of $4 \times 0,6 \times 0,3$, or $0.72 \mathrm{~m}^{2}$, and a volune or $0.72 \times 0.001588$ or $0.00114 \mathrm{pt}^{3}$, and weighs an estimated $9.1 \mathrm{~kg}$. The tous weight of the large, rectingular charcos filter is then $21.6+9.1$, of $30.7 \mathrm{~kg}$.

\section{D.3.8 Sink and Drain}

The ${ }^{2}$ I facilty has one sink and in-facility drain tine. The sink is mounted in one of the workbenches, near one etd. The sink is assurned to be 18-gage stainless steel (0.001214 m thick) with instde dianensions of $0.635 \mathrm{~m}$ wide $\times 0.5588 \mathrm{~m}$ high $\times 0.3048 \mathrm{~m}$ deep, with overall dimensions or $0.8382 \mathrm{~m}$ wide $\times 0.5588 \mathrm{~m}$ deep to al low for the flanges (Reference 2). The facility sink is used for personal cleanliness and for washing non-radionelive glassware. Liquid effluemt is discharged to a tank (2ssumed vo be outside) where it is heid for radioactive decay, monitored, and dituted as necessary before discharge to the sanitary sewer (Referetice 1.p. 7-15). Contaninated liquids aro bod purposely discharged to the sunitary sewer via the sink. Operationel aqueous waste liquids are nol dtecharged to the laboratory sink system, but are solidified with a setting 
Appendix D

material and shipped out as LLW during operalion. Operational organic waste liquids are absorbed on an absortent material that meets otisposal tacility requirentents, and are shipped out as a sotid LLW during operation (Reference I, p. 7-26).

The sints, fits arsocianed water funcet, and the timerier drain piping are wiped down, then removed, cut wo lo use up space in the 208-liter drum, ad bagged aut by a pipefitter assisted by a technician. The waste materials are compacted on-sjite and superconpacted off-site for dispostal as LI.W.

Amount of Stuinkess Strel in the Slnk

The sink is assunted to weigh about $12 \mathrm{~kg}$ and to require a buik volume of an estimated $0.113 \mathrm{~m}^{3}$.

\section{Amount of Brass in the Fixture and Connections}

The weight of the brass is estimated to be $3 \mathrm{~kg}$, assuming a specific gavity for brass of 8.75 . The brass will occupy alout $0.0283 \mathrm{~m}^{3}$ of bulk space.

Amount of Gakrantbed Steel in the Drvid and P Trap

This is equivalent $105 \mathrm{~m}$ of 0.1 -m-diameter pipe (Reference 1, p. 2-9), or an estimated $16.05 \mathrm{~kg} / \mathrm{m} \times 5 \mathrm{~m}=80.3 \mathrm{~kg}$. The bulk volume of the material is estimated to be $0.05 \mathrm{~m}^{3}$.

\section{D.3.9 Factlity Celling}

The ${ }^{12}$ I facility' $48 \mathrm{~m}^{2}$ ceiling is concrete seated with epoxy paint (Reference 1. p. 7-15). The ceiling is to be decontaquimated to untestricted levels. Becaust the facility ceiling is a rigid concrete structurc, decontanination is done in way to minisutze destruction of any significunt prat of the structure and its bighy chemically-resistant ceiling covering of epoxy paint.

The ceillng is first vacuurned, then wiped with wet rags and brushes. The deconopminating solution, a dilute aqueous deterzent, is applied sparingly to misimize dripping. Afte wet-wiping, the ceiling is wiped with dry ags and allowed to dry completely. Fintal decantarnination is by use of a strippable paint that is applied wish brushes or collers, allawed to dry, then stripped off with the contained contamination. Final hot spots are manuslty wet-wiped ther dry-wiped. Only materials used for decontamintion are assumed is becomo ILW. Disposition of esch type of waste is identified below.

\section{Amount of Weste Materials Reselting from Decoutaminaling the Ceiling}

The estinates developed in Reference 1. p. E-30 for the wash/wipe operations seen reasonable for the decontamination procectures used in that study, bat in this study, much less liquid decontaminating ageax is used, and part of the decontamination is done with strippable paint. Thus, the amount of rags and brushes, etce, and liquid wastes here is laken to be $1 / 3$ of that in Reference 1, with adjustments for surface area. The estimotes of waste materials from decontamination and the subsequent waste treatment ante giwen below. Disposition of the finsl wastes is discussed in each of the lhree subsets of waste calegories below.

- 1.33 208-liker drums of wet rigs, brushes and contaminated gloves and other clolhing (Reference 1). These are assunted to be conpected on-site, sent off-sile for supercompaction and WW disposal. tf the Incineration option is used, the waste is incinerated off-sile, with the ashes fixed into a monolithss sold, and disposed of as L.LW. Estimated weight of these wastes before trealment is $29 \mathrm{~kg}$. 
- 0.33208 -liter dnums of aqueous decontamination solution (assumed to have small amounts of detergents) and rinse solunions from wet/wiping decontamination, before solidification with an adsontent maltrial. Estimated weight of the wasle before solidification is $45 \mathrm{~kg}$. The adsorted waste is sent direclly for LLWW disposal.

- 1 208-liter drem equivalent of remeved strippable painl (assumed in this sudy) to be reduced to one-half drum after onsite compsction. Estimated weight of the waste is $20 \mathrm{~kg}$. The waste is sent of $f$-site for supercormpation before being disposed as LLW.

\section{D.3.10 Facility Walls}

The ${ }^{12}$ I faciliy's walts $\left(84 \mathrm{tm}^{7}\right)$ are concrete staled with epoxy paint (Reference $1, \mathrm{p} .9 .11$ ). The walls are to be decomaminated to unrestricted leveis. Because the facility walls are rigid concrete structures, decontarnination is done in ways to minimize destruction of any significant part of the structures andi their highly chernically-resistant epoxy paint coverting.

The walls are first vacuumed, then wiped with wet rags and brushes. The decomtaminating solution, a dilute aqueous detergent, is applied sparingly to ruinimize dripping. After wet-wiping, the walls are wiped wth dry rags and allowed to dry completely. Final decontamination is by use of a strippable paint that is applied with brushes ar rolkets, aftowed to dry, then slripped off with the contained contamination. Final hot spets are manually wet-wiped then try-wiped. Only materials used for decontaninaxion are assumed to become $L W$. Disposition of each type of wasle is identified below.

\section{Amount of Waste Materlats Resulting from Decontarnlaating the Wails}

The estimales developed in Reference l, page E-30, tor the washtwipe operations seent reasonable for the decontamination procectures used in that study, but in this study, much less lioguid deconkiminating agens is used, and pert of the decontamination is done with strippable paint. Thes, the antount of rags and broshes, etc., and liquid wastes here is taken to be $1 / 3$ of that in Reference 1, with adjusiments for surface ares. The estimates of waste materiats from decontamiration and the subsequent waste treaterent are given below. Disposition of the final wastes is discussed in each of the three subsels of waste categories below.

- 2.33208 -liter drums of wes rags, brushes and contarninated gloves and ocher clothing (Reference 1). These are assumed to be compacted on-site, sert off-site for stupercompaction and LLW disposal. If the incineration option is used, the waste is incinerated off-site, with ate ashes fjxed into a monolithic solid, and disposed of as LLW. Estimated weight of these wastes $1650 \mathrm{~kg}$.

- 0.67208 -liter drums of aqueous decontarnosxion solution (assumed to have small arnounts of detergents) and rinse solulions from wev/wiping decontamination, before solidification with an adsorbent materiat. Estinaled weight of the waste beforc solidification is $90 \mathrm{~kg}$. The adsophed moterial is sent directly for disposal as LLW.

- 1.33208 -liter drams rentoved strippsble paint (assumed in this study) to be compacied on-site. Estimated weight of the waste is $40 \mathrm{~kg}$. which is assumed to be compacted on-site, supercompacted off-site, and sent for disposal as LLW.

\section{D.3.11 Facility Floor}

The floors of the "II facility cootann $48 \mathrm{~m}^{2}$ of asphalt tike (postulated to be $0.001588 \mathrm{~m}$ thick) over concrete (Reference 1 , p. 9-1). The floor is postulated to be first vacuumed and then painied to fix the remaining contamination. All tiles are postulated to be removed tannally and packaged in plastic bags, then compacted on-sile, superconquacted off-site, and disposed of as $L \perp W$. The remaining hot spots in the concrese flooring are postulated to be cleaned by a screall arrount of scabbling, followed by re-vacusuning the entine floor sturiace. 
Appendix D

Amount of Waste Materlals Resolting from Removing Floor Tiles

The total walume of floor tites $=48 \times 0.001588=0.0762 \mathrm{~m}$. Assuming a specific gavity of 1.1 , the asphall tiles would weigh an estimaled $84 \mathrm{~kg}$. The floor liles are compacted on-sile, supercompacted off-síte, and then seat for disposal as LLW.

\section{Amount of Coparete Flooring Removed}

It is postulated that about $10 \%$ of the concrete area beiow the asphalt tiles will have become contarinated to a depth of $0.0127 \mathrm{~m}$. The total amount of concrete rubbte and dest removed as rafioactive waste is thus $48 \times 0.1 \times 0.0127=0.061 \mathrm{~m}$. Assuming the effective density of the dust is $60 \%$ of the theoretical specific gravity of conkrete $(2.5)$, the volume is $0.061 \% 0.6=0.102 \mathrm{mr}^{3}$. The weight is estimated to be $2500 \times 0.061=153 \mathrm{~kg}$. The conkrete rubble and dast are postulared to be bagged and drummed for efficient use of the drum space, foliowed by on-site compaction before being sent for disposal as LW.

\section{D.4 Reference Laboratory for the Manufacture of ${ }^{137} \mathrm{Cs}$ Sealed Sources}

Detailed physical deseriptions and decormuissioning procedtries for all the components and building surfaces of the ${ }^{137} \mathrm{Cs}$ laboratory that are postulated to require renowal and or decontamination are given in Sections D,4,I through D.4.11. Details of (1) planning and preparation, (2) estambied manpower requirements, (3) waste managerrent, materials, and labor costs, and (4) ratiation doseges are presented in Table D.4a for the supereompacion option and in Table D.4b for the stpereompaction option with incineration. An overall description of this taborslocy is contained in Section 7.14 of Reference I.

\section{D.4.1 Fume Foods}

The ${ }^{134} \mathrm{Cs}$ farility contains two furse hoods, each $1.5 \mathrm{~m}$ wide $\times 2.0 \mathrm{~m}$ high $\times 0.945 \mathrm{~m}$ deep. Each hood is assumed to be framed externally by mikt skel $0.003175 \mathrm{~m}$ thick and ts equipped with an acrylic wimflow $0.00635 \mathrm{~m}$ thick. Each hood is imrnediately adjacent to a small hot cell, and one side of the hood has a opening to sccommodate the sliding-door operting in the hot cell wo the hood. The hood is assumed to rest on an enclosed stainless stee)-based cabinet (Reference 1, p. A-30). The support cabinet is assumed to have the same foot print as the fume hood bot is only $0.9 \mathrm{~m}$ high.

Before the fume hoods are dismentled, the interior and exterior surfaces are vacuumed and wet-wiped, and then painted to fix contamitation. The hoods are then cut to sizes that allow the hood materials to be bagged and go into 208-liter drums in such a way that the materials car: be reasonably compacted on-site, then supercompacted off-site. 
Table B.4a ${ }^{15} \mathrm{Cs}$ L.Lb summary-supercompacilon option; manpower requirements, radtotion doses, and costs for decommissionimg the

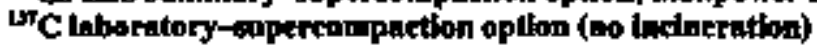

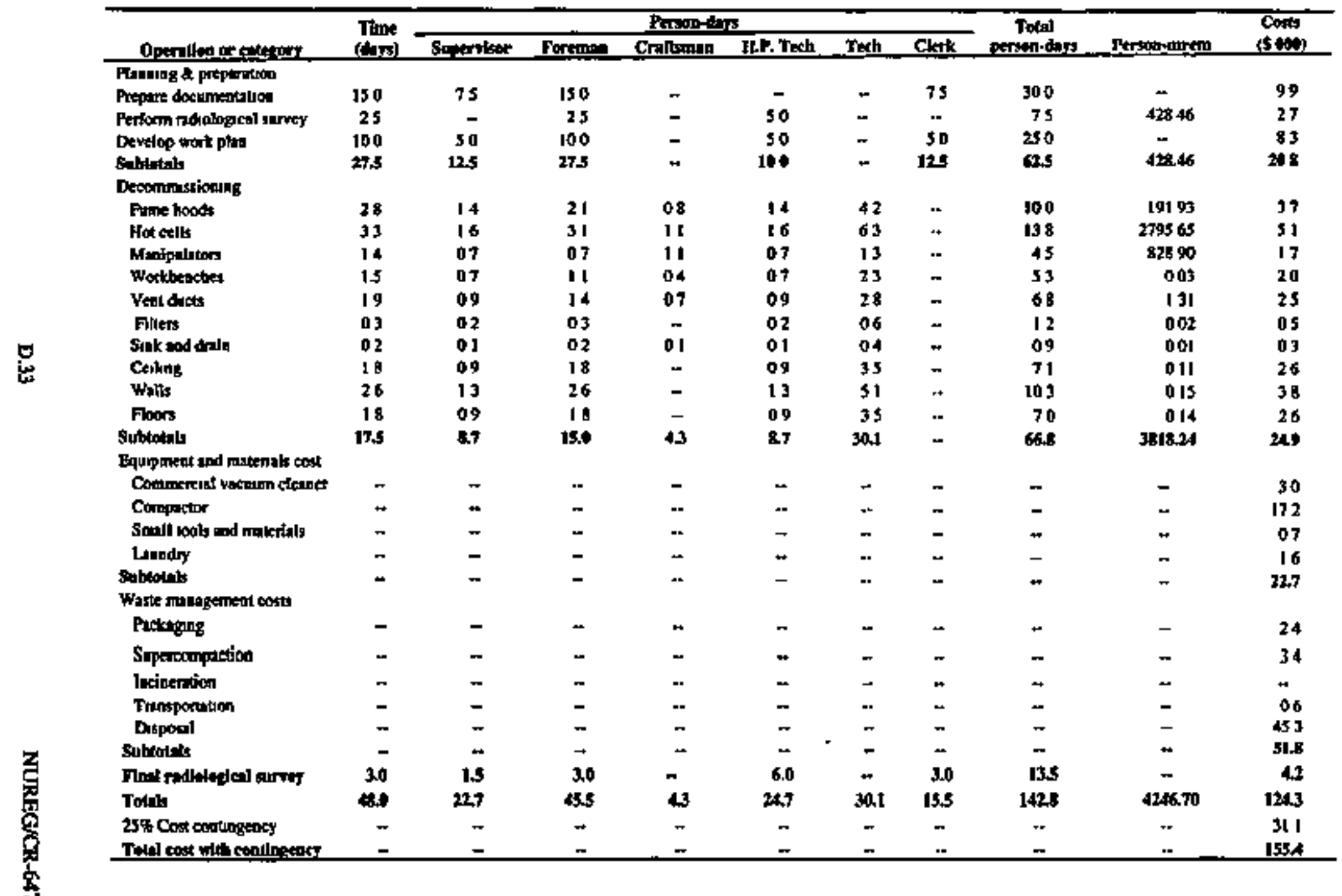




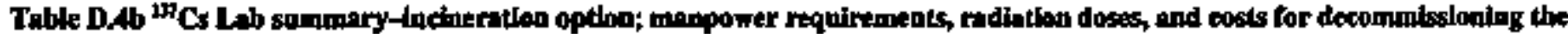

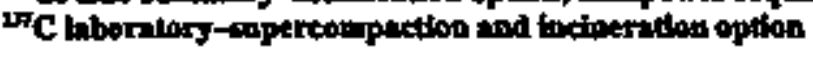

\begin{tabular}{|c|c|c|c|c|c|c|c|c|c|c|}
\hline \multirow[b]{2}{*}{ 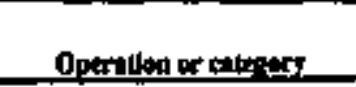 } & \multirow{2}{*}{$\begin{array}{l}\text { Tile } \\
\text { (duted) }\end{array}$} & \multicolumn{6}{|c|}{ Puseadaris } & \multirow{2}{*}{ 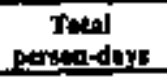 } & \multirow[b]{2}{*}{ Poptentarta } & \multirow{2}{*}{ Conts } \\
\hline & & Stepervisor & Fereming & Crollioming & H.P. Tech & Tecb & Ctak & & & \\
\hline \multicolumn{11}{|l|}{ Fleming \& greparalion } \\
\hline Propure documiealstion & 15.0 & 7.5 & is.0 & - & $=$ & .. & 7.5 & 300 & - & 9.9 \\
\hline Peform rodiologinal torrey & 25 & - & 2.5 & r & 50 & - & - & 35 & 428.46 & 2.7 \\
\hline Devekop work pluo & 100 & $\mathbf{5 . 0}$ & 100 & - & 50 & - & S.J & 250 & - & 8.3 \\
\hline \multicolumn{3}{|l|}{ Decoumnistioning } & 275 & & 104 & - & 125 & 625 & 428.46 & 208 \\
\hline Fuon boodts & 28 & 3.4 & $\mathbf{2 1}$ & 08 & I.d & 4.2 & 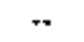 & 100 & 191,93 & 3.7 \\
\hline Hot cells & 33 & 1.6 & 3.1 & 1.1 & 2.6 & 63 & - & 13.8 & 279565 & 5.J \\
\hline Mniplatimers & 1.4 & 9.7 & 07 & 1.1 & 0.7 & 1.3 & - & 45 & 028.90 & 1.7 \\
\hline Wortbercks & 1.3 & $\mathbf{4 . 7}$ & t.I & 04 & 0.7 & 23 & - & 5.3 & oos & 20 \\
\hline Veíidueds & 1,9 & 0.9 & 1,4 & 0.7 & 0.9 & 28 & - & 6.8 & I.JI & 25 \\
\hline Filess & 03 & 02 & 03 & - & 02 & 0.6 & $*$ & 1.2 & 0.02 & os \\
\hline Sill und thin & 02 & 0.1 & 02 & 0.1 & 0.1 & 0.4 & - & 09 & 001 & 03 \\
\hline Ceitins & 18 & 0.9 & I 8 & - & 09 & 3.5 & 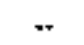 & 7.1 & $0 \mathrm{tz}$ & 26 \\
\hline Wals & 26 & 1.3 & 26 & - & 1.3 & 5.1 & 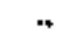 & 10.3 & 0.15 & 38 \\
\hline Fonan & 1.0 & 0.9 & 1.A & + & 0.9 & 3.5 & - & 7.0 & 0.14 & 2.6 \\
\hline Switotela & $17 s$ & $\mathbf{8 . 7}$ & 15.0 & 43 & k.7 & 3t.1 & $*$ & $6 \times$ & 3a18.24 & 24.9 \\
\hline \multicolumn{11}{|l|}{ Equipmet and notridals cost } \\
\hline Comnexinl veculat clemer & 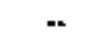 & - & - & - & - & - & - & - & - & 30 \\
\hline Conopocin & 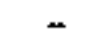 & - & - & - & - & - & - & - & -- & 172 \\
\hline Sontil took \& meteriats & - & - & - & - & $m$ & - & - & - & - & 0.7 \\
\hline Lanody & - & - & - & - & - & - & - & - & 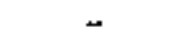 & 1.6 \\
\hline & \multicolumn{4}{|c|}{ Wette mingement costs } & - & - & - & & - & 227 \\
\hline Packaplog & 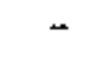 & + & - & - & - & - & - & - & - & 24 \\
\hline Suprexampection & - & - & - & - & - & - & - & - & - & 1,4 \\
\hline lacmenalion & - & - & - & - & - & - & + & - & - & 204 \\
\hline Transpontuod & - & - & - & - & - & - & -. & - & - & $0 \$$ \\
\hline Disposal & .. & 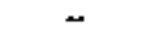 & + & - & - & - & 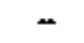 & - & - & 383 \\
\hline Subering & - & - & - & - & - & - & + & $\bullet$ & - & 40 \\
\hline Planl nedlelogiel survey & $\mathbf{H}$ & 15 & 3. & $*$ & 64 & - & 30 & 135 & $*$ & 42 \\
\hline Tatal & 480 & 213 & 458 & $\mathbf{4 3}$ & $\mathbf{2 k T}$ & 30.1 & 15.5 & 148 & $424 \times 10$ & I135.5 \\
\hline 25\% Cout contingeacy & - & - & - & - & - & $\cdots$ & - & - & - & 33.9 \\
\hline Tuld oot with conting & 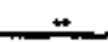 & $=$ & $=$ & $=$ & - & - & .. & $=$ & $=$ & 1694 \\
\hline
\end{tabular}




\section{Amount of Stainless Steel Upper Section}

Back: $15 \times 20$

Two sides: $2 \times 0.945 \times 2.0$

Foor and Tap: $2 \times 1.5 \times 0.945$

Total Area

Total Volume: $0.003175 \times 9.615$

Total Volume for 2 Hoods

Total Weight for 2 Hoods

Amount of Stalnkess Steel in the Lower Cablnet

Back \& Fronk; $2 \times 1.5 \times 0.90$

Two Sides: $2 \times 0.945 \times 0.9$

Bottorn \& Top: $2 \times 1.5 \times 0.945$

Total Area

Total Volume: $0.003175 \times 7.236$

Total Volume for 2 Hoods

Total Weight for 2 Hoods

$$
\begin{aligned}
& =3.00 \mathrm{~m}^{2} \\
& =3.78 \mathrm{~m}^{2} \\
& =2.835 \mathrm{~m}^{2} \\
& =9.615 \mathrm{~m}^{2} \\
& =0.03053 \mathrm{~m}^{3} \\
& =0.06106 \mathrm{~m}^{3} \\
& =488 \mathrm{~kg}
\end{aligned}
$$

\section{Amount of Mild Steet in the Exterior Frame}

This is assurned to be conprised of angle iron (0.0508 $\mathrm{m}$ by $0.04445 \mathrm{~m}$ by $0.004762 .5 \mathrm{~m}$ thick). The amoum of mild sleel is $4 \times 2.0 \mathrm{~m}$ for vertical members and $4 \times 1.5 \mathrm{~m}$ for horizontal members, for a jotal length of $14 \mathrm{~m}$. Tolat mitd steel in the fume hood frame is thus $14 \mathrm{ma} \times(0.050 \mathrm{O}+0.04445) \times 0.0047626=0.006351 \mathrm{~m}$.

Total Volume for 2 Hoods

Total Weight for 2 Hoods

$$
\begin{aligned}
& =2.700 \mathrm{~m}^{2} \\
& =1.701 \mathrm{~m}^{2} \\
& =2.835 \mathrm{~m}^{2} \\
& =7.236 \mathrm{~m}^{2} \\
& =0.02297 \mathrm{~m}^{3} \\
& =0.04594 \mathrm{~m}^{2} \\
& =368 \mathrm{~kg}
\end{aligned}
$$

\section{Amount of Acrylic Plastic in the Window}

The plastic is assumed to be $2.0 \mathrm{~m}$ high $\times 1.5 \mathrm{~m}$ wide $\times 0.00635 \mathrm{~m}$ thick, for a towal walume of $0.0190 \mathrm{~s} \mathrm{~m}^{3}$.

Total Volume for 2 Hoods

Total Weight for 2 Hoods (6.g. $=1.2$ )

Amount of Processing Equipment

$$
\begin{aligned}
& =0.01270 \mathrm{~m}^{3} \\
& =102 \mathrm{~kg}
\end{aligned}
$$

The foltowing general type of contaminated equipment is postulated to be presert in the fume hoods. The equipment is bagged and corpacted on-site, super-cumpacted off-site, and then cisposed of as LLW.

- 2 electric heating units, cach wighing about $7 \mathrm{~kg}$. These are assumed to take up about $0.03 \mathrm{mt}$ of space, exch. For 2 furne hoods, the total is 4 electric hesiing units, with a kotal weight of $28 \mathrm{~kg}$ and a total bulk volume of $0.12 \mathrm{~m}^{3}$.

- 6 significant iterns of processing glassware, each weighing about $3 \mathrm{~kg}$ and taking up about $0.02 \mathrm{~m}^{3}$ of space. For 2 fume hoods, the total is 12 vnits of processing glassware, with a totai weighi of $36 \mathrm{~kg}$ and a total bulk wolume of $0.24 \mathrm{mr}$.

- 4 ilems of various materials (metals, plastic, ceramtc), each weighing about $2 \mathrm{~kg}$. These are assumed to take up about $0.014 \mathrm{~mm}^{3}$ of space, eaxh. For 2 fume hoods, the total is 8 items, with a total weight of $16 \mathrm{~kg}$ and a total bulk volume of $0.112 \mathrm{~m}^{3}$. 
Appendix D

\title{
D.4.2 Fot Cells
}

The ${ }^{197} \mathrm{Cs}$ facility conlains two small hol cells construeled of interiocking lead bricks as the walls and a layer of lead bricks on each of the 10p and boltom of the hot celt (Reference 1. p. A-34-5). The fnside dimensions of the hot cells are the sane as a $1.2-\mathrm{m}$ cube, with a wall thickness of $0.1 \mathrm{~m}$. The top and bottoen shielding of the cells is assumed to also be $0.1 \mathrm{~m}$ of lead bricks. The eop slsielding is supported by a steel plate (assumed to be equivalent to 0.025-m-lhick). Two holes in the fop steel plate and the bricks there are used to insert one each of the vertical arms of masier-slave manipulainrs. The front of the hot cell has a viewing wizdow $0.6 \mathrm{~m} \times 0.6 \mathrm{~m} \times 0.141 \mathrm{~m}$ thick (hickness equivalent to the lead wall thichutess in garmms shielding effectiveness). The viewing window is made of lead glass that has the same gamma shieldisg power as steel. (Thus, it is assurned that the shielding window thickness is 1.41 times that of the lead brick, or $0.141 \mathrm{~m}$ ) The working surface floor inside the hoc ceil is lined with stainless steel (assumed to be $0.001588 \mathrm{~m}$ thick), which extends integrally up to a height of $0.1 \mathrm{~m}$ along each wall. The walls and ceiling of the hot cells are lined with plastic larninate (assumed to be polycarbonate $0.001588 \mathrm{~m}$ thick). Equipment and material are transferred between each hot cell and its adjacent fune hood through a stiding door on one side that reveals an opening to the fume hood The sliding door. a rectangular steel box filled with lead, is assumed to be $0.4 \mathrm{~m} \times 0.5 \mathrm{~m} \times 0.1 \mathrm{~m}$ thick. Each hot cell is supported by a concrete pedestal that is $0.76 \mathrm{~m} \mathrm{high}$ and 1,4 m an ercht side.

Decommotssioning of each hot cell involves removal of the equipment inside. (If the equipment needs ro be cul, it is done befoce removing the master-slave manipulators and disassembling the hol cell.) The irterior wall and fleor and window and door surfaces of the hot cell are vacunimed and wet-wiped with an aqueous solution that contitins a small arnount of detergent. The master-slave manipulators ase removed (see next section), then the hot cell is disassembled. The lead bricks are fisassembled from the hot cell, brick-by-brick, vacuumed, wet-wiped, and altowed to dry. The dried lead byicks and the lead-filled doer in the hot cell are bagged and placed in 208-liter drums that are sent direclly to radioactive-hazaudous mixed waste for encapsulation, then to disposal. The lead-glass window is vacuumed, wet-wiped and dried, and removed and bagged and placed in a 208 -liter drum (the window may be placed with other, lighter materials from the facility), then semt directly to U.W sisposal. The door to the fume bood is removed and bagsed and placed in a drum. (The door may be placed with kead bricks from the hox cells.) The intemal plastic laninate lines is removed, vactuumed, wer-wiped, painted and cut up co tit efficiently in a drum after bagging, for on-site compaction and oft-sile supercisnipaction before sending to $L L W$ ditposal. The conertie pedestal for the hot cell is vacuumed, wel-wiped, and paitiled with strippable decontanination paint. Hot spois are removed by additional spot decontaminatlon with strippable paint. Wet-wiping is done using rags and brushes and - dilute aqueous solution with a small amount of deterpent in a way that minimizes rutr-off or puddling.

\section{Anount of Lead in the Hot Cen}

This is eqaal to that in the 6 sides minus thal for the stilelditg window and the 2 manipulator holes. The volume of kad in the hot cell is $1.4 \times 1.4 \times 1.4$ (ourside cube) $-1.2 \times 1.2 \times 1.2$ (inside cavity). Fron this, we subtract the lead from the window space $(0.1 \times 0.6 \times 0.6)$ and the 2 holes far the manipulators (assumed to be $0.3048 \mathrm{~m}$ in diameter), of $2 \times 0.1 \times(\pi / 4)$ $x 0.3049 \times 0,3048$. The volumes become:

\author{
$2.744 \mathrm{~m}^{2}$ (outside cube) \\ minus 1.728 (inside cavity) \\ Sum -1.016 poss \\ minus 0.036 (wilodow hole) \\ mimus 0.0146 (manipulator holes), ot, \\ Net $0.9654 \mathrm{~m}^{3}$ of lend in hot cell.
}

For 2 bot cells, the total volume is $1.9308 \mathrm{~m}$. The bet weight is $10,900 \mathrm{~kg}$, 2ssuming a specific gravity of 11.3 . The lead is begged and placed in 208-itter dums, then sent direelly to radioective-bazarious mixed waste for encapsulation, and then to disposal. 
Amount of Lead and Staintless Steel ton the Hot Cell Door

Volume: $0.4 \times 0.5 \times 0.1$

$=0.020 \mathrm{~m}^{3}$

Total Volume for 2 Doors

$=0.040 \mathrm{~m}^{3}$

Total Weight

$=452 \mathrm{~kg}$

The small amounts of kead in the steel-boxed lead are not differentialed hare.

Amount of Stalniess Steel in the Hot Cell

This is the inaer Itiner of the bottom, and the 4 sides up 0.1 m high.

$\begin{array}{ll}\text { Volurne } 1.2 \times 1.2 \times 0.001588+1.2 \times 0.1 \times 4 \times 0.001588 & =0.00305 \mathrm{mt}^{3} \\ \text { Total Volune for } 2 \text { Hot Cells } & =0.00610 \mathrm{~m}^{3} \\ \text { Total Weight } & =48.8 \mathrm{~kg}\end{array}$

Amount of Plestic Lominate in the Hot Cell

Volume: $4 \times 1.1 \times 1.1 \times 0.001588$

$=0.00769 \mathrm{~m}^{3}$

Total Volume for 2 Hot Cells

Total Weight

$=0.01537 \mathrm{mi}^{3}$

$=23 \mathrm{~kg}$

Ampunt of Lended Glass in the Hot Cell

Volune: $0.141 \times 0.6 \times 0.6$

Total Volume for 2 Hot Celis

Total Weight

$=0.0508 \mathrm{~m}^{3}$

$=0.1016 \mathrm{~m}^{3}$

$=813 \mathrm{~kg}$

\section{Amonit of Mild Steet in the Hot Cell}

This is assurned to come from the 0.025 -nn-thict plate equivalent that supports the bricks on the top of the hot cell.

Volune: $1.4 \times 1.4 \times 0.0254$

Total Volume for 2 Hot Cells

Total Weight

$$
\begin{aligned}
& =0.0498 \mathrm{~m}^{3} \\
& =0.0996 \mathrm{~m}^{3} \\
& =797 \mathrm{~kg}
\end{aligned}
$$

Amount of Meterials frow Cleaslate the Pedestal for the Hot Cell

This is based on the quantides identified in Reference 1, p. 7-15; these are used here, with adjustment for the armount of surface area itrolved. The surface area of the pedestal is $\left[.4 \times 1.4\right.$ (top) $+4 \times 1.4 \times 0.76$ ( 4 sides) $=6.216 \mathrm{~m}^{2}$. Ratioing 1wice this area (for 2 hot celts) to the $48 \mathrm{mt}^{2}$ in the ceiling of the ${ }^{137} \mathrm{Cs}$ facility resuls in the following amounts of wastes:

- 1208 -liter drum of wet rags, frushes and contaminaved gloves and other clothing (Reference 1. p. E-30). These are assumed to be compacted or-sixe. sent off-site for supercompaction and LLW disposal. If the incineration option is used, the waste is incinerated off-rite, with the ashes inxed into a monolithic solid, and disposed of as LLW. It is assumet that other waste materisls could be added to the drum with these materials. Fstimated weigth of these wastes for $2 \mathrm{hot}$ cells hefore treatment is $19 \mathrm{~kg}$. 
Appendix D

- $0.26208-[i t e r$ dnums of aqueous deconamination solution (assumed to hive small amounts of delegents) and rinse solutions from washing/wiping decontamination, before solidification wilh an adsorbent material. il is assumed that other waste materials could be added to the dum with these materials. Estimated weigh of the waste for 2 hot cells before solidification is $4 \mathrm{t}$ kg. The adsorbed wastes are sent directly for disposal as LLW.

- 0.26 208-liter drum equivalent of removed strippable paint (assumed in this study) to be compacted an-site. It ts assumed that oher waste materiais could be added to the drum with these thaterials and the druncoukd be recompacted. Estimated weight of the waste for 2 hot cells is $6.3 \mathrm{~kg}$. The waste is compacted on-site, supercornpacted off-site, and then seat for disposal as L.LW.

\section{D.4,3 Master-Slave Manipulators}

Two pair of master-slave manipulators are used in each of the two het cells in the ${ }^{13} \mathrm{Cs}$ facility, for a toeal of four. The slave sections insert vertically through holes in the hot cell, with shitelding assumed to be arcund or within the maripulator. The master (operator) sections are also vertical, and the mechanisms besween the master and the slave sections are in horizontal tubes. It is assumed for that the master and slave seclions are cach about $\mathbf{2} \mathrm{m}$ kong, and the horizontal soction is about $1 \mathrm{~m}$ lang. The average dianeler of each section is assumed to be about $0.127 \mathrm{~m}$

The manipulators would be very difficult to decontminale at best, even with careful operational procedures and booling of the slave ends. Thus, it is assumed that the manipulators are removed, seetioned, bagged, and placed in 208-titer drums for compacling on-site, and superconpacting off-site before disposal as LLW.

\section{Amount of Material in Maplpulators}

Voltume $(\pi / 4) \times 0.127 \times 0.127 \times 5$

Total Volume for 4 Manipulators

Toal Weight for 4 Manipulators

$$
\begin{aligned}
& =0.0633 \mathrm{mr}^{2} \\
& =0.2533 \\
& =160 \mathrm{~kg}
\end{aligned}
$$

\section{D.4.4 Workbenches}

The ${ }^{1{ }^{1}} \mathrm{Cs}$ facility's single workbench is assumed to be $0.75 \mathrm{~m}$ deep, $0.9 \mathrm{~m}$ high, and $4 \mathrm{~m}$ long (Reference $1, \mathrm{p} .9-13$ ). It is construcied of laxex-enamel-painted wood (0.01905 in thick), and has a plastic-laminated top, assumed to be $0.001588+\pi$ polyerbonate. The workbench has a stainless steed sink mounxed in it at one end (Refertnce 1, p. 7-17). The workbersh is assumed to have one drawer $0.1524 \mathrm{~m}$ deep, and below that a shelf a few centimeters above the flow, with 2 doors for every meler of length. To simplify calculations, it is assumed that each drawer and each set of cabinet foors it the 4-m-length of workbench is 1 m wide, and a vertical plywood partel supports the benches overy I $m$ (a total of live panels).

Because of the proxinnty of the warkbenches to nadioactivity-containing components, afl of the workbench materials are assumed to be radioactive. The surfaces wilt be vacuumed and painted before custing up into pieces sized to effectively fill 2018-liter drums. These drums of materials will be sent off-site for supercompaction or incineration (if that option is used). followed by fixation of the resuling sshes.

\section{Amount of Wood in the Workbeach}

Area:

Front \& Back: $2 \times 0.9 \times 4$

Sides 4 Support Panels: $5 \times 0.75 \times 0.9$

Boltom \& Top: $4 \times 3 \times 0.75$

Sides \& Back of 4 Deawers; $4 \times 0.1524 \times 1+8 \times 0.1524 \times 0.75$

$$
\begin{aligned}
& =7.2 \mathrm{~m}^{2} \\
& =3.375 \mathrm{~m}^{2} \\
& =9 \mathrm{~m}^{2}
\end{aligned}
$$


Total Area

Total Volume: $21.099 \times 0.01905$

Tolsl weighk (s.g. $=0.8)$

A mount of Polycarbonale on Workhench Surfaces

Volutme: $4 \times 0.75 \times 0.001588$

Weight (s.g. $=1.5$ )

$$
\begin{aligned}
& =1.524 \mathrm{~m}^{2} \\
& =21.099 \mathrm{~m}^{2} \\
& =6.402 \mathrm{~m}^{3} \\
& =322 \mathrm{~kg}
\end{aligned}
$$

$$
\begin{aligned}
& =0.0048 \mathrm{~m}^{3} \\
& =7.2 \mathrm{~kg}
\end{aligned}
$$

Anownt of Processing Equipment on the Workbench not used to Support the Hot Cells

It is assumad that the workbenches were used for radioactive couming equipment, which had to stay ckan, for tools (again, assunsed to be free of contamination) for making small new parts for the hoi cells; for temporary storage of nonradioactive materials; for overpacking the products (again expected to be a relatively clean cperation); and other similar uses. The contaminated material beiow is to be bagged, loaded into 208 -liter dnums, compacted on-site, and sent off-site for supercampaction before being sert for disposal as LLW. The following genteral type of equipment is postulated to be present on the workbench:

- variaus hand vools. primarily skel $l_{+}$weighing a total estimated $3 \mathbf{~ k g}$, with a total gross bulk volume estimated to be $0.002 \mathrm{~m}^{3}$.

- 1 significant iten of processing glassware, weighing aboul $3 \mathrm{~kg}$. This item would weigh about $3 \mathrm{~kg}$ and would require an estimated 0.020 it of total bulk spater.

- 1 item of various materials (metals, plastic, ceramic), weighing about $2 \mathrm{~kg}$. The estimated weight for this ilem is $2.0 \mathrm{~kg}$. with an estimated total bulk wolume of $0.002 \mathrm{~m}$.

\section{D.4.5 Vent Ducts}

The ${ }^{107} \mathrm{Cs}$ facility contains $8 \mathrm{~m}$ of cylindrical ductwork $0.2 \mathrm{~m}$ in diameter and $15 \mathrm{~m}$ of rectangular ductwork $0.25 \mathrm{~m} \times 0.6 \mathrm{~m}$ in cross-section (Reference 1, p. 9-13). The ductwork is assumed to be stainless steel sheel metsl $0.0015875 \mathrm{~m}$ thick.

The ductwork is assumed to be radioactively contaninated internally and externally. The ductwork is vacuumed and wetwiped where possible to remove the resdily-removable conlaminalion, then paimed to minimize contamination during the next step of cuttigg into pieces and bagefing and packaging as L.LW. The duct waste is cur into pieces that maximize the amount of thaterial that can fit in 208-liler drums. The waste pieces are plased in plastic bags before being placed in the drubls. The waste-filled dums are then coripacted on-sike and then shipped off-site for supercompsetion before disposal as LLW.

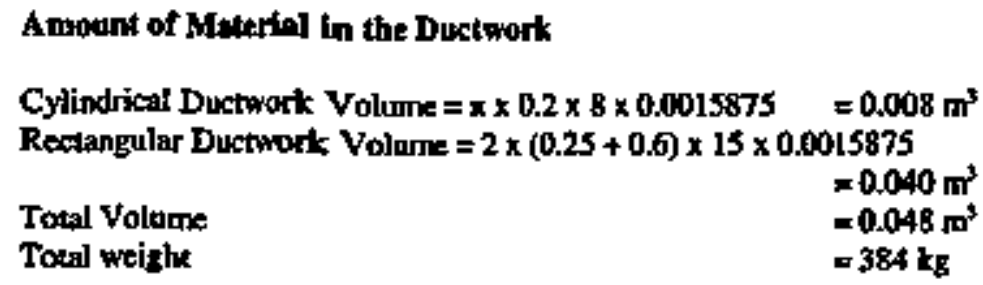




\section{D.4.6 Filters}

In the ${ }^{1 "} \mathrm{Cs}$ facility, each fure hood (2) and hot cell (2) has a small, round HEPA and roughing filter at its respective air outlet, and there is one larger HEPA and ronghing fiher on the facility's ventilation exhaust (Reference 1, pp. 7-19. 9-13) where the exhaust eniers the facility exhaust plenum. The round HEPA filiers are $0.2 \mathrm{~m}$ diameter $\times 0.2 \mathrm{~m}$ high; the round roughing filters are $0.2 \mathrm{~m}$ dtameter $\times 0.1 \mathrm{~m}$ high: the large, rectangular HEPA Efter is $0.25 \mathrm{~m} \times 0.6 \mathrm{~m} \times 0.3 \mathrm{~m}$; and the large. nectangular roughing filter is $0.25 \mathrm{~m} \times 0.6 \mathrm{~m} \times 0.15 \mathrm{~m}$. It is postulated that the facility filters had bees replaced at the end of the operating period, and they will last through-out the total decommissioning period. In addition, it is assumed that during the vacturning activity of the comporents and the facility, a commereisl vacuum unit is leased that uses a set af round coughing and HEPA filters jentical to those in the facility components, and 2 sets of filters are used during vacuuming. baking the total 6 sets. The filter removal is one of the last activities undertaken during decomrmissioning.

Each filitu is wropped in a plastic bag and sealed during its amoval. It is assumed that the fitters are made of sheet-inetal casing with plealed japer as the filter medtum. It is posttulated that the HEPA filters are bagged, placed in 208-titer drums for on-site compactlan, followed by shipuxem off-sile for supereompaction before being packaged for disposal as LLW.

\section{Amount of Meterials in the EEPA Fitters}

The bolk (rectangtar) volume of the 6 kitts is $6 \times 0.2 \times 0.2 \times 0.2=0.048 \mathrm{~m}^{3}$. The rectangular volume of he large HFPA filter $150.25 \times 0.6 \times 0.3$ n $0.045 \mathrm{~m}^{3}$. The total volume of all HEPA filters is thus $0.093 \mathrm{~m}^{3}$. The overall weight of each smalh

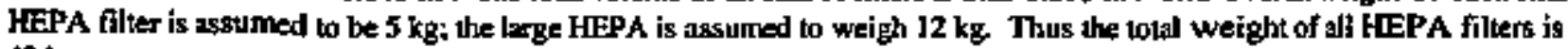
$42 \mathrm{~kg}$

\section{Amount of Materials in the Roughing Fitiers}

The bulk (rectangular) volume of the 6 fflters is $6 \times 0.2 \times 0.2 \times 0.1=0.424 \mathrm{~m}^{3}$. The rectangular volume of the large roughting filtex is $0.25 \times 0.6 \times 0.15=0.0225 \mathrm{~m}^{3}$. The lotal volume of all the roughing tiliers is thess $0.0465 \mathrm{~m}^{3}$. The overall weight of each small filter is assumed to be $25 \mathrm{~kg}$; the large soughing filter is assumed to weigh $6 \mathrm{~kg}$. Thus the total weight of all roughing fileass is $21 \mathrm{~kg}$.

\section{D,4.7 Sink and Drain}

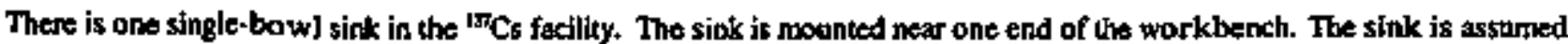
to be 18-gage stainless steel (0.001214 m thick) with inside uimenstons of $0.635 \mathrm{~m}$ wide $\times 0.5588 \mathrm{~m}$ long $\times 0.3048 \mathrm{~m}$ deep, with over.ll dinensions of $0.8382 \mathrm{~m}$ wide $\times 0.5588 \mathrm{~m}$ deep to allow for the flanges (Reference 2). The facility sink is used for personal clembliness. Liqutd effluent is discharged to a tank (assumed lo be outside) where it is held for monitoring before discharge to the sunilary sewer (Reference 1, p. 7-19). Contaminated liquids are not purposely discharged to the sapitary sewer vis the sink. Operational aqueous waste liqutds are not discharged to the laboratory sink system, but ant soltdified with a setting malerial and shipped out as LLW during operaiton. Operational organic waste tipuids ence absorbed ont an absorbent material that meets disposal facility requirements, and are shipped out as a solid L.LW during operation (Reference 1, p. 7-26). The sink and is associated water faucet, and the tcain piping to the facility walt are wiped down, removed, cut up to efficiently tuse space in the 208-liter drum, and wrapped in plaslic bags by a pipefitter, assisted by a cechnician. The waste materials are compacied on-stie, and supereompacted off-site before disposal as LI,W.

Amount of Stalaless Sitel in the Sink

The sink is assumed to weigh about $\left[2 \mathrm{~kg}\right.$ and to requite a hult volume of an estimated $0.113 \mathrm{~m}^{3}$. 
Amount of Brass lo the Foxture and Connections

The weight of the brass is estimated to be $3 \mathrm{~kg}$, assumping a specific gravity for brass of 8.75 . The brass will occupy about $0.0283 \mathrm{~m}^{3}$ of bulk space.

\section{Amount of Gulvanized Steel in the Draln and P Trap}

Thts is equivalent to $5 \mathrm{~m}$ of 0.1-m-diameter pipe (Reference 1, p. 2.9). or an estimated $16.05 \mathrm{~kg} / \mathrm{m} \times 4 \mathrm{~m}=64,2 \mathrm{~kg}$. The tulk volume of the traterial is estimated to be $0.05 \mathrm{~mm}^{3}$.

\section{D.4.8 Facility Celling}

The ${ }^{197} \mathrm{Cs}$ tatility contains $48 \mathrm{~m}^{2}$ of latex enamel painted concrete ceiling (Reterence 1, p. 7-19). The celling is decontarinated to unestricted kevels. Because the facilty ceiling is a sigid concrete structure, decontamination is done in ways to minjmize destruction of any significant part of the stucture and its enamet paint (although some of the enamel paint may be removed by the decontamination). The ceiling is first vacuunned, then wiped with wet rags and brushes. The decontaminating sollution, a dilute aqueous detergent, is applied sparingly to minimize dripping. After wel-wiping, the ceiling is wiped with dry rags and allowed to dry completely. Final decombamination is by use of a strippable patint that is applied whth brushes or rollers, allowed to dry, then strippes off with the contamination. Foal ho spots are manully wet-wiped, then dry-wiped, or possibly spolted with additional strippable paint. Only materisls used for decontamination tre assumed to become LLW.

\section{Amounls of Watte Matertals Resulting trom Deconlaminating the Ceiling}

The estimates developed in Reference 1, p. E-30, for the wasb/wipe operations seem reasonable for the decontamination procecoures osed in that study, but in this study, much less liquid decontartinating agent is used. with pat of the decontanination being done with strippable paint. Thus, the amount of rags, brushes, and liquif wastes is taken to be $1 / 3$ of that in Reference 1, with adjustrments for wall area. The extimates of waste materials from deconiamination and the subsequert waste treatinent are given below. Disposition of the final wastes is discussed in each of the three subsets of waste canegories below.

- 1208 liter dam of wet rags, brushes and contaminated gloves and other cloching. These are assumed to be contiplted on-atie, sest of f-site for supercompection and LLW dispossl. Ir the incineration option is used, the waste is incinerated off-sile, with the ashes fixed into a monotithic solid, and disposed of as $\mathrm{LLW}$. Estimaled weight of these wastes befoce treatment is $18 \mathrm{~kg}$.

- 0.25 208-liter inums of aqueous decontaningtion solutions (assumed to concatin small amounis of dekrgents) and rinse solotions from wet/wiping decontanination activities, before solidification on-site with an adsobent material. It is assuned that the drum can be filled with similar solutions from decontamination of oaher condponemis to fully use the drum space. The estimated weititu of the wastes before solidification is $40 \mathrm{~kg}$.

- 0.73 20ß-Jiles drums equivalent of removed strippable painl (assumed in this study) to be reduced to a smaller volune after on-site compacion). It is assumed that the drum can be filled with olber strippable pajin from decpmmissioning other components of the facility to jully use the drem space. The waste is compreted ob-site and sent off-site fort supercompaction before being disposed of as LLW. Eslimated weight of the LLW is $18 \mathrm{~kg}$.

\section{D.4.9 Facility Walts}

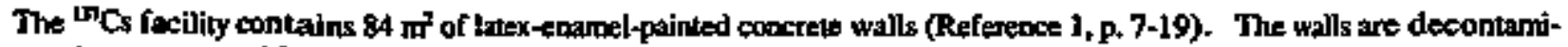
naled to unrestricted levels. Because the facility walls are rigid concrete struchres, decontanimation is done in ways to 
minimize destruction of any significant part of the structure and its enanel paint (although some of the emantel paint may be removed by the decoratamination).

The walls are first vacuurned, then wiped with wet rags and brushes. The decontanninating solution, a diloce aqueous detergent, is appliod spartingly to minimize dripping. After wet-wiping, the walls are wiped with dry rags and allowed to dry completely. Final decontamination is by use of a strippable paint that is applied with brushes or rollers, allowed to dry, them scripped off with the contamination. Fimat hot spols are manually wel-wiped, then dry-wiped, or spoted with another coat of strippable paint. Only mmerlals usod for decontamination are assumed 10 become LLW. Disposition of the final wastes is discussed in each of the three subsels of waste categories below.

\section{Ampunt of Waste Meterbis Respliting fren Decontamipating the Wals}

The estimates developed in Reference 1, p E-30, for the wash/wipe operotions seem reasonable for the decontaminstion procedures used in that sudy, but in this study, we are assurting much kess usage of liquid decontaninating agent, with part of the decontamination being conte with strippalbe paint. Thus, the ampont of rags, brushes, and liquid wastes is taken to be IB of that in Reference 1, wilh adjusiments for surface arez. The estimates of waste traterials from decontamination and the suthequent waste treatment are given below. Disposition of the finat wasles is discussed in each of the three subsets of waste categortes below.

- 1.67208 -liter drums of wet rags, brushes and contaminated gloves and other clothing. These are assumed to be compacled on-site, sent off-site for supetcompaction and LLW disposal. If the inciteration option is used, the waste is incinerated off-site, with the ashes fixed into a monolithic solid, and disposed of as LLW. The estimated weight of these wastes before treatment is $32 \mathrm{~kg}$.

- I.27 208-liter drums of aqneons decontamination solutions (zssumed to contain smal] amounts of detergents) and rinse solutions from weUtwiping decontamination, before solidi5tation with an adsorbent material. The estimated weight of the wastes before solidification is $70 \mathrm{~kg}$. The adsorted wastes are sent direelly for disposal as $\mathrm{LLW}$.

- 1.27 208-liter drums equivatent at removed strippoble paint (assumed in this study) to be combined with other strippable paint waste from decormissioning of this facility 10 efficieacly use drum space). The estimated weight of the $\mathbf{L W}$ is 32 kg. The waste is compacted on-site, supereompacted off-site, and sent for dispossl as $\mathbf{L W W}$.

\section{D.4.10 Facility Floor}

The ${ }^{137} \mathrm{Cs}$ facility floor contains $48 \mathrm{~m}^{2}$ of asphalt tile (postulated to be $0.0015875 \mathrm{~m}$ thick) over concrele (Reference 1 , p. 7-19). The foor is postulated to be first vacumed and ben painted to fix the rernaining contarninatios. The tites are manually retnoved and packaged in plastic bags in 208-liter drums as LLW. The remsining hot spots in the corserete flooring are cleaned by'a small amount of scobbling of the hot spots, Pollowed by re-vacuuming the entire floor saface. The contrete rutble and dust are then bagged and effieitenty packed tin drums. The dnums are conpacted on-site, then sealed and sent for disposal as LW.

\section{Amoutut of Waste Matedials Resulling from Renroving Floor Tites}

The total volume of floor tikes $* 48 \times 0.0015875=0.0762 \mathrm{~m}^{3}$. Assurning a specific gravity of 1.1 , the asphalt tiles would weigh an estimsted $85 \mathrm{~kg}$. The thor tiles are compacted on-site, supereompacted off-sile, and then sent for disposal as LLW. 


\section{Apount of Concrete Flooring Rernoved ts Radioactive Waste}

A number of the cracks between the tiles (assumed here to be $10 \%$ of the Moor ara) will have contarinated conerete that nects to be removed, assumed to a depth of $0.0127 \mathrm{~m}$. The total amount of concrete rubble and dust removed as radioactive waste is $48 \times 0.1 \times 0.0127=0.061 \mathrm{~m}^{3}$ of concrete as rubble and dust. Assuming the spectfic gravity is 60\% of theoreticat, the volume is 0.102 mit before compaction. The weigbt is estimated at $153 \mathrm{~kg}$. assuning a specific grawty of 2.5 . The concrete rubble and dust are postulated to be bagged and dnumed, then compacted on-site before dispost as LI,W.

\section{D.5 Reference Laboratory for the Manufacture of ${ }^{241} \mathrm{Am}$ Sealed Sources}

Detaited physica] descriptions and decomruissioning procedures fơn all the compoxtents and burilding sorfaces of the ${ }^{24}$ Am laboratory that are postulated to require jemoval and/or decontamination are given in Seetions D.S.J through D.5.11. Details of (1) planning and preparation, (2) estimated manpower requirements, (3) waste manspement, materials, and labor cosis, and (4) radiation dosages are presented in Table DS2 for the supercompaction option and in Table DSb for the supereompaction option with incinesetion. An overall desertplion of this laboratory is conlained in Section 7,1.S of Referemce 1.

\section{D.5.1 Fume Hoods}

Each of the ${ }^{2 n}$ Am facility's two fune hoods is $1.5 \mathrm{~m}$ witle $\times 2.0 \mathrm{~m}$ high $\times 0.945 \mathrm{~m}$ deep. Each fume hood is gssurned 10 be framed extemally by mild steel $0.003175 \mathrm{~m}$ thick and to contain acrylic windows $0.00635 \mathrm{~m}$ thick. Fach hood js as\$umed to rest on an enclosed stainless steel-based cabintl (Fis A-5-1. p. A-30. Reference 1.) The support cabinet is assumed to have the same faot print as the fume hood but is only $0.9 \mathrm{~m}$ high.

Before the fume hoods are dismantled, the interioe and exteriou surfaces are vacurumed and wet-wiped, then dried and painted to fix conlamination. The hoods are then cut to sizes that allow the tood miterials to be bagged and placed into 208 -íter doums in stuch a way that the materials can be jeasonably compacted on-site, then supercompscted off-site.

\section{Amount of Stainless Steel Upper Section}

Back: $1.5 \times 2.0$

Two sixies: $2 \times 0.945 \times 20$

Floor and Top: $2 \times 1.5 \times 0.945$

Total Are?

Total Volome: 0.003175 × 9.615

Total Volume for 2 Hoods

Total Weight for 2 Hoods

$$
\begin{aligned}
& =3.00 \mathrm{~m}^{2} \\
& =3.78 \mathrm{~m}^{2} \\
& =2.835 \mathrm{~m}^{2} \\
& =9.615 \mathrm{~m}^{2} \\
& =0.03059 \mathrm{~m}^{3} \\
& =0.06106 \mathrm{~m}^{3} \\
& =488 \mathrm{~kg}
\end{aligned}
$$




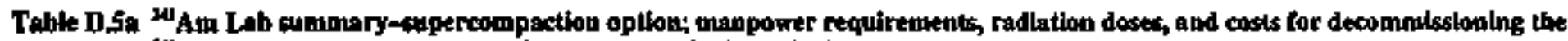

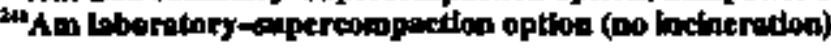

\begin{tabular}{|c|c|c|c|c|c|c|c|c|c|c|}
\hline \multirow[b]{2}{*}{ 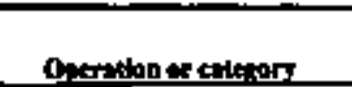 } & \multirow{2}{*}{$\begin{array}{l}\text { These } \\
\text { (dust) }\end{array}$} & \multicolumn{6}{|c|}{ Persog-dupg } & \multirow{2}{*}{$\begin{array}{c}\text { Tocol } \\
\text { gerong-dnyt }\end{array}$} & \multirow[b]{2}{*}{ Persian-mets } & \multirow{2}{*}{$\begin{array}{l}\text { Costs } \\
(\$ 000)\end{array}$} \\
\hline & & dusporter & Fortemin & Crontomen & 11.P.Tent & Itch & Gerk & & & \\
\hline \multicolumn{11}{|l|}{ Plenning \& potpatalion } \\
\hline Preparte dxcuoneatulion & IS.D & 73 & $\mathbf{I S} \mathbf{0}$ & - & - & - & 75 & 300 & .. & 9.9 \\
\hline Pertaxim nodiological sarvey & 4.5 & - & 4.5 & - & 9.0 & $=$ & - & 13.5 & 179823 & 4.8 \\
\hline Develop woot ptal. & 100 & 5.0 & 10.0 & - & $\mathbf{5 . 0}$ & ـ & 5,0 & 250 & -- & 83 \\
\hline Entocotilit & 2ys & 125 & 23 & $*$ & 140 & $\rightarrow$ & 12.5 & 68.5 & 1738.23 & 22.9 \\
\hline \multicolumn{11}{|l|}{ Decostinistionilog } \\
\hline Fune boods & 2.5 & 1.2 & 2.1 & at 6 & 1.2 & 42 & - & 93 & 91.61 & 35 \\
\hline Glare boxe: & 2.5 & 3.7 & 5.7 & 2.1 & 3.7 & 113 & - & 266 & $\mid 1473.31$ & 9.9 \\
\hline Wortbenation & 09 & 0.4 & 0.7 & 0.4 & 04 & 14 & - & 33 & 1.60 & 1.2 \\
\hline Vear duds & 2.9 & 1.4 & 2.2 & 1.1 & 1.4 & 43 & - & 104 & 1000 & 3.9 \\
\hline Cabiess & 0.4 & 0.2 & 03 & 0.1 & 0.2 & 06 & - & 1.4 & 2.61 & 0.5 \\
\hline Fivers: & 06 & 0.3 & 06 & - & 0.3 & 1.2 & - & 25 & 499 & 0.9 \\
\hline Centmsts & 1.8 & 09 & 1.8 & - & 0.9 & 3.6 & - & 7.2 & 14.33 & 21 \\
\hline Walls & 48 & 2.4 & 4,8 & - & 24 & 9.7 & - & 19.4 & 32.74 & 72 \\
\hline Flocers & l.g & 1.0 & 1.9 & - & 1.0 & 38 &.. & 76 & 38.98 & 28 \\
\hline Sillutatilt & $2,1.2$ & 116 & 20.1 & 4,2 & $11+6$ & 4.1.1 & $*$ & E7.7 & 11675_38 & 32.6 \\
\hline \multicolumn{11}{|l|}{ Equipoeat acd materials coust } \\
\hline 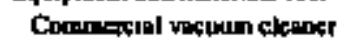 & - & $\omega$ & - & - & - & - & - & $\leftrightarrow$ & $\rightarrow$ & 30 \\
\hline Conpectar & - & - & - & - & - & * & - & - & - & 17.2 \\
\hline Snevil uols \& thalerials & - & - & - & - & - & - & - & -- & - & 1.0 \\
\hline Gondy. & - & - & - & - & - & - & - & -. & $*$ & 22 \\
\hline Sumatels & - & - & -. & 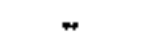 & $\rightarrow$ & - & - & - & - & 2,15 \\
\hline \multicolumn{11}{|l|}{ Wabs massgented costs } \\
\hline Pactapang & $*$ & $=$ & $=$ & $\leftrightarrow$ & 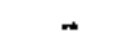 & - & - & - & - & 2.1 \\
\hline Soperonpactios & - & - & . & - & - & - & - & - & - & 43 \\
\hline focinerntion & $\omega$ & $\oplus$ & + & $\infty$ & 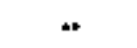 & - & 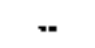 & ـ & $*$ & - \\
\hline Trespartalios & - & - & $\leftrightarrow$ & $*$ & - & .. & - & - & . & 0.6 \\
\hline Duspotal & -. & - & - & - & - & -. & $*$ & - & -. & 24.5 \\
\hline Sabcotall & - & - & - & -- & - &.. & .. & - & ** & 315 \\
\hline Flas radielo gical aurver & 50 & 25 & $s *$ & - & 10.0 & - & 5.0 & 225 & - & 69 \\
\hline Tolets & 57.7 & 26.6 & 34.6 & 42 & 35.6 & 40.1 & 175 & Ita.7 & [3036] & 117.5 \\
\hline 25\% cous conlingency & - & - & - & - & - & - & - & - & - & 29.4 \\
\hline 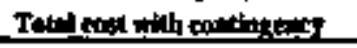 & - & $\leftrightarrow$ & 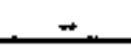 & - & - & - & - & - & - & 146. \\
\hline
\end{tabular}




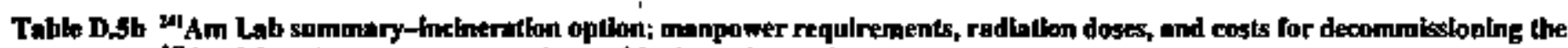
m Am laboratory-oupertoupection and incinetration optlon

\begin{tabular}{|c|c|c|c|c|c|c|c|c|c|c|}
\hline \multirow[b]{2}{*}{ Opentiog or ate. } & \multirow{2}{*}{ 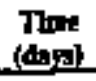 } & \multicolumn{6}{|c|}{ Prisondes } & \multirow{2}{*}{ 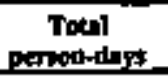 } & \multirow[b]{2}{*}{ Porten-men } & \multirow{2}{*}{$\begin{array}{l}\text { Costs } \\
(\$ 4 \omega)\end{array}$} \\
\hline & & Suparitone & Feneman & Confring & H.P.TEch & Trech & Get. & & & \\
\hline \multicolumn{11}{|l|}{ Phoofic a prepandoo } \\
\hline Prepare documentation & 150 & 15 & 15.0 & - & $-i$ & $\leftrightarrow$ & 7.5 & 30.0 & $\sim$ & 9.9 \\
\hline Perform mathologial stringy & 45 & $*$ & 45 & $=$ & 9.3 & - & 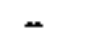 & 13.5 & 1798.23 & 48 \\
\hline Derelop work ptos & 100 & 50 & 100 & - & 50 & - & $s, 0$ & 250 & - & 8.3 \\
\hline Boblatals & 295 & 125 & 25.5 & - & 14. & - & 125 & 685 & 1796.23 & 20 \\
\hline \multicolumn{11}{|l|}{ Decoumissioting } \\
\hline Pune Doow & 2.5 & 12 & 2.1 & 06 & 12 & 4.2 & - & 93 & 9161 & 35 \\
\hline Glove bates & 75 & 3.7 & 5.7 & $2 . t$ & 37 & 113 & - & 266 & 11473.31 & 9.9 \\
\hline Worltacaches: & 09 & 04 & 0.7 & 04 & 04 & 1.4 & 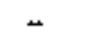 & 3.3 & 160 & 1.2 \\
\hline Veat dusts & 2.8 & 14 & 2.2 & 1.1 & t.d & 43 & - & 104 & 1000 & $\mathbf{3 . 9}$ \\
\hline Cobines & 04 & 0.2 & 03 & 0.1 & 62 & 06 & - & 1.4 & 261 . & 0.5 \\
\hline Filkers & 06 & 03 & 86 & - & 0.3 & 1.2 & - & 25 & 490 & og \\
\hline Cetiling & I B & 09 & 1.8 & - & 09 & 3.6 & . & 7.2 & $\$ 433$ & 2.7 \\
\hline wals & 48 & 24 & 48 & - & 24 & 97 & - & 19.4 & 36.74 & 72 \\
\hline Fosers & 1.9 & I. & 1.9 & - & 10 & 3.8 & - & 76 & 3808 & 2.8 \\
\hline Sintounls & 23.2 & 11.6 & 20.1 & 4.3 & 11.6 & $\$ 0.1$ & - & 87.7 & 11675.38 & 326 \\
\hline \multicolumn{11}{|l|}{ Hqutponcent and matertsls coel } \\
\hline Cormercial vatupm ckeaner & - & - & - & - & -- & 4 & - & r & $=$ & 30 \\
\hline Compactor & - & - & - & - & - & $r$ & - & - & - & $\mathbf{1 7 . 2}$ \\
\hline Small tools \& matertiols & - & - & - & - & $\hookrightarrow$ & - & - & - & - & 10 \\
\hline Lavuing & - & - & - & - & $*$ & - & - & - & - & 22 \\
\hline Sulvotuis & - & - & - & - & - & - & - & - & $*$ & 215 \\
\hline \multicolumn{11}{|l|}{ Waste nund gemkel conts } \\
\hline Squertompaction & - & - & - & $*$ & - & - & . & . & - & 2.1 \\
\hline Inciefration & - & - & - & - & & 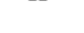 & & $"$ & - & 2.5 \\
\hline Teneportion & $\ldots$ & 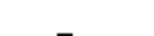 & 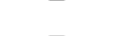 & 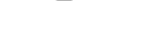 & - & - & - & - & - & 187 \\
\hline & - & - & - & - & - & 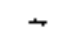 & $\omega$ & + & $=$ & 0.5 \\
\hline Disposal & - & - & - & - & 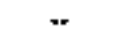 & - & - & $\because$ & - & 180 \\
\hline Sabiets &. & 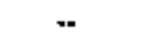 & - & - & - & $=$ & - & - & 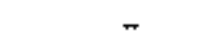 & 41. \\
\hline 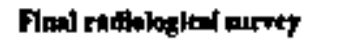 & 5.0 & 2.5 & 50 & - & 10.0 & - & 5.0 & 32.5 & - & ks \\
\hline Tobuld & ST.T & 266 & 346 & 4.2 & $\$ 5.6$ & $40 . t$ & 17.5 & 171.7 & $13 \min 3.61$ & 12T3 \\
\hline $25 \%$ Cost condtatsesy & 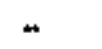 & - & - & - & - & - & - & 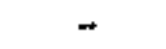 & $*$ & 31.9 \\
\hline 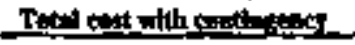 & $\rightarrow$ & 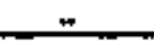 & 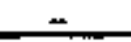 & 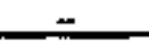 & $=$ & $\leftrightarrow$ & $*$ & $\approx$ & + & 159.7 \\
\hline
\end{tabular}


Appendix D

Amount of Stainiesa Steel in the Lower Cabinet

Back \&ront: $2 \times 1.5 \times 0.90$

Two Sides: $2 \times 0.945 \times 0.9$

Boitom \& Top; $2 \times 1.5 \times 0.945$

Total Avea

Total Volom: $0.003175 \times 7.236$

Total Volume for 2 Hoods

Total weight for 2 Hoods

$$
\begin{aligned}
& =2.700 \mathrm{~mm}^{2} \\
& =1.701 \mathrm{~cm}^{2} \\
& =2.835 \mathrm{~m}^{2} \\
& =7.236 \mathrm{~m}^{2} \\
& =0.02297 \mathrm{~m}^{3} \\
& =0.04594 \mathrm{~m}^{3} \\
& =368 \mathrm{~kg}
\end{aligned}
$$

\section{Amount of Muld Steel in the Exterlor Frame}

This is assumed to be comptised of angle iron $(0.0508 \mathrm{~m}$ by $0.04445 \mathrm{~m}$ by $0.0047625 \mathrm{~m}$ thick). The amaunt of mild steel is $4 \times 2.0 \mathrm{~m}$ for vertical nembers and $4 \times \mathrm{l} / 5$ q for horizonxal members, for a total lenght of $14 \mathrm{~m}$. Tocal mild steel in the furme hood frame is thus $14 \mathrm{~m} \times(0.0508+0.04445) \times 0.0047626=0.006351 \mathrm{~m}^{2}$.

Total Volume for 2 Hoods

Totsl Weitght for 2 Floods

$$
\begin{aligned}
& =0.0127 \mathrm{~m} \\
& =102 \mathrm{~kg}
\end{aligned}
$$

Amount of Acrylle Plastie in the Window

The plastic is assurned to be $20 \mathrm{~m}$ high $\times 1.5 \mathrm{~m}$ wide $\times 0.00635 \mathrm{~m}$ thick, for a wat volume of $0.01905 \mathrm{~m}$.

Total Volume for 2 Hoods

Total Weight for 2 Hoods (s.g- $=1.2$ )

$$
\begin{aligned}
& =0.0381 \mathrm{~m}^{\top} \\
& =46 \mathrm{~kg}
\end{aligned}
$$

\section{Amount of Processing Equipuent}

There is very little spate inside the fume hood fox processing equipment because ench furne hood contains a glove box that takes up most of the interior furne hood space. The following general type of contaminated equipment is postulated to be present in the furne hood. The equipment is bagged and conpacted on-site, super-compacted of $f$-site, and then disposed of as LLLW.

- 2 electric heating units, each weighing about $7 \mathrm{~kg}$. This is assurned to take up about $0.03 \mathrm{~m}^{3}$ of space. For 2 furne hoods, the otal is 4 electric heating units, with a total weight of $28 \mathrm{~kg}$ and a total bulk vohrme of $0.12 \mathrm{~m}^{3}$.

- 6 significanx iterns of processing glassware, each weighing about $3 \mathrm{~kg}$ and taking up about $0.02 \mathrm{~m}$ ' of space. For 2 fume hoods, the torl is 12 uniss of processing glessware, wilh a total weigth of $36 \mathrm{~kg}$ and a total ballk wolmme of $0.24 \mathrm{~m}$ '.

- 4 items of veriolss materials (metais, plastic, ceramic), each weighing about $2 \mathrm{~kg}$. This is $25 s u m e d$ to take up about 0.014 $\mathrm{m}^{3}$ of space. For 2 fume hoods the total is 8 items, with a total weighl of $16 \mathrm{~kg}$ and a tosal bulk volume of $0.112 \mathrm{~m}^{3}$.

\section{D.5.2 Glove Boxes}

The ${ }^{241}$ An facility contains seven plove boxes. Each glove box measures $1.2 \mathrm{~m}$ yide $\mathrm{x} 0.6 \mathrm{~m}$ high $\times 0.6$ deep (Reference 1 , p. 7-22). Each glove box is assurred to be frumed exiernally by mild skee $0.003175 \mathrm{~m}$ thick and to contain a 0.00635 m-athick arylic window. Exh box is postulated wo rest on an enclosed stainless stecl-based cabinet, sizailar to that for the fume hood, albove, but with differing foot print dimensions. The cabinet is assumed to have the same foot pritnt as the glove box but is only $0.9 \mathrm{~m}$ high. The glove box is assurned to bave a stainless steel pantel across the lower $0.25 \mathrm{~m}$ of the 
front, in which are located iwo 0.2-m-diameter clrcular openings fot neopsene working gloves. Above this panel, the front of the glove box slopes backward at an angle of about 40 degress, providing an opening for the acrylic plastic viewing window (assurned to be 0.00635 - m- -hick). The actylic plastic viewing window is mounted in a mild steel metal frame which is gasketed to the sloping fromt of the glove box. Six of the 7 glove boxes are in a row and each is connectad to the adjacent one(s) through a stainkess steel transfer tunnel. The transfer tunnel cross-section is $0.45 \mathrm{~m} \times 0.45 \mathrm{~m}$, and the stainless sleel there is assumed to be $0.003175 \mathrm{~m}$ thick. The total number of transfer tunnels is 5 and the total length of the unnels is $4 \mathrm{~m}$ (Reference l, p. 9-15), with an acrylic plastic door assumed to be kocated at the entrance and exit froon each of the in-line glove baxes. The 7th glove box, located independently, is also assumed to rest on its own mild stetl cabinet. Al one end of the indeperdent glove box and each of the two end glowe boxes that are in a row is a stainless steel atilack for the insenton of equipment and malerial inlo the box. Dimensions of the three airlocks are $0.3 \mathrm{~m} \mathrm{~h}$ gh $\times 0.2 \mathrm{~m}$ wide $\times 0.2 \mathrm{~m}$ deep (Reference 1, p. A.33). One acrytic air lock door of each air lock is accessible from outside the glove box, and one is accessible from the inside of the box through the use of glove ports. An acrylic door is assumed to be located in the 5 transfer lunnels on each of the 6 connected glowe boxes. Construction materials of the transfer tunnels is statnless steel. with no framework. Standard electrical receptacles are localed po the inside of each glove box, with power controlled by 8witches mounled outside on a service panel above the glove box.

Before dismantlement of the glove boxes, the interior and exterior box surfaces (as well as the air lock and transfer lunnel surfaces) are vaculumed and wel-wiped, and then are painied to fix contamination. The glove boxes are then cut to sizes that allow the bagged glove box materiats to go into 208-liter drums in such a way that the matertals can be reasonably compacted on-sile, supercompacted off-site, and then disposed of as $L W$. The acrylic plastic, the slect materials, and the equipment inside the glove box are segregated into drums, each with one of these categories of malerials.

\section{Amount of Stnintess Steet}

Area:

Back: $12 \times 0.6$

Botuom $1.2 \times 0.6$

2 sides: $2 \times 0.6 \times 0.6$

Top: $1.2 \times 0.3$

Front Panet: $0.25 \times 1.2$

Tosal Area

Total Volume: $2.82 \times 0.003175$

Total Volume for 7 Glove Boxes

Total Weight for 7 Glove Boxes

$$
\begin{aligned}
& =0.72 \mathrm{~m}^{2} \\
& =0.72 \mathrm{~m}^{2} \\
& =0.72 \mathrm{~m}^{2} \\
& =0.36 \mathrm{~m}^{2} \\
& =0.30 \mathrm{~m}^{2} \\
& =2.82 \mathrm{~m}^{2} \\
& =0.0089535 \mathrm{~m}^{2} \\
& =0.0626745 \mathrm{~m}^{3} \\
& =501 \mathrm{~kg}
\end{aligned}
$$

\section{Ampunt of Stoinless Steet in the Air Lacks}

Arta:

Back: $0.3 \times 0.2$

Top, Side, Botlom: $3 \times 0.2 \times 0.2$

Total Area

Total Volume $0.18 \times 0.003175$

Total Volume for 3 Air locks

Total Weight

$$
\begin{aligned}
& =0.06 \mathrm{~m}^{2} \\
& =0.12 \mathrm{~m}^{2} \\
& =0.18 \mathrm{~mm}^{2} \mathrm{t} \\
& =0.0005715 \mathrm{~m}^{2} \\
& =0.0017 \mathrm{t} 45 \mathrm{~m}^{2} \\
& =13.7 \mathrm{~kg}
\end{aligned}
$$


Appendix D

Amount of Stainless Stecl in the Transfer Tunnels

Volume: $4 \times 4 \times 0.45 \times 0.003175$

Total Volume for 5 Transfer turneis

Tocal weight for 5 Transfer Tuniels

$$
\begin{aligned}
& =0.02286 \mathrm{~m}^{3} \\
& =0.1143 \mathrm{~m}^{3} \\
& =914 \mathrm{~kg}
\end{aligned}
$$

Amount of Staintess Steel in the Lower Cablnet Section Below the Glove Box

Area:

Back and Fiont: $2 \times 1.2 \times 0.9$

Two Sides: $2 \times 0.6 \times 0.6$

Boutom and Top: $2 \times 1.2 \times 0.6$

Total Area

Total Volume: $4.32 \times 0.003175$

Totsl Volume for 7 cabinels

Total Weight for 7 cabinets

$$
\begin{aligned}
& =2.16 \mathrm{~m}^{2} \\
& =0.72 \mathrm{~m}^{2} \\
& =1.44 \mathrm{~m}^{2} \\
& =4.32 \mathrm{~m}^{2} \\
& =0.0137 \mathrm{~m}^{3} \\
& =0.0960 \mathrm{~m}^{3} \\
& =768 \mathrm{~kg}
\end{aligned}
$$

Amount of Mild Steel in the Exterior Frame of the Glove Box

This is postulated to be from angle iron, $0.0508 \mathrm{~m}$ wide $\times 0.0047625 \mathrm{~m}$ thick. The amount of mild steel is $4 \times 0.6 \mathrm{high}$ (for vertical neembers) + $5 \times 1.2 \mathrm{~m}$ wide (for horizontal members), or 8.4 linear meters, tolal.

Volume: $8.4 \times(0.0508+0.04445) \times 0.0047625$

Volume for 7 Glove Boxes: $7 \times 0.003810$

Weight for 7 Glove Boxest $\mathrm{B} 000 \times 0.02667$

$$
\begin{aligned}
& =0.003810 \mathrm{~m}^{3} \\
& =0.02667 \mathrm{~m}^{3} \\
& =30.5 \mathrm{~kg} .
\end{aligned}
$$

Amount of Acrylte Phestis in the Main Wiadow of a Glove Box

Volume: $0.6 \times 1.2 \times 0.00635$

Vohure for 7 Glove Boxes

Weight for 7 Glove Boxes: $1200 \times 0.032$

$$
\begin{aligned}
& =0.00457 \mathrm{~m}^{3} \\
& =0.032 \mathrm{~m}^{3} \\
& =38.4 \mathrm{~kg}
\end{aligned}
$$

Awount of Acrylie Plastle in Bach Altick Window of a Glove Box

Volume: $0.3 \times 0.2 \times 0.00635$

$=0.000381 \mathrm{~m}^{3}$

Volume for 3 Glove Box Airtocks or Transfer Tennels

Weight for 3 Glove Box Airlocks or Transfer Tumnels

$$
=0.0011 \mathrm{~m}^{3}
$$

$=1.37 \mathrm{~kg}$

Ampunt of Acrylle Ptostic in cach Transfer Tuane] Door of a Glove Box

Volume: $0.45 \times 0.45 \times 0.00635$

Volume for to Transfer Tunnet Doors

Weight for 10 Transfer Tumnel Doors

$$
\begin{aligned}
& =0.0013 \mathrm{~mm} \\
& =0.013 \mathrm{~mm}^{3} \\
& =15.6 \mathrm{~kg}
\end{aligned}
$$

\section{Amount of Processing Equipment in Each Glove Box}

The following general type of contaninated equipment, to te disposed of as $U W$, is postwated to be juesent in the glove boxes: 
- 2 electric heating untss, each weighing obout $7 \mathrm{~kg}$. These are assumted to take up about 0.0283 mi of space, each. For 7 glove boxes, the total is 14 eleciric healing units, with a tocal weight of $98 \mathrm{~kg}$ and a total butk volume of $0.198 \mathrm{I} \mathrm{m}$.

- 6 significant itens of proxessing glassware, each weighing aboul $3 \mathrm{~kg}$. These are assumed to take up about $0.02 \mathrm{~m}$ ' of space, each. For 7 glove boxes, the lotal is 42 units of processing glassware, with 8 cotal weight of $126 \mathrm{~kg}$ and a lotal bulk volume of $0.84 \mathrm{~m}^{3}$.

- 4 items of varlous materials (melals, plastic, ceramic), each wejghing about $2 \mathrm{~kg}$. These are assumed to lake up about $0.014 \mathrm{~m}^{3}$ of space, each. For 7 glove boxes, the total is 28 inems, with a total weight of $56 \mathrm{~kg}$ and a tokal bulk volume of $0.39 \mathrm{~m}^{3}$,

\section{D.5.3 Workbench}

The single workbench in the ${ }^{2 n}$ Am facility has a total top surface area of $I .5 \mathrm{~m}^{2}$ (Reference 1, p. 9-15). Assuming the workbench has the sarne width as those fox the other facilities in this study, or $0.75 \mathrm{~m}$, then the length of the bench is $2 \mathrm{~m}$. The bench is assumed to be $0.9 \mathrm{~m}$ high. The workbench is made of painted trild steel (axsumed to be $0.0015875 \mathrm{~m}$ thick) and his a top of stainless sleel, assumed to be $0.003175 \mathrm{~m}$ thick. The workbench is assumed to have two side-by-side drawers (below the surface) that are 0.1524 m deep, and below that, a shelf a few centimeters above the floor, with 2 doors for each meter of workbench length. To singlify calculations, it is assumed that each drawer and each set of cabinet doors in the workbench is $1 \mathrm{~m}$ wide, and that a vertical steel panel supports the bench every $1 \mathrm{~m}$ (a total of 1 panel plus (the two ends).

Because of the proximity of the workbench to radioactivity-containing components, all of the workbench materials are assumed to be radioactive. For decommissioning, the surfaces are vacuumed, wel-wiped, and painted before the bench is cut into pieces. The pieces are bagged and sized to effectively fitl 208-liter dirutrs. These drams of maleriats are compacted onsite and sent off-site for supercompaction prior to being overpacked for shipment and disposal as LLW.

Amount of Painted Mild Steet in the Workbench

Areas:

Front 8 Back: $2 \times 0.9 \times 2$

Sides Support Panels; $3 \times 0.75 \times 0.9$

Bottorn, Shelf \& Drawer Bottons: $2 \times 2 \times 0.75$

Drawer Sides: $2 \times 2 \times 0.75 \times 0.1524$

Bucks of 2 Dnwers: $2 \times 1 \times 0.1524$

Total Avea

Total Volume: $0.0015875 \times 9.387$

Tecal Weight: $8000 \times 0.0149$

$$
\begin{aligned}
& =3.6 \mathrm{~m}^{2} \\
& =2.025 \mathrm{~m}^{2} \\
& =3.0 \mathrm{~m}^{2} \\
& =0.4572 \mathrm{~m}^{2} \\
& =0.3048 \mathrm{~m}^{2} \\
& =9.387 \mathrm{~m}^{2} \\
& =0.0149 \mathrm{~m}^{1} \\
& =119 \mathrm{~kg}
\end{aligned}
$$

\section{Ampant of Stainless Steel on the Surtaces of the Workbench}

Volume $2 \times 0.75 \times 0.0031 \% 5$

Weight: $8000 \times 0.00476$

$$
\begin{aligned}
& =0.00476 \mathrm{~m}^{3} \\
& =36 \mathrm{~kg}
\end{aligned}
$$

\section{Amoart of Processtag Equipment on the Workbench}

It is assumed that the workbench was used for redionctive counting equipment that had to stay clean; for tools (again, assumed to be frex of contarnination) for making soral new paits for the hoods and glove boxes: for temporary storage of 
Appendix D

nonradionctive noterials; for weighing and overpacking the products (again, expected to be a relatively clean operation); and other similar uses. The following general type of contaminated equipment is to be disposed of as LLW (with compacting onsile, and supercompacting off-sire):

- Various hand tools, primarily steel, weighing a tolil estimaled $\mathrm{B} \mathrm{kg}$, with a total gross wolume estimated to be $0.005 \mathrm{st}$

- 2 signifieant items of processing glassware, each weighting about $3 \mathrm{~kg}$ and each occupying about $0.0 \mathrm{~m} \mathrm{~m}$ of spape. For the 2 giass iterss, the items would wejgh a total of about $6 \mathrm{~kg}$ and regulre $0.040 \mathrm{mg}^{3}$ of iotal bulk space.

- I additional ittem that could be made of yarious materials (metals, plastic, cerarric), weighing about $2 \mathrm{~kg}$ and occupying a volume of about $0.002 \mathrm{~m}^{5}$.

\section{D.5.4 Vent Ducts}

The ${ }^{241}$ Am facility contains 38 linear meters of polyvinyl chloride pipe (Refecence I, p. 7-23, 9-15). There are exhaust ducts from each of the two fame hoods and from each of the 7 glove boxes. The ductwork is composed of $18 \mathrm{~m}$ of 0.2-rn-diameser PVC pipe and $20 \mathrm{~m}$ of rectangular pipe $(0.25 \mathrm{~m} \times 0.6 \mathrm{~m})$. All pipe is assunged to be $0.003175 \mathrm{~m}$ thick.

The ductwork is assumed to be contaminated internally and exiernally. The ductwork ts vacuumed and wet-wiped where possible to remove the teasfly-removable contamination, then painted eo minimize contamination. The duct waste is cut into pieces and pur into plastic bags. The pieces are cut so as to maximize the amount of material that ean fit in 208-liter waste druns. The waste-filled druns are compacted on-site and then shipped off-site for supercompaction before beting disposed of as ILW.

Amount of PVC Material In the Roond Ductwork

Volume: $\pi \times 0.2 \times 18 \times 0.003175$

Weight: $1400 \times 0.0359$

$$
\begin{aligned}
& =0.0959 \mathrm{~m}^{3} \\
& =50 \mathrm{~kg}
\end{aligned}
$$

Amount of PVC Material in the Rectangular Ductwork

Volume: $20 \times(2 \times 0.25+2 \times 0.6) \times 0.003175$

Weight: $1400 \times 0.108$

$$
\begin{aligned}
& =0.108 \mathrm{nt}^{3} \\
& =151 \mathrm{~kg}
\end{aligned}
$$

\section{D.5.5 Cabinets and Sheli Unit}

The ${ }^{2+1}$ Am facility has one cabinet (Reference I, p. 7-22) for storing nonradioactive supplies. The cabinet is postulated to be constructed of painted wood $0.01905 \mathrm{~m}$ thick. The dimensions are 2550 med to be 0.762 m wide $x 0.4572 \mathrm{~m}$ deep $\times 1.524 \mathrm{~m}$ high. The cabinet is postulated to have two kxking doors and three shelves, plus the botion inside shelf.

The eabinet Is piven only mijd decontamination by vactuming and wet-wiping. It is then painted, sectioned, bagged, and placed in 208-irillon drupst whith are compacted on-site. The sectloning is done in a way that efficienlly uses the space in the drums. The drums ane then shipped off-sile for stiperrompaction. If the incinerstion option is used the waste is serx offsite for incineration and fixation of the whes into a monolithic solid. The fixed solid is sent for disposal as LLW. 


\section{Amount of Materiel in the Cabinet}

Area:

Fint \& Back, $2 \times 0,762 \times 1.524$

Two Sides: $2 \times 0.4572 \times 1524$

Top, Bottom, 3 Shelves; $5 \times 0.762 \times 0.4572$

Total Area

Volume: $5.458 \mathrm{I} \times 0.0190 \mathrm{~S}$

Wejght: $800 \times 0.104$

$$
\begin{aligned}
& =2.3226 \mathrm{~m}^{2} \\
& =1.3935 \mathrm{~m}^{2} \\
& =1.742 \mathrm{~m}^{2} \\
& =5.4581 \mathrm{~m}^{2} \\
& =0.104 \mathrm{~m}^{2} \\
& =83 \mathrm{~kg}
\end{aligned}
$$

\section{D5.6 Fulters}

The exhaust ducts from each of the two fume hoods and from each of the seven glove boxes in the ${ }^{24}$ Am fxility include a roughing fiher and a HEPA filler, for a totel of nine sets of roughing and HEPA fijters at the exhaust from each component. The HEPA filers are $0.2 \mathrm{~m}$ in diameter and $0.2 \mathrm{~m}$ high; the roughing filters are $0.2 \mathrm{~m}$ in dianeter and $0.1 \mathrm{~m}$ high (Reference 1, p. 9.15). The fihers are assumed to have frames of stainless steel and use pleated paper as the filter mediums At the point where the component exhasst air meets the facility exhaust plenum, aroothes bank of larger maghing/HFPA filiers is used. These filters are larger and resengular, with the HFPA filters measuring $0.25 \mathrm{~m} \times 0.6 \mathrm{~m} \times 0.3 \mathrm{~m}$, and the roughing filters measuring $0.25 \mathrm{~m} \times 0.6 \mathrm{~m} \times 0.15 \mathrm{~m}$. It is postwlaled that the lacility filters had been replaced at the end of the operating period, and that they will last throughout the tolal decomnissioning period. In addition, it is assumed that during the vecuraring activity of the conponents and the factity. a commercial vacuum unil is leased that uses a round roughing filter and a round HEPA filter identical to those in the factlily. Two sels of these filters are used during vacutuming. bringing the tosal number of srnali, round HFPA/roughing fitter sels to II. The filter removal is one of the last activities undetaken during decomutissioning.

Il is assurned that the filters are comprised of sheet-metal casings with plealed paper as the filler medium. It is postulaled that the HEPA filters are bagged, ptaced in 208-liter dnms for on-site compaction, followed by shipmeat off-site for superconpaction, before being packaged for disposal as $L L W$.

\section{Amount of Materials in the Small, Round HEPA Fitters}

The overalt weight of each small, nound HEPA titer is assumed to be $5 \mathrm{~kg}$. The estimated wright of the II strall, nound HitPA filters is thas $55 \mathrm{~kg}$. The bulk (nectangular) volurite of the 11 filters is $11 \times 0.2 \times 0.2 \times 0.2=0.088 \mathrm{~m}^{3}$.

\section{Amownt of Matertiks in the Large, Rectangular HEPA Filers}

The overall wejpht of each targe, rectangular HEPA fitur is assumed to be $12 \mathrm{~kg}$. The volume of each large, rectangular HEPA filter is $0.25 \times 0.6 \times 0.3=0.0450 \mathrm{~m}^{3}$.

\section{Amount of Matertels in the Sman, Roond Roughing Fitters}

The ovenll weight of each roughing fiter is assumed to be $2.5 \mathrm{~kg}$. The estimated weight of the $1 \mathrm{l}$ moghing filcers is thess $27.5 \mathrm{~kg}$. The bulk (rectangular) volume of the 11 filters is $11 \times 0.2 \times 0.2 \times 0.1=0.044 \mathrm{~m}^{3}$.

A mount of Matertals in the Larger, Rectaopular Roughing Filter

The overal] weight of the rectangular Joughing filer is assumed to be $6 \mathrm{~kg}$. The bulk volume of the rectangutar roughiag fliter is $0.25 \times 0.6 \times 0.15=0.0225 \mathrm{~m}^{3}$. 
Appendix D

\section{D.5.7 Facility Ceiling}

The 2a1 Am facility contains $60 \mathrm{~m}^{2}$ of concrete ceiling that is all painted and sealed with acrylic paint (Reiterence 1, p. 9-15). The ceiling is decontaminated to unrestricted levels. Becanse the facility ceiling is a rigid concrete structure, decontarni+ nation is dont in ways to minimize destruction of any significant part of the structure and its paint (although some of the paint may be removed by the decontamination). The ceiling is first vacuumed, thea wiped with wet rass and brushes. The decontaminating solution, a dilute aqueous detergent, is applied sparingly to minimize dripping. After wet-wiping, the ceiling is wiped with dry rags and allowed to dry completely. Final decontaminationt is by use of a strippable paint that is applied with brushes or rollers, allowed to dry, then stripped off with the contantinatiou. Final hot sposs are manvally wetwiped, then dry-wiped, or spotled with strippable paint. Only materials used for decontamination are assumed to become UW.

Amounts of Waste Mnterials Resulding from Decontaminating the Celling

The estirnales developed in Refenence 1 for the washwipe operations are reasonable for the decontaminalion procedures used in the original study, but in this study, contsiderably less lifuid decontanjinzing agent is used, and part of the decontamination is done with strippable paint. Thus, the amount of rags and brushes, and liquid wastes here is taicen to be $1 / 3$ of that in Reference I, with adjusements for surface area. The estimates of waste materials from deconlamination and the sutsequent waste treatment are given below, Disposition of the final wastes is discussed in each of the three subsets of waste categories below.

- 1.33208 -liter drams of wet rags, brushes, and contaminaled gloves and other clothing (Reference 1, p. E-30). These are assumined to be compacted on-site, sent off-sine for supercompaction and LIW disposat. If the imeineration option is used, the waste is incinerated off-stte, with the ashes fixed into a monolithic soltd, and Jisposed of as LW. Estingued weight of these wastes before trealment is $24 \mathrm{~kg}$.

- 0.33 208-liter dnums of squeous decontamination solutions (assumed 10 contain small amouras of detergents) and rixse solutions from wethiping deconlaminalion, beforo solidificalion with an adsabtent material. It is asstumed that the drum can be filled more folly with simtlar solutions frem decontamination of other components to fully use the drum space. Estimated weight of the wastes before soltdiftcalion is $53 \mathrm{~kg}$. The adsoubed wastes ara sent directly for disposal as LLW.

- 0.97 208-iter drums equivalent of removed strippable paint (assumed in this study) to be reduced to a smaller volume after on-site compaction). It is assunted that the drum can be filled with other strippable paint from decommissioning other comporients of the facility on fully uso the drum space The removed strippable paint is compacied on-site. superconpacted off-site, and then sent for disposal as LLW. Estimated weight of the LLW is $24 \mathrm{~kg}$.

\section{D.5.8 Facility Walls}

The 211 Am faclity contains $168 \mathrm{~m}^{2}$ of concrete walls painied with acrylic paint (Reference 1, p. 9-15). The walls are deconthminaled to unrestricted kevels. Because the facility walls are rigid conerete structores, decontamination is done in ways to mintizize destrution of any slgnificant part of the structure, and its acrylic paint (athough some of the acrylic paint may be renoved by the decontanination). The walls are first vacuurned, then wiped with wet rigs and brushes. The decontantnaring solution, a dilute aqueous deresgers, is applied sparingly to minimize dripping. After wet-wiping, the walts art wiped with dry rags and allowed to dry completely. Final decontarination is by use of a strippable paint ihat is applied with brushes or rollens, allowed to dyy, then stripped off with the contamination. Fintal hot spots are manusly wet-wiped, then dry-wiped, or spotted with another cost of strippable paint. Only materials used for decontamination are assumed to become LLW. 
The estirrates developed in Reference l for the wash/wipe operations seem reasorable for the decontanination procedures used in the original study, but in this study, considerably less liquid decontaminating agent is used, and part of the deconlamination being done with strippable paint. Thus, the amount of rags and brushes, and liquid wastes here are taken to be $1 / 3$ of those in Reference 1. with adjustments for wall area. The estimates of waste materials frem decontamination and the subsequent waste veatment are given below. Disposition of the final wastes is discussed in esch of the three subsets of waste catcogortes below.

- 2.67208 -jiter dnans of wet rags, bnushes and contaminated gloves and other clothing (Reference 1, p. E-30). These are assunned to be corppacted or-site, sent off-site for supereompaction and LLW disposal. If the incineration option is used, the waste is inciserated off-site, wilh the ashes fixed into a monolithic solid, and disposed of as LLW. Estimated weight of these wastes before treatment is $51 \mathrm{~kg}$.

- 0.67 208-líler drums of equeous deconamination solutions (assumed to contain small amounts of detergents) and ninse sotutions from wet/wiping decontamination, before solidifitsion with an addorbent material. Estimsted weight of the wastes befiore solidification is $112 \mathrm{~kg}$. The adsarbed wastes are sent directly for dispasal as L.LW.

- 2.0208 -liter dnurns equivalent of removed strippable paint (assumed in this study) to be combined with other strippable paint waste from decomrrissioning of this facility to efficiently use drum space). Estimated weight of the L.LW is $51 \mathbf{~ k g}$. The removed strippable paint is compacted on-site, supercompacted off-sâle, and then sent for disposal as LLW.

\section{D.5.9 Facility Floor}

The facility contains $60 \mathrm{~m}^{2}$ of concrete covered with linoleusen postulated to be $0.0015875 \mathrm{~m}$ thick. Alt the linoleum joints are heat-sealed. The linoleum is turned up at the walis to form 0.15-m cove corners with the walts (Reference 1 p. 7-22). The floox is postulated to be decontaminated 10 unrestricled use levels. The floor is first vacuuthed and then wet-wiped down with ragg atd brushes that mininize use of ltquld decomaminating agents and keep the decontaninaling agents from: paddling. The wash-wipe decontarminating agent is a dilute aqueous detergent. After the wel-wipe, the floors are then drywiped, and alkowed to dry completely in the room air. Finat decontamination is by use of a strippable paint that is applied with brushes or rollers, allowed to dry, then stripped off with the contamination. Final hot spots are mandally wet-wiped. then dry-wiped, of spot decontamination with another cost of strippable paint. If this final decontanninotion of hot spots does not remove the rematning flaor contamination, the thr spots will be carved out of the linoleum. The renowed linoleum is bagged and placed in the LLW dnums. Removal of coricrele flook material is not considered to be necessary. The solid materials used for floor decontaminstion are assumed to be bagged into 208-liter drums and set for disposal as LLW.

\section{Amounts of Wuste Materials Resulling from Decontaminatiog the Floor}

The eslimates developed in Reference I for the wash/wipe operations seem reasonable for the decontanination procedures used in the origital study, bul in thts study, considerably less liquid decontarrinating agent is used, and part of the decontamination is done with strippable paint. Thiss, the ancunt of rags and brushes, and liqujd wastes here are taken to be th of those in Reference 1, with adjutstments for wall area. The estimates of waste malerials from decontamination and the subsequent waste treatment are given below. Disposition of the final wastes is discussed in each of the three subsets of waste categories below.

- 1.33 208-liker drums of wet rings, brushes asd contaminated gloves and other cloching (Reference I,p. E-30). These are assumed to be cornpacied on-site, sent off-site for supercompaction and LLW disposal. If the incineration option is used, the waste is incineraled off-silt, with the ashes fixed into a nonolithic solid, and disposed of as LWW. Estimated weight of these wastes before trestment is $24 \mathrm{~kg}$. 
Appendix D

- 0.33 208-liter druns of aqueous decontamination solutions (assumred to contain small anounts of detergents) and rinse solutions from wethiping decontzmination, before solidifiction with an adsorbent material. It is assurned that the drum can be filled thore fully with sirtilar solutions from decontamination of oeber components to fully use the drum space. Estinated weight of the wastes before solidification is $53 \mathrm{~kg}$. The adsorbed wastes are sem directly to disposal as LLW.

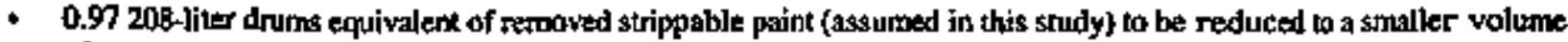
after ob-site compaction). It is assumed that the doum en be filled with other strippable paine from decomraissioning other companents of the faxility to fully use the drum space. The waste is compacied on-site and seat for supercompaction of -8 ite before being disposed of as ILW. Estimaled wright of the LLW is $24 \mathrm{~kg}$ -

\section{D.6 Reference Laboratory for the Reference Institutional User Facility}

Detajled physical descriplions and decommissioning procedures for all the components and but]ding surfaces of the user facility that are postulated to require removal and/or decontamination are given in Sections D.6.I through D.6.12. Details of (1) plarning and preparation, (2) estimaled manpower requirements, (3) waste planagement, matertals, and labor costs, and (4) radiation dosages are presented in Table D.6a for the supercompaction option and in Table D.6b for the supercoirqaction option with incineration.

As showa in Reference 1, p. 7-27. the user facility occupies two rooms that comprise one-half of a wing in a building, where the other half is separsted by a haltway (l.e., (wo walis). The raftoactlve half of the facility is also divided into two rooms with a connecting door, these rooms are the main labortory tacility and the animsl laborslory facllity (the falter is aboust onethird of the rediowctive half). Although some parts of the facility in the non-radiosctive half of the buinting contain radioactivity (e.t., counting areas, an equiprnent rwom where sealed radionctive waste containers are interimr-stored, a freczer for contamintated antinal cancasses), these areas are not considered to be part of the User facility for decommissioning purposes.

\section{D.6.1 Fume Hoods}

The user factility contains three fume hasods in the radioisotope nom and iwo in the animal laboratory, for a lotal of five. Each fume hood is $1.5 \mathrm{~m}$ wide $\times 2.0 \mathrm{~m}$ high $\times 0.945 \mathrm{~m}$ deep. Exhl hood is assurxed to be framed by mild stecl externally, with 0.003175-m-thick floor and walts The floer of the hood is statnless steel, and the walls are assumed to be 0.003175 -m-thick stoel with plastic laminate covering (assumed to be $0.00 t 5875$ m thick). Each hood is equipped with an acrylite window 0.00635 $\mathrm{m}$ thick. Each hood is assumed to rest on an enclosed stainless steefl-based cabinet (Reference 1. Figure A.5-1. p. A30). The support cabinet is assumed to have the same foot print as the fume hood box is only $0.9 \mathrm{~m} \mathrm{high}$.

Before the fume boods are dtsmantled, the interior and exterior surfaces are vacuumed ano wet-wiped, and then dried and painted to fix contamination. The hoods are then cut to sizes that alkow the hood materials to be bagged and placed in 208-liter drums in such a way that the materials can be reasonably compacted on-site, then supereorngacted off-site. 
Table D.6a User lab summary-aupercompaction option; maupower requlrements, radiation doses, and costis for decomulssioning the Institultonat tsotope user facility-supercompaction optlon (tio breinernithon)

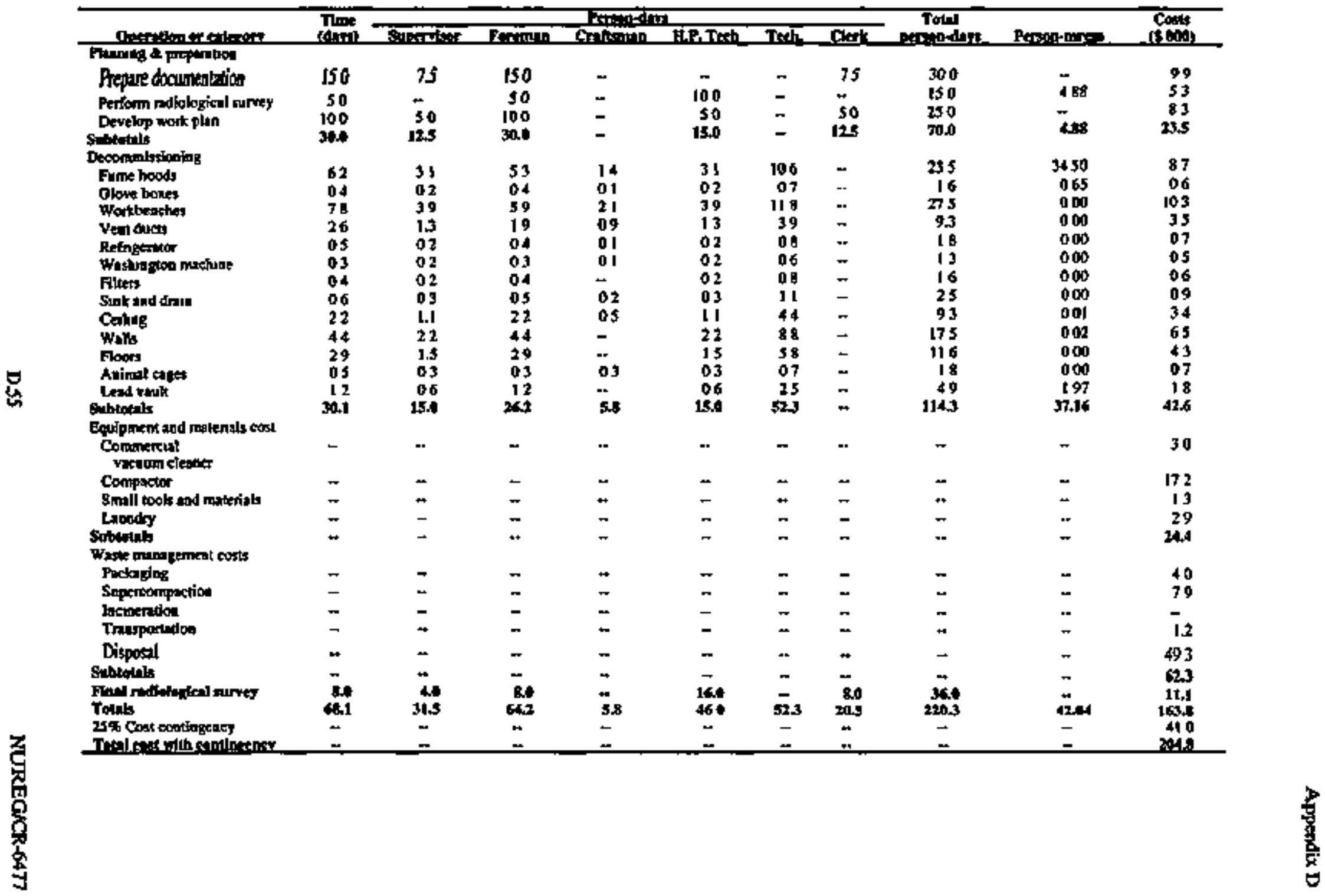




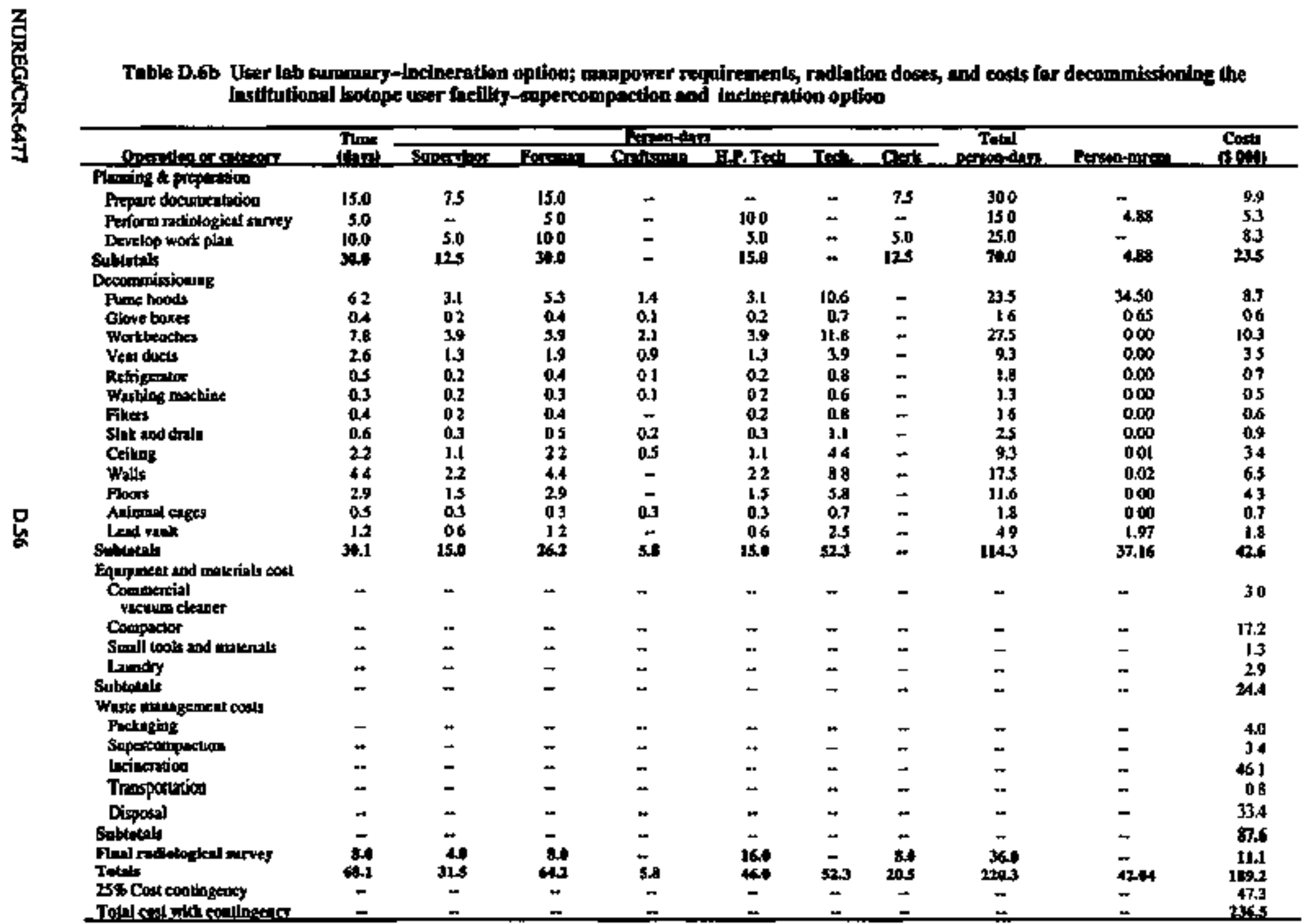




\section{Amount of Stainless Steet Upper Section}

Baçk: 0

Two sides: 0

Floor and Top: $2 \times 1.5 \times 0.945$

Total Area

Tolal Volume: $0.003175 \times 2.835$

Totsl Volume for 3 Hoods

Tolal Weight for 5 Hoods

Amount of Stoinless Steti in the Lower Colbint

Back \& Front: $2 \times 1.5 \times 0.90$

Two Sides: $2 \times 0.945 \times 0.9$

Hottom \& Top: $2 \times 1.5 \times 0.945$

Total Area

Total Volume: $0.003175 \times 7.236$

Total Volume for 5 Hoods

Total Weight for 5 Hoods

$$
\begin{aligned}
& =0.0 \mathrm{~m}^{2} \\
& =0.0 \mathrm{~m}^{2} \\
& =2.835 \mathrm{~m}^{2} \\
& =2.835 \mathrm{~m}^{2} \\
& =0.009 \mathrm{~m}^{3} \\
& =0.045 \mathrm{~m}^{3} \\
& =360 \mathrm{~kg}
\end{aligned}
$$

$$
\begin{aligned}
& =2.700 \mathrm{~m}^{2} \\
& =1.701 \mathrm{~m}^{2} \\
& =2.835 \mathrm{~m}^{2} \\
& =7.236 \mathrm{~m}^{2} \\
& =0.02297 \mathrm{~m}^{3} \\
& =0.1149 \mathrm{~m}^{2} \\
& =919 \mathrm{~kg}
\end{aligned}
$$

\section{Amount of Mlld Steel in the Exterior Frame}

The exierior frame is assumed to be comprised of angle iron (0.0508 $\mathrm{m}$ by $0.04445 \mathrm{~m}$ by $0.0047625 \mathrm{~m}$ thick). The anount of motld stect is $4 \times 2.0 \mathrm{~m}$ for vertical members and $4 \times 1.5 \mathrm{~m}$ for horizontal members, for a total length of $14 \mathrm{~m}$. Total mild stee] in the fume hood freme is thus $14 \mathrm{~m} \times(0.0508+0.04445) \times 0.0047626=0.006351 \mathrm{~m}^{3}$.

Tota: Volume tor 5 Hoods

Total Weighte for 5 Hoods

$$
\begin{aligned}
& =0.03176 \mathrm{~m}^{3} \\
& =254 \mathrm{~kg}
\end{aligned}
$$

\section{Amount of Mild Steed in the Walls}

Buck: $1.5 \times 2$

Two Sides $2 \times 0.945 \times 2$

Tocal Area

Total Volume: $6.78 \times 0.003175$

Total Volume for 5 Fume Hoods

Tokbl weight for 5 Fume Hoods

$$
\begin{aligned}
& =3.0 \mathrm{~m}^{2} \\
& =3.78 \mathrm{~m}^{2} \\
& =6.78 \mathrm{~m}^{2} \\
& =0.02153 \mathrm{~m}^{2} \\
& =0.1076 \\
& =861 \mathrm{~kg}
\end{aligned}
$$

Amouat of Partic Laminule on Walls

Same area os in d.

Volume: $6.78 \times 0.0015875$

Voleme for 5 Hoods

Weight: $1500 \times 0.0538$

$$
\begin{aligned}
& =6.78 \mathrm{~m}^{2} \\
& =0.01076 \mathrm{~m}^{3} \\
& =0.0538 \mathrm{~m}^{3} \\
& =81 \mathrm{~kg}
\end{aligned}
$$

Ameuat of Aerylle Pastle in the Whow

The plastic is assumed to be $2.0 \mathrm{~m}$ high $\times 1.5 \mathrm{~m}$ wide $\times 0.00635$ m thick, for a tetal wolume af $0.01905 \mathrm{~m}^{3}$. 
Appendix D

Total Volume for 5 froods

Total Weight for 5 Hoods (s.g. = 1.2)

$=0.09525 \mathrm{~m}^{3}$

$=[\mathrm{l} 4 \mathrm{~kg}$

Amount of Processing Equipment

The following general type of contaminated equipment is posiclated to be present in the fume hood. The equipment is bagged and compacted on-site, super-conmpacted off-site, and then disposed of as LLW.

- 2 electric heating units, eath weighing about $7 \mathrm{~kg}$. These are assumed to take up about $0.03 \mathrm{~m}^{3}$ of space, each. For 5 furte hoods, the tolat is 10 electric beating units, with a totat weight of $70 \mathrm{~kg}$ and a total bulk volume of $0.3 \mathrm{~m}^{3}$.

- 6 significant items of processing glasswart, each weightng about $3 \mathrm{~kg}$ and taking up about $0.02 \mathrm{~m}^{2}$ of space. For 5 fume hoods, the total is 30 units of processing glassware, with a tolal weight of $90 \mathrm{~kg}$ and a tolal bulk volume of $0.6 \mathrm{~m}^{3}$.

- 4 iterns of various materials (metals, plastic, ceramic), each wejghing about $2 \mathrm{~kg}$. These are assumed to take up about $0.014 \mathrm{~m}^{3}$ of space, tach. For 5 fume hoods, the lotal is $20 \mathrm{items,} \mathrm{with} \mathrm{a} \mathrm{total} \mathrm{weight} \mathrm{of} 40 \mathrm{~kg}$ and a tolal bulk volums of $0.284 \mathrm{~m}$.

\section{D.6.2 Glove Boxes}

The user facility contains one glove bax in the radiofsoxope roonl. The box is $0.9 \mathrm{~m}$ wide $\times 0.6 \mathrm{~m}$ high $\times 0.6 \mathrm{~m}$ deep (Reference l. p. A.33), rests on one of the workbenches and is assumed to bo framed by mild steel extemally, with 0.003175 -m-bick stainless steel walls, and 0.00635-m-lhick acrylic windows. The glove box has a staintess steel pane) across the lower $0.25 \mathrm{~m}$ of the front, in whith are located lwo 0.2-m-diameter tircular openings for plastic working gloves. Above this pant, the front of the glove box slopes backwand at an angle of about 40 degees, providing an opening for the acrylic plastic viewing window. The viewing window is mounted in a uild steel metol frane which is gasketed to the sloping front of the glove box. Al one end of the glove box is a stainless steel aiflock for the insertion of equipanent and material into the box. Airtoxk dimensions are $0.3 \mathrm{~m}$ high $\times 0.2 \mathrm{~m}$ wide $\mathrm{x} 0.2 \mathrm{~m}$ deep (Reference 1 , p. A.33). One acrylic air lock door is accessible from outside the glove box, and one is accessible from the inside of the box through the use of glove ports. Standerd electrical receptacles are located an the inside of the glove box, wilh power controlled by switches mounted outside on a service panel above the glawe box.

Before the glove box is dismantled, the interiox and exterior surtaces are vacummed and wet-wiped, and then painted to fix contamisation. The glove box is then cut into pieces that allow the bagged glove box materials to go inlo 208-liter drums in such a way that the materials ean be ressonably compacted on-site, supercompacted off-stie, and then disposed of as LLW, The atrytic plasti:, the steel materials, and the equipment inside the glove box are segregated into 208-liter drums, each wilh coe of these categories of materials.

Amount of Stainless Sienl in Ghove Box aud Access A L Lock

Glove Bax Proper.

Back: $0.9 \times 0.6$

Bottanx $0.9 \times 0.6$

Two sides: $2 \times 0.6 \times 0.6$

Top: $0.3 \times 0.9$

$=0.54 \mathrm{~m}^{2}$
$=0.54 \mathrm{~m}^{2}$
$=0.72 \mathrm{~m}^{2}$
$=0.27 \mathrm{~m}^{2}$

NUREGAR-6477 
Lower Fronx Panel: $0.25 \times 0.9$

Total Area

Total Volume: $0.003175 \times 2.295$

Air Lotk.

Back: $0.3 \times 0.2$

Top, Side, Botiom: $3 \times 0.2 \times 0.2$

Todal Ares

Total Volume: $0.003175 \times 0.16$

Tatal Staintess Steel Volume

Total Strintess Steed Weigh
$=0.225 \mathrm{~m}^{2}$

$=2.295 \mathrm{~m}^{2}$

$=0.00729 \mathrm{~m}^{3}$

$$
\begin{aligned}
& =0.06 \mathrm{~m}^{2} \\
& =0.12 \mathrm{~m}^{2} \\
& =0.18 \mathrm{~m}^{2} \\
& =0.0005715 \mathrm{~m}^{3} \\
& =0.00786 \mathrm{~m}^{3} \\
& =63 \mathrm{~kg}
\end{aligned}
$$

\section{Amount of Mitd Sted in the Exterior Frame}

The exterior frame is assumed to be comprised of angle iron ( $0.0508 \mathrm{~m}$ by $0.04445 \mathrm{~m}$ by $0.0047625 \mathrm{~m}$ tick). The amount of mild steel $\$ 4 \times 0.6 \mathrm{~m}$ for vertical members and $4 \times 0.9 \mathrm{~m}$ for horizontal members, for a total length of $6.9 \mathrm{~m}$. Total mild sieel in the frame is ubus $6.9 \times(0.0508+0.04445) \times 0.0047626=0.00313 \mathrm{~m}^{3}$.

Total Volume

Total Weight

$$
\begin{aligned}
& =0.00313 \mathrm{~m}^{3} \\
& =25 \mathrm{~kg}
\end{aligned}
$$

\section{Amount of Acrylle Plastic in the Main Windom and Air Lock}

Maln Windor. The plastic is assumed to be $0.6 \mathrm{~m}$ high $\times 0.9 \mathrm{~m}$ wide $\mathrm{x} 0.00635 \mathrm{~m}$ thick, giving a volume of $0.003429 \mathrm{~m}^{3}$.

Airiock. Each of the two winkows is assumed to measure $0.3 \times 0.2 \times 0.00635$. This gives a total volume of $0.000762 \mathrm{mt}$.

Total Volume of Acrylic; $0.003429+0.000762$

Total Weight of Acrylic: $1200 \times 0.00419 \mathrm{I}$

$$
\begin{aligned}
& =0.004191 \mathrm{~m}^{3} \\
& =5 \mathrm{~kg}
\end{aligned}
$$

\section{Ampuat of Processing Equlpment}

The follawing general type of confaminated equiprnent is postutaled to be present in the glove boxes. The equipment is basged and compacted on-site, super-compacled aff-site, and then disposed of as L.LW.

- 2 electric heating units, esch thighing about $7 \mathrm{~kg}$. These are assumed to tatce up about $0.03 \mathrm{~m}^{3}$ of space, each. For the one glove box, the total is 2 electre heating units, with a total weight of $14 \mathrm{~kg}$ and a totat bulk velume of $0.06 \mathrm{~m}$.

- 6 significant items of processing glasswart, each weighing about $3 \mathrm{~kg}$ and takjng up about $0.02 \mathrm{mt}^{3}$ of space. For the onte glove box, the total is 6 units of processing glassware, with $\mathrm{a}$ total weight of $18 \mathrm{~kg}$ and a total bulk volume of $0.12 \mathrm{~m}^{3}$.

- 4 itens of vaious materials (metals, plastic, ceramic), each weighing aboux $2 \mathrm{~kg}$. These are assumed to take up about $0,0\left[4 \mathrm{~m}^{\prime}\right.$ of space, each. For the one glove box, the total is 4 items, with a total weight of $8 \mathrm{~kg}$ and a total bulk volume of $0.056 \mathrm{~m}$. 


\section{D.6.3 Workbenches}

The user' facilly has two separate workbenches. The first is a long ore with three "L's" from it to form the letter "E". The second is in the shape of an "L" (Reference 1, p. 7-27, and 9-18). The workbenches are $0.9 \mathrm{~m}$ bigh and assumed to be $0.75 \mathrm{~m}$ wide. The total length of the two benches is $24 \mathrm{~m}$. The workbenches are constructed of wood (assuned to be 0.0 [90S meters thick), and have a plastic-laminated top (assumed to be $0.0015875 \mathrm{~m}$ thick polycarbonate) the other wood surfaces are painted wtah latex enarnel. Three wockbench locations contain a stainless steed sink; at a fourth loctation rests a plove box. These workbenclyes are assumed to have one drawer that is $0.1524 \mathrm{~m}$ deep and below that, a shelf a few centimeters above the floor, with two doars, for evey linear meter of workbench. To simplify calculations, it is assumed that each drawer and each set of cabinet dows in the 24m-length of workbenches is $1 \mathrm{~m}$ wide, and a vertical plywood panst supports the benches every $1 \mathrm{~m}$ (a total of 29 panels).

Becsuse of the proximity of the workbenches to radioaclivity-containing components, alt of the workbench materials are assemed to be radioastive. The surfaces are to be vacuumed, wet-wiped, and painted before cutting up into pieces sized to effectively fill 208-liter droms. These drutrs of materials are compscted on-site, and sent off-site for supencompaction or incineration (if that option is used), followed by fixation of the resulting ashes.

\section{Amount of Wood in the Workbenehes}

Back \& Front: $2 \times 0.9 \times 24$

Sides \& Support Panel: $29 \times 0.75 \times 0.9$

Botion \& Top: $24 \times 3 \times 0.75 \times \mathrm{t}$

Sides \& Back of 24 Drawers $24 \times 0.1524 \times(0.75+0.75+1)$

Total Area

Tatat Volume: $125.919 \times 0.01905$

Total weight: $800 \times 2.40$

$$
\begin{aligned}
& =43.2 \mathrm{~m}^{2} \\
& =19.575 \mathrm{~m}^{2} \\
& =54 \mathrm{~m}^{2} \\
& =9.144 \mathrm{~m}^{2} \\
& =125.919 \mathrm{~m}^{2} \\
& =2.40 \mathrm{~m}^{3} \\
& =1.920 \mathrm{~kg}
\end{aligned}
$$

It is assumed that the incinerated wood yields an ash content of 5 w\% before incorporation into monolithic solids for disposal as LLW.

\section{Anount of Polycurbonate on the Sarfaces of the Workbenkbes}

Volume: $24 \times 0.75 \times 0.0015875$

$=0.028575 \mathrm{~m}^{3}$

Weight: $1500 \times 0.028575$

$=42.9 \mathrm{~kg}$

\section{Amount of Proxealing Equipment on the Workbenches Not Used to Support Glove Boxes}

It is assurned that the workbenches were used for radioactive counting equipment, which had to stay cleas; for tools (again, assumed to be free of contamination) for mating smal] new parts for the hoods and glave boxes; for temporary storage of nonradiosctive materials; for overpacking the products (again, expected to be a relatively clean operation); and other sintilar uses. The conteminated equipment and material below are to be bagged, loaded into zos-liter drums, compacted on-site, and supercompacted off-site before being disposed of as LLW.

- Various hand tools jochding a vist, primariby steel, wtighing a total estinated $12 \mathrm{~kg}$, with a total gross bulk volume estimared to be $0.008 \mathrm{~m}^{3}$.

- 2 significant items of processing giassware, each wejphing about $3 \mathrm{~kg}$. Fort the 2 glass items, the items would weigh about $6 \mathrm{~kg}$ and would require an estimted $0.0400 \mathrm{nt}^{3}$ of total bulk space. 
- 2 itear of various materials (metals, plastic, cerarnic), each weighing about $2 \mathrm{~kg}$. For these ftems, the total weight is estimat at $4 \mathrm{~kg}$. with an estimated tolal belk volume of $0.004 \mathrm{~m}^{3} \mathrm{~m}$.

\section{D.6.4 Vent Ducts}

The user facility comains $12 \mathrm{~m}$ of cylindical ductwork $0.2 \mathrm{~m}$ in diameltr and $20 \mathrm{~m}$ of roctangular ductwork $0.25 \mathrm{~m} \times 0.6 \mathrm{~m}$ in cross-section (Reference 1, p. 9-18). The ductwork is assumed to be stainless steel sheet metal $0.0015875 \mathrm{~m}$ thick.

The ductwork is assumed to be radjoactively contaminared imlentally and externally. The ductwork is vacaumed and welwiped where possible to remove the readily-removable contamination, then painied to minimize contamination during subsequent steps. After paining, the duet waste is cul into pieces that maximize the amount of materbal that can fit in 208-Jiter drums. The waste pieces are placed in plastic bags betore being placed in the drums. The waste-filled drums are then compacied on-sile and then shipped off-site for supercompaction before being sent 1o L.LW disposal.

Amount of Material in the Ductwork

Cylindrical Ductwork Volume

Rectangular Ductwaxk Volume

Tolal Volume

Tolal weighe

$$
\begin{aligned}
& =5 \times 0.2 \times 12 \times 0.0015875=0.012 \mathrm{~m}^{3} \\
& =2 \times(0.25+0.6) \times 20 \times 0.0015875 \\
& =0.054 \mathrm{~m}^{3} \\
& =0.066 \mathrm{~m}^{3} \\
& =528 \mathrm{~kg}
\end{aligned}
$$

\section{D.6.5 Sinks and Drains}

The user facility contains three sinks. Two sinks sre in the radioisolope room, and one is in the animal taboralory. Associated with the rinks are 15 linear m of 0.1-m-diameter drain pipe (Reference 1, p. 9-18). Each sink is assumed to be 18-gage stainless steel (0.001214 m thick) with inside dimensions of $0.635 \mathrm{~m}$ wide $\mathrm{x} 0.5588 \mathrm{~m}$ high $\mathrm{x} 0.3048 \mathrm{~m}$ deep, and wich overali dimensions of $0.6382 \mathrm{~m}$ wide $\times 0.5588 \mathrm{~m}$ deep 10 allow for the flanges (Reference 2, p. J049). One sink (on the north wall of the radioisotope room) is reserved for washing contaminated dishes and for discarding substances that have low specific radioattivity. The other two sinks do nos receive any rdioactivity except through accidental contamination. Drains for the sinks are carried above the Door line to simplify mainienance. The dratins from the three sinks are conmected in common at the northwest comer of the buikding. A common drain line penetrates the boilding floor at this point and goes underground vo a 2,000-liter stainless steel holding tank buried outside the building. In the holding tank, the liquid effluem is held for radioactive decay, monitored, and diluted es necessary before discharge to the sanitary sewer. Water frown a spray fixture in the tank may be used to flush the wastes to the sewer. The decommissioning of the outside drain line and holding ani are not incluried in this section, bul ks covered elsewhere.

The sinks and instile drains are all assoned to be contartinated. The sinks and their associated water fancels and the drain piping to the facility junction point are wiped down only, removed, cut up in a way that uses space effictently in the 2018-liter drum, and then put in plasbic by a pipefitter and a technician. The waste nttiltrials are compacted on-site, and supercompacted off-site before trinsport to LLW disposil.

\section{Amount of Stulatess Steel in the Sink}

Each sink is assurned to weigh about $12 \mathrm{~kg}$ and to require $\mathrm{abull}$ volume of an estimaled $0.113 \mathrm{~m}^{3}$.

Total Volume for 3 Sinks Total Weight for 3 Sinks

$$
\begin{aligned}
& =0.339 \mathrm{~m}^{3} \\
& =36 \mathrm{~kg}
\end{aligned}
$$


Appendix D

\section{A mount of Brass tn the Fixture and Connections}

The weight of the brass is estimated to be $3 \mathrm{~kg}$, assurning a specific gravily for brass of 8.75 . The brass wilf occupy about $0.0283 \mathrm{~m}^{3}$ of bulk space.

Total Volume for 3 Sinks

$=0.849 \mathrm{~m}^{3}$

Total Wejght for 3 Sinks

$$
=9 \mathrm{~kg}
$$

\section{Amount of Galvanized Sleet in the Draln and P Trap}

This is equivalent to $5 \mathrm{~m}$ of $0.1-\mathrm{m}$-dianets pipe (Reterence $1, \mathrm{p}$. 2-9), or ant estipnated $16.05 \mathrm{~kg} / \mathrm{m} \times 5 \mathrm{~m}=\$ 0.3 \mathrm{~kg}$. The bulk volume of the material is estiunated to be $0.05 \mathrm{~m}^{3}$.

Total Volume for 3 Sinks

Total Weight for 3 Sinks

$$
\begin{aligned}
& =0.15 \mathrm{~m}^{3} \\
& =241 \mathrm{~kg}
\end{aligned}
$$

\section{D.6.6 Lead Vault}

The kead vault, located in the radioisotope nown within the user facility, is used for the stroge of radionelive chemicals. These chemicals are usuaily conlained in acid ar saline solutions, and are paciaged in giass vials and boules (Reference 1 , p. 7.31). The lead vautt is assumed to be contaminaled throughoul, and is removed as mixed waste. The lead vault is comprised of interlocking lead bricks (Reterence $\mathrm{t}, \mathrm{p} .9-18$ ) and is assumed to be $1.0 \mathrm{~m}$ deep $\times 1.5 \mathrm{~m}$ wide $\times 1.0 \mathrm{~m}$ high. autside dimensions, with 2 wall thickness assumed to be $0.1 \mathrm{~m}$. This makes the instide dintensions $0.8 \mathrm{~m}$ deep $x \mathrm{I} .3 \mathrm{~m}$ wide $x$ $0.8 \mathrm{~m}$ bigh. The lead vault is disassembled, brick-hy-brick. As the vault is disassembled, each brick is wel-wiped and allowed to dry. The dried bead bricks are bagged and placed in 208-fiter drums that are sent directly to radioactive hazardous mixed waste for encapsulation and dispesal. Wet-wiping is done using rags and brushes and a dilute aqueous solution with a smill amount of detergent.

Amount of Lead in the Vault

Volumet $1 \times 1.5 \times 1-0.8 \times 1.3 \times 0.8$

Weight: $0.668 \mathrm{~m}^{3} \times 11,300$

$$
\begin{aligned}
& =0.668 \mathrm{~m}^{3} \\
& =7,548 \mathrm{~kg}
\end{aligned}
$$

\section{D.6.7 Animal Cages}

The user facility has one animal cage that is assumed to be comprised of multiple-animal cages for study of animals that have been injected with radionuclides (Refertice 1, p. 7-31). The overall cage dimensions are assumed to be 1 m deep $\times 3$ m wide $x$ I $\mathrm{m}$ high. The cage is assumed to be divided into 2 cages high, 2 eages deep, 6 cages wide (total of 24 separated compartments), with tops that opera above each upper-row cage. The cage is assumed to be made of galvantzed steel wire $0.003175 \mathrm{~m}$ in diarneter on $0.0195-\mathrm{m}$ centers ( 52 wires/m) in a square pattern.

The cage is cut up into pieces, bagged, and placed efficiendy into 208-gallon drums for conpaction on-ste, then supercompaction off-site, followed by sending to a ditsposal facility os LL,W.

\section{Amount of Galventzed Steel in the Anlroal Cages}

Front, Middle, Back Walls: $3 \times 1.0 \mathrm{~m} \times 3.0 \mathrm{~m}$ Top, Midd]e. Bottom Walls: $3 \times 1.0 \mathrm{~m} \times 3.0 \mathrm{~m}$ Side Panels for all sub-cages: $71.0 \mathrm{~m} \times 1.0 \mathrm{~m}$

$$
\begin{aligned}
& =9 \mathrm{~m}^{2} \\
& =9 \mathrm{~m}^{2} \\
& =7 \mathrm{~m}^{2}
\end{aligned}
$$


Total Mesh Area:

There are $\$ 2$ witres for each meter of length, thus:

Tatal Length of Wire: $2 \times 25 \times 52$

Volume $(\pi / 4) \times 0.003175 \times 0.003175 \times 2600$

Weight: $8000 \times 0.0206$
$=25 \mathrm{~m}^{2}$

$$
\begin{aligned}
& =2600 \mathrm{~m} \\
& =0.0206 \mathrm{rn}^{3} \\
& =165 \mathrm{~kg}
\end{aligned}
$$

\section{D.6.8 Refrigerator}

The single reftigeralor in the user facillyy is used for storage of small quantities of labeled hydrocarbons to reduce chemical deterioration of the compounds (Reference 1. p. 7-3!). The resrigerator is postulated to be $0.6096 \mathrm{~m}$ wide $\mathrm{x} 0.6096 \mathrm{~m}$ deep x I.S24 in high.

The unit is assurred to be only mi|dly contaminated inside. But outside, the compressor, colls, fan, and other mechanisms are assumed to be contaninated to such a degree that it would not be reasonable to try to decontaminale it to levels required for unrestrieted use. Thus, the refrigarsios is assumed to be disposed of as radioactive LLW with only minimal decontamination. It is assumed that a subcontrackor will remove the freon on-file, after which the refrigerator will be vackumed, wiped and painled. It will then be cut up and bagged into 208-liter drums for on-site contwacting, then shipped off-site for supercompacting before disposal as LEW. Sectioning and bagging will be done to effectivoly use the space in the drums.

\section{Amount of Baterial in the Refrigerntor}

These calculation are based on gross characteristics of conventional refrigeralors. The unit contaitas the refrigeration cooling system (cojper, slexl, ohter metals), ssme framework (mikd steel), Flastic inner and outer walls separated by fiberglass insulation, with some plaslic trays, glass and mitd steel shelves inside. The owerall weight of the refigerator unit is assumed to be $68 \mathrm{~kg}$. The sectioned and pre-compacted volume of the unit is assumed to be the same as when whote, or $0.6096 \times 0.6096 \times 1.524=0.5663 \mathrm{~m}^{3}$.

\section{D.6.9 Filters}

In the user facility, one set of HEPA-plus-roughing filters is located at the exhaust of each of the five frute hoods and the ope glove box during normal operstion, for a total of six sets. No other HEPA or rowghing filters are used in the facility (Reference 1. p. 7-29 and p. 9-18). It is postulated that the filters had been replaced at the end of the ogerating period, and that they will last throughout the tocal decorrrissioning period. In addition, it is assurned that during the vacuuming activity of the components and the facility, a connnercial vacunum unit is leased that uses a roughing filter and a HEPA filter identical to those in the facility, and 2 sels of filters are used during vacouming, bringing the total to 8 sets. The filter rensoval is one of the tast activities ubidertaken during decommissioning-

Each inlter Is bagped with a plastic bag and sealed durithe its nemoval. The dimensions of the HEPA filters (Reference $t$. p. 9.18) are $0.2 \mathrm{~m}$ in diakneter $\times 0.2 \mathrm{~m} \mathrm{high;} \mathrm{the} \mathrm{roughing} \mathrm{filters} \mathrm{are} 0.2 \mathrm{~m}$ in dienretor $\times 0.1 \mathrm{~m}$ high. It is assoumed that the filters are comprised of shee-metal casing wilh pleated paper as the filter medium. It is postulated that the fFPA filters are bagged, placed in 208-liter dnums for on-site compaction, followed by shipneren off-site for supercompaction, before being packaged for disposal as LLW. 
Appendix D

\section{Amount of Matertals In the HEPA Filters}

The overall weight of each of the small, round HFPA filters is assumed to be $5 \mathrm{~kg}$. The estimated weight of the 8 HEPA filters is thus $40 \mathrm{~kg}$. The bulk (rectangular) volume of the 8 filters is $8 \times 0.2 \times 0.2 \times 0.2=0.064 \mathrm{~m}^{3}$.

\section{Amount of Materials in the Roughing Fitters}

The overall weight of each roughing niller is atsumed to be $2.5 \mathrm{~kg}$. The estimated weight of the 8 coughing filkers is thus $20 \mathrm{~kg}$. The bulk (reciangular) volume of the 8 roughing filters is $8 \times 0.2 \times 0.2 \times 0.1=0.032 \mathrm{~m}^{3}$.

\section{D.6.10 Washing Machine}

The user facility has one automatic washing macbine in the animal laboralory. The machine is used for some washing of laboratory clothing (Refereice 1, p. 7-31). The washing machine is positualed to be a conventional, hime-2se type, with dimensions of $0.65 \mathrm{~m}$ deep $\times 0.65 \mathrm{~m}$ wide $\times \mathrm{t} \mathrm{m}$ high .

It is assumed that the washing ouchine is contaringiced (imtennally from contarinaled clothing, and extemally in the mexhanical parts from slightly conlantinated dust and oil in the room) and is to be disposed of as radiosctive waste. The readtly-axcestible strfaces of the washing machine are vacuumed and wet-wiped, and ailowed to dry. The machine is cut up andior partially disassembled into pieces that fit efficiently into 208-liter forums. The waste is bagged belore being placed in dnums. The dnummed waste is compacted on-site, and then sent off-sile for superconpaction before being shipped to a disposal facifity as $\mathbf{L W}$.

\section{Ampount of Matestal in the Wasblng Machine}

This is baced on the gross characteristics of conventional washing machires. The machine will be comprised of the outer shelt, the wash tub, the electric motor, a water pump and the rest of the mechanical system, soleroid valves, electronic controls, and electrical equipment and wiring. The overall weight of the machine is assumed to be $68 \mathrm{~kg}$. The sectioned and pro-compacted volurne of the machine is assumed to be $2 / 3$ of the original volume when whole, or $2 / 3 \times(0.65 \times 0.65 \times 1.0)$ $=0.282 \mathrm{~m}^{\mathrm{m}}$.

\section{D.6.I1 Facility Ceiling}

The ceiling in the user facility consists of $80 \mathrm{mr}^{2}$ of suspended acoustically-treated fiberbood (Reference 1, p. 9-18), above which some piping and eiecrical wring are mownted. The fiberbsard comes in panels that are typicaliy $0.3 \times 0.3 \mathrm{~m}$ or $0.3 \mathrm{~m}$ $x .6$ us Each panel can be removed separately.

The fiberboart, postulated to be 0.0127 m thick, has a rought surface and many pores, which makes decontanination timpracticat. The ceilins panels are first vacuumed and painted to fix the contamination, then are nemoved for disposal as radioactive waste. The ceiling materials are broken up if necessary and bagged and inserted into 208-liter drums. The waste is then compacted on-site before iteing transported off-sitte for supercompaction and disposal as LLW. If the incineration option is used, the resultant ash is processed into a tnonolithic solid. The specific gravity of the fibeboand is assurwed to be 0.5 .

\section{Amount of Material in the Ceiling}

Volume: $80 \times 0.0127$

Procoratected Volumet $2 \times$ Volume

Weight: $500 \times$ Volune

$$
\begin{aligned}
& =1.016 \mathrm{~m}^{3} \\
& =2.0 \mathrm{~m}^{3} \\
& =508 \mathrm{~kg}
\end{aligned}
$$




\section{D.6.12 Facillity Walls}

There ace $130 \mathrm{mt}^{2}$ of plasterboard (postulated to be $0.015875 \mathrm{~m}$ thitek) in the user facility. The plasterboord is painted with latex enamel. It is assumed that the walls are to be doconlaminated to unrestricted levels to maintain the wall surficces and to keep from contaminaling the wall insulation and sunctural members behind the walls.

The walls are first vacuured, then wiped with wel rags and brushes. The decontamtinating sol ution, a diute aqueous detergent, is applied sparingly to minimize dripping. Afler wel-wiping, the walts are wiped with dry cags and allowed to dry completely. Finaliy, strippable paint is brushed or rolled on, allowed to dry in the room air, and then suripped off with the entrained contamination. Final hat spots are wel-wiped, or possibly spot-painted with strippable paint. Only materials used for decontanination are assumed to be bagged into 208-liter drums and disposed of as L.I.W.

\section{Amount of Waste Materials Resulting from Decontaminating the Walls}

The estimates developed in Reference 1, p. E-30, for the wash/wipe operations seem reasopable for the decontamination procedures used in the origiral study, but in this study, mxch less liquio decontaminating agent is used, and part of the decontamination is done with strippable paint. Thus, the amount of razs, brushes, and liqujd wastes hert is taken to be $1 / 3$ of that in the cuiginal stody, with adjustrnents for surface area. The estimates of waste materials from decoalanination and the subsequent waste treatment are given below. Disposition of the final wastes is discussed in each of the three subsets of waste cattegories below.

- 3 drains of wet rags, bnushes, contirninated gloves axd other clothing. These arte assumed to be wanpected on-site, seot off-site for supereompaction and LLW dispossl. If the incineration option is used, the waste is incinerated off-site, with the ashes fixed inio a monolithic solid and disposed of as LLW. Estimated weight of these wastes is $150 \mathrm{~kg}$ -

- 0.76 dnums of aqueous decontamination solutions (assumed to contain small ancounts of detergents) and vinse soltutions frorn wet-wiping. before solidification with an adsortetat naterial. Estimated weight of the waske before solidification is $125 \mathrm{~kg}$. The adsorbed wastes are sent directly for disposal as L.WW.

- 2 drums equivalent of removed strippable paint (assumed in this study). Estimated weight of the waste is $50 \mathrm{~kg}$. The waste is compacted on-sile, then sent to supercompacting off-site for disposal as L,LW.

\section{D.6.13 Facility Fioors}

The floors of the Uster facility consist of $80 \mathrm{~m}^{2}$ of asphalt tile (postulated to be $0.0015875 \mathrm{~m}$ thick) over concrete (Refenence 1, p. 7.29, p, 9.18). The floor is postulated to be first vacuumed and then pairted to fix the nemaining contarntnation. All tiks are postulated to be removed manually and packaged in plastic bags in 20g-liter druins compacted on-sile. supercompacted off-site, and then disposed of as $L L W$. The remining hot spots in the conlerete flooring are postulated to be cleaned by a small amournt of scabbling, followed by re-vacutaning the entime thoor surface. The concrete nuble and dust are postulated to be bagged and drummed for efficient use of the dirum space. The concrete rubble waste is compacted on-site. and the drums are sealed and disposed of as LWW.

\section{Amount of Radloactlve Waste Materinks Resplting from Removing the Fhor Tiles}

Volume: $80 \times 0.0015875$

Weight: $1100 \times 0.127$

$$
\begin{aligned}
& =0.127 \mathrm{mr}^{3} . \\
& =140 \mathrm{~kg}
\end{aligned}
$$


Appendix D

\section{Amount of Concrete Fooring Renoyed as Radiosedve Waste}

It is assumed that sone contamination will have penetrated through the cracks in the floot tile to the extenl that $10 \%$ of the underlying coacrete will be econiminated ta a depth of $0.0127 \mathrm{~m}$. The total amount of concrete rubble and dust removed as radiosctive waste is thus $80 \times 0.1 \times 0.0127=0.102 \mathrm{~m}^{3}$. Assuming the specific gravity is $60 \%$ of theoreal, the effeetive wolutre is $0.170 \mathrm{~m}$. Assuming a specific gravity of 2.5 , the weight of concrete dust and rubble is estimsted at $255 \mathrm{~kg}$.

\section{D.7 References}

1. E, S. Murphy, 1981. Technology, Safery and Costs of Decommitsioning Reference Nan-Fuel-Cycle Nuclear Facilities. NUREGLCR-1754, U.S. Nuclear Regulatory Commission Report by Pacific Northwest Laboralory, Richland, Washington.

2. "McMaster-Cart Stupply Company, Catalog 98," 1992. Mţaster-Cart Supply Company, Los Angeles, Califorsit. 


\section{Appendix $\mathbf{E}$}

Details of Decommissioning Reference Sites 


\section{Appendix E}

\section{Details of Decommissioning Reference Sites}

This appendix provides details 10 support the description of the decorntrissioning of sites presented in Chapter 7 . The reference siles include: (1) a site with a contaminated underground wasce line and bold-up tank, (2) a site with a contaminated ground surface, and (3) a tailings pile/evaporation pond containing uranium and thorium residues. The reference sites are described in Sectian 7.3 of NUREG/CR-17,54."

The deconmissioning allernatives for contaminated sites are: (1) site stablization foltowed by long-tern care and (2) remaval of the contaminated material to an approved shallow-land burial ground. Details of the technology and costs of these two alternatives are given in another report on the technology, safety, and costs of decommissioning a low-level waste burial ground '2" For convenience of reference, brief descriptions of several site stabilization optsons are given in Section G.1 of NUREGCR-1754.' ${ }^{\text {(? }}$

The following key bases and assurmptions are used for estimating labor requirements and costs:

(1) The deconumissioning of 2 site is performed by a contractor hifed by the owmer/operator of the site. Separate contractors might be hired for the sfie survey and tor the acuul decommissioning operabions. (In some instances, the owner/operator would perform his owin site survey.) The impact on decommissioning costs of uxilizing contractorn is discussed in Section D.1 of NUREGKCR-1754 II)

(2) To determine the total time required to decontrission a radioactively contaminated site, an estimate is made of the lime requited for effictent performance of the work by a posiulated work crew. This time estimale is then increased by $50 \%$ to provide for preparation and set-mp time, rest periods, etce (ancillary time).

(3) All matioactive wastes from the decommissioning of contaminaled sites are shipped by truek a distance of $800 \mathrm{~km}$ to a shallow-land burial ground.

(4) Transportation and waste disposal operations are subcontracted activities. The labor costs for the transportation and dispost of radioactive material are ipctuded in the totil costs of these iterts.

(S) Decommissioning includes the backfilling of a site from which wastes bave been exhurned and the restoration of the decommissioned sile by grading the site andfor planting grass of ocher appropriate vegetative cover. Costs of backrilling and site restoestion are included in the costs of decommissioning.

(6) If a site is $t$ be relezsed for unrestrixted public use, the finat decomrtissioning activity is a site survey to verify that nesidual kevels of radioactivity are below uncestricted release limits. Costs of this final radiation survey are included in the estimated costs of decontunissianing.

(7) Al costs tre in January 1998 dollars.

For eace in evaluating time and labor requirements for the decommissioning of sites, each decommissioning alternative is divided into a sequence of tasks or steps. For the site stabilization alternative, the steps are: 
- planning and preparation (including inital site survey)

- mobilization/demobilizalion

- site stabilization

- revegetation.

For the removal option, bese steps are:

- plaming and preparation (including initial stito survey)

- mobilizalton/demmbilization

- semove overturuen

- exhume and pactage contaminated material

- transpart and ditspose of contaminated material at a shallow-land burial grownd

- backfill and restore site

- firal site survey.

\section{E.1 Details of Decommissioning a Contaminated Underground Drain Line}

Time and laboc requirements and total cosis for the exhumation and disposal of a conkminated drain tise, hold-up tanth, and soil are presented in this section. The reference sinte is described in Section 7.3.1 of NUREG/CR-1754." Procedures for decomvissionting 1 drain line and holdup tank are given in Section G.2.J of that same document.

Details of estimaled time and labor requirements for removing a contaninaled dratn line and hold-up tank are presented in Table E.1. The radiological stavey that precedes site decommissionibs is performed by a work crew consiseling of a foceman and two bealth phystes techubicians from the site ownes's organization. A foreman and an equipment operator are required during exeavation of the trench. Exhuration and packaging of a 20-m-long, 0.1-m-dianxeter drain lino, 21.5 -m-dianeter, 2-听high cylindrical hold-up tank, and contanitsaled soil are performed by a crew that includes a foreman, an equiprent operaior, a pipefitter, and two techinicians. A health physics lechnician is presert during excavation and exhumation operations to rtoke radiological measurements. An equipmest operalor and a techmician backfitl and gasde the site after exhumation operations are completed. The final stie survey is performed by a foremen and wo bealuh plysies technicians.

Cost details for removing a contaminted drain line and hold-up tank are presented in Table E,2. The lotal costs of deconmuissioning the sjte is estimated to be about $\$ 126,000$. A contractor's fee is included in the tolat cosss as deseribed in Section D.1 of NUREG/CR-1754,"1) It is assumed that soil samules are sent to a commercial laboralory for analysis. Wasce management costs are based on a requirement for $7 \mathrm{~m}^{3}$ of $20 \mathrm{~g}$-liver dnums to contain the extumed material and contaninated soil. 


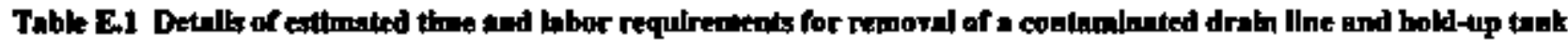

\begin{tabular}{|c|c|c|c|c|c|c|c|c|c|c|}
\hline \multirow[b]{2}{*}{ Qonnitin } & \multirow[b]{2}{*}{ The } & \multicolumn{7}{|c|}{ 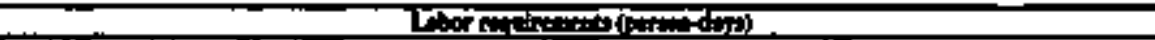 } & \multirow[b]{2}{*}{ 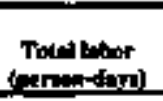 } & \multirow[b]{2}{*}{ 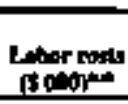 } \\
\hline & & 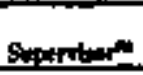 & 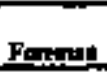 & $\begin{array}{l}\text { Parpanel } \\
\text { operster }\end{array}$ & Creflin:m & Techindan & 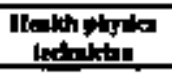 & Cont & & \\
\hline 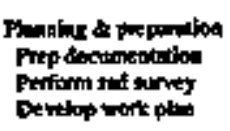 & $\mathbf{s}$ & 3 & 3 & - & - & - & 4 & 1 & is & 164 \\
\hline 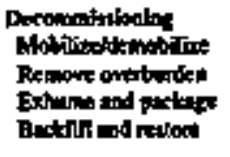 & $\begin{array}{c}10 \\
2 \\
15 \\
59 \\
1\end{array}$ & $\begin{array}{l}5 \\
1 \\
2.75 \\
0.5\end{array}$ & $\begin{array}{l}3 \\
2 \\
15 \\
5.5 \\
-\end{array}$ & $\begin{array}{l}10 \\
2 \\
1,5 \\
5.5 \\
1\end{array}$ & $\begin{array}{l}5.5 \\
\overline{5} \\
5.5 \\
+\end{array}$ & $\begin{array}{l}14 \\
2 \\
11 \\
1\end{array}$ & $\begin{array}{l}7 \\
\text { is } \\
\text { s5 } \\
2\end{array}$ & $\begin{array}{l}\ddot{ } \\
\ddot{z}\end{array}$ & $\begin{array}{l}504 \\
7 \\
525 \\
3575 \\
25\end{array}$ & $\begin{array}{r}27.39 \\
404 \\
2.72 \\
1918 \\
1.4\end{array}$ \\
\hline Fey & 2 & ل & $\frac{1}{16}$ & $=$ & $=$ & $=$ & 4 & $=$ & $\begin{array}{l}7 \\
75\end{array}$ & $\frac{259}{25,61}$ \\
\hline
\end{tabular}

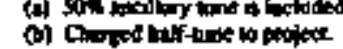

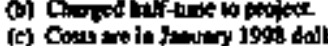

(d) 25\% cowiopocy int lnetoded. 
Table E.z Cost detalk for the removal of a contaminated draln Ine and hold-up imk

\begin{tabular}{|c|c|}
\hline Cost 1tem & Costes (S00) \\
\hline Labor & $35.6 \mathrm{I}$ \\
\hline Equipment & t5.75 \\
\hline Materials & $4 . \pi$ \\
\hline Soil analyses & 8,00 \\
\hline Contristor's feets & 3.68 \\
\hline \multicolumn{2}{|l|}{ Waste managememt } \\
\hline Packaging & 1.72 \\
\hline Transportation & 0.32 \\
\hline Disposal & 30.92 \\
\hline Sublotal & 100.74 \\
\hline $25 \%$ Contingexcy & 25.18 \\
\hline TotaI & 125.92 \\
\hline
\end{tabular}

(a) Cous we in Junary 1998 dollars Nember of figares stowe it for conpubational accurscy only.

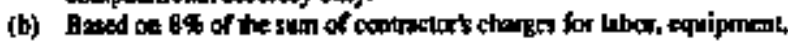
unerialy, anf pachiping

Only about 31\% of the total deconrmitsioning cosss are due to disposal charges, with most of this the to disposal of the holdup tank. Volume reduction of the hold-up ank via sectioning and supercompaction was not analyzed because of the lack of any signiftcant savings potential

\section{E.2 Details of Decommissioning a Contaminated Ground Surface}

Time and labor requitremeots and total costs for the removal of comianinaled soil from a reference site are evaluated in this section. The reference site is described in Section 7.3.2 of NUREG/CR-1754, (1) It is assumed to be comtaninated with radioactive residue from uranjum processing operations that was urxeked to the site from another locasion, dumped on the site, and used as fill material. Procedures for removing contaminared gound surface are given in Section G.3.1 of that same document.

Detajls of estimaled time and labor reguirements for removing a contaninated ground surface are presented in Table E.3. Radiological surveys are performed by a work crew consisting of a foreman and three health physics tecthicians fiom the site owner's organization. The coptratior's work crew for removal of approximstely $1000 \mathrm{~m}$ ' of contaginated soil includes a foreman, two exvipment operstiors, and two laborers. This crew is assisted by a health physics technician. Backfitling and grading of the sive (after soil removal operalions are completed) is aecomplished by a work crew that includes a foreman, two equipsnent opertors, and a laborer. 
Cost details for remoting a contaminated grawnd surface are presented in Table E.4. The total costs of decomymissioning the site is estimated to be about $\$ 1,396,066$. A contraterers fee is included in the total costs 25 described in Section D.1 of NUREGKCR-1754.'"'

Approximately $12 \%$ of the total decommissioaing cost is related to the initial and final site surveys. More than $74 \%$ of the cost of site surveys is associated with the analysis of wil samples. If adequate records exist, or if visual inspection of the site permits an area of contaminated soll to be localed with reasonable accuracy, it may be possibte to reduce the number of soit sartples collected for analysis. For example, if samples are collected from the centers of 20 m by 20 -nisurvey blocks instead of from the 10-m by $10-\mathrm{m}$ blocks used as $\mathrm{a}$ basis for the cost estimates of Table E.3, the number of soil sarmples and the cosi of sample analyses would decrase by a factor of 4.

Most of the tolal decomrnissioning cosl (approximutely 77\% of the tolal) is telated to the packaging, transportation, and disposal of the exhumed material. Packaging cost csuld be substantially reduced if the soil wero transporied to the shallowtand burial ground (LARW Envirseare facility) in piastic-lited dump trucks insteas of being packaged in B-25 metal cantainers. Transportution charges are not significantly affected by the type of vehicle used to transport the soil, but are affected by the distance from the contaminated site to the burtal ground. Disposal costs are not significanly affected by alternative modes of packaging or transport since these costs are direclly proportional to the volutne of soil requiring removal.

Disposal costs accolun for about $47 \%$ of the tocal decommissioning cost. No savings through volume reduction is possible since soil is nox compactible or combustible.

\section{E.3 Details of Decommissioning a Tailings Pile/Eraporation Pond}

Tyme and labor requirements and totsl costs for decomrntssioning a tailings pilefevaporstion pond by the athernatives of: (d) stabilization or (2) removal are evaluated in this section. Annuzal requirements and costs of lorg-term carte following stabilization are also evaluated.

The trilings piledevaporation pond is described in Section 73.3 of NUREG/CR-1754 (1) It is actually a settling pond that contains the residue from ore refinery operations in whteh tin slag is processed for the recovery of niobium and tantalum The residue from these operations conlains $0.2 \mathrm{wt} \mathrm{U}_{0} \mathrm{U}_{3} \mathrm{O}_{7}$ and $0.5 \mathrm{wt} \% \mathrm{ThO}_{2}$. The pond measures $100 \mathrm{~m}$ long by $50 \mathrm{~m}$ wide by 5 m deep with a 2.5 to I slope on each side. It contains $16,400 \mathrm{~mm}^{3}$ of glassy residae weighing $4+\mathrm{I} \times 10^{7} \mathrm{~kg}$.

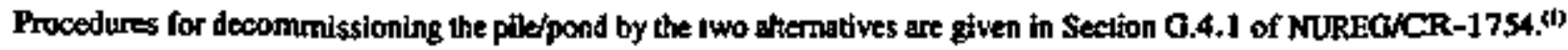

Dethils of estimated tirne and labor requirements for decomroissioning the pike/pond ere presented in Table E.S. Cast detalls are presented in Toble E.6.

\section{E.3.I Site Stabilization Alternative}

The asphatt for the thard cover over the tailings pile/evaporation pond is delivered to the site in tanker trucks. It is then transfered to a self-propelled soil stabitizer for application bo the surface of the pile/pood. The asphalt is applied at an assame rale of $50 \mathrm{liters} / \mathrm{m}^{2}$. Two days are required to complete this operation, which is performed by a wort crew consisting of a foreman, two equipmenl operaus, and two kaborers. 


\begin{tabular}{|c|c|c|c|c|c|c|c|c|c|c|}
\hline 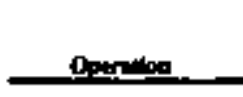 & $\min _{(x)}$ & 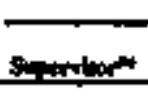 & Foning & Eو & 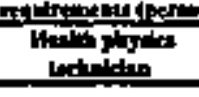 & 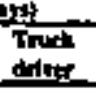 & 1estontr & ont & 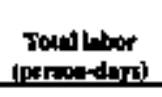 & 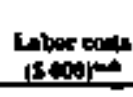 \\
\hline 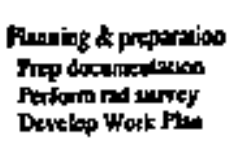 & 20 & 20 & 20 & - & yo & - & - & 3 & 75 & 274 \\
\hline 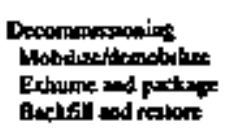 & $\begin{array}{l}17 \\
2 \\
12 \\
12\end{array}$ & $\begin{array}{l}13 \\
\text { is }\end{array}$ & $\begin{array}{r}17 \\
2 \\
12 \\
3\end{array}$ & $\begin{array}{r}34 \\
24 \\
24\end{array}$ & $\frac{12}{12}$ & $\frac{5}{9}$ & $\begin{array}{r}31 \\
4 \\
24 \\
3\end{array}$ & $\bar{\Sigma}$ & $\begin{array}{l}1115 \\
111 \\
72.5 \\
22.5\end{array}$ & $\begin{array}{l}5637 \\
582 \\
3802 \\
1153\end{array}$ \\
\hline لـ & 3 & 23s & 2 & $\Rightarrow$ & 18 & $\underline{\underline{9}}$ & $\stackrel{-}{.31}$ & $=$ & 2005 & $\begin{array}{l}318 \\
\text { 와요 }\end{array}$ \\
\hline
\end{tabular}

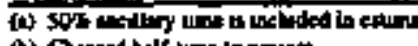

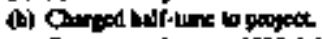

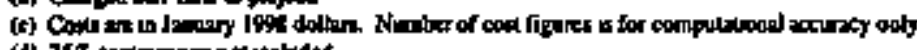

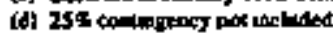


Tabje E.4 Cast details far the removal of a contaminated ground surface

\begin{tabular}{|c|c|}
\hline Cost llen & Cost $(\$(0) p)$ \\
\hline Labor & 91.99 \\
\hline Eqquipurent & 31.79 \\
\hline Materials & 15.51 \\
\hline Soil analyses & 96.00 \\
\hline Contractor's tee & 26.14 \\
\hline \multicolumn{2}{|l|}{ Waste managencent } \\
\hline Packaging & 297.13 \\
\hline Transportation & 88.46 \\
\hline Disprsal & 530.00 \\
\hline Sublotal & $1,1,7,02$ \\
\hline $25 \%$ Contingency & 279.26 \\
\hline Total & 2326.28 \\
\hline
\end{tabular}

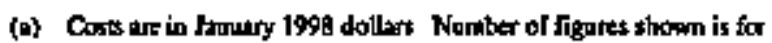
computallonal aceuraxy only.

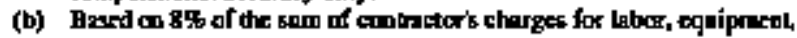
mutents, and pactaping.

The soil used as backfili over the hard cover is haukd to the sile in $10-\mathrm{m}^{3}$ domp tnucks. Approximately $5,600 \mathrm{~m}^{3}$ of soil is required. After the soil is in place, it is graded to the specified contours and compacteot with a roller. Six days are required to complete this operation, which is performed by a work crew that includes a foreman, 1wo equipment operators, eight truck drivers, and two laborers.

After the soil cover over the pife/pond is compucted and contours are established, the area is planted with Jass. Two equipment operalors and two laborens petform this eperation.

The total cose of site stabilization is estimated to be aboul $\$ 237,000$. About 35\% of this cost is for the asphalt and the soil used to establish cover over the tailings pile.

The total annual cost of long-termetre is estimated to be about $\$ 17,000$. Labor costs represent almosi $66 \%$ of this cost.

\section{E.3.2 Removal Alternative}

Two work crews, working s opposile ends of the pile/pond, are ermployed to remove and package the residue from the pile/pond. Each crew includes three equipment operators and thres labovers. A foremen supervises the work, and a health physies technician assists the erews. Bulldozers and frontend kaders are used to break up the residue and load it into B-25 


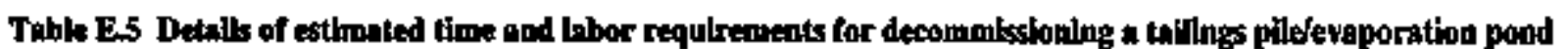

\begin{tabular}{|c|c|c|c|c|c|c|c|c|c|c|}
\hline \multirow[b]{2}{*}{ (an: } & \multirow[b]{2}{*}{ 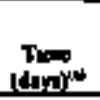 } & \multicolumn{7}{|c|}{ 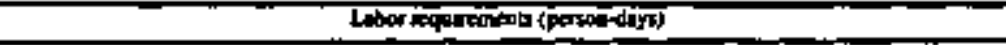 } & \multirow[b]{2}{*}{ 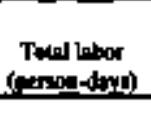 } & \multirow[b]{2}{*}{ 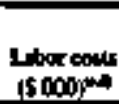 } \\
\hline & & Supqumpin & Fone? & Equphas & 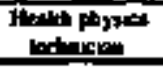 & 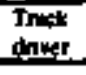 & Ltear & Q & & \\
\hline \multicolumn{11}{|l|}{ 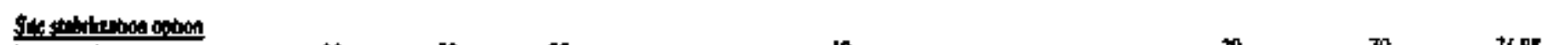 } \\
\hline 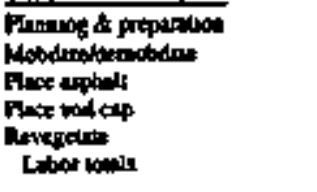 & $\begin{array}{r}25 \\
2 \\
2 \\
4 \\
\frac{3}{32}\end{array}$ & $\begin{array}{c}30 \\
1 \\
1 \\
3 \\
\frac{1}{15}\end{array}$ & $\begin{array}{l}20 \\
2 \\
2 \\
6 \\
\frac{7}{30}\end{array}$ & $\begin{array}{l}4 \\
4 \\
12 \\
\frac{4}{2}\end{array}$ & $\begin{array}{l}10 \\
\overline{2} \\
2 \\
\frac{2}{14}\end{array}$ & $\begin{array}{l}\ddot{-} \\
\ddot{40} \\
\overline{40}\end{array}$ & $\begin{array}{l}-7 \\
1 \\
12 \\
\frac{3}{2}\end{array}$ & $\begin{array}{l}20 \\
= \\
= \\
\frac{5}{20}\end{array}$ & $\begin{array}{l}70 \\
11 \\
13 \\
15 \\
5 \\
174\end{array}$ & $\begin{array}{r}2195 \\
585 \\
650 \\
3640 \\
259 \\
7133\end{array}$ \\
\hline \multicolumn{11}{|l|}{ 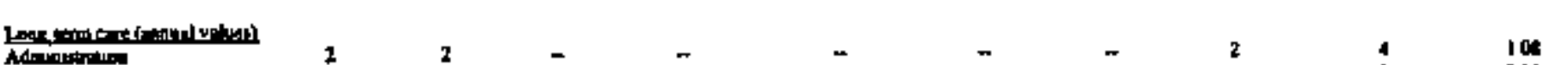 } \\
\hline Admostrates & 2 & 2 & $\bar{j}$ & 3 & $=$ & $=$ & $\ddot{j}$ & 2 & i & $\begin{array}{l}100 \\
3,10\end{array}$ \\
\hline 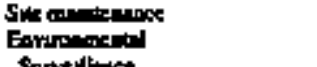 & 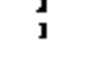 & $=$ & 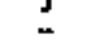 & - & 2 & 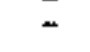 & - & - & 2 & 06 \\
\hline 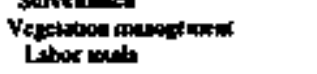 & $\frac{4}{10}$ & $\overline{\bar{z}}$ & $\frac{4}{3}$ & $\frac{\pi}{3}$ & $\bar{z}$ & $\bar{\Xi}$ & $\frac{B}{11}$ & $\frac{\pi}{2}$ & $\frac{12}{27}$ & $\frac{3 B}{873}$ \\
\hline 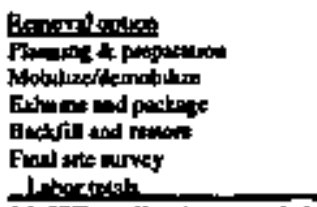 & $\begin{array}{r}20 \\
4 \\
90 \\
20 \\
\frac{3}{30} \\
\end{array}$ & $\begin{array}{l}20 \\
2 \\
45 \\
10 \\
\frac{25}{2515} \\
\end{array}$ & $\begin{array}{r}20 \\
1 \\
00 \\
20 \\
\frac{5}{39} \\
139\end{array}$ & $\begin{array}{l}24 \\
540 \\
40 \\
60 \\
0\end{array}$ & $\begin{array}{l}10 \\
\frac{10}{10} \\
\frac{10}{10}\end{array}$ & $\begin{array}{c}\bar{z} \\
100 \\
\overline{\overline{0}} \\
\end{array}$ & 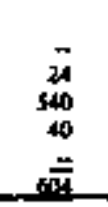 & $\begin{array}{l}20 \\
\bar{z} \\
\overline{20}\end{array}$ & $\begin{array}{r}20 \\
34 \\
1,305 \\
210 \\
115 \\
1,5355 \\
\end{array}$ & 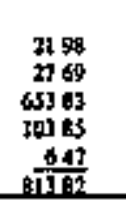 \\
\hline 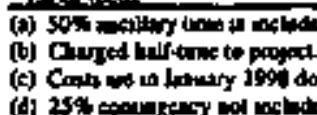 & 7 & & & & & & & & & \\
\hline
\end{tabular}


Tabie E.6 Cost detalis for the decommissionlng or a teilings pile/evaparation pond

\begin{tabular}{|c|c|c|c|}
\hline \multirow[b]{2}{*}{ Costliem } & \multirow[b]{2}{*}{ Silestabllization } & Cost. $(\$$ ofopin & \multirow[b]{2}{*}{ Pile reporal } \\
\hline & & $\begin{array}{l}\text { Long-term care } \\
\text { (anminal costs) }\end{array}$ & \\
\hline Lsbor & 73.35 & 8.73 & 813,8 \\
\hline Equlpoment & 21.25 & 1.80 & 98.9 \\
\hline Malterials & 74.50 & 0.75 & 179.2 \\
\hline Soil analyses & 10.00 & 2.00 & 96.0 \\
\hline Condractor's tee $\mathrm{e}^{\text {(1) }}$ & 10.86 & - & 452.0 \\
\hline \multicolumn{4}{|l|}{ Waste managentent } \\
\hline Packaging & - & - & $4,600.4$ \\
\hline Trensportation & - & - & 1.716 .0 \\
\hline Disposal & - & $=$ & 10.2820 \\
\hline Stubtotal & 189.95 & 13.28 & 18,2383 \\
\hline 25\% Conlingency & 4743 & 3,32 & 4.559 .6 \\
\hline Total & 237.44 & 16.60 & 22.797 .9 \\
\hline
\end{tabular}

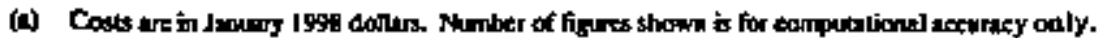

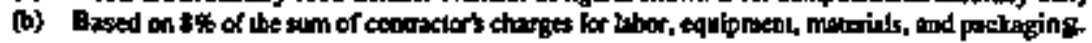

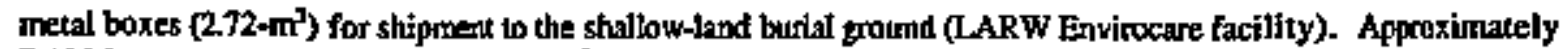
7,100 boxes are required for the $19,400 \mathrm{~m}^{3}$ of tilitins residue and conlaninated soil jemoved from the site. The boxes are shipped by trusk to the burial gromd. Shipknents are weight-limited, and are restricted to five boxes per flat-bed tratler. Therefore, 1,426 shipments mast be made to decormmission the site.

After the contarrinated msacerial is removed, soil is brought from off-site in 20 -m ${ }^{3}$-cupacity scraper-haulers lo fill the hole. The site is then graded and seeded with grass.

Approxirately 114 work days (23 weeks) are required to remove the contaminated material and restore the sile.

The total cost of the rerpoval option is estimated to be about $\$ 23$ million. Most of this cost (approximately $91 \%$ ) is associated with the waste management costs for disposal of the exhumed material. The waste management cost coutd be reduced by aboen \$4.0 million if the contaninaled material was transported to the shallow-Jand burial ground in plastic-tined 10-m'-capaelty dump trucks instead of being packaged in B-25 metal boxes. No savings through volume reduction is possible since soll is not corpactible or combitatibie. 
Appendix E

\section{E.4 References}

1. E. S. Murphy- 198!. Techinotogy, Safery, and Costs of Decommisstoning Reference Non-Fuet-Cyde Nuclear Facdities. NUREGRCR-1754, U.S. Nucleas Regulatory Commission report by Pacific Northwest Laboratory, Richland, Washīnglon.

2. E. S. Murphy and G. M. Holter. 1980. Technology, Safery, and Costs of Decommissioning a Reference Low-Level Waste Burial Gnound, NUREG/CR-0570, Vols. ! and 2, U.S. Nuclear Regulatory Commission Report by Pacific Nonhwest Laboralory, Richland, Washington. 


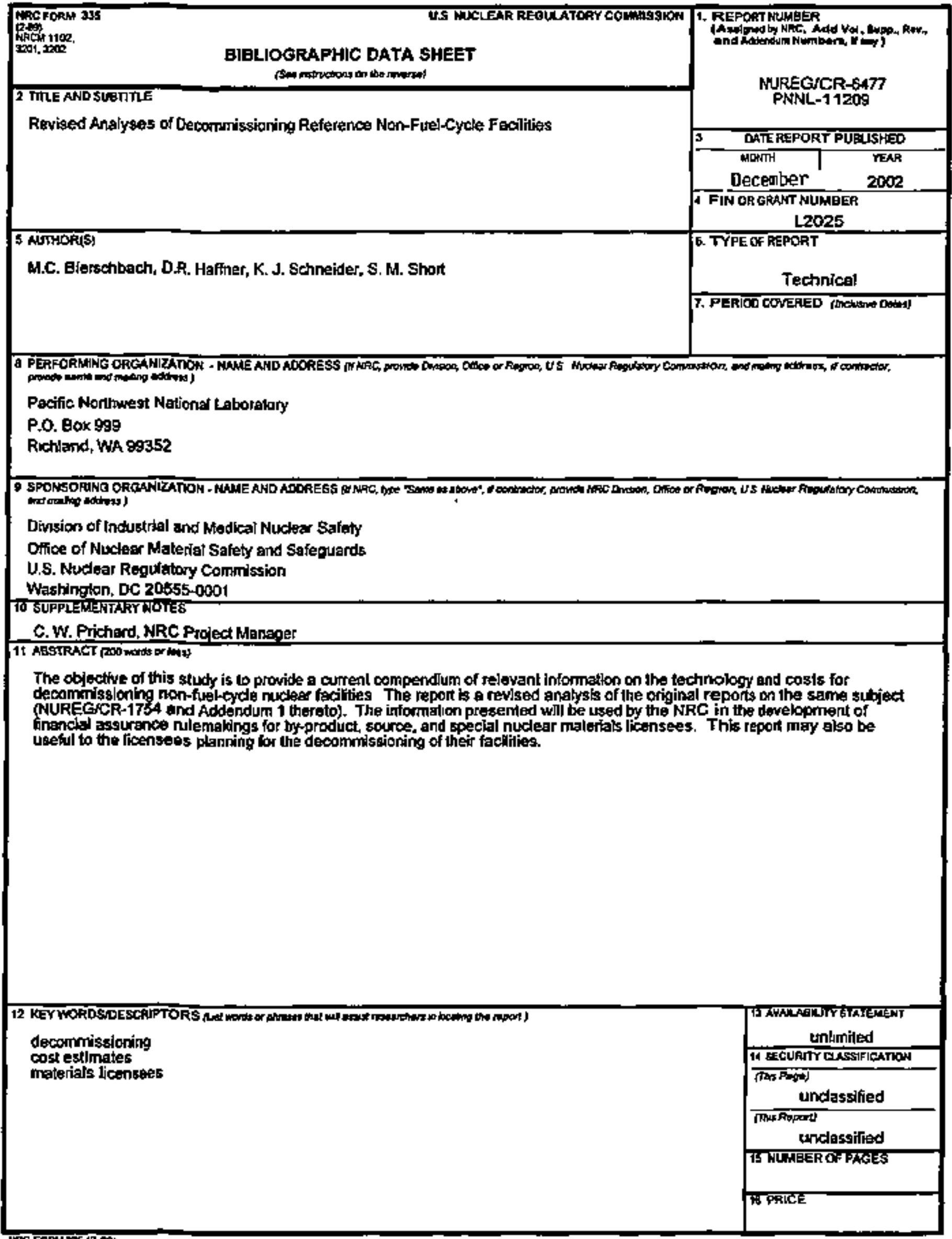



UNITED STATES

NUCLEAR REGULATORY COMMISSION

WASHINGTON, DC 20555-0001

OFFICIAL BUSINESS

PENALTY FOR PRNATE USE, $\$ 300$ 